\title{
HARMONISASI KONVENSI INTERNASIONAL PERLINDUNGAN HAK PEKERJA MIGRAN DENGAN UNDANG-UNDANG NOMOR 39 TAHUN 2004
}

HARMONIZATION OF INTERNATIONAL CONVENTION ON THE PROTECTION OF MIGRANT WORKERS RIGHTS WITH LAW NUMBER 39 YEAR 2004

Tesis

untuk memenuhi sebagian persyaratan mencapai derajat Magister

Program Studi Magister IImu Hukum

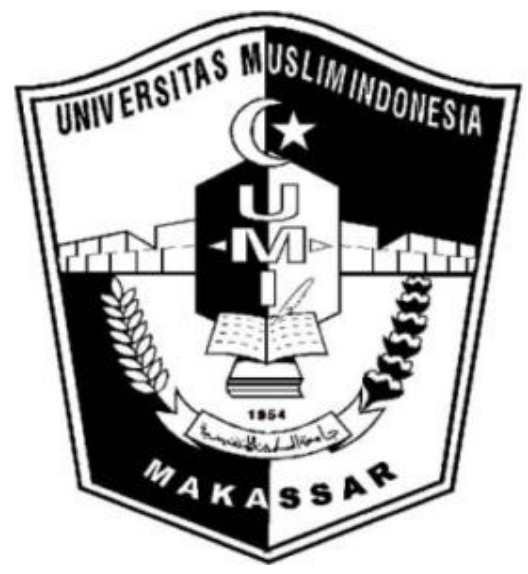

ACHMAD ZULFIKAR

0016.02 .42 .2015

PROGRAM PASCASARJANA UNIVERSITAS MUSLIM INDONESIA MAKASSAR 
遂) (图)

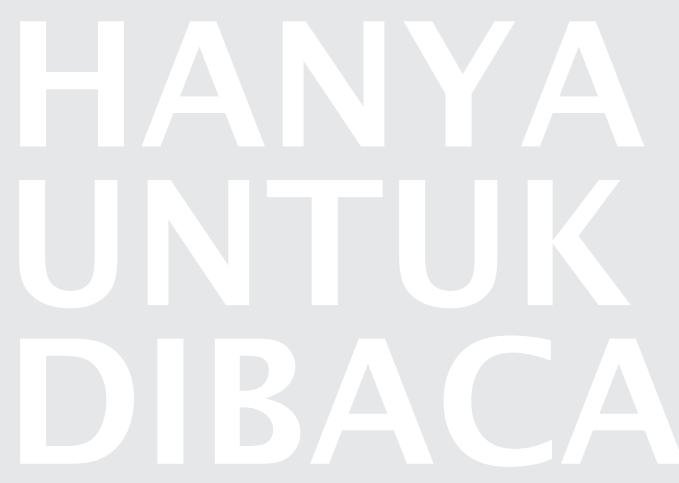




\section{Tesis}

HARMONISASI KONVENSI INTERNASIONAL PERLINDUNGAN HAK PEKERJA MIGRAN DENGAN UNDANG-UNDANG NOMOR 39 TAHUN 2004

\section{ACHMAD ZULFIKAR}

No. Induk Mahasiswa : 0016.02.42.2015

telah dipertahankan di hadapan Tim Penguji pada tanggal 05 Juli 2017

dan telah diperbaiki

\section{Komisi Pembimbing}

Ketua,
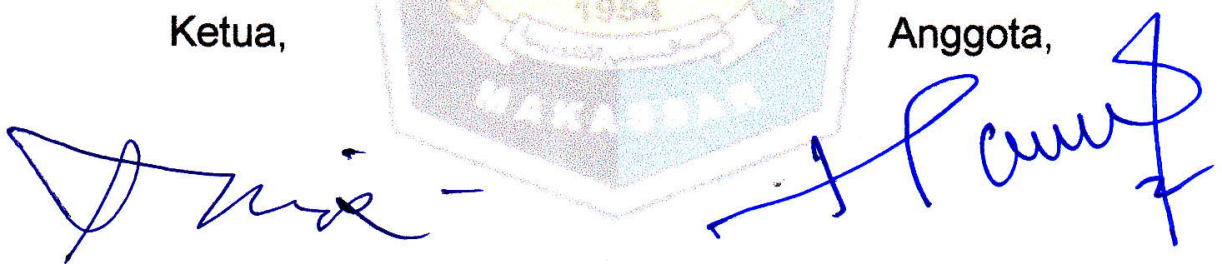

Prof Dr. Said Sampara, SH., MH. $\quad$ Dr. H. Hamza Baharuddin, SH., MH.

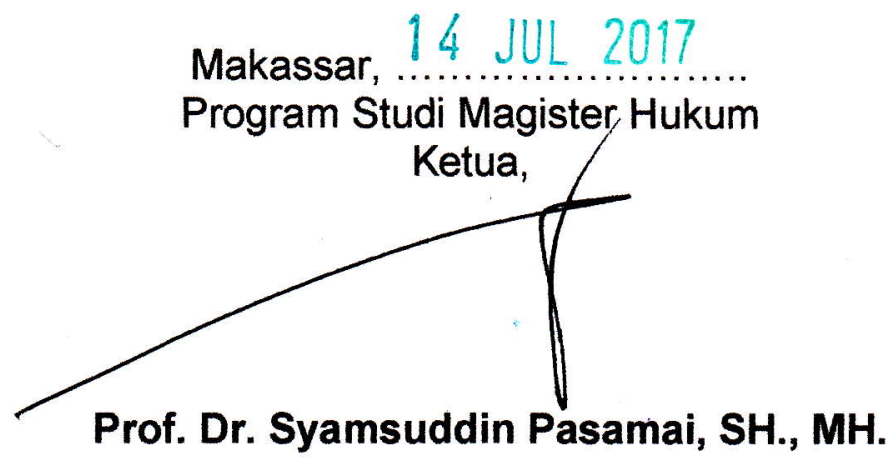




\section{HARMONISASI KONVENSI INTERNASIONAL PERLINDUNGAN HAK PEKERJA MIGRAN DENGAN UNDANG-UNDANG NOMOR 39 TAHUN 2004}

\section{ACHMAD ZULFIKAR}

No. Induk Mahasiswa : 0016.02.42.2015

telah dipertahankan di depan Dewan Penguji

pada tanggal 05 Juli 2017

dan dinyatakan telah memenuhi syarat

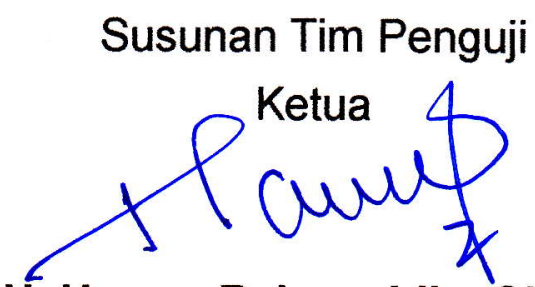

Dr. H. Hamza Baharuddin, SH., MH.

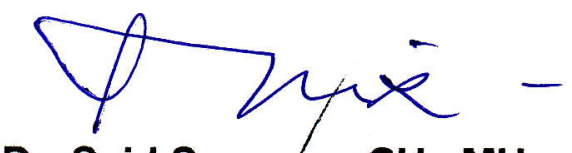

Prof. Dr. Said Sampara,SH., MH.

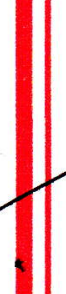

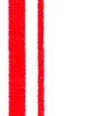

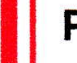

Prof. Dr. Syamsuddin Pasamai, SH.,MH.

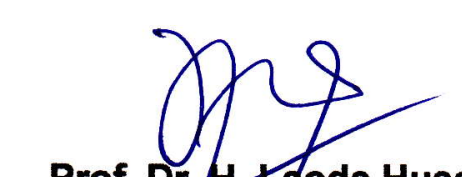

Prof. Dr. H. KKode Husen, SH.,MH.

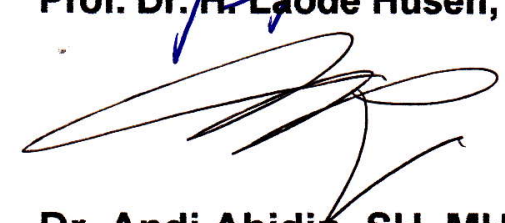

Dr. Andi Abidih, SH.,MH.

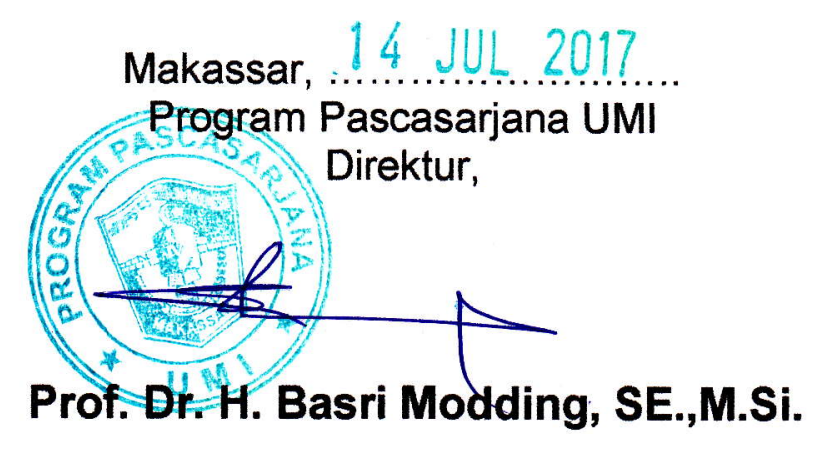




\section{KATA PENGANTAR}

\section{Assalamu alaikum wr wb.}

Puji dan syukur penulis panjatkan ke hadirat Allah SWT atas rahmat dan karunia-Nya, serta shalawat dan salam penulis haturkan kepada Nabi Muhammad SAW yang telah membawa ummatnya kepada era pencerahan dari zaman kejahiliahan.

Alhamdulillah, penulis haturkan atas terselesaikannya Tesis berjudul “Harmonisasi Konvensi Internasional Perlindungan Hak Pekerja Migran dengan Undang-Undang Nomor 39 Tahun 2004". Hadirnya tesis ini di tangan pembaca tentu melalui proses panjang mulai dari awal studi penulis hingga penyelesaian studi yang melibatkan banyak pihak.

Oleh karena itu, melalui kata pengantar ini penulis menyampaikan penghargaan yang setinggi-tingginya kepada Ibunda Sitti Rabiah yang telah memberikan dukungan materiil, moril dan spiritual kepada penulis sehingga kesempatan untuk melanjutkan studi di jenjang Magister untuk gelar yang kedua dapat penulis selesaikan. Selanjutnya kepada Ayahanda Baharuddin Nur, adik-adik Achmad Zulakbar, Achmad Chaedar dan Achmad Kautsar yang senantiasa memberi semangat. Penulis juga menyampaikan penghargaan dan terima kasih kepada:

1. Ibu Prof. Dr. Masrurah Mokhtar, M.A. selaku Rektor Universitas Muslim Indonesia

2. Bapak Prof. Dr. Basri Modding, S.E., M.Si. selaku Direktur Program Pascasarjana Universitas Muslim Indonesia 
3. Prof. Dr. Syamsuddin Pasamai, S.H., M.H. selaku KPS Magister IImu Hukum Universitas Muslim Indonesia

4. Prof. Dr. Said Sampara, S.H., M.H. selaku Pembimbing I dan Dr. Hamza Baharuddin, S.H., M.H. selaku Pembimbing II. Terima kasih atas arahan dan bimbingan dari Prof dan Bapak sehingga tesis ini dapat diselesaikan. Serta didikan selama menjadi mahasiswa di Magister IImu Hukum UMI.

5. Prof. Dr. H. La Ode Husen, S.H., M.H., Prof. Dr. Syamsuddin Pasamai, S.H., M.H. dan Dr. Andi Abidin, S.H., M.H. selaku Penguji. Terima kasih atas masukan-masukan yang diberikan.

6. Seluruh dosen pengajar di Magister Ilmu Hukum UMI, Prof. Dr. H. A. Muin Fahmal, S.H., M.H., Prof. Dr. H. A. La Ode Husen, S.H., M.H., Prof. Dr. Said Sampara, S.H., M.H., Prof. Dr. Syamsuddin Pasamai, S.H., M.H., Prof. Dr. H. Sufirman Rahman, S.H., M.H., Prof. Dr. H. Syahrir Mallongi, S.E., M.Si., Dr. Ahmad Fadil, S.H., M.H., Dr. H. Muhammad Syarief Nuh, S.H., M.H., Dr. H. Muh. Kamal Hidjaz, S.H., M.H., Dr. Andi Abidin R., S.H., M.H., Dr. Hamza Baharuddin, S.H., M.H., Dr. Syarifuddin, S.H., M.H., Dr. Hasan Kadir, S.H., M.H., Dr. Nurul Qamar, S.H., M.H., Dr. H, Askari Razak, S.H., M.H., Dr. Zainuddin, S.H., M.H., Dr. Ir. H. Amir Tjoneng, M.S., Dr. H. M. Saleh Suratmin, S.H., M.H., Dr. Hasbuddin Khalid, S.H., M.H., Dr. M. Dachran S. Busthami, S.H., M.H., Dr. Hj. Hikmawati Mustamin, S.H., M.H., Dr. Kamri Ahmad, S.H., M.Hum., Dr. Abdul Agis, S.H., M.H., Dr. 
H. Abdul Qahar, S.H., M.H. Terima kasih atas ilmu yang telah dibagikan Prof, Bapak dan Ibu, semoga berkah, bermanfaat dan menjadi amal jariah.

7. Direktur Penempatan dan Perlindungan Tenaga Kerja Luar Negeri, Kementerian Ketenagakerjaan Republik Indonesia dan Kepala Badan Nasional Penempatan dan Perlindungan Tenaga Kerja Indonesia (BNP2TKI) atas kesediaan Bapak untuk memberikan data dan informasi demi kelancaran penelitian ini.

8. Keluarga Magister Ilmu Hukum (MH 3) angkatan 42 / 2015 yang telah bersama menjalani perkuliahan: Muh. Arafah, Nasrah Hasmiati Attas, Erik Kadafin, Muhammad Ihsan Z, A. Alfatih Dindra Kasih, Musawira Isnainy, Afifah Dwi Hidayati, Dewi Arnita Sari, Nurmala Ramli, Muh. Furqan, Uci Fadillah, Mutmainnah, Andi Nadiah Ansyari, Harianto, Salahuddin Rusli, Hajarul Aswat, Zulkifli Amir, Wa Ode Murniati, Siti Zainab Yanlua, Moh. Ery Kusmiadi, Ruswan Latuconsina, Muh. Haerul Huluk, llyas dan Firman As'ad. Semoga tali persaudaran diantara kita tetap terjalin erat.

9. Keluarga Magister IImu Hukum (MH 8) Konsentrasi Hukum Tata Negara angkatan 42 / 2015 yang telah bersama menjalani perkuliahan: Muh. Arafah, Andi Rusdi Dirham, Musawira Isnainy, Muhammad Nawir, Hajarul Aswat, Muhammad Ichsan Agung, Darwin Rukua, Basri, Muhammad Alif Alfianto, Feprianto, Wiwin Apriadi, Tompo, Sitti Mardiyah Achmad dan Muhammad Sirul Haq. Semoga 
kekompakan kita senantiasa terjaga, walaupun dengan jumlah yang sedikit kita dapat berkontribusi bagi pembenahan ketatanegaraan di Indonesia.

Penulis mengucapkan terima kasih dan permohonan maaf kepada pihakpihak yang telah membantu dalam penyusunan tesis ini namun tidak dapat disampaikan satu per satu dalam kata pengantar ini. Semoga bantuan yang telah diberikan bernilai pahala di sisi Tuhan Yang Maha Esa.

Mengakhiri kata pengantar ini, penulis menyadari bahwa tesis ini masih perlu banyak masukan dan saran, maka dari itu penulis mengharapkan masukan dan saran konstruktif dari pembaca melalui email apa@kabarfikar.com. Semoga karya ini dapat berguna bagi semua pihak, pengembangan ilmu pengetahuan untuk kemajuan bangsa.

Wassalamu alaikum wr wb.

Makassar, 20 Ramadhan $1438 \mathrm{H}$ 15 Juni $2017 \mathrm{M}$

Achmad Zulfikar 


\section{ABSTRAK}

Achmad Zulfikar. Harmonisasi Konvensi Internasional Perlindungan Hak Pekerja Migran dengan Undang-Undang Nomor 39 Tahun 2004 (dibimbing oleh Said Sampara dan Hamza Baharuddin)

Penelitian ini bertujuan (1) menggambarkan dan menganalisis proses harmonisasi konvensi internasional perlindungan hak pekerja migran dengan Undang-Undang No. 39 Tahun 2004; dan (2) menggambarkan dan menganalisis proses adopsi substansi konvensi internasional perlindungan hak pekerja migran ke dalam Undang-Undang No. 39 Tahun 2004.

Metode yang digunakan dalam penelitian ini yakni penelitian hukum normatif dengan jenis penelitian terhadap taraf sinkronisasi vertikal dan horizontal. Jenis bahan dan sumber hukum dalam penelitian ini terdiri atas bahan hukum primer, sekunder dan tersier. Pengumpulan data dilakukan dengan studi kepustakaan (library research) dengan penguatan melalui wawancara (interview). Teknik analisis data dilakukan secara kualitatif dengan tiga alur kegiatan yakni reduksi data, penyajian data dan penarikan kesimpulan/verifikasi.

Hasil penelitian ini menujukkan bahwa: (1) harmonisasi konvensi internasional perlindungan hak pekerja migran dengan UU No. 39 Tahun 2004 dilakukan melalui proses transformasi yang mengacu pada kedudukan konvensi internasional dalam hukum nasional Indonesia; dan (2) substansi konvensi internasional perlindungan hak pekerja migran diadopsi melalui dua proses yakni proses politik melalui pembahasan RUU Perubahan UU No. 39 Tahun 2004 di DPR RI serta keterlibatan organisasi masyarakat sipil dan proses hukum dengan dirujuknya UU No. 6 Tahun 2012 pada RUU Perubahan UU No. 39 Tahun 2004 versi Mei 2016 dan diidentifikasi 7 temuan yang membandingkan RUU Perubahan dan UU pengesahan konvensi.

Kata Kunci: Harmonisasi, Konvensi Internasional, Hukum Nasional, Pekerja Migran, Tenaga Kerja Indonesia 


\section{ABSTRACT}

Achmad Zulfikar. Harmonization of International Convention on the Protection of Migrant Workers Rights with Law Number 39 Year 2004 (supervised by Said Sampara and Hamza Baharuddin)

This research aimed to (1) describe and analyze the harmonization process of international convention on the protection of migrant workers rights with Law No. 39 Year 2004; and (2) describes and analyze the process of adoption the substance of international convention on the protection of migrant workers rights into Law No. 39 Year 2004.

The method used in the research is normative legal research with the type of research on the level of vertical and horizontal synchronization. The types of materials and legal sources in this study consist of primary, secondary and tertiary. Data collection is done by library research with strengthening through interview. The data analysis technique is done qualitatively with three flow of activities such as: data reduction, data presentation and conclusion/verification.

The results showed that: (1) harmonization of international convention on the protection of the migrant workers rights with Law No. 39 Year 2004 is conducted through a transformation process that refers to the status of international convention in Indonesian national law; and (2) the substance of international convention on the protection of migrant workers rights is adopted through two processes. First, the political process through the discussion of Amendment Bill of Law No. 39 Year 2004 in the House of Representatives and the involvement of civil society organizations. Second, legal process with the referral of Law No. 6 Year 2012 on the Amendment Bill of Law No. 39 Year 2004 in May 2016 version and identification of 7 findings comparing the Amendment Bill and the adoption law of the convention.

Keywords: Harmonization, International Convention, National Law, Migrant Workers, Indonesian Migrant Workers 


\section{PERNYATAAN KEASLIAN TESIS}

Yang bertanda tangan di bawah ini:
Nama
: Achmad Zulfikar
NIM
: 0016.02.42.2015
Program Studi $\quad$ : Magister Ilmu Hukum
Menyatakan dengan sebenarnya bahwa tesis yang saya tulis ini sepanjang pengetahuan saya, di dalam naskah tesis ini tidak terdapat karya ilmiah yang pernah diajukan oleh orang lain untuk memperoleh gelar akademik di suatu perguruan tinggi, dan tidak terdapat karya atau pendapat yang pernah ditulis diterbitkan oleh orang lain, kecuali yang secara tertulis dikutip dalam naskah ini dan disebutkan dalam sumber kutipan dan daftar pustaka.

Jika ternyata di dalam naskah tesis ini dapat dibuktikan terdapat unsur-unsur jiplakan tesis, saya bersedia tesis dibatalkan serta diproses sesuai dengan peraturan perundang-undangan yang berlaku (UU No. 20 Tahun 2003, pasal 25 ayat 2 dan pasal 70)

Makassar, 5 Juli 2017

Yang menyatakan,

signed

Achmad Zulfikar 
Teks

Halaman

Halaman Judul ...................................................................... i

Halaman Persetujuan ................................................ ii

Kata Pengantar .................................................................. iii

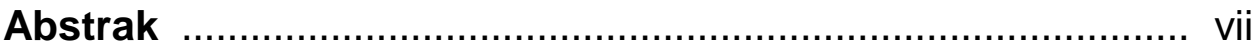

Pernyataan Keaslian Tesis ………………………........ ix

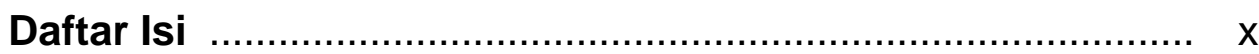

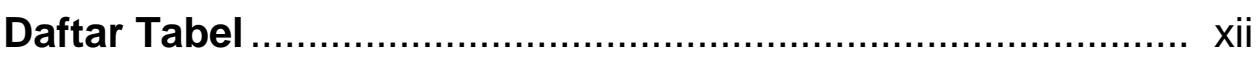

Daftar Bagan .................................................................

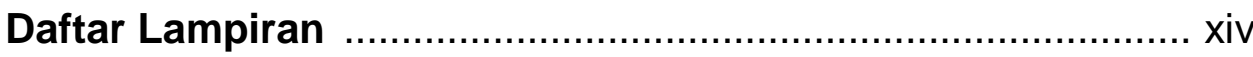

BAB I PENDAHULUAN

A. Latar Belakang Masalah .............................................. 1

B. Rumusan Masalah ...................................................... 10

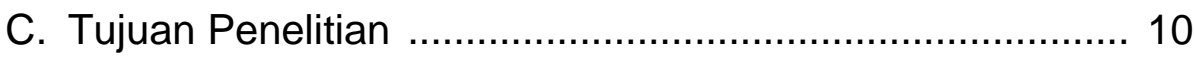

D. Manfaat Penelitian …...................................................... 11

\section{BAB II TINJAUAN PUSTAKA}

A. Landasan Teori

1. Teori Negara Hukum .............................................. 12

2. Konsep Harmonisasi Hukum .................................... 20

3. Konsep Perjanjian Internasional ................................ 30

4. Perjanjian Internasional sebagai Sumber Hukum Tata Negara ................................................ 33

5. Teori Hubungan Perjanjian Internasional dengan Hukum Nasional ................................................... 37

6. Konsep Pekerja Migran Indonesia ............................. 42

7. Pekerja Migran Indonesia dalam UU Nomor 39 Tahun 2004 ........................................ 44

8. Pekerja Migran dalam Hukum Internasional .............. 48

B. Kerangka Konseptual ................................................... 56 
C. Diagram Kerangka Konseptual .......................................... 58

D. Definisi Operasional ......................................................... 58

\section{BAB III METODE PENELITIAN}

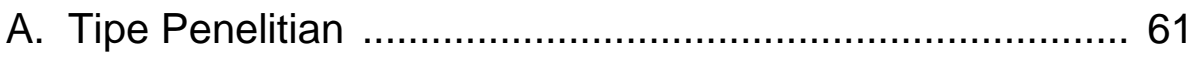
B. Jenis dan Sumber Bahan Hukum .................................... 62

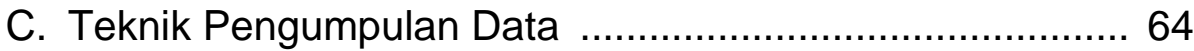

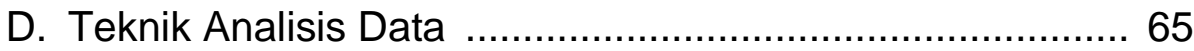

\section{BAB IV HASIL DAN PEMBAHASAN}

A. Harmonisasi Konvensi Internasional Perlindungan Hak Pekerja Migran dengan UU No. 39 Tahun 2004 ........ 70

1. Kedudukan Konvensi Internasional dalam Hukum Nasional Indonesia

2. Evaluasi Undang-Undang Nomor 39 Tahun 2004 dan Kajian terhadap Peraturan Perundang-Undangan Terkait

B. Adopsi Substansi Konvensi Internasional Perlindungan Hak Pekerja Migran ke dalam Undang-Undang No. 39 Tahun 2004

\section{BAB V PENUTUP}
A. Kesimpulan 249
B. Saran 250 
DAFTAR TABEL

Nomor Teks

Halaman

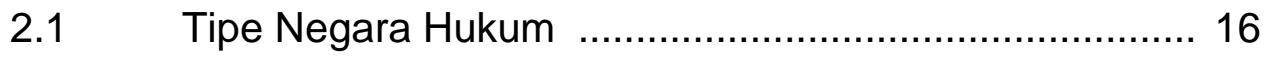

2.2 Perbandingan Hierarki Perundang-Undangan ............. 38

2.3 Perbandingan Monisme dan Dualisme ....................... 41

4.1 Perbandingan Monisme dan Dualisme ....................... 79

4.2 Perbandingan Paham Monisme - Dualisme ………...... 85

4.3 Perbandingan Hierarki Perundang-Undangan ............. 94

4.4 Pembagian Urusan Pemerintahan Konkuren antara Pemerintah Pusat dan Daerah Kabupaten/Kota ...........165

4.5 Kajian Peraturan Perundang-Undangan terkait Penempatan dan Perlindungan TKI di Luar Negeri dari Hukum Nasional

4.6 Kajian Peraturan Perundang-Undangan terkait Penempatan dan Perlindungan TKI di Luar Negeri dari Hukum Hasil Ratifikasi

4.7 Konvensi ILO tentang Prinsip Fundamental dan Hak di Tempat Kerja 193

4.8 Hak Pekerja Migran Sesuai Prinsip Fundamental ..........194

4.9 Hak Pekerja Migran Selama Proses Migrasi .................216

4.10 Tuntutan Revisi Berbasis Prinsip-Prinsip Konvensi ILO dan Konvensi Buruh Migran ..................219

4.11 Pokok-Pokok Pikiran RUU Perubahan UU Nomor 39 Tahun 2004

4.12 Adopsi Substansi Konvensi Internasional Perlindungan Hak Pekerja Migran dalam RUU Perubahan UU No. 39 Tahun 2004 


\section{DAFTAR BAGAN}

Nomor Teks

Halaman

2.1 Diagram Kerangka Konseptual Harmonisasi

Konvensi Internasional Perlindungan Hak

Pekerja Migran dengan Undang-Undang Nomor 39

Tahun 2004 58

3.1 Komponen-Komponen Analisis Data:

Model Interaktif

66 


\section{DAFTAR LAMPIRAN}

\section{Nomor Teks}

$1 \quad$ Undang-Undang Nomor 6 Tahun 2012 tentang Pengesahan International Convention on the Protection of the Rights of All Migrant Workers and Members of Their Families (Konvensi Internasional Mengenai Perlindungan Hak-Hak Seluruh Pekerja Migran dan Anggota Keluarganya)

Link: https://osf.io/7swuj/

$2 \quad$ Undang-Undang Nomor 39 Tahun 2004 tentang Penempatan dan Perlindungan Tenaga Kerja Indonesia di Luar Negeri

Link: https://osf.io/4yjwv/

3 Rancangan Undang-Undang (RUU) Perubahan Undang-Undang Nomor 39 Tahun 2004 (Rancangan Undang-Undang Republik Indonesia Nomor ... Tahun 2016 tentang Perlindungan Pekerja Migran Indonesia) Hasil Hotel Ciputra Mei 2016

Link: https://osf.io/ri2pb/ 


\section{BAB I}

\section{PENDAHULUAN}

\section{A. Latar Belakang Masalah}

Komitmen global terhadap migran semakin menguat. Perserikatan Bangsa-Bangsa (PBB) pada 19 September 2016 mengadakan Pertemuan Tingkat Tinggi (High Level Summit) untuk membahas besarnya pergerakan pengungsi dan migran dengan tujuan untuk mengajak negaranegara anggotanya bersama-sama lebih humanis dan terkoordinasi. Pertemuan ini merupakan pertama kalinya Sidang Umum PBB mengadakan pertemuan di tingkat Kepala Negara dan Pemerintahan sebagai upaya untuk menghasilkan cetak biru respon internasional terhadap pengungsi dan migran.

Pertemuan ini merupakan momentum untuk memperkuat kerjasama antar pemerintah untuk tata kelola migrasi internasional yang lebih baik dan merupakan kesempatan langka untuk menciptakan sistem yang responsif dan terencana untuk merespon besarnya pergerakan pengungsi dan migran. Dalam pertemuan ini sebanyak 193 negara anggota PBB menandatangani rencana aksi untuk menangani besarnya pergerakan pengungsi dan migrant yang dinamakan Deklarasi New York.

Deklarasi New York untuk Pengungsi dan Migran merupakan ekspresi itikad politik para pemimpin bangsa untuk menyelamatkan jiwa, melindungi hak-hak dan berbagi tanggungjawab dalam skala global. Dalam pertemuan ini, para pemimpin bangsa dari setiap negara akan mengimplementasikan komitmen ini. Pengungsi, migran dan mereka yang 
mendampinginya dan negara asal mereka dan komunitas-komunitas yang mendapatkan manfaat dari komitmen ini.

Deklarasi New York untuk Pengungsi dan Migran (New York Declaration for Refugees and Migrants) juga memuat komitmen bagi pekerja migran yakni:

"We call upon States that have not done so to consider ratifying, or acceding to, the International Convention on the Protection of the Rights of All Migrant Workers and Members of Their Families. We call also on States that have not done so to consider acceding to relevant International Labour Organization conventions, as appropriate. We note, in addition, that migrants enjoy rights and protection under various provisions of international law". (Part 3 about commitments for migrants Number 48$)^{1}$

Komitmen di atas menyerukan kepada seluruh negara yang belum meratifikasi atau mengaksesi Konvensi Internasional Perlindungan Hak Pekerja Migran untuk mempertimbangkan melakukannya. Demikian juga dengan negara-negara yang belum mengaksesi konvensi terkait dari ILO agar sedianya melakukan. Komitmen ini juga mengingatkan bahwa dengan melakukan seruan di atas, maka pekerja migran dapat menikmati hak-haknya dan perlindungan di bawah berbagai macam ketentuan dalam hukum internasional.

Komitmen terhadap pengungsi dan migran dilakukan sebagai respon atas meningkatnya pelaku migrasi internasional dari tahun ke tahun. Hal ini tentunya menggugah negara-negara di dunia untuk menaruh perhatian pada hal ini, baik sebagai negara pengirim, negara transit, negara penerima, maupun kombinasi dari ketiganya, termasuk Indonesia.

\footnotetext{
${ }^{1}$ United Nations, (2016), New York Declarations - UN Summit for Refugees and Migrants - http://refugeesmigrants.un.org/declaration, diakses pada 19 Desember 2016.
} 
Indonesia memiliki warga negara di luar negeri dengan jumlah yang signifikan. Kepala Desk Diaspora Kementerian Luar Negeri (Kemlu) Republik Indonesia, Wahid Supriyadi dalam sebuah wawancara yang dikutip dari Antara menyatakan bahwa saat ini orang Indonesia yang melakukan diaspora (migrasi internasional) diperkirakan mencapai 8-10 juta di seluruh dunia. ${ }^{2}$ Prakiraan ini termasuk TKI yang bekerja di luar negeri (pekerja migran Indonesia).

International Labour Organization (ILO) mengutip dari Badan Nasional Penempatan dan Perlindungan Tenaga Kerja Indonesia (BNP2TKI) dalam laporannya menyatakan selama periode 2006-2012, jumlah pekerja migran mencapai sekitar 4 juta. Sedangkan jumlah pekerja migran yang tidak memiliki dokumen resmi diperkirakan dua hingga empat kali lipat lebih besar. ${ }^{3}$

Merespon besarnya jumlah $\mathrm{PMI} / \mathrm{TKI}$ di luar negeri, maka pemerintah Indonesia pada tahun 2006 mengamanatkan pembentukan BNP2TKI. Badan ini merupakan badan yang dibentuk pemerintah untuk mengurus Tenaga Kerja Indonesia (TKI) di Luar Negeri atau saat ini disebut Pekerja Migran Indonesia berdasarkan UU No. 39 Tahun 2004 tentang Penempatan dan Perlindungan Tenaga Kerja Indonesia di Luar Negeri (PPTKILN) dan Peraturan Presiden No. 81 Tahun 2006 tentang BNP2TKI.

2 Antara News, (2013), Kemlu bentuk 11 Kelompok Kerja Kongres Diaspora http://www.antaranews.com/berita/384634/kemlu-bentuk-11-kelompok-kerja-kongresdiaspora, diakses pada 19 Desember 2016.

${ }^{3}$ International Labour Organization, (2013), Laporan ILO: 10 Tahun Menangani Migrasi Kerja di Indonesia - http://www.ilo.org/wcmsp5/groups/public/---asia/---ro-bangkok/---ilojakarta/documents/publication/wcms_213360.pdf, h. 3. 
BNP2TKI setiap tahun merilis data penempatan tenaga kerja Indonesia. Data penempatan TKI dalam 6 tahun terakhir, 586.802 orang pada $2011,494.609$ orang pada $2012,512.168$ orang pada $2013,429.872$ orang pada 2014, 275.736 orang pada 2015 dan hingga November 2016 sebanyak 212.900 orang. ${ }^{4}$ Data ini menunjukkan penempatan TKI dari tahun 2011 hingga 2016 mengalami penurunan yang signifikan. Walaupun pada tahun 2013 sempat mengalami kenaikan, tetapi penempatan TKI pada tahun 2015, jika dibandingkan tahun sebelumnya (2014) mengalami penurunan yang drastis. Kondisi ini terus berlanjut hingga November 2016.

Besarnya jumlah pekerja migran Indonesia/tenaga kerja Indonesia di luar negeri mendorong pemerintah untuk berbuat lebih dengan melakukan serangkaian upaya-upaya, termasuk dengan mengikatkan diri dalam hukum internasional. Hukum internasional yang dimaksud adalah Konvensi Internasional Protection of the Rights of All Migrant Workers and Members of their Families. Langkah-langkah Indonesia terlibat dalam konvensi tersebut diawali penandatanganan konvensi pada 22 September $2004^{5}$ oleh Menteri Luar Negeri Hassan Wirajuda di New York Amerika Serikat. Penandatanganan ini dilakukan pada kesempatan perjanjian tahunan PBB saat Sidang Majelis Umum PBB ke-59.

\footnotetext{
${ }^{4}$ BNP2TKI, (2016), Data Penempatan dan Perlindungan Tenaga Kerja Indonesia Periode 1 Januari-30 November 2016 - http://www.bnp2tki.go.id/uploads/data/data_09-122016_110656_Laporan_Pengolahan_Data_BNP2TKI_S.D_November_2016_.pdf ${ }^{5}$ Dewan Perwakilan Rakyat Republik Indonesia, (2012), Undang-Undang No. 6 Tahun 2012 - http://www.dpr.go.id/id/undang-undang/2012/6/uu/PENGESAHANINTERNATIONAL-CONVENTION-ON-THE-PROTECTION-OF-THE-RIGHTS-OF-ALLMIGRANT-WORKERS-AND-MEMBERS-OF-THEIR-FAMILIES-KONVENSIINTERNASIONAL-MENGENAI-PERLINDUNGAN-HAK-HAK-SELURUH-PEKERJAMIGRAN-DAN-ANGGOTA-KELUARGANYA
} 
Proses ratifikasi Konvensi sempat terhambat dikarenakan kondisi politik Indonesia yang sedang mengalami transisi kepemimpinan dari Presiden Megawati Soekarnoputri ke Presiden Susilo Bambang Yudhoyono. Setelah melewati satu periode Presiden Susilo Bambang Yudhoyono dan memasuki periode kedua, barulah Konvensi ini mengalami kemajuan dalam proses ratifikasinya. Kemajuan tersebut terjadi saat para pengambil kebijakan (stakeholder) pemerintah Indonesia yang terkait dengan bidang ketenagakerjaan seperti Komisi IX Dewan Perwakilan Rakyat RI sebagai perwakilan legislatif, serta Menteri Luar Negeri, Menteri Tenaga Kerja dan Transmigrasi, dan Menteri Hukum dan HAM sebagai perwakilan eksekutif mengadakan rapat kerja pada 9 April 2012. Akhirnya setelah rapat kerja, dicapai kata sepakat untuk membawa rancangan ratifikasi atas Konvensi Perlindungan Hak Pekerja Migran ini ke sidang pleno. Setelah melewati masa sidang, akhirnya pada 12 April 2012 Konvensi ini resmi menjadi Rancangan Undang-Undang. ${ }^{6}$

Selanjutnya pada 2 Mei 2012 RUU ini disahkan menjadi UU No. 6 Tahun 2012 tentang pengesahan International Convention on the Protection of The Rights Of All Migrant Workers and Members of Their Families (Konvensi Internasional mengenai Perlindungan Hak-Hak Seluruh Pekerja Migran dan Anggota Keluarganya) oleh Presiden Republik Indonesia Susilo Bambang Yudhoyono. Pasca diundangundangkannya, konvensi ini kemudian dilaporkan kepada Perserikatan

\footnotetext{
6 Human Right Watch, (2012), DPR Setujui Konvensi Buruh Migranhttp://www.hrw.org/id/news/2012/04/12/dpr-setujui-konvensi-buruh-migran, diakses pada 20 Desember 2016.
} 
Bangsa-Bangsa, sehingga dalam versi United Nations Treaty Collection ${ }^{7}$ mencantumkan bahwa diratifikasinya konvensi ini pada 31 Mei 2012. Proses yang dibutuhkan Konvensi ini dari proses penandatanganan hingga akhirnya diundangkan membutuhkan waktu tunggu selama 8 tahun (22 September 2004-2 Mei 2012).

Itikad politik hukum Indonesia dalam konvensi internasional perlindungan hak pekerja migran terlihat dari pernyataan Marty Natalegawa, Menteri Luar Negeri Republik Indonesia mewakili pemerintah pada rapat kerja Komisi IX pada pembicaraan tingkat I pembahasan RUU tentang pengesahan konvensi internasional mengenai perlindungan hakhak seluruh pekerja migran dan anggota keluarganya, sebagai berikut:

"Sebagaimana dimaklumi Indonesia telah menandatangani Konvensi ini pada tahun 2004, keputusan pemerintah Republik Indonesia untuk menandatangani Konvensi dimaksud merefleksikan komitmen kuat pemerintah terhadap pemajuan nilainilai hak azasi manusia termasuk didalamnya hak pekerja migran. Selain itu keputusan dimaksud juga mencerminkan prioritas Pemerintah RI untuk memberikan perlindungan terhadap hak-hak pekerja migran Indonesia, kedua hal tersebutlah juga yang mendorong Indonesia bertekat untuk meratifikasi Konvensi dimaksud guna menjadi bagian dari sistem hukum nasional Indonesia". ${ }^{8}$

Pernyataan di atas menunjukkan bahwa pemerintah Indonesia memiliki politik hukum yang kuat terhadap perlindungan hak-hak pekerja migran, hal tersebut mendasari Indonesia terlibat dalam penandatanganan

\footnotetext{
${ }^{7}$ United Nations Treaty Collection, (2003), International Convention on the Protection of the Rights of All Migrant Workers and Members of their Familieshttp://treaties.un.org/Pages/ViewDetails.aspx?mtdsg_no=IV-13\&chapter=4\&lang=en

${ }^{8}$ Dewan Perwakilan Rakyat Republik Indonesia, (2012), Risalah Rapat Kerja Komisi IX pada Pembicaraan Tingkat I Pembahasan RUU tentang Pengesahan Konvensi Internasional mengenai Perlindungan Hak-Hak Seluruh Pekerja Migran dan Anggota Keluarganya, h. 4.
} 
Konvensi pada tahun 2004. Marty Natalegawa melanjutkan penjelasan mengenai proses pembuatan keputusan, sehingga konvensi ini diratifikasi:

"Proses persiapan bagi ratifikasi Konvensi telah melalui proses yang seksama dan karenanya memakan waktu yang relatif panjang, sungguh keputusan untuk meratifikasi Konvensi merupakan bagian dari perwujudan tanggung jawab negara untuk meningkatkan perlindungan terhadap tenaga kerja migran Indonesia. Langkah ini juga menunjukkan kepedulian dan keberpihakan seluruh elemen bangsa untuk terus memajukan dan melindungi nilai-nilai HAM di tahah air dan di tingkat global utamanya dalam memperkuat kerangka perlindungan bagi pekerja migran Indonesia dan anggota keluarga mereka". 9

Pernyataan di atas menunjukkan bahwa waktu tunggu selama 8 tahun sejak penandatanganan disadari sebagai waktu yang relatif panjang untuk menunjukkan tanggung jawab pemerintah terhadap perlindungan terhadap pekerja migran Indonesia.

Keputusan pemerintah untuk meratifikasi konvensi ini dilatarbelakangi tiga hal utama antara lain: (1) mempertegas komitmen Indonesia bagi peningkatan perlindungan, penghormatan, pemajuan, dan pemenuhan hak asasi manusia terutama hak asasi seluruh pekerja migran dan anggota keluarganya; (2) memperkuat landasan hukum bagi kebijakan nasional dalam meningkatkan sistem perlindungan, pengormatan, pemajuan, dan pemenuhan hak-hak asazi tenaga kerja migran dan anggota keluarganya; dan (3) memperkuat mekanisme perlindungan tenaga kerja migran dan penataan manajemen migrasi baik bilateral maupun multilateral, agar pekerja migran Indonesia dapat menikmati perlindungan dan haknya dengan lebih baik mulai dari tahapan pra-penempatan, masa transit, selama bekerja di luar negeri, maupun

${ }^{9}$ Ibid. 
purna penempatan. Hal ini disampaikan Marty Natalegawa sebagai perwakilan pemerintah dalam Rapat Kerja Komisi IX. ${ }^{10}$

Perjalanan panjang pemerintah dalam mewujudkan tanggung jawab negara terhadap pekerja migran Indonesia yang merupakan warga negaranya serta pertimbangan yang melatarbelakangi sehingga Konvensi tersebut diratifikasi turut disertai dengan konsekuensi yang lahir dari keputusan yang diambil pemerintah ini. Hal ini telah disadari pemerintah dan disampaikan oleh Marty Natalegawa sebagai perwakilan pemerintah dalam rapat kerja dengan komisi IX, sebagai berikut:

"Ratifikasi konvensi ini tentunya akan melahirkan sebuah kewajiban antara lain untuk melakukan upaya harmonisasi hukum nasional terutama yang berkaitan dengan penempatan dan perlindungan tenaga kerja migran Indonesia dan keluarganya, agar sesuai dengan standar hak azasi pekerja migran sebagaimana diatur dalam konvensi. Isi konvensi ini akan menjadi acuan untuk menciptakan dan merevisi berbagai peraturan perundangundangan yang menyangkut tenaga kerja migran Indonesia". ${ }^{11}$

Pernyataan di atas menunjukkan bahwa pemerintah telah menyadari konsekuensi untuk melakukan harmonisasi hukum nasional. Berdasarkan penelusuran awal peneliti, LSM Migrant Care mencatat bahwa revisi UU No. 39 Tahun 2004 telah masuk sebagai agenda program legislasi nasional (prolegnas) DPR RI pada November 2010, kemudian 12 April 2012 Konvensi Internasional Perlindungan Hak Pekerja Migran disahkan dalam rapat paripurna oleh DPR RI, dilanjutkan pada 23 Mei 2012 dilakukan pengharmonisasian, pembulatan dan pemantapan konsepsi Rancangan Undang-Undang Perlindungan Pekerja Indonesia di Luar Negeri (PPILN), akhirnya 5 Juli 2012 DPR RI mengadakan sidang

${ }_{11}^{10}$ lbid. h. 6.

${ }^{11}$ lbid. 
paripurna DPR RI mengesahkan RUU revisi UU PPILN menjadi RUU inisiatif DPR RI. Proses terus berlanjut hingga 8 April 2013, rapat antara panitia kerja (panja) RUU PPILN dengan pemerintah membahas judul RUU tetapi tidak ada kesepakatan. Revisi undang-undang ini belum disepakati hingga berakhirnya masa bakti DPR RI 2009-2014. Setelah pemilihan legislatif tahun 2014 dan terpilihnya anggota DPR RI masa bakti 2014-2019 belum ada lagi pembahasan RUU antara pemerintah dan dewan.

Komitmen global terhadap pengungsi dan migran, termasuk pekerja migran merupakan momentum bagi Indonesia untuk meningkatkan posisi tawar (bargaining position) terhadap negara tujuan kerja. Di samping itu juga membenahi Undang-Undang Nomor 39 Tahun 2004 tentang Penempatan dan Perlindungan Tenaga Kerja Indonesia di Luar Negeri (PPTKILN) dengan menyelaraskannya dengan standar internasional sebagaimana tercantum dalam Konvensi yang telah diratifikasi dalam UU No. 6 Tahun 2012 tentang pengesahan International Convention on the Protection of The Rights Of All Migrant Workers and Members of Their Families (Konvensi Internasional mengenai Perlindungan Hak-Hak Seluruh Pekerja Migran dan Anggota Keluarganya).

Dinamika politik hukum yang tergambar dalam proses ratifikasi konvensi internasional perlindungan hak pekerja migran menunjukkan komitmen pemerintah Indonesia untuk mengemban tanggung jawab dalam melindungi pekerja migran Indonesia. Sehingga Konvensi 
Internasional Perlindungan Hak Pekerja Migran yang sudah diratifikasi oleh pemerintah Indonesia diharapkan dapat memperkuat instrumen hukum nasional yang sudah ada. Sebagaimana telah dinyatakan oleh perwakilan pemerintah dalam pembahasan Konvensi ini bahwa ratifikasi konvensi ini berimplikasi terhadap kewajiban negara untuk melakukan upaya harmonisasi hukum nasional. Hal ini menarik minat peneliti untuk mendalami lebih lanjut mengenai: Harmonisasi Konvensi Internasional Perlindungan Hak Pekerja Migran dengan Undang-Undang Nomor 39 Tahun 2004.

\section{B. Rumusan Masalah}

Berdasarkan uraian latar belakang masalah di atas, maka rumusan masalah penelitian sebagai berikut:

1. Bagaimanakah harmonisasi konvensi internasional perlindungan hak pekerja migran dengan Undang-Undang No. 39 Tahun 2004?

2. Bagaimanakah substansi konvensi internasional perlindungan hak pekerja migran diadopsi ke dalam Undang-Undang No. 39 Tahun $2004 ?$

\section{Tujuan Penelitian}

Melalui penulisan tesis ini beberapa tujuan yang ingin dicapai oleh penulis, sebagai berikut:

1. Menggambarkan dan menganalisis proses harmonisasi konvensi internasional perlindungan hak pekerja migran dengan UndangUndang No. 39 Tahun 2004.

2. Menggambarkan dan menganalisis proses adopsi substansi konvensi internasional perlindungan hak pekerja migran ke dalam UndangUndang No. 39 Tahun 2004. 


\section{Manfaat Penelitian}

\section{Manfaat Akademik}

a. Menunjukkan secara ilmiah proses harmonisasi konvensi internasional perlindungan hak pekerja migran dengan Undang-Undang No. 39 Tahun 2004 dan proses adopsi substansinya.

b. Memperkaya kajian hukum internasional dan hubungannya dengan hukum tata negara Indonesia terkait pekerja migran Indonesia untuk pengembangan keilmuan.

\section{Manfaat Praktis}

a. Memberikan bahan rujukan kepada stakeholder untuk mengambil kebijakan yang efektif dalam perlindungan pekerja migran Indonesia berdasarkan hukum nasional dan internasional.

b. Memberikan pemahaman kepada masyarakat mengenai status perjanjian internasional dengan hukum nasional Indonesia terkait perlindungan pekerja migran Indonesia. 


\section{BAB II}

\section{TINJAUAN PUSTAKA}

Bab ini membahas tiga bagian antara lain: landasan teori, kerangka konseptual dan definisi operasional. Konsep dan teori yang diuraikan pada landasan teori antara lain: teori negara hukum, konsep harmonisasi hukum, konsep perjanjian internasional, perjanjian internasional sebagai sumber hukum tata negara, teori hubungan perjanjian internasional dengan hukum nasional, konsep pekerja migran Indonesia, pekerja migran Indonesia dalam UU No. 39 Tahun 2004 dan pekerja migran dalam hukum internasional.

\section{A. Landasan Teori}

\section{Teori Negara Hukum}

Negara hukum dalam sistem ketatanegaraan Indonesia telah ditegaskan dalam Pasal 1 ayat (3) UUD NRI 1945 yang menyatakan bahwa "Negara Indonesia adalah negara hukum" yang ditetapkan pada tanggal 9 November 2001. (Jimly Asshiddiqie dalam La Ode Husen, 2009:1 ${ }^{1}$ Negara hukum dibagi ke dalam lima tipe yakni: Rechsstaat, the Rule of Law, Socialist Legality, Nomokrasi Islam dan Negara Hukum (Indonesia). Masing-masing dari kelima tipe negara hukum ini memiliki karakteristiknya tersendiri. $^{2}$

Menurut Hadjon dalam La Ode Husen, rechtsstaat lahir sebagai reaksi menentang absolutisme, karena itu sifatnya revolusioner dan bertumpu pada sistem hukum kontinental atau yang disebut civil law.

1 La Ode Husen, (2009). Negara Hukum, Demokrasi dan Pemisahan Kekuasaan, Makassar: Umitoha Ukhuwah Grafika, h. 1.

2 lbid. 
Jelas berbeda dengan istilah dalam paham the rule of law, yang perkembangannya terjadi secara evolusioner dan bertumpu pada paham atau sistem hukum common law. Namun demikian dalam perkembangannya perbedaan latar belakang itu tidak perlu dipertentangkan lagi, dikarenakan menuju pada sasaran yang sama yaitu bertujuan untuk mewujudkan perlindungan terhadap hak-hak asasi manusia. $^{3}$

Rechsstaat dikembangkan oleh ahli hukum Eropa seperti Immanuel Kant dan Friedrich Julius Stahl. Negara hukum menurut Kant dalam arti sempit yakni menempatkan fungsi recht pada staat, hanya sebagai alat perlindungan hak-hak individu dan kekuasaan negara diartikan secara pasif, yang bertugas sebagai pemelihara ketertiban dan keamanan masyarakat. ${ }^{4}$ Selanjutnya, penyempurnaan dilakukan oleh Frederich Julius Stahl dalam karyanya berjudul Philosophie des Rechts, terbit pada tahun 1878 , Stahl mengetengahkan paham negara hukum formal dengan unsur-unsur utamanya yaitu: mengakui dan melindungi hak-hak asasi manusia; (a) untuk melindungi terhadap hak-hak asasi tersebut maka penyelenggara negara harus berdasarkan atas teori trias politica; (b) dalam menjalankan tugasnya, pemerintah harus berdasarkan atas Undang-Undang (wetmatigbestuur); (c) jika dalam menjalankan tugasnya berdasarkan Undang-Undang, pemerintah masih melanggar hak asasi (campur tangan pemerintah dalam kehidupan pribadi seseorang), maka

\footnotetext{
${ }^{3}$ Ibid. h. 4.

${ }^{4}$ Philipus M. Hadjon, (1987), Perlindungan Hukum Bagi Rakyat di Indonesia, Surabaya: Bina llmu, hh. 76-82.
} 
ada pengadilan administrasi yang menyelesaikannya. (Padmo Wahjono dalam La Ode Husen, 2009:15) ${ }^{5}$

Konsep negara hukum dalam paham rechtsstaat pada abad ke-20 telah mengalami penyempurnaan yang mendapat perhatian dari para pemikir di Eropa. Salah satu diantaranya adalah Paul Scholten, dalam karyanya Velzamelde Geschriften, mengemukakan paham negara hukum dibedakan antara asas dan aspek negara hukum. Unsur yang dianggap penting dinamakannya dengan "asas", unsur yang merupakan turunannya disebut "aspek". Asas negara hukum menurut paham Scholten adalah (a) ada hak warga terhadap negara, yang mengandung dua aspek: pertama, hak individu pada prinsipnya berada di luar wewenang negara; kedua, pembatasan terhadap hak tersebut hanyalah dengan ketentuan UndangUndang, berupa peraturan yang berlaku umum; (b) adanya pemisahan kekuasaan. ${ }^{6}$

Menurut A. V. Dicey dalam Hadjon, the rule of law memiliki tiga ciri yaitu: (1) supremasi hukum dari regular law untuk menentang pengaruh dari arbitrary power dan meniadakan kesewenang-wenangan, prerogative atau discretionary authority yang luas dari pemerintah; (2) persamaan di hadapan hukum dari semua golongan kepada ordinary law of the land yang dilaksanakan oleh ordinary court. Ini berarti bahwa tidak ada orang yang berada di atas hukum, baik pejabat maupun warga negara biasa berkewajiban menaati hukum yang sama dan (3) konstitusi adalah hasil dari the ordinary law of the land, bahwa hukum konstitusi bukanlah

\footnotetext{
${ }^{5}$ La Ode Husen, op. cit., h. 15.

${ }^{6}$ Ibid. h. 16.
} 
sumber tetapi merupakan konsekuensi dari hak-hak individu yang dirumuskan dan ditegaskan oleh peradilan, singkatnya, prinsip-prinsip hukum privat melalui tindakan peradilan dan parlemen sedemikian diperluas sehingga membatasi posisi Crown dan pejabat-pejabatnya. ${ }^{7}$

Selain paham rechtsstaat dan the rule of law, juga dikenal konsep social legality yang bersumber pada paham komunis, dengan menempatkan hukum sebagai alat untuk mewujudkan sosialisme dengan mengabaikan hak-hak individu. Hak-hak individu menyatu dalam tujuan sosialisme yang mengutamakan kolektivisme di atas kepentingan individu. (Mohammad Tahir Azhar dalam La Ode Husen, 2009:4) Oleh karena itu, selain istilah rechtsstaat atau the rule of law di negara-negara yang menganut paham ideologi komunis, dikenal dengan istilah tersendiri yakni the principle of socialist legality. (Rene David dan John E. C. Brierley dalam La Ode Husen, 2009:4)

Sekalipun ada perbedaan latar belakang paham antara rechtsstaat dan the rule of law, namun lahirnya istilah "negara hukum" tidak terlepas dari pengaruh kedua paham tersebut. Dalam usaha untuk lebih mencerminkan paham Indonesia, maka dilakukan personifikasi, sehingga dalam kepustakaan Indonesia dijumpai istilah lain yang memberikan atribut "Pancasila", sebagaimana halnya juga istilah "demokrasi" diberi atribut tambahan "Pancasila", sehingga menjadi "Demokrasi Pancasila". Demikian juga istilah "negara hukum" diberi atribut Pancasila sehingga menjadi "negara hukum Pancasila". ${ }^{8}$

\footnotetext{
${ }^{7}$ Philipus M. Hadjon, op. cit., h. 80.

${ }^{8}$ La Ode Husen, loc. cit.
} 
Dalam konsepsi Islam, istilah negara hukum dikenal dengan nama "nomokrasi" adalah suatu negara hukum yang memiliki prinsip kekuasaan sebagai amanah, musyawarah, keadilan, persamaan, pengakuan dan perlindungan terhadap hak-hak asasi manusia, perdamaian, peradilan bebas, kesejahteraan dan ketaatan rakyat. (Muhammad Tahir Azhari dalam La Ode Husen) ${ }^{9}$

Berdasarkan tipe negara hukum yang telah disebutkan, berikut dipaparkan inti dari kelimanya:

Tabel 2.1 Tipe Negara Hukum

\begin{tabular}{|c|c|c|}
\hline $\begin{array}{l}\text { Tipe } \\
\text { Negara } \\
\text { Hukum }\end{array}$ & Ciri-Ciri & Unsur-Unsur Utama \\
\hline $\begin{array}{l}\text { Nomokrasi } \\
\text { Islam }\end{array}$ & $\begin{array}{l}\text { - Bersumber dari Al-Qur'an dan } \\
\text { Sunnah } \\
\text { - Nomokrasi bukan Teokrasi } \\
\text { - Persaudaraan dan Humanisme }\end{array}$ & $\begin{array}{l}\text { Musyawarah, } \\
\text { Persamaan, Peradilan } \\
\text { Bebas, Kesejahteraan }\end{array}$ \\
\hline Rechtsstaat & $\begin{array}{l}\text { - Bersumber dari rasio manusia } \\
\text { - Liberalistik/individualistik }\end{array}$ & $\begin{array}{l}\text { Pengakuan/Perlindungan } \\
\text { Hak Asasi, Trias Politika, } \\
\text { Peradilan Administrasi } \\
\text { Wetmatigberstuur }\end{array}$ \\
\hline Rule of Law & $\begin{array}{l}\text { - Bersumber dari rasio manusia } \\
\text { - Liberalistik/individualistik }\end{array}$ & $\begin{array}{l}\text { Supremacy of Law, } \\
\text { Equality before the Law, } \\
\text { Individual rights }\end{array}$ \\
\hline $\begin{array}{l}\text { Socialist } \\
\text { Legality }\end{array}$ & $\begin{array}{l}\text { - Bersumber dari rasio manusia } \\
\text { - Komunis, Atheis, Totaliter }\end{array}$ & $\begin{array}{l}\text { Hukum sebagai alat } \\
\text { sosialisme }\end{array}$ \\
\hline $\begin{array}{l}\text { Negara } \\
\text { Hukum } \\
\text { Pancasila }\end{array}$ & $\begin{array}{l}\text { - Hubungan erat antara negara } \\
\text { dengan agama, bertumpu pada } \\
\text { Ketuhanan Yang Maha Esa } \\
\text { - Asas Kekeluargaan }\end{array}$ & $\begin{array}{l}\text { Pemerintah berdasarkan } \\
\text { atas hukum, konstitusi, } \\
\text { peradilan bebas dan } \\
\text { peradilan administrasi }\end{array}$ \\
\hline
\end{tabular}

Sumber: La Ode Husen, (2009). Negara Hukum, Demokrasi dan Pemisahan Kekuasaan, Makassar: Umitoha Ukhuwah Grafika, h. 29.

Tabel di atas menunjukkan bahwa tipe negara hukum Rechtsstaat, Rule of Law dan Socialist Legality memiliki ciri-ciri yang mendasarkan pandangannya bersumber dari rasio manusia, sedangkan nomokrasi

${ }^{9}$ Ibid. 
Islam dan negara hukum Pancasila memiliki kesamaan pandangan dalam melihat hubungan antara warga negara dengan nilai-nilai Ketuhanan.

Namun demikian, Dahlan Thaib menyatakan bahwa ciri-ciri rechtsstaat juga melekat pada Indonesia sebagai sebuah Negara hukum. Ketentuan bahwa Indonesia adalah Negara hukum tidak dapat dilepaskan dari Pembukaan UUD 1945 sebagai cita negara hukum, kemudian ditentukan dalam batang tubuh dan penjelasan UUD 1945 (sebelum di amandemen). Alinea I Pembukaan UUD 1945 mengandung kata perikeadilan; dalam alinea II terdapat kata adil; dalam alinea II terdapat kata Indonesia; dalam alinea IV terdapat kata keadilan sosial dan kata kemanusiaan yang adil. Semua istilah tersebut merujuk pada pengertian Negara hukum,karena salah satu tujuan Negara hukum adalah untuk mencapai keadilan. ${ }^{10}$ Pengertian keadilan yang dimaksud dalam konsep Negara hukum Indonesia adalah bukan hanya keadilan hukum (legal justice), tetapi juga keadilan sosial (social justice).

Oemar Senoadji berpandangan bahwa Negara Hukum Indonesia memiliki ciri-ciri khas Indonesia. Karena Pancasila diangkat sebagai dasar pokok dan sumber hukum, Negara Hukum Indonesia dapat pula dinamakan Negara Hukum Pancasila. Salah satu ciri pokok dalam Negara Hukum Pancasila ialah adanya jaminan terhadap freedom of religion atau kebebasan beragama. Ciri berikutnya adalah tiada pemisahan yang rigid dan mutlak antar agama dan Negara. Karena agama dan Negara berada dalam hubungan yang harmonis.

\footnotetext{
${ }^{10}$ Dahlan Thaib, (1996), Kedaulatan Rakyat Negara Hukum dan Hak-hak Asasi Manusia, Jakarta: Media Pratama, h. 25.
} 
Padmono Wahjono memahami hukum sebagai suatu alat atau wahana untuk menyelenggarakan kehidupan Negara atau ketertiban dan menyelenggarakan kesejahteraan sosial. Pengertian ini tercermin dalam rumusan Penjelasan UUD NRI 1945 (sebelum amandemen) yang menyatakan bahwa undang-undang Dasar hanya memuat aturan-aturan pokok atau garis-garis besar sebagai instruksi kepada Pemerintah Pusat dan lain-lain penyelenggaraan Negara untuk menyelenggarakan kehidupan Negara dan kesejahteraan sosial.

Padmono Wahjono menjelaskan pula bahwa dalam UUD 1945 (sebelum amandemen) terdapat penjelasan bahwa bangsa Indonesia juga mengakui kehadiran atau eksistensi hukum tidak tertulis (selain hukum yang tertulis). Sehubungan dengan fungsi hukum, Padmo Wahjono menegaskan tiga fungsi hukum dilihat dari cara pandang berdasarkan asas kekeluargaan,yaitu: (1) menegakkan demokrasi sesuai dengan rumusan tujuh pokok sistem pemerintahan Negara dalam Penjelasan UUD 1945; (2) mewujudkan keadilan sosial sesuai dengan Pasal 33 UUD 1945; dan (3) menegakkan peri kemanusiaan yang didasarkan pada Ketuhanan Yang Maha Esa dan dilaksanakan secara adil dan beradab. ${ }^{11}$ Meskipun dalam Penjelasan UUD 1945 (sebelum diamandemen) digunakan istilah rechtsstaat, konsep rechtsstaat yang dianut oleh Negara Indonesia bukanlah konsep Negara hukum Eropa Kontinental dan bukan pula konsep the rule of law dari Anglo-Saxon, melainkan konsep Negara Hukum Pancasila dengan ciri-ciri, antara lain: (1) adanya hubungan yang

\footnotetext{
${ }^{11}$ Padmo Wahjono, (1982), Konsep Yuridis Negara Hukum Republik Indonesia, Jakarta: Rajawali, h.18.
} 
erat antara agama dan Negara; (2) bertumpu pada Ketuhanan Yang Maha Esa; (3) kebebasan beragam dalam arti positif; (4) ateisme tidak dibenarkan dan komunisme dilarang; serta (5) asas kekeluargaan dan kerukunan.

Berdasarkan pemaparan di atas dapat disimpulkan bahwa negara hukum di bagi ke dalam lima tipe yakni: Rechsstaat, the Rule of Law, Socialist Legality, Nomokrasi Islam dan Negara Hukum Pancasila. Kelima tipe negara hukum ini memiliki karakter masing-masing. Indonesia menjalankan negara hukum dalam sistem ketatanegaraan berlandaskan pada Pasal 1 ayat (3) UUD NRI 1945 yang menyatakan bahwa "negara Indonesia adalah negara hukum". Negara hukum Pancasila tidak terlepas dari pengaruh negara hukum yang telah diterapkan oleh negara lainnya seperti: Rechsstaat, the Rule of Law, Nomokrasi Islam bahkan Socialist Legality. Namun demikian, kesamaan yang hampir dimiliki oleh kelimanya adalah penghargaan terhadap hak asasi manusia.

Dalam konteks penelitian ini, Tenaga Kerja Indonesia/Pekerja Migran Indonesia yang bekerja di luar negeri tentu menghadapi sistem hukum negara tujuan yang mengacu pada salah satu dari tipe negara hukum di atas. Sehingga, proses harmonisasi Konvensi Internasional Perlindungan Hak Pekerja Migran dengan hukum nasional Indonesia menjadi solusi agar advokasi TKI/PMI di luar negeri dapat lebih diterima. Dikarenakan konvensi internasional tersebut telah mempertimbangkan nilai-nilai HAM universal dan melibatkan berbagai negara dalam penyusunannya sehingga dianggap telah mengakomodasi sistem hukum dan sistem sosial negara-negara anggota Perserikatan Bangsa-Bangsa (PBB). 


\section{Konsep Harmonisasi Hukum}

\section{a. Pengertian}

Secara ontologis kata harmonisasi berasal dari kata harmoni yang dalam bahasa Indonesia berarti pernyataan rasa, aksi, gagasan, dan minat; keselarasan; keserasian. ${ }^{12}$ Kata harmonisasi ini, di dalam bahasa Inggris disebut harmonize, dalam bahasa Prancis disebut dengan harmonie, dan dalam bahasa Yunan disebut harmonia dan dalam bahasa Yunani disebut harmonia. ${ }^{13}$ Dan istilah harmonisasi hukum sendiri muncul dalam kajian ilmu hukum pada tahun 1992 di Jerman. Dimana kajian harmonisasi hukum ini dikembangkan dengan tujuan untuk menunjukkan bahwa dalam dunia hukum, kebijakan pemerintah dan hubungan di antara keduanya terdapat keanekaragaman yang dapat mengakibatkan disharmoni.

Adapun cakupan harmonisasi hukum, L. M. Gandhi yang mengutip buku tussen eenheid en verscheidenheid: opstellen over harmonisatie instaaat en bestuurecht (1988) mengatakan bahwa harmonisasi dalam hukum adalah mencakup penyesuaian peraturan perundang-undangan, keputusan pemerintah, keputusan hakim, sistem hukum dan asas-asas hukum dengan tujuan peningkatan kesatuan hukum, kepastian hukum, keadilan (justice, grechtigheid) dan kesebandingan (equity, bilijkeid), kegunaan dan kejelasan hukum, tanpa mengaburkan dan mengorbankan pluralism hukum kalau memang dibutuhkan. Sementara menurut Badan

\footnotetext{
12 Kamus Besar Bahasa Indonesia Online, http://kbbi.web.id/harmoni, diakses 20 Desember 2016.

${ }^{13}$ Suhartono, (2011), Harmonisasi Peraturan Perundang-undangan dalam Pelaksanaan Anggaran Belanja Negara. Disertasi, Fakultas Hukum Universitas Indonesia. h. 94.
} 
Pembinaan Hukum Nasional dalam buku yang disusun oleh Moh. Hasan Wargakusumah dkk., harmonisasi hukum adalah kegiatan ilmiah untuk menuju proses pengharmonisasian tertulis yang mengacu baik pada nilainilai filosofis, sosiologis, ekonomis maupun yuridis. ${ }^{14}$

Dari uraian di atas dapat disimpulkan bahwa harmonisasi hukum diartikan sebagai upaya atau proses penyesuaian asas dan sistem hukum, agar terwujud kesederhanaan hukum, kepastian hukum dan keadilan. Harmonisasi hukum sebagai suatu proses dalam pembentukan peraturan perundang-undangan, mengatasi hal-hal yang bertentangan dan kejanggalan di antara norma-norma hukum di dalam peraturan perundang-undangan, sehingga terbentuk peraturan perundang-undangan nasional yang harmonis, dalam arti selaras, seimbang, terintegrasi dan konsisten, serta taat asas.

\section{b. Ruang Lingkup}

Penerapan peraturan perundang-undangan dalam jumlah banyak secara bersamaan dalam waktu dan ruang yang sama, sudah tentu membawa konsekuensi terjadinya disharmoni. Misalnya terjadinya tumpang tindih kewenangan dan benturan kepentingan. Penerapan berbagai macam peraturan perundang-undangan secara bersama-sama tanpa upaya-upaya harmonisasi hukum atau penyelarasan dan penyerasian sudah tentu akan menimbulkan benturan kepentingan antar lembaga. Masing-masing peraturan perundang-undangan memiliki tujuan, strategi untuk mencapai tujuan dan pedoman untuk melaksanakan

\footnotetext{
14 Ibid. h. 95.
} 
strategi, dimana ketiganya ini sering dirumuskan dalam bentuk kebijakankebijakan.

Kebijakan terdiri atas dua macam, yaitu kebijakan yang bersifat tetap atau regulatory policies yang diterapkan dalam berbagai bentuk peraturan pelaksanaan dari peraturan yang lebih tinggi tingkatannya dan kebijakan yang bersifat tidak tetap, yaitu yang mudah diubah dalam rangka mengikuti perkembangan. Dalam kaitannya ini, harmonisasi hukum dapat diawali dengan melakukan penyelarasan dan penyerasian tujuan, strategi dan pedoman dari masing-masing peraturan perundangundangan melalui upaya penafsiran hukum, konstruksi hukum, penalaran hukum dan pemberian argumentasi yang rasional dengan tetap memperhatikan sistem hukum dan asas hukum yang berlaku.

Harmonisasi hukum dalam sisi pencegahan, yaitu upaya harmonisasi yang dilakukan dalam rangka menghindarkan terjadinya disharmoni hukum. Disharmoni hukum yang telah terjadi memerlukan harmonisasi sistem hukum untuk mewujudkan tata pemerintahan yang baik dan disharmonisasi hukum yang belum terjadi harus dicegah melalui upaya-upaya penyelarasan, penyerasian dan penyesuaian berbagai kegiatan harmonisasi hukum. Demikian pula halnya, inkonsistensi dalam penjatuhan sanksi terhadap pelanggaran hukum menimbulkan terjadinya disharmoni hukum yang harus diharmonisasikan melalui kegiatan penyerasian dan penyelarasan hukum.

Di samping itu, harmonisasi hukum dilakukan untuk menanggulangi keadaan disharmoni hukum yang telah terjadi. Keadaan disharmoni 
hukum yang terlihat dalam realita, misalnya tumpang tindih kewenangan, persaingan tidak sehat, sengketa, pelanggaran, benturan kepentingan dan tindak pidana. Sehingga dalam rangka menanggulangi disharmoni antara kepentingan yang menyangkut masalah di atas harus ada upaya harmonisasi.

Potensi terjadinya disharmonisasi hukum menurut Goeniadhie tercermin oleh adanya faktor-faktor sebagai berikut: (a) jumlah peraturan perundang-undangan terlalu banyak yang diberlakukan; (b) perbedaan kepentingan dan penafsiran; (c) kesenjangan antara pemahaman teknis dan pemahaman hukum tentang tata pemerintahan yang baik; (d) kendala hukum yang dihadapi dalam penerapan peraturan perundang-undangan, yang terdiri dari mekanisme pengaturan, administrasi pengaturan, antisipasi terhadap perubahan dan penegakan hukum; dan (e) hambatan hukum yang dihadapi dalam penerapan peraturan perundang-undangan, yaitu yang berupa tumpang tindih kewenangan dan benturan kepentingan. ${ }^{15}$

\section{c. Fungsi}

Harmonisasi hukum mempunyai fungsi pencegahan dan fungsi penanggulangan terjadinya disharmoni hukum. Harmonisasi hukum untuk mencegah terjadinya disharmonisasi hukum dan hal ini dilakukan melalui penemuan hukum (penafsiran dan konstruksi hukum), penalaran hukum dan pemberian argumentasi yang rasional. Upaya ini dilakukan dengan arahan untuk menegaskan kehendak hukum, kehendak masyarakat dan

15 Kusnu Goesniadhie, (2011), Harmonisasi Sistem Hukum: Mewujudkan Tata Pemerintahan yang Baik, Malang: Nasa Media h. 11. 
kehendak moral. Harmonisasi hukum yang bersifat pencegahan dilakukan dalam rangka mengantisipasi kenyataan tentang adanya faktor-faktor potensial yang dapat menyebabkan terjadinya disharmonisasi hukum.

Harmonisasi hukum untuk menanggulangi terjadinya disharmonisasi hukum dilakukan melalui: (a) proses non-litigasi melalui alternative dispute resolution (ADR) untuk menyelesaikan persoalan sengketa perdata di luar pengadilan; (b) proses litigasi melalui courtconnected dispute resolution (CCDR) untuk mendamaikan para pihak yang bersangkutan di bidang perdata sebelum dimulai pemeriksaan di pengadilan; (c) proses litigasi sebagai pemeriksaan perkara perdata di pengadilan; (d) proses negosiasi atau musyawarah baik dengan mediator atau tidak untuk menyelesaikan disharmoni hukum publik yang tidak bersifat pidana, seperti tumpang tindih kewenangan dan benturan kepentingan antar instansi pemerintah; (e) proses pemeriksaan perkara pidana untuk mengadili pelanggaran atau tindakan kejahatan. ${ }^{16}$

Sedangkan Setiadi berpendapat bahwa ada tiga alasan atau fungsi harmonisasi hukum yaitu: (a) harmonisasi hukum dilakukan untuk menjaga keselarasan, kemantapan dan kebulatan konsepsi peraturan perundang-undangan sebagai sistem dengan tujuan peraturan tersebut dapat berfungsi secara efektif; (b) harmonisasi hukum dilakukan sebagai upaya preventif dalam rangka pencegahan diajukannya permohonan judicial review peraturan perundang-undangan kepada kekuasaan kehakiman yang berkompeten; dan (c) menjamin proses pembentukan

${ }^{16}$ Ibid. hh. 11-12. 
peraturan perundang-undangan dilakukan secara taat asas hukum demiki kepentingan dan kepastian hukum. ${ }^{17}$

Berdasarkan pendapat di atas maka dapat dipahami bahwa harmonisasi hukum berfungsi untuk pencegahan dan penanggulangan diharmoni hukum. Hal ini sejalan dengan definisi dan ruang lingkup yang telah dipaparkan pada bagian sebelumnya yakni harmonisasi hukum dapat digunakan untuk pengharmonisasian peraturan perundangundangan dan juga untuk peraturan perundang-undangan yang sudah ada sebelumnya (penanggulangan).

\section{d. Langkah-Langkah}

Sehubungan dengan langkah-langkah harmonisasi hukum, Goesniadhie membagi ke dalam lima langkah yaitu: (a) identifikasi letak disharmoni hukum dalam penerapan peraturan perundang-undangan; (b) identifikasi penyebab terjadinya disharmonisasi hukum; (c) upaya penemuan hukum dengan menggunakan metode penafsiran dan metode konstruksi hukum untuk mengubah keadaan hukum yang dihasrmoni menjadi harmoni; (d) upaya penalaran hukum agar hasil penafsiran dan konstruksi hukum tersebut masuk akal atau memenuhi unsure logika; dan (e) penyusunan argumentasi yang rasional dengan mempergunakan pemahaman tata pemerintahan yang baik untuk mendukung dan menjelaskan hasil penafsiran hukum, konstruksi huku dan penalaran hukum. ${ }^{18}$ Hal yang perlu dipahami bahwa penafsiran hukum, konstruksi

\footnotetext{
17 Wacipto Setiadi, Proses Pengharmonisasian sebagai Upaya untuk Memperbaiki Kualitas Peraturan Perundang-Undangan, Jurnal Legislatif Indonesia Vol. 4 No. 2 Juni 2007. h. 48.

${ }^{18}$ Kusnu Goesniadhie, op. cit. hh. 12-13.
} 
hukum, penalaran hukum dan argumentasi yang rasional dilakukan untuk menemukan: (a) kehendak hukum atau cita-cita hukum yaitu kepastian hukum itu sendiri; (b) kehendak masyarakat yaitu keadilan dan (c) kehendak moral yaitu kebenaran.

\section{e. Pendekatan}

Goesniadhie menyebutkan ada 4 macam pendekatan harmonisasi hukum antara lain:

1. Harmonisasi hukum mengacu pada perundang-undangan

Harmonisasi peraturan perundang-undangan dapat diartikan sebagai suatu proses penyelarasan atau penyerasian peraturan perundang-undangan yang hendak atau sedang disusun, sehingga peraturan perundang-undangan yang dihasilkan sesuai dengan prinsip-prinsip hukum dan peraturan perundangundangan yang baik. Dalam hal ini, harmonisasi hukum memegang peranan yang sangat strategis dan harus dimulai sejak tahap perencanaan agar memudahkan proses selanjutnya.

Harmonisasi hukum tidak hanya menyangkut hal-hal terkait pengaturan yang tumpang tindih atau saling bertentangan. Harmonisasi hukum juga memegan peranan penting dalam melahirkan suatu produk peraturan perundang-undangan yang dapat dijalankan dan diterima oleh masyarakat dengan baik.

Harmonisasi peraturan perundang-undangan tidak hanya terbatas pada macam atau jenis peraturan perundang- 
undangan beserta tata urutannya. Secara ideal dilakukan terintegrasi yang meliputi segala aspek dari paham peraturan perundang-undangan yaitu: (a) pengertian umum peraturan perundang-undangan; (b) makna urutan peraturan perundangundangan; (c) fungsi tata urutan peraturan perundangundangan; (d) penamaan masing-masing peraturan perundangundangan; (e) pengertian masing-masing peraturan perundangundangan; (f) hubungan norma peraturan perundang-undangan dengan norma hukum yang lain.

Harmonisasi peraturan perundang-undangan merupakan upaya penyelarasan dan penyerasian tujuan, strategi dan pedoman dilakukan dengan mengacu pada hukum dasar yaitu Undang-Undang Dasar Negara Republik Indonesia (UUD NRI) 1945 dan peraturan perundang-undangan yang mendasari tata pemerintahan yang baik. Di samping itu, harus selaras dan serasi dengan perubahan hukum dasar dan hukum yang mendasarinya menuju tata pemerintahan yang baik.

2. Harmonisasi hukum mengacu ruang lingkup Harmonisasi hukum dalam pengertian upaya harmonisasi tujuan, strategi untuk mencapai tujuan dan pedoman untuk melaksanakan strategi agar tujuan dari masing-masing peraturan perundang-undangan tercapai.

3. Harmonisasi hukum mengacu pada keterpaduan kelembagaan 
Aspek hukum atau kelembagaan dalam tata pemerintahan yang baik diwujudkan dalam bentuk interaksi hukum dan kelembagaan. Oleh karena interaksi hukum dan kelembagaan terjadi di setiap komponen kegiatan dan juga antara komponen kegiatan, maka keterpaduan tersebut hendaknya diupayakan untuk terwujud di setiap tingkatan interaksi hukum dan kelembagaan.

Upaya untuk memadukan peraturan perundang-undangan, menyelaraskan dan menyerasikan dapat dilakukan melalui penafsiran hukum, penalaran hukum dan argumentasi rasional dengan memperhatikan kepentingan masing-masing lembaga dengan arahan utama untuk mengembangkan suatu produk hukum yang baik. Apabila keterpaduan hukum dapat terwujud, maka keterpaduan dalam aplikasinya juga harus selalu selaras dengan nilai-nilai muatan agama. Sehingga keterpaduan kelembagaan senantiasa akan menjadi jaminan bagi diselenggarakannya harmonisasi hukum dalam mewujudkan produk hukum yang lebih baik.

4. Harmonisasi hukum mengacu pada kodifikasi dan unifikasi

Upaya kodifikasi dan unifikasi hukum merupakan upaya untuk membatasi dan mengunci hasil harmonisasi hukum agar tidak berubah lagi. Jika terjadi perubahan, maka perubahan tersebut harus mengacu pada unifikasi hukum yang telah dikodifikasikan. Upaya kodifikasi adalah upaya untuk 
menghimpun peraturan perundang-undangan ke dalam satu buku. Unifikasi hukum ditandai dengan karakteristik sebagai berikut: (1) adanya satu kitab undang-undang; (2) adanya satu persepsi atau satu pemahaman tentang hukum yang berlaku; (3) adanya satu sikap dan perilaku terhadap hukum yang berlaku; (4) adanya prinsip-prinsip non-diskriminatif; dan (5) adanya konsistensi dalam penerapan dan penegakan hukum.

Terwujudnya kodifikasi dan unifikasi hukum akan menjamin terwujudnya kepastian hukum dan keadilan. Di samping itu, kodifikasi dan unifikasi hukum akan menjadi landasan bagi pengembangan dinamika harmonisasi hukum.

Berdasarkan penjelasan di atas tentang harmonisasi hukum, mulai dari pengertian, ruang lingkup, fungsi, langkah-langkah dan pendekatan. Maka dalam penelitian ini, harmonisasi hukum dimaknai sebagai upaya penyelarasan konvensi internasional perlindungan hak pekerja migran yang telah diratifikasi dalam UU No. 6 Tahun 2012 tentang pengesahan International Convention on the Protection of The Rights Of All Migrant Workers and Members of Their Families (Konvensi Internasional mengenai Perlindungan Hak-Hak Seluruh Pekerja Migran dan Anggota Keluarganya) dengan Undang-Undang Nomor 39 Tahun 2004 tentang Penempatan dan Perlindungan Tenaga Kerja Indonesia di Luar Negeri (PPTKILN). Konvensi internasional perlindungan hak pekerja migran ini merupakan salah satu instrumen internasional yang mengatur urusan pekerja migran secara komprehensif. Sehingga nilai-nilai yang terkandung 
dalam konvensi dapat diharmonisasi ke dalam hukum nasional Indonesia di bidang ketenagakerjaan, khususnya bidang migrasi kerja.

\section{Konsep Perjanjian Internasional}

Konvensi merupakan salah satu penamaan dari perjanjian internasional. Sebagaimana diungkapkan oleh Brierly (1972: 137) dalam Tsani (1990) yang menyatakan definisi perjanjian internasional sebagai berikut.

Contractual engagements between states are called by various names- treaties, conventions, pacts, acts, declarations, protocols. ${ }^{19}$ (Perjanjian kontraktual antar negara disebut dengan beberapa nama perjanjian internasional (treaties), konvensi (convention), pakta (pacts), act, deklarasi (declaration), dan protokol (protocol).

Oppenheim (1952: 791, 792) memberi batasan perjanjian internasional sebagai berikut:

International treaties are conventions, or contracts, between two or more states concerning various matters of interest. ${ }^{20}$ (Perjanjian internasional adalah konvensi atau kontrak antar dua negara atau lebih mengenai berbagai macam kepentingan)

Selanjutnya definisi perjanjian internasional dapat pula ditemukan dalam Konvensi Wina 1969 dan Konvensi Wina 1986. Menurut ketentuan pasal 2 ayat 1 huruf a Konvensi Wina 1969, perjanjian internasional adalah:

Treaty means an international agreement concluded between states in writer form and governed by international law, whether embodied in a single instrument or in two or more related instrument and whatever its particular designation. ${ }^{21}$ (Perjanjian internasional berarti suatu persetujuan internasional yang ditandatangani antar negara dalam bentuk tertulis dan

\footnotetext{
${ }^{19}$ Mohd. Burhan Tsani, (1990), Hukum dan Hubungan Internasional, Yogyakarta: PAUStudi Sosial UGM. h. 65.

${ }_{20} \mathrm{lbid}$.

${ }^{21}$ lbid.
} 
diatur oleh hukum internasional, apakah dibuat dalam wujud satu instrumen tunggal atau dalam dua instrumen yang saling berhubungan atau lebih dan apapun yang menjadi penandaan khususnya).

Agusman (2010) menyatakan definisi dari Konvensi Wina 1969 dan 1986 telah diadopsi oleh Undang-Undang No. 24 Tahun 2000 tentang Perjanjian Internasional dengan sedikit modifikasi yaitu: "setiap perjanjian di bidang hukum publik, yang diatur oleh hukum internasional dan dibuat oleh Pemerintah dengan Negara, organisasi internasional atau subjek hukum internasional lain". Dari pengertian hukum ini, maka terdapat beberapa kriteria dasar atau parameter yang harus dipenuhi oleh suatu dokumen perjanjian untuk ditetapkan sebagai suatu perjanjian internasional menurut Konvensi Wina 1969 dan UU No. 24 Tahun 2000 tentang Perjanjian Internasional, yaitu:

1. Perjanjian tersebut harus berkarakter internasional (an international agreement), sehingga tidak mencakup perjanjianperjanjian yang berskala nasional seperti perjanjian antarnegara bagian atau antara Pemerintah Daerah dari suatu negara nasional;

2. Perjanjian tersebut harus dibuat oleh negara dan/atau organisasi internasional (by subject of international law), sehingga tidak mencakup perjanjian yang sekalipun bersifat internasional namun dibuat oleh non-subjek hukum internasional, seperti perjanjian antara negara dengan perusahaan multinasional; 
3. Perjanjian tersebut tinduk pada rezim hukum internasional (governed by international law) yang oleh UU No. 24 Tahun 2000 disebut dengan "diatur dalam hukum internasional serta menimbulkan hak dan kewajiban di bidang hukum publik". Perjanjian-perjanjian yang tunduk pada hukum perdata nasional tidak tercakup dalam kriteria ini. ${ }^{22}$

Agusman (2010) menyatakan bahwa praktik di Indonesia tentang pembuatan perjanjian internasional baik sebelum dan sesudah lahirnya UU No. 24 Tahun 2000 tidak luput dari kerancuan pemahaman tentang perjanjian internasional. Pasal 11 UUD 1945 hanya menyebut "perjanjian dengan negara lain" dan tidak mendefinisikan tentang apa yang dimaksudkan dengan perjanjian tersebut. Secara harfiah maka terdapat kecenderungan untuk mengartikan "perjanjian" sebagai semua perjanjian terlepas dari apakah perjanjian tersebut adalah perjanjian perdata atau publik. ${ }^{23}$

Agusman (2010) melanjutkan bahwa pengertian "perjanjian" pada Pasal 11 UUD 1945 tidak dimaksudkan untuk mencakup perjanjian perdata antarnegara. Hal ini tersirat dari ditempatkannya pasal ini diantara Pasal 10 sampai dengan Pasal 15, yang oleh penjelasan UUD 1945 disebut bahwa "kekuasaan-keukasaan Presiden dalam pasal-pasal ini ialah konsekuensi dari kedudukan Presiden sebagai kepala negara". Dalam Konstitusi RI dan UUDS 1950, materi tentang perjanjian ini juga ditempatkan dalam Bab tentang Hubungan Luar Negeri. Mengingat bahwa

${ }^{22}$ Damos Dumoli Agusman, (2010), Hukum Perjanjian Internasional: Kajian Teori dan Praktik Indonesia, Bandung: Refika Aditama. h. 20.

${ }^{23}$ Ibid. h. 23. 
pembuatan perjanjian dimaksud adalah dalam rangka kekuasaan Presiden sebagai Kepala Negara dan termasuk dalam kategori "Perhubungan Luar Negeri", maka perjanjian dimaksud adalah tidak lain dari perjanjian publik karena secara tradisional interaksi oleh kepala negara dalam hubungan luar negeri tidak pernah menghasilkan perjanjian perdata, melainkan perjanjian yang tunduk pada hukum internasional. ${ }^{24}$

Berdasarkan penjelasan di atas maka dapat dipahami bahwa Konvensi internasional perlindungan hak pekerja migran telah memenuhi kriteria secara internasional (Konvensi Wina 1969) dan nasional (UU No. 24 Tahun 2000) sebagai perjanjian internasional (konvensi). Hal ini menegaskan bahwa konvensi internasional ini patut menjadi rujukan bagi Indonesia untuk pengembangan sistem perlindungan pekerja migran Indonesia dalam UU No. 39 Tahun 2004.

\section{Perjanjian Internasional sebagai Sumber Hukum Tata Negara}

Dalam Black's Law Dictionary, sumber hukum atau dalam bahasa Inggris disebut "sources of law", diartikan sebagai: "the origins from which particular positive laws derive their authority and coercive force; such are constitutions, treaties, statutes, usages and customs" ${ }^{\prime 25}$. Dengan terjemahan bebas, asal-usul yang berasal dari otoritas dan kekuatan pemaksaan mereka; seperti: konstitusi, perjanjian, undang-undang, penggunaan dan kebiasaan.

Menurut Usep Ranawijaya dalam Sirajuddin dan Winardi, sumber hukum memiliki dua arti. Arti pertama adalah sumber sebagai penyebab

\footnotetext{
${ }^{24}$ Ibid.

${ }^{25}$ Henry Campbell Black et., al., (1991), Black Law Dictionary with Pronounciations, St. Paul, Minn: West Publishing Co., h. 970.
} 
adanya hukum. Dan penyebab adanya hukum tidak lain adalah keyakinan hukum dari orang-orang yang melakukan peranan menentukan tentang apa yang harus menjadi hukum di Negara. Sumber hukum dalam arti yang demikian ini di dalam kamus Belanda dikenal dengan nama "webron". Menurut Usep, sumber hukum dalam arti ini kurang penting bagi ilmu hukum tata negara Indonesia untuk diselidiki. Arti kedua adalah sumber hukum dalam pengertian bentuk perumusan kaidah-kaidah hukum tata Negara yang terdapat di dalam masyarakat dari mana kita dapat mengetahui apa yang menjadi hukum itu. Sumber hukum dalam arti formal ini dikenal dalam bahasa Belanda dengan nama "kenbron". ${ }^{26}$

Bagir Manan dalam Sirajuddin dan Winardi mengemukakan bahwa sumber hukum tata negara mencakup sumber hukum dalam arti materiil dan sumber hukum dalam arti formal. Sumber hukum materiil tata Negara adalah sumber yang menentukan isi kaidah hukum tata Negara. Termasuk ke dalam sumber hukum dalam arti materiil ini misalnya: (1) dasar dan pandangan hidup bernegara; dan (2) kekuatan-kekuatan politik yang berpengaruh pada saat merumuskan kaidah-kaidah hukum tata Negara. Selanjutnya, sumber hukum tata Negara dalam arti formal terdiri atas: (1) hukum perundang-undangan ketatanegaraan; (2) hukum adat ketatanegaraan; (3) hukum kebiasaan ketatanegaraan; (4) yurisprudensi ketatanegaraan; (5) hukum perjanjian internasional ketatanegaraan; dan (6) doktrin ketatanegaraan. ${ }^{27}$

\footnotetext{
${ }^{26}$ Sirajuddin dan Winardi, (2015), Dasar-Dasar Hukum Tata Negara Indonesia, Malang: Setara Press. hh. 10-11.

${ }^{27}$ Ibid. hh. 11-12.
} 
Sirajuddin dan Winardi menyatakan bahwa sumber hukum formal adalah sumber hukum yang berasal dari aturan-aturan hukum yang sudah mempunyai bentuk berlakunya hukum. Dengan demikian sumber hukum formal ini merupakan pemberian bentuk pernyataan bahwa sumber hukum materiil dinyatakan berlaku dengan hukum formal. Sumber-sumber hukum formal dari hukum tata negara Republik Indonesia mengadopsi dari Bagir Manan terdiri atas: peraturan perundang-undangan, konvensi, perjanjian internasional, yurisprudensi dan doktrin. ${ }^{28}$

Salah satu sumber hukum tata negara Indonesia yakni perjanjian internasional. Menurut Sirajuddin dan Winardi, perjanjian internasional memainkan peranan yang sangat penting dalam mengatur kehidupan dan pergaulan antar Negara dalam masyarakat internasional dewasa ini. Melalui perjanjian internasional, tiap negara menggariskan dasar kerjasama mereka, mengatur berbagai kegiatan, menyelesaikan berbagai masalah demi keberlangsungan hidup masyarakat itu sendiri. Dalam dunia yang saling ditandai saling ketergantungan dewasa ini, tidak ada satu negara yang tidak mempunyai perjanjian dengan dengara lain dan tidak ada satu negara yang tidak diatur oleh perjanjian dalam kehidupan internasionalnya. $^{29}$

Dalam Pasal 2 Konvensi Wina 1969, perjanjian internasional (treaty) didefinisikan sebagai: "suatu perjanjian yang dibuat antara negara dalam bentuk tertulis, dan diatur oleh hukum internasional, apakah dalam instrumen tunggal atau dua atau lebih instrumen yang berkaitan dan

\footnotetext{
${ }^{28}$ Ibid. h. 12.

${ }^{29}$ Ibid. h. 19.
} 
apapun nama yang diberikan padanya. Sementara Pasal 1 ayat (3) Undang-Udang Republik Indonesia Nomor 37 Tahun 1999 tentang Hubungan Luar Negeri menyatakan: "Perjanjian internasional adalah perjanjian dalam bentuk dan sebutan apapun, yang diatur oleh hukum internasional dan dibuat secara tertulis oleh pemerintah Republik Indonesia dengan satu atau lebih Negara, organisasi internasional atau subjek hukum internasional lainnya, serta menimbulkan hak dan kewajiban pada pemerintah Republik Indonesia yang bersifat hukum publik.

Dari pemaparan tersebut di atas, Ni'matul Huda dalam Sirajuddin dan Winardi berpendapat bahwa perjanjian internasional yang kemudian menjadi sumber hukum tata negara adalah perjanjian internasional yang diadakan oleh Indonesia dengan Negara-negara lain, dimana Indonesia sebagai Negara berdaulat telah mengikatkan diri untuk menerima hak-hak dan kewajiban yang timbul dari perjanjian yang diadakan itu. Perjanjian internasional merupakan sumber hukum yang penting. Untuk itu, tidak cukup perjanjian atau traktat ditandatangani oleh Indonesia, namun harus pula diratifikasi (mendapatkan pengesahan) sebelum perjanjian tersebut mengikat. Di samping traktat (treaty), ada perjanjian internasional biasa yang diadakan oleh pemerintah atau badan eksekutif (executive agreement) dengan pemerintah lain yang tidak memerlukan pengesahan (ratifikasi). ${ }^{30}$

30 Ibid. h. 20. 


\section{Teori Hubungan Perjanjian Internasional dengan Hukum Nasional}

Agusman (2010) berpendapat bahwa hukum, doktrin dan praktik Indonesia tentang status perjanjian internasional dalam hukum nasional RI belum berkembang dan sering menimbulkan persoalan praktis dalam tataran implementasi perjanjian internasional di dalam kerangka sistem hukum nasional. Ketidakjelasan ini merupakan bagian dari ketiadaan hukum maupun doktrin pada sistem hukum Indonesia tentang hubungan hukum internasional dan hukum nasional. Berbagai kebingungan mencuat dalam dunia praktisi untuk menjawab pertanyaan tentang status perjanjian internasional dalam sistem hukum Indonesia. ${ }^{31}$

Agusman (2010) melanjutkan dalam tataran teori hukum tata negara, perjanjian internasional (traktat) sudah dikenal sebagai sumber hukum dan kedudukannya adalah berdiri sendiri dan terpisah dari Undang-Undang. Namun menurut Bagir Manan dituangkannya perjanjian internasional ke dalam bentuk undang-undang pengesahan, terlepas dari arti kedudukan Undang-Undang ini, merupakan suatu "kontradiksi keilmuan". 32

Menurut Agusman (2010) sejak mulai berlakunya UUD 1945, tidak terdapat praktik bahkan wacana sekalipun untuk mengkonstruksikan perjanjian internasional ke dalam sistem perundang-undangan. Dalam hukum dan praktik Indonesia sampai akhir Orde Baru, status perjanjian internasional tidak dipersoalkan dalam perspektif perundang-undangan karena memang belum ada ketertarikan hukum tata negara Indonesia

\footnotetext{
${ }^{31}$ Damos Dumoli Agusman, op. cit., h. 95.

32 lbid.
} 
tentang kedudukan dan status perjanjian internasional dalam sistem hukum nasional Indonesia.

Agusman (2010) menyatakan bahwa UU No. 24 Tahun 2000 tentang Perjanjian Internasional tidak secara tegas menjelaskan kedudukan perjanjian internasional dalam sistem perundang-undangan, namun hanya menyatakan bahwa perjanjian internasional disahkan dengan Undang-Undang/Peraturan Presiden tanpa lebih lanjut menjelaskan apa arti dan konsekuensinya bagi perundang-undangan Indonesia. Apakah dengan pengesahan melalui Undang-Undang maka perjanjian internasional menjadi setara dengan Undang-Undang merupakan pertanyaan yang masih belum terjawab sampai saat ini.

Jika dikaji lebih lanjut dalam UU No. 10 Tahun 2004 dan telah mengalami perubahan dalam UU No. 12 Tahun 2011 tentang Pembentukan Peraturan Perundang-Undangan, perjanjian internasional masih belum dimasukkan dalam susunan jenis peraturan perundangundangan. Hal ini dapat dilihat pada Pasal 7 tentang hierarki perundangundangan sebagai berikut:

Tabel 2.2 Perbandingan Hierarki Perundang-Undangan

\begin{tabular}{|c|c|}
\hline UU No. 10 Tahun 2004 & UU No. 12 Tahun 2011 \\
\hline $\begin{array}{l}\text { a. Undang-Undang Dasar Negara } \\
\text { Republik Indonesia Tahun 1945; }\end{array}$ & $\begin{array}{l}\text { a. Undang-Undang Dasar Negara } \\
\text { Republik Indonesia Tahun 1945; }\end{array}$ \\
\hline 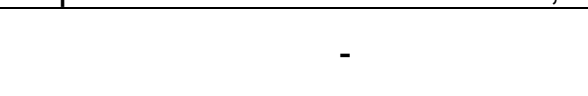 & $\begin{array}{l}\text { b. Ketetapan Majelis Permusyawaratan } \\
\text { Rakyat; }\end{array}$ \\
\hline $\begin{array}{l}\text { b. Undang-Undang/Peraturan } \\
\text { Pemerintah Pengganti Undang- } \\
\text { Undang; }\end{array}$ & $\begin{array}{l}\text { c. Undang-Undang/Peraturan } \\
\text { Pemerintah Pengganti Undang- } \\
\text { Undang; }\end{array}$ \\
\hline c. Peraturan Pemerintah; & d. Peraturan Pemerintah; \\
\hline d. Peraturan Presiden; & e. Peraturan Presiden; \\
\hline \multirow[t]{2}{*}{ e. Peraturan Daerah. } & f. Peraturan Daerah Provinsi; dan \\
\hline & g. Peraturan Daerah Kabupaten/Kota. \\
\hline
\end{tabular}

Berdasarkan Tabel 2.2 terlihat bahwa hierarki perundang-undangan dalam UU No. 10 Tahun 2004 yang kemudian di revisi pada UU No. 12 
Tahun 2011 hanya memperlihatkan dikembalikannya Ketetapan Majelis Permusyawaratan Rakyat (Tap MPR) ke dalam hierarki dan pembagian lebih rinci peraturan daerah yakni peraturan daerah Provinsi dan peraturan daerah Kabupaten/Kota. Kenyataan ini semakin membuktikan bahwa masih tidak jelasnya doktrin tentang status hukum dari perjanjian internasional dalam hukum Indonesia.

Agusman (2010) berpendapat bahwa dalam tataran praktis di kalangan pemerintah dan opini publik berkembang berbagai alur pikiran yang dapat dipetakan sebagai berikut: (1) alur pikiran yang menempatkan perjanjian internasional yang telah disahkan (diratifikasi) sebagai bagian dari hukum nasional; dan (2) alur pikiran yang mengharuskan adanya legislasi nasional tersendiri untuk mengimplementasikan suatu perjanjian internasional yang telah disahkan. ${ }^{33}$

Agusman (2010) melanjutkan secara teoretis persoalan ini berakar pada ketidakjelasan tentang aliran/doktrin yang dianut oleh hukum Indonesia tentang hubungan hukum internasional dan hukum nasional. Pada negara-negara maju, aliran ini telah dicerminkan dalam constitutional provisions atau Undang-Undang nasional yang secara tegas memuat kaidah tentang status hukum internasional dalam hukum nasionalnya. Sistem hukum Indonesia sayangnya masih belum memberi perhatian pada permasalahan ini, sehingga jangankan suatu constitutional legal provisions, wacana publik ke arah pembentukan politik hukum tentang persoalan ini juga belum dimulai. ${ }^{34}$

\footnotetext{
${ }^{33}$ Ibid. h. 96.

${ }^{34}$ lbid.
} 
Agusman (2010) menyatakan dalam teori terdapat beberapa pilihan politik hukum yaitu:

(a) aliran dualisme yang menempatkan hukum internasional sebagai sistem hukum yang terpisah dari hukum nasional. Dalam hal ini tidak terdapat hubungan hierarki antara kedua sistem hukum ini. Konsekuensi dari aliran ini adalah diperlukannya lembaga hukum "transformasi" untuk mengkonversikan hukum internasional ke dalam hukum nasional berdasarkan peraturan perundang-undangan yang berlaku untuk prosedur konversi ini. Pengikatan diri suatu negara ke suatu perjanjian (misalnya melalui ratifikasi) harus dilanjutkan proses transformasi melalui pembuatan legislasi nasional. Dengan dikonversikannya kaidah hukum internasional ini ke dalam hukum nasional, maka kaidah tersebut akan berubah karakter menjadi produk hukum nasional dan berlaku sebagai hukum nasional serta tunduk dan masuk pada tata urutan perundangan-undangan nasional. Karena sistem yang terpisah maka tidak memungkinkan adanya konflik di antara kedua hukum ini;

(b) Aliran monisme yang menempatkan hukum internasional dan hukum nasional sebagai bagian dari satu kesatuan sistem hukum. Hukum internasional berlaku dalam ruang lingkup hukum nasional tanpa harus melalui proses transformasi. Pengikatan diri suatu negara kepada suatu perjanjian (misalnya 
dengan ratifikasi) merupakan inkorporasi perjanjian tersebut ke dalam hukum nasional dan tidak dibutuhkan legislasi nasional yang sama untuk memberlakukannya dalam hukum nasional. Kalaupun ada legislasi nasional yang mengatur masalah yang sama maka legislasi yang dimaksud hanya merupakan implementasi dari kaidah hukum internasional dimaksud. Dalam hal ini, hukum internasional yang berlaku dalam sistem hukum nasional akan tetap pada karakternya sebagai hukum internasional. Mengingat merupakan kesatuan sistem maka terdapat kemungkinan adanya konflik antara hukum nasional dan hukum internasional. Untuk itu aliran ini kemudian terbagi menjadi dua yaitu yang mendahulukan hukum nasional (primat hukum nasional) dan yang mendahulukan hukum internasional (primat hukum internasional). ${ }^{35}$

Tabel 2.3. Perbandingan Monisme dan Dualisme

\begin{tabular}{|l|l|}
\hline \multicolumn{1}{|c|}{ Monisme } & \multicolumn{1}{c|}{ Dualisme } \\
\hline $\begin{array}{l}\text { - Hukum internasional dan hukum } \\
\text { nasional merupakan suatu kesatuan } \\
\text { sistem. }\end{array}$ & $\begin{array}{l}\text { - Hukum internasional dan hukum } \\
\text { nasional berlaku pada wilayah yang } \\
\text { berbeda }\end{array}$ \\
\hline $\begin{array}{l}\text { - Aparat hukum menerapkan norma } \\
\text { hukum internasional dalam } \\
\text { statusnya sebagai norma hukum } \\
\text { internasional. }\end{array}$ & $\begin{array}{l}\text { - Aparat hukum menerapkan hukum } \\
\text { internasional dalam statusnya } \\
\text { sebagai norma hukum nasional. }\end{array}$ \\
\hline $\begin{array}{l}\text { - Hukum internasional di inkorporasi } \\
\text { dengan hukum nasional. }\end{array}$ & $\begin{array}{l}\text {-Hukum internasional ditransformasi } \\
\text { ke dalam hukum nasional. }\end{array}$ \\
\hline $\begin{array}{l}\text { - Terbuka munculnya konflik antara } \\
\text { hukum internasional dengan hukum } \\
\text { nasional. Melahirkan primat hukum } \\
\text { internasional atau primat hukum } \\
\text { nasional. }\end{array}$ & $\begin{array}{l}\text { - Tidak mungkin terjadi konflik } \\
\text { karena wilayahnya berbeda. }\end{array}$ \\
\hline
\end{tabular}

Sumber: Agusman (2010:97-98)

${ }^{35}$ lbid. h. 97. 
Di negara-negara hukum modern seperti Amerika Serikat, Inggris dan negara-negara Eropa Barat, pengembangan doktrin tentang hubungan hukum ini telah digulirkan sejak awal abad ke-20-an melalui proses wacana publik yang cukup panjang termasuk pada proses legislasi maupun yurisprudensi yang akhirnya terkristalisasi dalam suatu pilihan politik hukum baik monism, dualisme maupun kombinasi keduanya. Pada negara-negara tersebut, persoalan status hukum internasional baik hukum kebiasaan internasional maupun perjanjian internasional dalam hukum nasional mereka telah tuntas dan pada umumnya dapat dipetakan sebagai penganut aliran monisme (Belanda, Italia, Perancis), dualisme (Amerika Serikat, Inggris, Australia) atau kombinasi keduanya (Jerman, monisme untuk hukum kebiasaan internasional dan dualisme untuk perjanjian internasional). ${ }^{36}$

Penjelasan di atas mengenai teori hubungan perjanjian internasional dengan hukum nasional dalam penelitian ini akan digunakan untuk menjelaskan bagaimana harmonisasi konvensi internasional perlindungan hak pekerja migran dengan UU No. 39 Tahun 2004 tentang Penempatan dan Perlindungan Tenaga Kerja Indonesia di Luar Negeri (PPTKILN) yang saat ini sudah dalam bentuk Rancangan Undang-Undang Perlindungan Pekerja Migran Indonesia.

\section{Konsep Pekerja Migran Indonesia}

Pekerja Migran Indonesia/Tenaga Kerja Indonesia (TKI) adalah setiap warga negara Indonesia yang memenuhi syarat untuk bekerja di

${ }^{36}$ lbid. h. 98. 
luar negeri dalam hubungan kerja untuk jangka waktu tertentu dengan menerima upah. Sementara itu, Calon Tenaga Kerja Indonesia (CTKI) didefinisikan setiap warga negara Indonesia yang memenuhi syarat sebagai pencari kerja yang akan bekerja di luar negeri dan terdaftar di instansi pemerintah kabupaten/kota yang bertanggung jawab di bidang ketenagakerjaan. (Pasal 1 UU No. 39 Tahun 2004)

Pasal 35 UU No. 39/2004 menjelaskan syarat-syarat TKI untuk bekerja di luar negeri, antara lain: (1) berusia sekurang-kurangnya 18 tahun, kecuali bagi calon TKI yang dipekerjakan pada pengguna perseorangan/rumah tangga sekurang-kurangnya berusia 21 tahun; (2) sehat jasmani dan rohani; (3) tidak dalam keadaan hamil bagi calon tenaga kerja perempuan; (4) berpendidikan sekurang-kurangnya lulus SLTP atau yang sederajat; (5) terdaftar di Dinas Ketenagakerjaan di daerah tempat tinggalnya; (6) memiliki dokumen lengkap.

Poin 6 Pasal 35 UU No. 39/2004 tentang syarat bekerja di luar negeri dijelaskan lebih lanjut pada pasal 51 UU No. 39/2004 antara lain: (1) KTP, ijazah pendidikan terakhir, akte kelahiran atau surat keterangan kenal lahir; (2) surat keterangan status perkawinan, bagi yang telah menikah melampirkan copy buku nikah; (3) surat keterangan izin suami/istri, izin orang tua atau izin wali; (4) sertifikasi kompetensi kerja; (5) surat keterangan sehat berdasarkan hasil pemeriksaan kesehatan dan psikologi; (6) paspor yang diterbitkan oleh Kantor Imigrasi setempat; (7) visa kerja; (8) perjanjian penempatan TKI; (9) perjanjian kerja; dan (10) KTKLN (Kartu Tenaga Kerja Luar Negeri). 
Penjelasan di atas secara jelas mendefinisikan bahwa pekerja migran Indonesia atau tenaga kerja Indonesia adalah warga negara Indonesia dengan kriteria: 1) memenuhi syarat untuk bekerja di luar negeri, 2) hubungan kerja untuk jangka waktu tertentu dan 3) menerima upah.

\section{Pekerja Migran Indonesia dalam UU Nomor 39 Tahun 2004}

Sebelum lahirnya Undan-Undang Nomor 39 Tahun 2004, pengaturan terhadap Pekerja Migran Indonesia/Tenaga Kerja Indonesia di luar negeri diatur dalam Ordonansi tentang Pengerahan Orang Indonesia untuk Melakukan Pekerjaan di Luar Negeri (Staatsblad Tahun 1887 No. 8) yang berasal dari aturan Belanda. Pasca kemerdekaan, aturan tersebut hanya ditambahkan dengan berbagai Peraturan Menteri sebagai petunjuk pelaksanaan. Sehingga jika dibandingkan dengan UU, maka aturan tersebut tentunya memiliki kekuatan hukum yang lemah. ${ }^{37}$

Perhatian pemerintah di bidang ketenagakerjaan baru dilakukan sejak reformasi hukum di bidang ketenagakerjaan dengan disahkannya Undang-Undang No. 13 Tahun 2003 tentang Ketenagakerjaan. Dengan hadirnya UU tersebut, maka Ordonansi tentang Pengerahan Orang Indonesia untuk Melakukan Pekerjaan di Luar Negeri dinyatakan tidak berlaku lagi dan diamanatkan agar penempatan tenaga kerja ke luar negeri diatur dengan undang-undang tersendiri. Menindaklanjuti amanat UU 13/2003 tersebut, maka pada tahun 2004, disahkan sebuah UU yang mengatur tentang mekanisme penempatan dan perlindungan TKI di luar

37 Achmad Zulfikar. (2013). Alasan Pemerintah Indonesia Meratifikasi Konvensi Internasional Perlindungan Hak Pekerja Migran Tahun 2012. Skripsi. Universitas Muhammadiyah Yogyakarta. hh. 41-42. 
negeri yakni UU No. 39 Tahun 2004 tentang Penempatan dan Perlindungan TKI di Luar Negeri. ${ }^{38}$

UU No. 39 Tahun 2004 dalam bagian pertimbangan menekankan aspek hak asasi manusia (HAM) sebagai inti dari pelaksanaan penempatan dan perlindungan TKI di luar negeri, selengkapnya sebagai berikut: (a) bahwa bekerja merupakan hak asasi manusia yang wajib dijunjung tinggi, dihormati, dan dijamin penegakannya; (b) bahwa setiap tenaga kerja mempunyai hak dan kesempatan yang sama tanpa diskriminasi untuk memperoleh pekerjaan dan penghasilan yang layak, baik di dalam maupun di luar negeri sesuai dengan keahlian, keterampilan, bakat, minat, dan kemampuan; (c) bahwa tenaga kerja Indonesia di luar negeri sering dijadikan obyek perdagangan manusia, termasuk perbudakan dan kerja paksa, korban kekerasan, kesewenang wenangan, kejahatan atas harkat dan martabat manusia, serta perlakuan lain yang melanggar hak asasi manusia; (d) bahwa negara wajib menjamin dan melindungi hak asasi warga negaranya yang bekerja baik di dalam maupun di luar negeri berdasarkan prinsip persamaan hak, demokrasi, keadilan sosial, kesetaraan dan keadilan gender, anti diskriminasi, dan anti perdagangan manusia.

UU No. 39/2004 ini juga menyebutkan: (e) bahwa penempatan tenaga kerja Indonesia di luar negeri merupakan suatu upaya untuk mewujudkan hak dan kesempatan yang sama bagi tenaga kerja untuk memperoleh pekerjaan dan penghasilan yang layak, yang

${ }^{38} \mathrm{lbid}$. 
pelaksanaannya dilakukan dengan tetap memperhatikan harkat, martabat, hak asasi manusia dan perlindungan hukum serta pemerataan kesempatan kerja dan penyediaan tenaga kerja yang sesuai dengan kebutuhan nasional; dan (f) bahwa penempatan tenaga kerja Indonesia di luar negeri perlu dilakukan secara terpadu antara instansi Pemerintah baik Pusat maupun Daerah dan peran serta masyarakat dalam suatu sistem hukum guna melindungi tenaga kerja Indonesia yang ditempatkan di luar negeri.

Hak dan kewajiban TKI secara eksplisit disebutkan dalam Bab III Pasal 8-9 UU No. 39/2004 sebagai berikut. Setiap calon TKI mempunyai hak dan kesempatan yang sama untuk: (a) bekerja di luar negeri; (b) memperoleh informasi yang benar mengenai pasar kerja luar negeri dan prosedur penempatan TKI di luar negeri; (c) memperoleh pelayanan dan perlakuan yang sama dalam penempatan di luar negeri; (d) memperoleh kebebasan menganut agama dan keyakinannya serta kesempatan untuk menjalankan ibadah sesuai dengan agama dan keyakinan yang dianutnya; (e) memperoleh upah sesuai dengan standar upah yang berlaku di negara tujuan; (f) mempeoleh hak, kesempatan dan perlakuan yang sama yang diperoleh tenaga kerja asing lainnya sesuai dengan peraturan perundang-undangan di negara tujuan; $(\mathrm{g})$ memperoleh jaminan perlindungan hukum sesuai dengan peraturan perundang-undangan atas tindakan yang dapat merendahkan harkat dan martabatnya serta pelanggaran atas hak-hak yang ditetapkan sesuai dengan peraturan perundang-undangan selama penempatan di luar negeri. 
Hak TKI selanjutnya: (h) memperoleh jaminan perlindungan keselamatan dan keamanan kepulangan TKI ke tempat asal; dan (i) memperoleh naskah perjanjian kerja yang asli. Sedangkan kewajiban setiap calon TKI/TKI antara lain: (a) mentaati peraturan perundangundangan baik di dalam negeri maupun di negara tujuan; (b) mentaati dan melaksanakan pekerjaannya sesuai dengan perjanjian kerja; (c) membayar biaya pelayanan penempatan TKI di luar negeri sesuai dengan peraturan perundang-undangan; dan (d) memberitahukan atau melaporkan kedatangan keberadaan dan kepulangan TKI kepada perwakilan Republik Indonesia di negara tujuan.

Perlindungan hak pekerja migran, utamanya pekerja migran Indonesia sangat erat dengan Hak Asasi Manusia (HAM) yang diakui secara nasional maupun internasional. Konstitusi Indonesia dalam Undang-Undang Dasar Negara Republik Indonesia (UUD NRI) 1945 Pasal 27 Ayat 2 yang menyatakan jaminan terhadap hak setiap warga negara untuk memperoleh pekerjaan. Hal ini kemudian dipertegas dalam UUD 1945 (hasil amandemen kedua) Bab XA tentang Hak Asasi Manusia (Pasal 28A-28J). Pasal 28 D mengamanatkan bahwa "setiap orang berhak untuk bekerja serta mendapatkan imbalan dan perlakuan yan adil dan layak dalam hubungan kerja".

Selanjutnya dalam pasal 28 I ayat 4 menegaskan bahwa perlindungan (protection), pemajuan (furtherance), penegakan (enforcement), dan pemenuhan (fulfillment) hak asasi manusia adalah tanggungjawab negara dalam hal ini pemerintah. Selanjutnya, UU No. 29 
Tahun 1999 tentang Hak Asasi Manusia (HAM) dalam Pasal 39 ayat 2 juga menyatakan bahwa: "setiap orang berhak dengan bebas memilih pekerjaan yang disukainya dan berhak pula atas syarat-syarat ketenagakerjaan yang adil". Hal ini berimplikasi kepada pemerintah (negara) untuk hadir dalam proses migrasi pekerja Indonesia ke luar negeri.

Berdasarkan pemaparan di atas dapat dipahami bahwa pekerja migran Indonesia atau tenaga kerja Indonesia di luar negeri telah diatur dalam Undang-Undang Nomor 39 Tahun 2004 tentang Penempatan dan Perlindungan Tenaga Kerja Indonesia di Luar Negeri. Namun demikian Undang-Undang tersebut masih dianggap belum mampu untuk memberikan perlindungan menyeluruh bagi pekerja migran Indonesia.

\section{Pekerja Migran dalam Hukum Internasional}

Bagian sebelumnya tentang pekerja migran Indonesia dalam Undang-Undang Nomor 39 Tahun 2004 telah dijelaskan bahwa hukum nasional dan hukum internasional merupakan instrumen dalam perlindungan hak pekerja migran, termasuk pekerja migran Indonesia. Hal ini ditegaskan dalam pasal pasal 71 UU No. 29 Tahun 1999 tentang Hak Asasi Manusia (HAM) yang mengatur mengenai tanggungjawab pemerintah untuk menghormati, melindungi, menegakkan, dan memajukan hak asasi manusia baik yang diatur dalam undang-undang maupun hukum internasional. Sehingga hukum internasional juga patut menjadi acuan dalam konteks pemajuan perlindungan TKI. 
Bustamante (2002) dalam Pranoto (2011:6) menyatakan bahwa penggunaan hukum internasional dalam perlindungan PMI/TKI tidak bisa dilepaskan dari fakta-fakta yang menunjukkan akan pemberian hak khusus bagi para pekerja migran di mata masyarakat internasional. Dalam kaitannya dengan itu, Antoine Pécoud dan Paul deGuchteneire memandang stagnasi yang ada lebih disebabkan karena ketidaan kehendak politik semata. Oleh karenanya sangatlah tepat apabila kita hendak memajukan perlindungan hukum bagi pekerja migran untuk mulai secara serius mempertimbangkan pemanfaatan terhadap hukum internasional. ${ }^{39}$

Pranoto (2011:7-8) menyatakan bahwa ia mendorong semua pihak untuk secara serius mempertimbangkan pemanfaatan hukum HAM internasional bagi pemajuan HAM, khususnya bagi pekerja migran Indonesia (atau yang lebih dikenal sebagai Tenaga Kerja Indonesia atau TKI) dan penciptaan sebuah manajemen migrasi yang baik. Usulan ini tidak bisa dilepaskan dari fakta yang menunjukkan bahwa baik pemerintah Indonesia maupun para pihak yang terlibat dalam advokasinya belum mampu memanfaatkannya secara maksimal. Hal yang terjadi justru sebaliknya, mereka cenderung menaruh curiga yang berlebih-lebihan terhadap hukum internasional. Padahal pemanfaatan hukum internasional oleh para advokat HAM pekerja migran di negara-negara lain telah menjadi pilihan utama dalam perjuangannya. Padahal secara legal-formal pemanfaatan mekanisme hukum internasional telah diakui sebagai HAM

39 Pranoto Iskandar (ed.), (2011), Standar Internasional Migrasi Ketenagakerjaan Berbasis HAM, Cianjur: IMR Press, h. 6. 
oleh hukum nasional. Dengan kata lain, diabaikannya pemanfaatan mekanisme internasional yang seakan dilakukan secara sistematis bisa disamakan sebagai pelanggaran HAM serius. ${ }^{40}$ Ismantoro (2011:167-168) juga menyatakan bahwa pemerintah Indonesia dalam melakukan pembaruan hukum tentang TKI juga harus berpedoman dengan hukum internasional, yakni nilai-nilai konvensi internasional yang berkaitan dengan perlindungan terhadap pekerja migran dan keluarganya. ${ }^{41}$

Hukum substantif bagi perlindungan pekerja migran dalam hukum internasional menurut Pranoto (2011:44) perlu memperhatikan prinsip dasar dalam sistem perlindungan internasional bagi pekerja migran di mana negara dimungkinkan untuk menolak memberikan pekerjaan kepada bukan warga negaranya, tetapi "ketika hubungan kerja telah tercipta, maka semua orang berhak atas hak-hak pekerja dan kepegawaian". Berikut adalah daftar hak-hak yang dimiliki oleh para pekerja migran sesuai dengan hukum internasional. ${ }^{42}$

Hak-Hak Dasar meliputi:

1) Perlindungan yang sama di depan hukum dan tidak ada pembatasan terhadap kebanyakan hak-hak sipil dan politik tanpa mempertimbangkan "status lainnya", termasuk status tak berdokumen;

2) Kewajiban untuk menghormati dan menjalankan HAM tanpa... status keimigrasian seseorang;

\footnotetext{
${ }^{40}$ Ibid. hh. 7-8.

${ }^{41}$ Ismantoro Dwi Yuwono, (2011), Hak dan Kewajiban Tenaga Kerja Indonesia di Luar Negeri, Yogyakarta: Penerbit Pustaka Yustisia, hh. 167-168.

42 lbid. h. 44.
} 
3) Hak atas "upaya hukum efektif" bagi pelanggaran-pelanggaran HAM dan atas "perimbangan secara adil oleh sebuah peradilan yang kompeten, independen dan imparsial ... untuk menentukan hak-hak dan kewajiban-kewajiban ... terkait dengan hakikat kesipilannya [atau] pekerjaan;

4) Pelarangan atas kerja paksa;

5) Gaji yang sepadan dengan pekerjaan dan bayaran yang setara dengan kerja "tanpa dibeda-bedakan";

6) Kebebasan untuk berkelompok, berserikat dan menegosiasikan hak, termasuk memperoleh upaya hukum atas pelanggarannya;

7) Lembur dan sebuah hari kerja dengan waktu yang masuk akal;

8) Hari libur periodik dengan bayaran;

9) Kondisi kerja yang layak, termasuk perlindungan atas keselamatan dan kesehatan;

10)Kompensasi bagi para pekerja migrant dan perlindungan kesehatan bagi para pekerja migran yang mengalami kecelakaan;

11)Perbaikan atas segala aspek kebersihan industrial dan pencegahan atas penyakit akibat pekerjaan;

12)Tersedianya "jaminan judicial dan administratif" dan upaya hukum yang efektif bagi segala pelanggaran yang terjadi;

13)Keikutsertaan dalam skema jaminan sosial atau hak untuk mendapat kontribusi jaminan sosial; 
14)Kewajiban negara penerima untuk mengambil langkah "pencegahan dan perbaikan atas persoalan serius akibat ... belitan hutang";

15)Kewajiban negara penerima untuk melakukan tindakan-tindakan khusus "untuk mencegah dan memperbaiki persoalan serius terkait dengan ... penahanan paspor";

16) Kewajiban negara penerima untuk mengambil langkah-langkah khusus "untuk mencegah dan memperbaiki persoalan serius terkait dengan ... penahanan ilegal oleh majikan atau pemberi kerja;

17)Kewajiban negara penerima untuk mengambil langkah-langkah khusus "untuk mencegah dan memperbaiki persoalan serius terkait ... pemerkosaan dan penyerangan fisik";

18)Kewajiban negara penerima untuk mencegah diskriminasi dalam rangka bekerja;

19)Bagi korban penjualan manusia "layanan konseling dan informasi”, khususnya terkait dengan hak-haknya dalam bahasa yang dimengerti dan ... kesempatan untuk memperoleh pelatihan, pendidikan dan pekerjaan;

20)Bagi korban penjualan manusia, status hukum keimigrasiannya didasarkan pada traum yang mereka derita dan padaa saat pemulangannya dituntut kerjasama dengan pejabat penegak 
hukum untuk penanganan atas kejahatan yang mana ia merupakan korbannya. ${ }^{43}$

Hak-Hak Tambahan bagi Pekerja Migran Berdokumen meliputi:

1) Kewenangan untuk memilih/merubah pekerjaan tanpa kehilangan statusnya (kurang dinyatakan secara tegas);

2) Tidak kehilangan status dan izin kerja hanya dikarenakan kehilangan pekerjaan;

3) Hak untuk bekerja bagi para anggota keluarganya (dinyatakan secara tidak tegas);

4) Unifikasi keluarga (dinyatakan secara tidak tegas);

5) Asuransi pengangguran (didasarkan pada pertimbangan nasionalitas) dan "skema kerja publik" (didasarkan pada pertimbangan nasionalitas). ${ }^{44}$

Selain hak-hak yang telah dipaparkan di atas, hukum internasional yang menetapkan standar-standar yang menciptakan suatu model bagi hukum-hukum serta prosedur administrasi dan peradilan masing-masing negara diatur dalam Konvensi Internasional Perlindungan Hak-Hak Pekerja Migran (International Convention of the Protection of the Rights of All Migrant Workers and Members of their Families). Setiap negara yang meratifikasi konvensi ini dikenai kewajiban untuk menetapkan langkahlangkah guna menjamin bahwa pekerja migran dilindungi hak-haknya dan dapat mencari upaya penyelesaian bila hak tersebut dilanggar. Indonesia menjadi negara pihak Konvensi ini setelah melalui proses panjang yakni

${ }^{43}$ Ibid. hh. 44-48.

44 lbid. h. 49. 
penandatanganan pada 22 September 2004, pembahasan di Dewan Perwakilan Rakyat (DPR) Republik Indonesia pada 9 dan 12 April 2012. Konvensi ini ditandatangani oleh Presiden Susilo Bambang Yudhoyono pada 2 Mei 2012 menjadi UU No. 6 Tahun 2012 tentang pengesahan International Convention on the Protection of The Rights Of All Migrant Workers and Members of Their Families (Konvensi Internasional mengenai Perlindungan Hak-Hak Seluruh Pekerja Migran dan Anggota Keluarganya). Perserikatan Bangsa-Bangsa (PBB) menerima dokumen hasil ratifikasi Indonesia pada 31 Mei 2012.

Menurut Pranoto (2011:43) nilai penting Konvensi tersebut mengandung 7 fitur antara lain: (1) langkah awal bagi perlindungan HAM dasar; (2) menawarkan pendekatan HAM dalam isu pekerja migran; (3) mengangkat situasi buruk yang dihadapi oleh sebagian pekerja migran; (4) bersifat komprehensif mulai dari pembahasan sampai pemulangan; (5) pengakuan secara tegas akan HAM para migran tanpa mempertimbangkan status migrasinya; (6) memuat pengertian-pengertian yang telah diakui secara internasional; dan (7) memiliki komite khusus yang ditujukan untuk menangani isu pekerja migran. ${ }^{45}$

Komitmen untuk pemenuhan hak-hak di atas semakin diperkuat dalam UN Summit for Refugees and Migrants pada 19 September 2016 yang menghasilkan deklarasi politik bernama New York Declaration. Deklarasi ini juga memuat komitmen bagi pekerja migran antara lain:

"We will consider facilitating opportunities for safe, orderly and regular migration, including, as appropriate, employment creation,

${ }^{45}$ Pranoto Iskandar (ed.), op.cit. h. 43. 
labour mobility at all skills levels, circular migration, family reunification and education-related opportunities. We will pay particular attention to the application of minimum labour standards for migrant workers regardless of their status, as well as to recruitment and other migration-related costs, remittance flows, transfers of skills and knowledge and the creation of employment opportunities for young people". (Part 3 about commitments for migrants Number 57$)^{46}$

Komitmen di atas menyatakan bahwa pihak yang berkomitmen akan mempertimbangkan untuk memfasilitasi peluang untuk keamanan, ketertiban dan migrasi regular, termasuk kesesuaian, penciptaan lapangan kerja, mobilitas pekerja di segala jenjang kemampuan, migrasi sirkuler, reunifikasi keluarga dan peluang berbasis pendidikan. Komitmen ini juga menegaskan perhatian khusus terhadap pengajuan standar minimum pekerja untuk pekerja migran tanpa memandang status, perekrutan dan biaya terkait migrasi lainnya, arus pengiriman uang, transfer kemampuan dan pengetahuan, dan penciptaan kesempatan kerja bagi pemuda.

Selain itu, komitmen terhadap pekerja migran juga ditunjukkan pada lampiran 2 dari deklarasi tersebut mengenai "towards a global compact for safe, orderly and regular migration". Pada bagian III poin 8 huruf q dinyatakan bahwa:

"Protection of labour rights and a safe environment for migrant workers and those in precarious employment, protection of women migrant workers in all sectors and promotion of labour mobility, including circular migration".

Poin di atas menyatakan bahwa perlindungan hak-hak pekerja migrant dan lingkungan yang aman bagi pekerja migran dan orang-orang

\footnotetext{
${ }^{46}$ United Nations, (2016), New York Declarations - UN Summit for Refugees and Migrants - http://refugeesmigrants.un.org/declaration, diakses pada 19 Desember 2016.
} 
dalam pekerjaan berbahaya, perlindungan terhadap pekerja migran perempuan di semua sektor dan promosi mobilitas pekerja, termasuk migrasi sirkuler. Hal di atas menunjukkan bahwa dunia internasional telah menempatkan pekerja migran dalam posisi yang mendapatkan perhatian khusus.

Posisi pekerja migran Indonesia dalam hukum internasional juga akan menjadi acuan peneliti untuk menentukan substansi dalam konvensi internasional perlindungan hak pekerja migran mana saja yang diadopsi ke dalam UU No. 39 Tahun 2004 sehingga standar internasional dapat diterapkan dalam upaya perlindungan pekerja migran Indonesia.

\section{B. Kerangka Konseptual}

Harmonisasi hukum dalam penelitian ini dimaknai sebagai upaya penyelarasan konvensi internasional perlindungan hak pekerja migran yang telah diratifikasi dalam UU No. 6 Tahun 2012 tentang pengesahan International Convention on the Protection of The Rights Of All Migrant Workers and Members of Their Families (Konvensi Internasional mengenai Perlindungan Hak-Hak Seluruh Pekerja Migran dan Anggota Keluarganya) dengan Undang-Undang Nomor 39 Tahun 2004 tentang Penempatan dan Perlindungan Tenaga Kerja Indonesia di Luar Negeri (PPTKILN). Konvensi internasional perlindungan hak pekerja migran ini merupakan salah satu instrumen internasional yang mengatur urusan pekerja migran secara komprehensif. Sehingga nilai-nilai yang terkandung dalam Konvensi dapat diharmonisasi ke dalam hukum nasional Indonesia di bidang ketenagakerjaan, khususnya bidang migrasi kerja. 
Berdasarkan kriteria secara internasional (Konvensi Wina 1969) dan nasional (UU No. 24 Tahun 2000), konvensi internasional perlindungan hak pekerja migran termasuk ke dalam kategori perjanjian internasional (konvensi). Hal ini menegaskan bahwa konvensi internasional ini patut menjadi rujukan bagi Indonesia untuk pengembangan sistem perlindungan pekerja migran Indonesia dalam UU No. 39 Tahun 2004.

Teori yang digunakan untuk menjelaskan proses harmonisasi tersebut yakni teori hubungan perjanjian internasional dengan hukum nasional. Teori ini akan mengurai bagaimana harmonisasi konvensi internasional perlindungan hak pekerja migran dengan UU No. 39 Tahun 2004 tentang Penempatan dan Perlindungan Tenaga Kerja Indonesia di Luar Negeri (PPTKILN) yang saat ini sedang direvisi melalui Rancangan Undang-Undang Perlindungan Pekerja Migran Indonesia.

Lebih lanjut, pekerja migran Indonesia atau tenaga kerja Indonesia berdasarkan UU No. 39 Tahun 2004 tentang Penempatan dan Perlindungan Tenaga Kerja Indonesia di Luar Negeri (PPTKILN) adalah warga negara Indonesia dengan kriteria: (1) memenuhi syarat untuk bekerja di luar negeri, (2) hubungan kerja untuk jangka waktu tertentu dan (3) menerima upah. Pekerja migran Indonesia ini memiliki posisi dalam hukum nasional (UU No. 39 Tahun 2004) dan hukum internasional. Ketentuan-ketentuan dalam hukum nasional maupun internasional tersebut menjadi acuan peneliti untuk menentukan substansi dalam konvensi internasional perlindungan hak pekerja migran mana saja yang 
perlu diadopsi ke dalam UU No. 39 Tahun 2004, sehingga standar internasional dapat diterapkan dalam upaya perlindungan pekerja migran Indonesia.

\section{Diagram Kerangka Konseptual}

Berdasarkan uraian di atas, maka kerangka pikir penelitian ini sebagai berikut:

Bagan 2.1 Diagram Kerangka Konseptual Harmonisasi Konvensi Internasional Perlindungan Hak Pekerja Migran dengan Undang-Undang Nomor 39 Tahun 2004

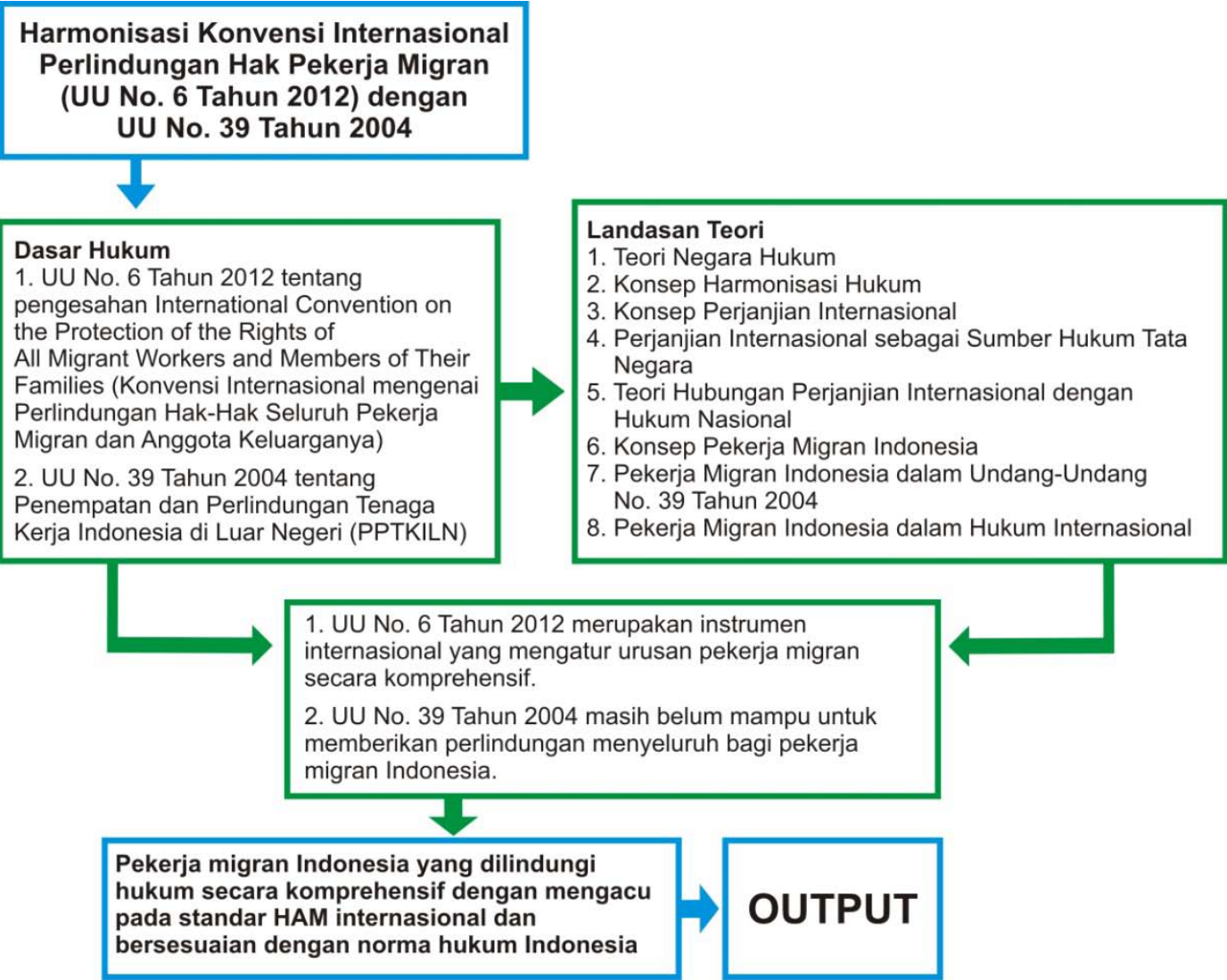

\section{Definisi Operasional}

Definisi operasional dalam penelitian ini sebagai berikut:

a. Harmonisasi hukum adalah upaya atau proses penyesuaian asas dan sistem hukum, agar terwujud kesederhanaan hukum, kepastian hukum dan keadilan. 
b. Perjanjian Internasional (konvensi) adalah setiap perjanjian di bidang hukum publik, yang diatur oleh hukum internasional dan dibuat oleh Pemerintah dengan Negara, organisasi internasional atau subjek hukum internasional lain.

c. Pekerja migran adalah seseorang yang akan, tengah, atau telah melakukan aktivitas yang dibayar di suatu Negara di mana ia bukan merupakan warga negara.

d. Negara asal adalah negara dimana orang yang bersangkutan merupakan warga Negara.

e. Negara tujuan kerja adalah negara dimana pekerja migran akan, tengah atau telah melakukan aktivitas yang dibayar, sebagaimana adanya.

f. Negara transit adalah negara yang disinggahi oleh orang yang bersangkutan dalam perjalanan ke negara tujuan kerja atau dari negara tujuan kerja ke negara asal atau tempat tinggalnya.

g. Undang-Undang adalah hukum yang telah disahkan oleh badan legislatif atau unsur pemerintahan yang lainnya.

h. Pekerja migran Indonesia/tenaga kerja Indonesia adalah setiap warga negara Indonesia yang memenuhi syarat untuk bekerja di luar negeri dalam hubungan kerja untuk jangka waktu tertentu dengan menerima upah.

i. Calon pekerja migran Indonesia/calon tenaga kerja Indonesia adalah setiap warga negara Indonesia yang memenuhi syarat sebagai pencari kerja yang akan bekerja di luar negeri dan terdaftar di instansi 
pemerintah kabupaten/kota yang bertanggung jawab di bidang ketenagakerjaan.

j. Penempatan PMI/TKI adalah kegiatan pelayanan untuk mempertemukan TKI sesuai bakat, minat, dan kemampuannya dengan pemberi kerja di luar negeri yang meliputi keseluruhan proses perekrutan, pengurusan dokumen, pendidikan dan pelatihan, penampungan, persiapan pemberangkatan, pemberangkatan sampai ke negara tujuan, dan pemulangan dari negara tujuan.

k. Perlindungan PMI/TKI adalah segala upaya untuk melindungi kepentingan calon TKI/TKI dalam mewujudkan terjaminnya pemenuhan hak haknya sesuai dengan peraturan perundang undangan, baik sebelum, selama, maupun sesudah bekerja. 


\section{BAB III \\ METODE PENELITIAN}

\section{A. Tipe Penelitian}

Penelitian ini termasuk dalam tipe penelitian hukum normatif atau penelitian hukum doktrinal. yaitu penelitian hukum yang mempergunakan sumber data sekunder atau merupakan penelitian kepustakaan, yaitu penelitian terhadap data sekunder. Pada penelitian hukum jenis ini, hukum dikonsepkan sebagai apa yang tertulis dalam peraturan perundangundangan (law in books) atau hukum dikonsepkan sebagai kaidah atau norma yang merupakan patokan berperilaku manusia yang dianggap pantas. ${ }^{1}$

Lebih lanjut penelitian hukum normatif ini terbagi ke dalam 7 jenis, salah satunya adalah penelitian terhadap taraf sinkronisasi vertikal dan horizontal. Penelitian jenis ini bertujuan untuk mengungkapkan kenyataan sampai sejauh manakah suatu perundang-undangan tertentu itu serasi secara vertikal atau serasi secara horizontal, apabila perundangundangan tersebut adalah sederajat dan termasuk bidang yang sama. Jika yang dilakukan adalah penelitian terhadap taraf sinkronisasi vertikal, maka yang termasuk dalam ruang lingkupnya adalah berbagai perundangundangan yang derajatnya berbeda-beda yang mengatur bidang yang sama. Untuk dapat melakukan penelitian taraf sinkronisasi, lebih dahulu harus dilakukan inventarisasi untuk diteliti. ${ }^{2}$

${ }^{1}$ Said Sampara dan La Ode Husen, (2016), Metode Penelitian Hukum Edisi Revisi, Makassar: Kretakupa Print. h. 39.

${ }^{2}$ Ibid. hh. 54-55 
Penelitian mengenai harmonisasi konvensi internasional perlindungan hak pekerja migran dengan Undang-Undang No. 39 Tahun 2004 termasuk ke dalam jenis penelitian terhadap taraf sinkronisasi vertikal dan horizontal. Hal ini sejalan dengan konsep harmonisasi hukum yang bertujuan agar hukum menjadi selaras dan serasi. Sebelum diteliti lebih lanjut, terlebih dahulu dilakukan inventarisasi dilakukan terhadap peraturan perundang-undangan yang terkait dengan pekerja migran Indonesia.

\section{B. Jenis dan Bahan Sumber Hukum}

Dalam proses pengumpulan bahan hukum, peneliti menggunakan jenis data sekunder. Adapun data sekunder di bidang hukum (dipandang dari sudut kekuatan mengikatnya) dapat dibedakan menjadi:

(a) Bahan-bahan hukum primer, yaitu bahan-bahan hukum yang mengikat terdiri atas:

1. Norma atau kaidah dasar yaitu pembukaan Undang-Undang Dasar Negara Republik Indonesia Tahun 1945;

2. Peraturan dasar, yaitu batang tubuh Undang-Undang Dasar Negara Republik Indonesia Tahun 1945;

3. Peraturan Perundang-undangan;

4. Bahan hukum yang tidak dikodifikasikan, misalnya hukum adat;

5. Yurisprudensi;

6. Traktat. 
(b) Bahan-bahan hukum sekunder yaitu bahan yang memberikan penjelasan mengenai bahan hukum primer dan dapat membantu menganalisis dan memahami bahan hukum primer adalah: (1) Rancangan peraturan-peraturan perundangundangan; (2) hasil karya ilmiah para sarjana; dan (3) hasil-hasil penelitian.

(c) Bahan-bahan hukum tersier yaitu bahan-bahan yang memberikan informasi tentang bahan hukum primer dan bahan hukum sekunder, misalnya: (1) kamus (hukum); dan (2) ensiklopedia. $^{3}$

Dalam penelitian ini, bahan-bahan hukum primer meliputi: Konvensi Internasional Perlindungan Hak Pekerja Migran yang telah diratifikasi melalui UU No. 6 Tahun 2012 tentang pengesahan International Convention on the Protection of The Rights Of All Migrant Workers and Members of Their Families (Konvensi Internasional mengenai Perlindungan Hak-Hak Seluruh Pekerja Migran dan Anggota Keluarganya), dan Undang-Undang No. 39 Tahun 2004 tentang Penempatan dan Perlindungan Tenaga Kerja Indonesia di Luar Negeri (PPTKILN). Sedangkan bahan hukum sekunder yaitu Rancangan Undang-Undang Perlindungan Pekerja Migran Indonesia dan naskah akademiknya, serta hasil-hasil penelitian terkait harmonisasi hukum dan konvensi internasional. Sedangkan bahan hukum tersier yang digunakan yakni Kamus Hukum HAM Internasional.

${ }^{3}$ Ibid. hh. 39-40. 


\section{Teknik Pengumpulan Data}

Menurut Silalahi (2012:280), data merupakan bahan penting yang digunakan oleh peneliti untuk menjawab pertanyaan atau menguji hipotesis dan mencapai tujuan penelitian. Oleh karena itu, data dan kualitas data merupakan pokok penting dalam penelitian karena menentukan kualitas hasil penelitian. Data diperoleh melalui suatu proses yang disebut pengumpulan data. Pengumpulan data dapat didefinisikan sebagai satu proses mendapatkan data empiris melalui responden dengan menggunakan metode tertentu. ${ }^{4}$

Pengumpulan data dalam penelitian ini dilakukan dengan studi kepustakaan (library research). Studi kepustakaan adalah pengkajian informasi tertulis mengenai hukum yang berasal dari berbagai sumber dan dipublikasikan secara luas serta dibutuhkan dalam penelitian hukum normatif yakni penulisan yang didasarkan pada data-data yang dijadikan objek penelitian, seperti peraturan perundang-undangan, buku-buku referensi, majalah, artikel, surat kabar, buletin tentang segala permasalahan yang sesuai dengan penelitian ini yang akan disusun dan dikaji secara komprehensif. Selain itu, penelitian ini juga mendapatkan penguatan dengan melakukan wawancara (interview) dengan informan dari Kementerian Ketenagakerjaan RI dan Badan Nasional Penempatan dan Perlindungan Tenaga Kerja Indonesia (BNP2TKI).

\footnotetext{
${ }^{4}$ Ulber Silalahi, (2012), Metode Penelitian Sosial, Bandung: PT. Refika Aditama, h. 280.
} 


\section{Teknik Analisis Data}

Analisis data adalah proses penyederhanaan data dan penyajian data dengan mengelompokkannya dalam suatu bentuk yang mudah dibaca dan diinterpretasi. Menurut Nan Lin (1976) dalam Silalahi (2012:332), analisis data mempunyai dua tujuan yakni meringkas dan menggambarkan data (to summarize and describe the data) dan membuat inferensi dari data untuk populasi darimana sampel ditarik (to make inferences from the data to the population from which the sample was drawn). Kerlinger dalam Silalahi (2012:332) menyatakan analisis berarti kategorisasi, penataan, manipulasi dan peringkatan data untuk memperoleh jawaban atas pertanyaan penelitian. Kegunaan analisis ialah mereduksikan data menjadi perwujudan yang dapat dipahami dan ditafsir dengan cara tertentu hingga relasi masalah penelitian dapat ditelaah serta diuji..$^{5}$

Teknik analisis data dalam penelitian ini menggunakan analisis data kualitatif. Analisis data kualitatif dilakukan apabila data empiris yang diperoleh adalah data kualitatif berupa kumpulan berwujud kata-kata dan bukan rangkaian angka serta tidak dapat disusun dalam kategorikategori/struktur klasifikasi. Data (dalam wujud kata-kata) mungkin telah dikumpulkan dalam aneka cara (observasi, wawancara, intisari dokumen, pita rekaman) dan biasanya "diproses" sebelum siap digunakan (melalui pencatatan, pengetikan, penyuntingan atau alih-tulis), tetapi analisis kualitatif tetap menggunakan kata-kata yang biasanya disusun ke dalam

${ }^{5}$ Ibid, hh. 331-332. 
teks yang diperluas, dan tidak menggunakan perhitungan matematis atau statistika sebagai alat bantu analisis. $^{6}$

Menurut Miles dan Huberman dalam Silalahi (2012:339), kegiatan analisis terdiri dari tiga alur kegiatan yang terjadi secara bersamaan, yaitu reduksi data, penyajian data, dan penarikan kesimpulan/verifikasi. Terjadi bersamaan berarti reduksi data, penyajian data dan penarikan kesimpulan/verifikasi sebagai sesuatu yang jalin menjalin merupakan proses siklus dan interaktif pada saat sebelum, selama dan sesudah pengumpulan data dalam bentuk sejajar untuk membangun wawasan umum yang disebut "analisis".

Bagan 3.1 Komponen-Komponen Analisis Data: Model Interaktif

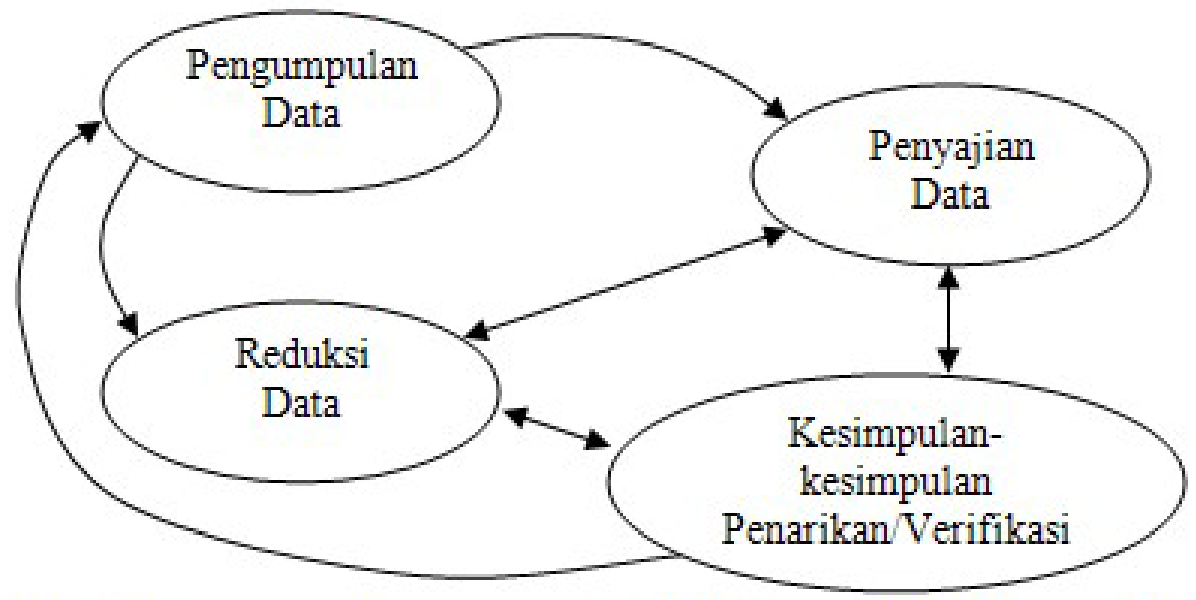

Sumber: Miles dan Huberman (1992:20) dalam Silalahi (2012:340)

Bagan 3.1 di atas merupakan komponen-komponen analisis data dengan model interaktif yang digunakan dalam penelitian ini. Deskripsi reduksi data, penyajian data dan menarik kesimpulan dijelaskan sebagai berikut:

${ }^{6}$ Ibid, h. 339. 


\section{Reduksi Data}

Reduksi data merupakan suatu bentuk analisis yang menajamkan, menggolongkan, mengarahkan, membuang yang tidak perlu, dan mengorganisasi data sedemikian rupa sehingga kesimpulan-kesimpulan finalnya dapat ditarik dan diverifikasi. Reduksi data atau proses transformasi ini berlanjut terus sesudah pengumpulan data, sampai laporan akhir lengkap tersusun. Jadi dalam penelitian kualitatif, "reduksi data" tidak perlu mengartikannya sebagai kuantifikasi. Data kualitatif dapat disederhanakan dan ditransformasikan dalam aneka macam cara: melalui seleksi ketat, melalui ringkasan atau uraian singkat, menggolongkan dalam suatu pola yang lebih luas dan sebagainya. ${ }^{7}$

Langkah-langkah yang ditempuh dalam mereduksi data studi pustaka yakni hasil pengumpulan data kepustakaan diinventaris/dikumpulkan. Selanjutnya dilakukan proses pembersihan dengan data-data yang diperoleh dengan cara, membaca ulang dokumen beberapa kali dan meminta bantuan rekan sejawat untuk ikut membaca.

\section{Penyajian Data}

Penyajian data merupakan alur kedua yang penting dalam kegiatan analisis data kualitatif. Penyajian data yaitu sekumpulan informasi tersusun yang memberi kemungkinan adanya penarikan kesimpulan dan pengambilan tindakan. Melalui data yang disajikan, kita melihat dan akan dapat memahami apa yang sedang terjadi dan apa yang harus dilakukan-

${ }^{7}$ Ibid. hh. 339-340. 
lebih jauh menganalisis ataukah mengambil tindakan berdasarkan atas pemahaman yang didapat dari penyajian-penyajian tersebut. ${ }^{8}$

Penyajian data penelitian ini menempatkan data hasil telaah pustaka pada posisinya sesuai dengan kerangka hasil dan pembahasan yang disusun mengacu pada rumusan masalah yakni harmonisasi konvensi internasional perlindungan hak pekerja migran dengan UndangUndang No. 39 Tahun 2004.

\section{Penarikan Kesimpulan}

Kegiatan analisis yang ketiga adalah menarik kesimpulan dan verifikasi. Ketika kegiatan pengumpulan data dilakukan, seorang penganalisis kualitatif mulai mencari arti benda-benda, mencatat keteraturan, pola-pola, penjelasan, konfigurasi-konfigurasi yang mungkin, alur sebab akibat dan proposisi. Mula-mula kesimpulan belum jelas, tetapi kemudian kian meningkat menjadi lebih terperinci. Kesimpulankesimpulan "final" mungkin tidak muncul sampai pengumpulan data berakhir, bergantung pada besarnya kumpulan-kumpulan catatan lapangan, pengkodeannya, penyimpanan dan metode pencarian ulang yang digunakan, kecakapan peneliti, dan tuntutan pemberi dana, tetapi seringkali kesimpulan itu telah dirumuskan sejak awal, sekalipun seorang peneliti menyatakan telah melanjutkanya "secara induktif". ${ }^{9}$

Kesimpulan-kesimpulan diverifikasi selama penelitian berlangsung. Verifikasi itu mungkin sesingkat pemikiran kembali yang melintas dalam pikiran penganalisis selama dia menulis, suatu tinjauan ulang pada catatan-catatan atau mungkin begitu seksama dengan peninjauan kembali untuk mengembangkan "kesepakatan intersubjektif". Singkatnya, makna-

\footnotetext{
${ }^{8}$ Ibid. h. 340

${ }^{9}$ lbid.
} 
makna yang muncul dari data harus diuji kebenarannya, kekukuhannya dan kecocokannya yakni merupakan validitasnya. Jika tidak demikian, yang kita miliki adalah cita-cita yang menarik mengenai sesuatu yang terjadi dan yang tidak jelas kebenarannya dan kegunaannya. ${ }^{10}$

Proses penarikan kesimpulan dalam penelitian ini dilakukan dari kumpulan data dan informasi yang diolah dan dianalisa dengan melihat bagaimana harmonisasi konvensi internasional perlindungan hak pekerja migran dengan UU No. 39 Tahun 2004 dan bagaimana substansi konvensi internasional perlindungan hak pekerja migran diadopsi ke dalam UU No. 39 Tahun 2004 yang disimpulkan berdasarkan data yang telah dianalisis dari sumber data sekunder.

${ }^{10}$ lbid. 


\section{BAB IV}

\section{HASIL DAN PEMBAHASAN}

\section{A. Harmonisasi Konvensi Internasional Perlindungan Hak Pekerja}

\section{Migran dengan UU No. 39 Tahun 2004}

Indonesia sebagai negara berdaulat merupakan subjek utama dalam hukum internasional. Negara sebagai subjek hukum internasional berperan secara dominan dalam hubungan internasional yang merupakan aktor sentral dalam melahirkan prinsip-prinsip dan kaidah-kaidah hukum internasional. Selain itu, Indonesia juga menjalankan negara hukum dalam sistem ketatanegaraan berlandaskan pada Pasal 1 ayat (3) UUD NRI 1945 yang menyatakan bahwa "negara Indonesia adalah negara hukum". Negara hukum yang dijalankan Indonesia adalah negara hukum Pancasila. Walau demikian, negara hukum yang dijalankan Indonesia tidak terlepas dari pengaruh negara hukum yang telah diterapkan oleh negara lainnya seperti: Rechsstaat, the Rule of Law, Nomokrasi Islam bahkan Socialist Legality. Namun demikian, kesamaan yang hampir dimiliki oleh kelimanya adalah penghargaan terhadap hak asasi manusia.

Konvensi Internasional Perlindungan Hak Pekerja Migran merupakan hasil konsensus dari negara-negara anggota Perserikatan Bangsa-Bangsa (PBB) yang memiliki anggota dari sistam hukum dan sistem sosial yang beragam. Namun sebagaimana telah dijelaskan di atas bahwa walaupun tipe negara hukum yang dijalankan beragam, tetapi memiliki kesamaan dalam merespon hak asasi manusia. Sehingga, konvensi internasional dapat diterima atau diadaptasi ke dalam sistem hukum nasional negara-negara anggotanya, termasuk Indonesia. 
Jika hukum internasional dilihat dalam perspektif Islam, Muhammad Abu Zahrah dalam bukunya Hubungan-Hubungan Internasional dalam Islam yang telah dialihbahasakan oleh Muhammad Zein Hassan memandang bahwa:

"Hukum internasional yang berlaku sekarang lahir dari kebiasaankebiasaan yang berlaku antara negara dan dari perjanjianperjanjian yang mengikat negara-negara itu. Demikian pula kekuatan-kekuatannya. Maka perjanjian-perjanjian yang ada antara mereka berperan membina perundang-undangan itu. Adapun hukum (Islam) internasional mengambil kekuatannya dari dasar (prinsip-prinsip) kemanusiaan umum, termasuk dalamnya memenuhi janji. Oleh karena itu perjanjian-perjanjian yang berdasarkan keadilan, memainkan peranan besar dalam membentuk hukum (Islam) internasional itu". ${ }^{1}$

Pandangan di atas memberikan pemahaman bahwa hukum internasional dalam perspektif Islam pada dasarnya berdasar pada prinsip-prinsip kemanusiaan, termasuk didalamnya adalah seruan untuk memenuhi janji sebagaimana telah disepakati dalam perjanjian yang telah dibuat. Adapun keadilan harus menjadi dasar yang membentuk hukum/perjanjian internasional yang dibuat.

Allah SWT berfirman dalam surah An-Nisa ayat 135 mengenai perintah bagi orang-orang beriman untuk menegakkan keadilan, sebagai berikut:

\footnotetext{
${ }^{1}$ Muhammad Abu Zahrah, (1973), Hubungan-Hubungan Internasional dalam Islam, Jakarta: Penerbit Bulan Bintang. hh. 91-92.
} 


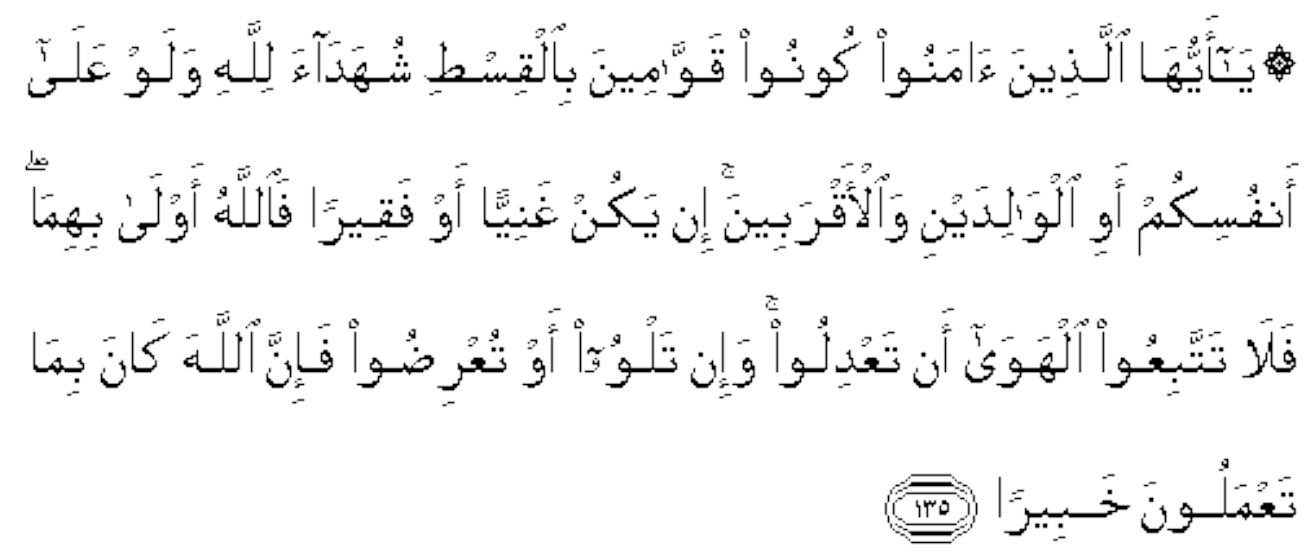

Artinya: Wahai orang-orang yang beriman, jadilah kamu orang yang benar-benar penegak keadilan, menjadi saksi karena Allah biarpun terhadap dirimu sendiri atau ibu bapa dan kaum kerabatmu. Jika ia kaya ataupun miskin, maka Allah lebih tahu kemaslahatannya. Maka janganlah kamu mengikuti hawa nafsu karena ingin menyimpang dari kebenaran. Dan jika kamu memutar balikkan (kata-kata) atau enggan menjadi saksi, maka sesungguhnya Allah adalah Maha Mengetahui segala apa yang kamu kerjakan.

Firman Allah SWT dalam surah An-Nisa ayat 135 di atas seyogyanya menjadi pedoman dalam menegakkan keadilan tanpa diskriminasi, karena sesungguhnya Allah SWT mengetahui segala sesuatu. Prinsip-prinsip dasar hukum internasional dalam Islam yang mengatur hubungan-hubungan antar bangsa/suku bangsa atau antar negara juga dinyatakan Allah SWT dalam surah AI-Hujurat ayat 13 sebagai berikut:

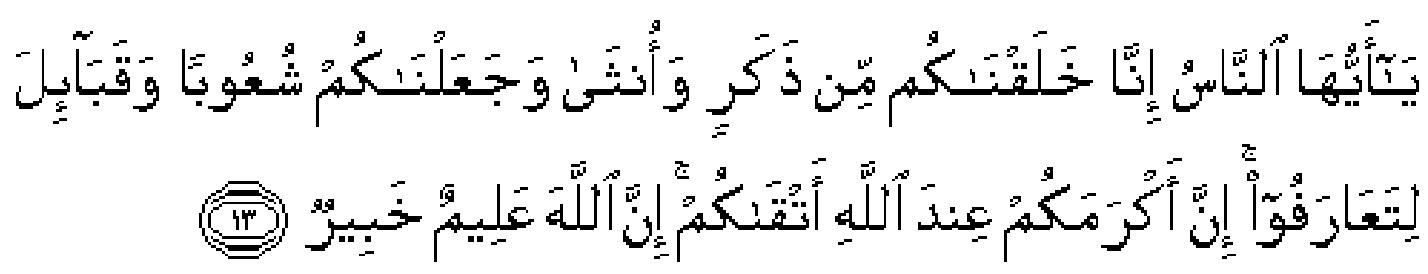

Artinya: Hai manusia, sesungguhnya Kami menciptakan kamu dari seorang laki-laki dan seorang perempuan dan menjadikan kamu berbangsa-bangsa dan bersuku-suku supaya kamu saling kenalmengenal. Sesungguhnya orang yang paling mulia diantara kamu disisi Allah ialah orang yang paling taqwa diantara kamu. Sesungguhnya Allah Maha Mengetahui lagi Maha Mengenal. 
Firman Allah SWT dalam surah Al-Hujurat ayat 13 dapat dimaknai bahwa di antara bangsa-bangsa dan suku-suku tersebut harus saling berhubungan/berinteraksi. Agar hubungan-hubungan tersebut berjalan secara harmonis dan damai tentu diperlukan aturan-aturan atau norma yang mendorong agar manusia atau bangsa/suku tersebut bertindak dan bertingkah-laku secara baik demi kepentingan mereka sendiri dan mencegah dari tindakan-tindakan yang tidak baik yang akan merugikan.

Muhammad Abu Zahrah menegaskan perspektif Al-Qur'an dalam perjanjian internasional (perjanjian-perjanjian) sebagai berikut:

"Kitab Al-Qur'an tidak mempergunakan pandangan demikian dalam mengadakan perjanjian-perjanjian. Al-Qur'an menyuruh memenuhi perjanjian sepenuh-penuhnya; dan tidak terikat oleh kuat atau lemahnya pihak-pihak yang berjanji, tetapi hanya terkait oleh pemenuhan janji pihak-pihak yang bersangkutan. Islam tidak menganggap pemenuhan janji sebagai penyelesaian sementara, tetapi untuk mengembangkan suasana damai yang tetap". ${ }^{2}$

Pandangan di atas menekankan pada dasarnya Al-Qur'an memerintahkan kepada para pihak yang mengadakan perjanjian untuk memenuhi janjinya sebagai upaya untuk mengembangkan suasana damai yang tetap. Suasana damai ini dapat diartikan sebagai tujuan dari perjanjian (internasional) yang dibuat untuk menyelesaikan permasalahan yang ditimbulkan akibat dari belum adanya pengaturan terhadap suatu hal. Dalam konteks penelitian ini yakni konvensi internasional perlindungan hak pekerja migran yang diharmonisasi dengan UU No. 39 Tahun 2004 diharapkan dapat menjadi solusi bagi penyelesaian permasalahan penempatan dan perlindungan TKI di luar negeri yang tentu

\footnotetext{
${ }^{2}$ Ibid. h. 92.
} 
berimplikasi terhadap kesejahteraan umat Islam yang merupakan agama dengan jumlah penganut terbesar di Indonesia.

Penjelasan di atas telah memberikan gambaran bahwa Indonesia sebagai negara berdaulat memegang peranan penting dalam subjek hukum internasional, demikian juga dengan kedudukan Indonesia sebagai negara hukum Pancasila sesuai amanat UUD NRI 1945. Hukum Internasional yang salah satu bentuknya adalah Konvensi Internasional sebagai hasil kesepakatan negara-negara juga telah mempertimbangan keberagaman negara-negara yang terlibat, sehingga Konvensi Internasional dapat diadaptasi dalam hukum nasional. Hal yang patut diperhatikan juga yakni landasan dari hukum internasional dalam perspektif Islam yakni hubungan yang dibangun atas dasar keadilan tanpa diskriminasi (Q.S An-Nisa ayat 135) dan membangun ukhuwah/kerjasama yang baik antar-negara (Q.S Al-Hujurat ayat 13).

Selanjutnya, Konvensi Internasional Perlindungan Hak Pekerja Migran yang telah diratifikasi oleh pemerintah Indonesia melalui UndangUndang Nomor 6 Tahun 2012 tentang pengesahan International Convention on the Protection of The Rights of All Migrant Workers and Members of Their Families (Konvensi Internasional mengenai Perlindungan Hak-Hak Seluruh Pekerja Migran dan Anggota Keluarganya). Ratifikasi atas konvensi ini berimplikasi terhadap tuntutan untuk melakukan harmonisasi terhadap hukum nasional, terutama yang berkaitan dengan penempatan dan perlindungan pekerja migran 
Indonesia dan keluarganya (Undang-Undang Nomor 39 Tahun 2004 tentang Penempatan dan Perlindungan Tenaga Kerja Indonesia).

Secara konseptual, harmonisasi hukum dimaknai sebagai upaya atau proses penyesuaian asas dan sistem hukum, agar terwujud kesederhanaan hukum, kepastian hukum dan keadilan. Harmonisasi hukum sebagai suatu proses dalam pembentukan peraturan perundangundangan, mengatasi hal-hal yang bertentangan dan kejanggalan di antara norma-norma hukum di dalam peraturan perundang-undangan, sehingga terbentuk peraturan perundang-undangan nasional yang harmonis, dalam arti selaras, seimbang, terintegrasi dan konsisten, serta taat asas.

Penjelasan di atas menjadi panduan umum dalam penyelarasan (harmonisasi) konvensi internasional perlindungan hak pekerja migran yang telah diratifikasi melalui UU No. 6 Tahun 2012 dengan UU No. 39 Tahun 2004. Harmonisasi kedua produk hukum ini merupakan upaya untuk menyesuaikan standar perlindungan pekerja migran Indonesia dengan standar hak asasi pekerja migran sebagaimana diatur dalam konvensi.

\section{Kedudukan Konvensi Internasional dalam Hukum Nasional} Indonesia

Kedudukan konvensi internasional dalam hukum nasional Indonesia merupakan hal yang patut diperhatikan dalam melakukan harmonisasi perjanjian internasional (UU No. 6 Tahun 2012) ke dalam hukum nasional Indonesia (UU No. 39 Tahun 2004). Dalam memahami 
topik ini perlu dikaji beberapa pendapat para ahli untuk menjadi pertimbangan, pendapat pertama dari Damos Dumoli Agusman, diplomat Indonesia dan pakar di bidang perjanjian internasional sebagai berikut: "Hukum, doktrin dan praktik Indonesia tentang status perjanjian internasional dalam hukum nasional $\mathrm{RI}$ belum berkembang dan sering menimbulkan persoalan praktis dalam tataran implementasi perjanjian internasional di dalam kerangka sistem hukum nasional. Ketidakjelasan ini merupakan bagian dari ketiadaan hukum maupun doktrin pada sistem hukum Indonesia tentang hubungan hukum internasional dan hukum nasional. Berbagai kebingungan mencuat dalam dunia praktisi untuk menjawab pertanyaan tentang status perjanjian internasional dalam sistem hukum Indonesia". ${ }^{3}$

Pendapat di atas menjelaskan posisi konvensi internasional dalam sistem hukum nasional Indonesia yang masih belum jelas, sehingga praktek dalam melakukan harmonisasi diantara keduanya seperti yang dilakukan dalam penelitian ini masih belum dilembagakan dengan baik. Konvensi internasional yang seharusnya ketika telah diratifikasi dapat langsung diimplementasikan dalam sistem hukum nasional beberapa negara, tetapi dalam kasus Indonesia masih perlu dilakukan "harmonisasi" dengan mengadopsi sebagian atau keseluruhan konvensi tersebut pada produk hukum terkait atau dibuatkan produk hukum tersendiri.

Dalam tataran teori hukum tata negara, menurut Damos Dumoli Agusman perjanjian internasional (traktat) sudah dikenal sebagai sumber

\footnotetext{
${ }^{3}$ Damos Dumoli Agusman, (2010), Hukum Perjanjian Internasional: Kajian Teori dan Praktik Indonesia, Bandung: Refika Aditama. h. 95.
} 
hukum dan kedudukannya adalah berdiri sendiri dan terpisah dari Undang-Undang. Namun menurut Bagir Manan dituangkannya perjanjian internasional ke dalam bentuk undang-undang pengesahan, terlepas dari arti kedudukan Undang-Undang ini, merupakan suatu "kontradiksi keilmuan". 4

Secara teoretis persoalan ini berakar pada ketidakjelasan tentang aliran/doktrin yang dianut oleh hukum Indonesia tentang hubungan hukum internasional dan hukum nasional. Pada negara-negara maju, aliran ini telah dicerminkan dalam constitutional provisions atau Undang-Undang nasional yang secara tegas memuat kaidah tentang status hukum internasional dalam hukum nasionalnya. Sistem hukum Indonesia sayangnya masih belum memberi perhatian pada permasalahan ini, sehingga jangankan suatu constitutional legal provisions, wacana publik ke arah pembentukan politik hukum tentang persoalan ini juga belum dimulai. ${ }^{5}$

Menurut Damos Dumoli Agusman secara teoretis terdapat beberapa pilihan politik hukum yaitu:

(a) aliran dualisme yang menempatkan hukum internasional sebagai sistem hukum yang terpisah dari hukum nasional. Dalam hal ini tidak terdapat hubungan hierarki antara kedua sistem hukum ini. Konsekuensi dari aliran ini adalah diperlukannya lembaga hukum "transformasi" untuk mengkonversikan hukum internasional ke dalam hukum

${ }^{4}$ Ibid.

${ }^{5}$ Ibid. 
nasional berdasarkan peraturan perundang-undangan yang berlaku untuk prosedur konversi ini. Pengikatan diri suatu negara ke suatu perjanjian (misalnya melalui ratifikasi) harus dilanjutkan proses transformasi melalui pembuatan legislasi nasional. Dengan dikonversikannya kaidah hukum internasional ini ke dalam hukum nasional, maka kaidah tersebut akan berubah karakter menjadi produk hukum nasional dan berlaku sebagai hukum nasional serta tunduk dan masuk pada tata urutan perundangan-undangan nasional. Karena sistem yang terpisah maka tidak memungkinkan adanya konflik di antara kedua hukum ini;

(b) Aliran monisme yang menempatkan hukum internasional dan hukum nasional sebagai bagian dari satu kesatuan sistem hukum. Hukum internasional berlaku dalam ruang lingkup hukum nasional tanpa harus melalui proses transformasi. Pengikatan diri suatu negara kepada suatu perjanjian (misalnya dengan ratifikasi) merupakan inkorporasi perjanjian tersebut ke dalam hukum nasional dan tidak dibutuhkan legislasi nasional yang sama untuk memberlakukannya dalam hukum nasional. Kalaupun ada legislasi nasional yang mengatur masalah yang sama maka legislasi yang dimaksud hanya merupakan implementasi dari kaidah hukum internasional dimaksud. Dalam hal ini, hukum internasional yang berlaku dalam sistem hukum nasional akan tetap pada karakternya sebagai hukum 
internasional. Mengingat merupakan kesatuan sistem maka terdapat kemungkinan adanya konflik antara hukum nasional dan hukum internasional. Untuk itu aliran ini kemudian terbagi menjadi dua yaitu yang mendahulukan hukum nasional (primat hukum nasional) dan yang mendahulukan hukum internasional (primat hukum internasional). ${ }^{6}$

Tabel 4.1. Perbandingan Monisme dan Dualisme

\begin{tabular}{|l|l|}
\hline \multicolumn{1}{|c|}{ Monisme } & \multicolumn{1}{c|}{ Dualisme } \\
\hline $\begin{array}{l}\text { - Hukum internasional dan hukum } \\
\text { nasional merupakan suatu kesatuan } \\
\text { sistem. }\end{array}$ & $\begin{array}{l}\text { - Hukum internasional dan hukum } \\
\text { nasional berlaku pada wilayah yang } \\
\text { berbeda }\end{array}$ \\
\hline $\begin{array}{l}\text { - Aparat hukum menerapkan norma } \\
\text { hukum internasional dalam } \\
\text { statusnya sebagai norma hukum } \\
\text { internasional. }\end{array}$ & $\begin{array}{l}\text { - Aparat hukum menerapkan hukum } \\
\text { internasional dalam statusnya } \\
\text { sebagai norma hukum nasional. }\end{array}$ \\
\hline $\begin{array}{l}\text { - Hukum internasional di inkorporasi } \\
\text { dengan hukum nasional. }\end{array}$ & $\begin{array}{l}\text {-Hukum internasional ditransformasi } \\
\text { ke dalam hukum nasional. }\end{array}$ \\
\hline $\begin{array}{l}\text { - Terbuka munculnya konflik antara } \\
\text { hukum internasional dengan hukum } \\
\text { nasional. Melahirkan primat hukum } \\
\text { internasional atau primat hukum } \\
\text { nasional. }\end{array}$ & - Tidak mungkin terjadi konflik \\
kama wilayahnya berbeda. \\
$\begin{array}{l}\text { Sumber: Damos Dumoli Agusman, (2010), Hukum Perjanjian Internasional: Kajian Teori dan } \\
\text { Praktik Indonesia, Bandung: Refika Aditama. hh. } 97-98 .\end{array}$
\end{tabular}

Sejalan dengan pendapat di atas, Sefriani, pakar hukum internasional dalam bukunya Peran Hukum Internasional dalam Hubungan Internasional Kontemporer menyatakan bahwa kedudukan perjanjian internasional dalam hukum nasional suatu negara pada umumnya dapat dilihat dari apakah suatu negara menganut doktrin monism dualisme atau kombinasi dari keduanya yang kemudian ditindaklanjuti oleh doktrin transformasi, delegasi, atau inkorporasi. Bagi penganut dualisme yang berpandangan antara hukum nasional $(\mathrm{HN})$ dan hukum internasional $(\mathrm{HI})$

\footnotetext{
${ }^{6}$ Ibid., h. 97.
} 
terpisah sama sekali maka untuk dapat diberlakukannya $\mathrm{HI}$ ke dalam $\mathrm{HN}$ harus melalui proses transformasi dulu. $\mathrm{HI}$ tersebut harus dijelmakan dulu ke dalam $\mathrm{HN}$ baik secara formal maupun substantif. Adapun bagi penganut monisme $\mathrm{HI}$ merupakan bagian dari $\mathrm{HN}$ otomatis teinkorporasikan ke dalam $\mathrm{HN}$ sehingga tidak memerlukan proses transformasi lagi. ${ }^{7}$

Mochtar Kusumaatmadja dan Etty R. Agoes dalam bukunya Pengantar Hukum Internasional juga membahas mengenai aliran dualisme dan monisme. Aliran dualisme bersumber pada teori bahwa daya ikat hukum internasional bersumber pada kemauan negara, hukum internasional dan hukum nasional merupakan dua sistem atau perangkat hukum yang terpisah satu dari yang lainnya. Alasan yang diajukan oleh penganut aliran dualisme bagi pandangan ini didasarkan pada alasan formal maupun alasan yang berdasarkan kenyataan. Di antara alasanalasan yang terpenting dikemukakan hal sebagai berikut:

(1) kedua perangkat hukum tersebut yakni hukum nasional dan hukum internasional mempunyai sumber yang berlainan, hukum nasional bersumber pada kemauan negara, sedangkan hukum internasional bersumber pada kemauan bersama masyarakat negara;

(2) kedua perangkat hukum itu berlainan subjek hukumnya. Subjek hukum dari hukum nasional ialah orang perorangan baik dalam apa yang dinamakan hukum perdata maupun hukum publik,

7 Sefriani, (2016), Peran Hukum Internasional dalam Hubungan Internasional Kontemporer, Jakarta: PT. RajaGrafindo Persada, hh. 117-118. 
sedangkan subjek hukum dari hukum internasional ialah negara;

(3) sebagai tata hukum, hukum nasional dan hukum internasional menampakkan pula perbedaan dalam strukturnya. Lembaga yang diperlukan untuk melaksanakan hukum dalam kenyataannya, seperti mahkamah dan organ eksekutif hanya ada dalam bentuk yang sempurna dalam lingkungan hukum nasional. Alasan lain yang dikemukakan sebagai argumentasi yang didasarkan atas kenyataan ialah bahwa daya laku atau keabsahan kaidah hukum nasional tidak terpengaruh oleh kenyataan bahwa kaidah hukum nasional itu bertentangan dengan hukum internasional. Dengan perkataan lain dalam kenyataan ketentuan hukum nasional tetap berlaku secara efektif sekalipun bertentangan dengan ketentuan hukum internasional. $^{8}$

Sedangkan, aliran monisme didasarkan atas pemikiran kesatuan dari seluruh hukum yang mengatur hidup manusia. Dalam rangka pemikiran ini hukum internasional dan hukum nasional merupakan dua bagian dari satu kesatuan yang lebih besar yaitu hukum yang mengatur kehidupan manusia. Pandangan yang melihat kesatuan antara hukum nasional dan hukum internasional dengan primat hukum nasional ini pada hakikatnya menganggap bahwa hukum internasional itu bersumber pada hukum nasional. Alasan utama anggapan ini ialah:

\footnotetext{
${ }^{8}$ Mochtar Kusumaatmadja dan Etty R. Agoes, (2015), Pengantar Hukum Internasional, Bandung: Pusat Studi Wawasan Nusantara, Hukum dan Pembangunan dan PT. Alumni. hh. 57-58.
} 
(1) bahwa tidak ada satu organisasi di atas negara-negara yang mengatur kehidupan negara-negara di dunia ini;

(2) dasar hukum internasional yang mengatur hubungan internasional terletak dalam wewenang negara untuk mengadakan perjanjian internasional, jadi wewenang konstitusional. Paham monisme dengan primat hukum nasional ini memiliki beberapa kelemahan. Kelemahan dasar ialah bahwa paham ini terlalu memandang hukum itu sebagai hukum yang tertulis semata-mata sehingga sebagai hukum internasional dianggap hanya hukum yang bersumberkan perjanjian internasional, suat hal sebagaimana diketahui tidak benar. Kelemahan kedua ialah pada hakikatnya pendirian paham kaum monisme dengan primat hukum nasional ini merupakan penyangkalan terhadap adanya hukum internasional yang mengikat negara. ${ }^{9}$

Soemaryo dalam Eddy Pratomo menyatakan terdapat beberapa teori yang dianut dalam hubungan antara hukum internasional dan hukum nasional yakni:

(a) Teori Monisme: Teori ini berpandangan bahwa kewajiban internasional dan aturan-aturan negara merupakan dua segi fenomena yang sama, yang keduanya berasal dari satu norma dasar dan berasal dari tatanan kesatuan konsepsi hukum. Penganut teori ini berpendapat bahwa ilmu pengetahuan hukum

\footnotetext{
${ }^{9}$ Ibid. hh. 61-62.
} 
itu merupakan satu bidang ilmu pengetahuan yang menyatu. Karena itu, hukum internasional benar-benar merupakan hukum dalam arti yang sebenarnya. Teori monisme ini dipelopori oleh Wright, Kelsen, Lauterpacht dan Duguit;

(b) Teori Dualisme: Teori ini menganggap bahwa aturan-aturan dalam sistem hukum internasional dan hukum nasional dibedakan satu sama lain dan tidak dapat berarti bahwa yang satu dapat mempengaruhi atau mengesampingkan lainnya. Hukum internasional dan hukum nasional keduanya berbeda secara esensial karena masing-masing sistem mengatur masalah-masalah yang berbeda. Penganut teori ini beranggapan bahwa hukum internasional dan hukum nasional adalah dua hukum yang berbeda karena hukum nasional berbeda dengan aturan internasional. Penganut teori ini adalah Strupp, Triepel, Hegel dan Anzilotti;

(c) Specific Adoption Theory. Teori ini berpandangan bahwa hukum internasional dapat diterapkan dalam bidang hukum nasional sesuatu negara hanya jika hukum nasional mengizinkannya atau mengesahkannya secara khusus seperti halnya dengan perjanjian-perjanjian internasional;

(d) Teori Transformasi. Teori ini berpandangan bahwa baik hukum internasional maupun hukum nasional merupakan dua sistem hukum yang berbeda, yang bekerja secara terpisah dan karena itu, sebelum sesuatu aturan atau prinsip internasional bisa 
berpengaruh terhadap yurisdiksi nasional, maka hal itu harus ditransformasikan secara jelas dan khusus ke dalam peraturan perundang-undangan nasional yaitu dengan menggunakan mekanisme konstitusional yang layak seperti proses ratifikasi atau akses oleh Parlemen (DPR);

(e) Delegation Theory. Teori ini berpendapat bahwa aturan hukum internasional dalam Undang-Undang Dasar suatu negara yang memperbolehkan untuk menetapkan bahwa perjanjianperjanjian internasional dapat diterapkan dalam bidang hukum nasional. Dengan demikian, tidak diperlukan lagi baik pengesahan secara khusus maupun transformasi terhadap aturan hukum internasional dalam setiap kasus. Aturan hukum internasional dapat diterapkan dalam bidang hukum nasional sesuai dengan prosedur dan sistem yang ada dalam setiap negara menurut Undang-Undang Dasarnya;

(f) Teori Inkorporasi. Teori ini menganggap bahwa hukum internasional secara otomatis merupakan bagian dari hukum nasional tanpa memerlukan prosedur ratifikasi oleh parlemen. Teori ini sebenarnya mengacu pada hukum kebiasaan internasional dan aturan-aturan yang berbeda yang diterapkan pada perjanjian-perjanjian internasional. ${ }^{10}$

Munculnya beberapa teori tersebut menunjukkan betapa pentingnya peran dan fungsi hukum internasional, termasuk perjanjian

\footnotetext{
${ }^{10}$ Eddy Pratomo, (2016), Hukum Perjanjian Internasional: Dinamika dan Tinjauan Kritis
} terhadap Politik Hukum Indonesia, Jakarta: PT. Elex Media Komputindo. hh. 488-490. 
internasional dalam pergaulan bangsa-bangsa. Terjadinya perbedaan (tarik ulur) dalam pengenalan beberapa teori oleh para ahli hukum internasional tersebut juga telah mengindikasikan adanya perdebatan yang panjang tentang hubungan dinamis dan interaktif antara hukum internasional dan hukum nasional yang pada gilirannya membutuhkan sikap tegas dari pemerintah masing-masing negara. ${ }^{11}$

Eddy Pratomo menggambarkan perbandingan konsep antara paham monisme (baik primat hukum nasional dan primat hukum internasional) dengan paham dualisme pada tabel berikut.

Tabel 4.2 Perbandingan Paham Monisme - Dualisme

\begin{tabular}{|c|c|c|c|}
\hline & $\begin{array}{l}\text { Monisme primat } \\
\text { hukum nasional }\end{array}$ & $\begin{array}{l}\text { Monisme primat } \\
\text { hukum internasional }\end{array}$ & he \\
\hline & $\begin{array}{l}\text { J. J. Moser, C. } \\
\text { Bergbohm, A. Zorn, } \\
\text { M. Wensel }\end{array}$ & $\begin{array}{l}\text { W. Kaufmann, Hans } \\
\text { Kelsen, A. Verdross, } \\
\text { G. Scelle }\end{array}$ & $\begin{array}{l}\text { H. Triepel, } \\
\text { Anzilotti }\end{array}$ \\
\hline & $\begin{array}{lr}\text { Hukum nasional } & \text { nada } \\
\text { lebih utama daripada } \\
\text { hukum internasional } \\
\text { karena hukum } \\
\text { internasional } \\
\text { bukanlah suatu } \\
\text { bentuk pedoman } \\
\text { perilaku individu. } \\
\text { Yang diutamakan } \\
\text { adalah kepentingan } \\
\text { negara terkait, } \\
\text { dimana hal ini } \\
\text { mengesampingkan } \\
\text { keberadaan hukum } \\
\text { internasional sebagai } \\
\text { suatu badan yang } \\
\text { mandiri dan terpisah. }\end{array}$ & 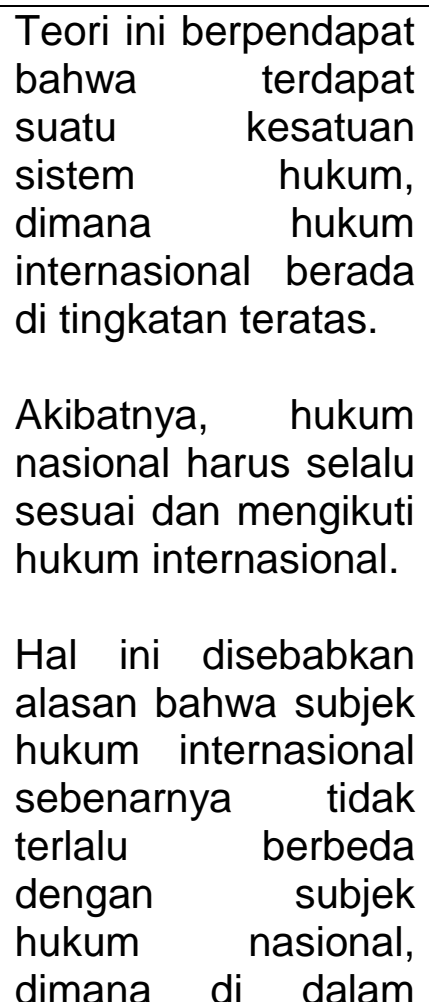 & $\begin{array}{l}\text { Hukum } \\
\text { internasional dan } \\
\text { hukum nasional } \\
\text { adalah dua sistem } \\
\text { hukum yang } \\
\text { berbeda dan } \\
\text { terpisah satu } \\
\text { sama lain. } \\
\text { Perbedaan isi } \\
\text { terdapat pada: } \\
1 . \quad \text { Subjek } \\
\text { hukumnya bagi } \\
\text { (individu nasional } \\
\text { hukum negara pada } \\
\text { dan nan bagi } \\
\text { umumnya bukum } \\
\text { hukumasional) } \\
\text { internasionber } \\
2 . \\
\text { hukumnva Sumber }\end{array}$ \\
\hline
\end{tabular}

${ }^{11}$ Ibid. hh. 490-491. 


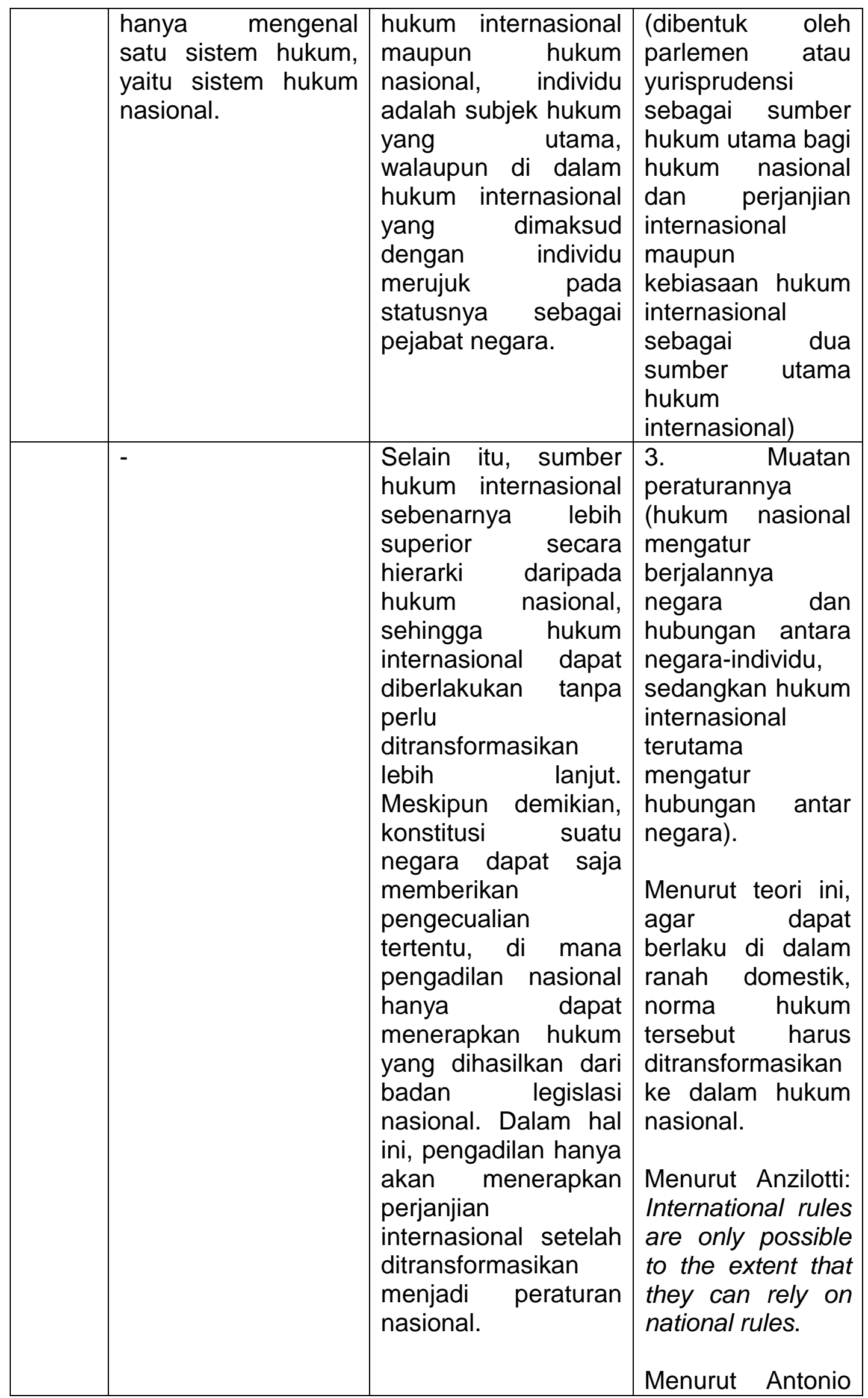




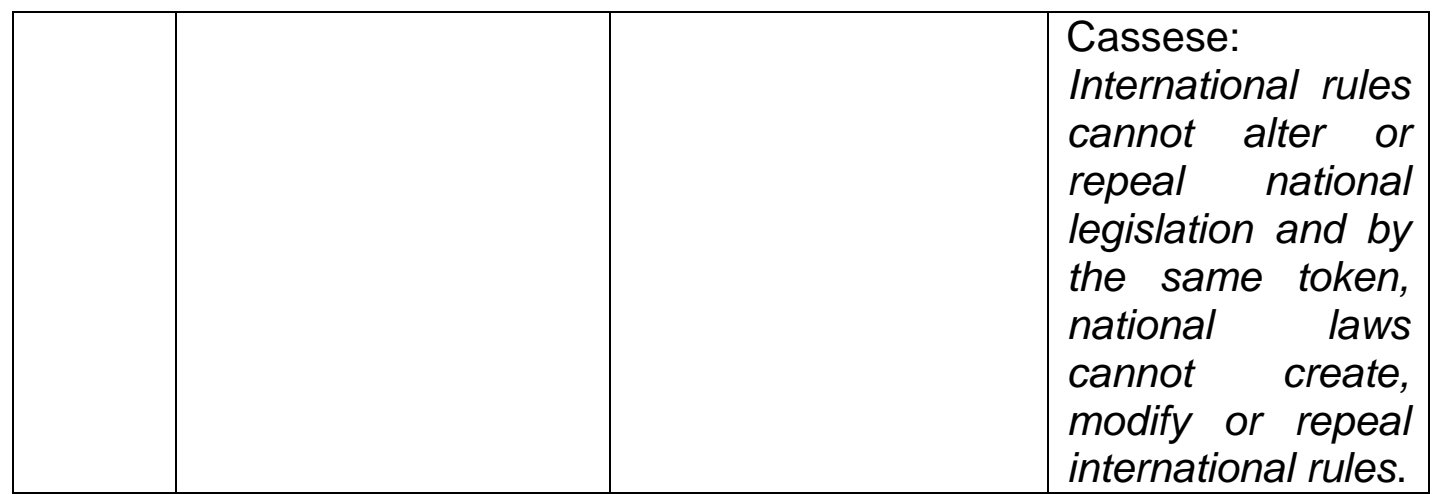

Sumber: Eddy Pratomo, (2016), Hukum Perjanjian Internasional: Dinamika dan Tinjauan Kritis terhadap Politik Hukum Indonesia, Jakarta: PT. Elex Media Komputindo. h 139.

Perbedaan paham seperti yang ditunjukkan dalam Tabel 4.2 di atas, masalah yang kemudian timbul adalah bagaimana dan sejauh mana norma serta ketentuan dalam sebuah perjanjian internasional dapat diterapkan di dalam hukum nasional masing-masing negara anggota? Hal ini tentu saja vital karena inti dari perjanjian internasional terletak dalam pelaksanaan ketentuan-ketentuan perjanjian internasional itu oleh setiap negara anggotanya. Tidak jelasnya paham yang dianut oleh sebuah negara dapat berakibat pada tidak jelasnya kepatuhan sebuah negara dalam melaksanakan kewajiban internasionalnya, yaitu dengan menerapkan norma dalam perjanjian internasional yang telah disepakatinya. Dalam situasi seperti ini, sebuah negara dapat kemudian berlindung di balik hukum nasionalnya sebagai alasan tidak diterapkannya norma perjanjian internasional, sehingga tujuan awal dibuatnya perjanjian internasional tersebut pun tidak akan tercapai. ${ }^{12}$

Selain itu, ketidakjelasan ini juga akan berdampak pada ketidakpastian hukum bagi warganegara negara anggota. Tanpa adanya kejelasan proses mengintegrasikan hukum internasional ke dalam hukum

\footnotetext{
12 Ibid. h. 140.
} 
nasional akan berakibat pada tidak jelasnya norma hukum yang berlaku. Pertanyaan yang kemudian muncul adalah norma hukum mana yang berlaku dan akan didahulukan? Bagaimana jika hukum nasional (undangundang dan produk hukum nasional lainnya) bertentangan dengan ketentuan dalam perjanjian internasional yang telah diratifikasi negara terkait? Apakah hakim dapat serta merta mengacu pada ketentuan dalam perjanjian internasional atau tidak ${ }^{13}$

Hal-hal seperti inilah yang menjadi alasan mengapa perlu adanya kejelasan atas proses atau paham yang dianut sebuah negara dalam mengintegrasikan hukum internasional (perjanjian internasional) ke dalam hukum nasionalnya. Terlepas dari pentingnya kejelasan ini, sangatlah sulit untuk menentukan paham yang lebih baik dari paham lainnya. Hal ini disebabkan proses dan paham yang dianut bergantung pula pada karakteristik masing-masing negara, seperti sistem hukum, sistem pemerintahan dan sejarah politik negara-negara tersebut. ${ }^{14}$

Menurut Damos Dumoli Agusman, negara-negara hukum modern seperti Amerika Serikat, Inggris dan negara-negara Eropa Barat, pengembangan doktrin tentang hubungan hukum ini telah digulirkan sejak awal abad ke-20-an melalui proses wacana publik yang cukup panjang termasuk pada proses legislasi maupun yurisprudensi yang akhirnya terkristalisasi dalam suatu pilihan politik hukum baik monisme, dualisme maupun kombinasi keduanya. Pada negara-negara tersebut, persoalan kedudukan hukum internasional baik hukum kebiasaan internasional

\footnotetext{
13 Ibid. hh. 140-141.

14 Ibid. h. 141.
} 
maupun perjanjian internasional dalam hukum nasional mereka telah tuntas dan pada umumnya dapat dipetakan sebagai penganut aliran monisme (Belanda, Italia, Perancis), dualisme (Amerika Serikat, Inggris, Australia) atau kombinasi keduanya (Jerman, monisme untuk hukum kebiasaan internasional dan dualisme untuk perjanjian internasional). ${ }^{15}$

Secara spesifik, praktik di Perancis sebagai negara penganut monisme, menunjukkan bahwa kewenangan membuat perjanjian internasional pada negara ini dipegang oleh lembaga eksekutif atas persetujuan ratifikasi oleh Senat, sebagai lembaga legislatifnya. Namun, untuk beberapa jenis perjanjian internasional seperti perjanjian menyangkut masalah perdamaian, perdagangan, teritorialitas atau perjanjian internasional lain yang dapat mengubah dan membuat ketentuan hukum baru di Perancis, persetujuan perlu didapatkan selain dari Senat juga dari National Assembly. Dengan diberikannya ratifikasi, kepada perjanjian internasional ini harus dipublikasikan dalam lembaran negara (Journal Officiel), yang kemudian akan langsung berlaku mengikat kepada setiap warga negara dan pengadilan dapat langsung mengacu pada perjanjian internasional terkait. ${ }^{16}$

Praktik serupa ditunjukkan oleh Belanda, perjanjian internasional memiliki kedudukan lebih tinggi daripada hukum nasional dalam hierarki tata urutan peraturan perundang-undangan yang berlaku di Belanda. Begitu pula dengan praktik di Polandia, Rusia, Switzerland dan Jerman, perjanjian internasional langsung menjadi bagian hukum nasional negara

\footnotetext{
${ }^{15}$ Damos Dumoli Agusman. op. cit., h. 98.

${ }^{16}$ Eddy Pratomo, op. cit., h. 136.
} 
tersebut pada saat ratifikasi dilakukan. Selanjutnya, perjanjian internasional ini akan dapat dirujuk dan digunakan di dalam pengadilan di negara tersebut. ${ }^{17}$

Berbeda dengan praktik-praktik di atas adalah praktik di Inggris yang memang menganut paham dualisme, perjanjian internasional tidak akan serta merta berlaku walaupun telah diratifikasi. Dalam hal ini, perjanjian internasional tidak mempunyai efek apapun di dalam hukum nasional Inggris, walaupun tetap mengikat negara Inggris dalam hubungannya di dalam ranah hukum internasional. Perjanjian internasional ini baru akan memiliki akibat hukum apabila telah ada dan berlaku legislasi nasional yang mengatur ketentuan-ketentuan dalam perjanjian internasional tersebut. Sebagai konsekuensinya, perjanjian internasional tidak dapat menjadi rujukan dalam pengadilan nasional Inggris, melainkan legislasi nasional terkaitlah yang dapat dan akan dirujuk dalam pengadilan-pengadilan Inggris. Dalam hal ini, tampak bahwa produk hukum nasional-lah yang memiliki akibat hukum di dalam hukum nasional Inggris.

Mochtar Kusumaatmadja tentang kedudukan perjanjian internasional di dalam hukum nasional Indonesia yakni:

“... Kita tidak menganut teori transformasi apalagi sistem Amerika Serikat. Kita lebih condong pada sistem negara-negara continental Eropa... yakni langsung menganggap diri kita terikat pada kewajiban melaksanakan dan mentaati ketentuan-ketentuan perjanjian dan konvensi yang telah disahkan tanpa perlu mengadakan lagi perundang-undangan pelaksanaan (implementing legislation)."18

\footnotetext{
17 lbid. h. 137.

${ }^{18}$ Mochtar Kusumaatmadja dan Etty R. Agoes, op. cit., h. 92.
} 
Mochtar Kusumaatmadja dalam bukunya Pengantar Hukum Internasional juga menyebutkan:

“... Tetapi dalam beberapa hal pengundangan dalam undangundang nasional adalah mutlak diperlukan. Hal-hal tertentu yang dimaksud adalah apabila perjanjian internasional yang telah disahkan memuat ketentuan diperlukannya perubahan dalam undang-undang nasional yang langsung menyangkut hak warga negara sebagai orang per orang". ${ }^{19}$

Menanggapi pendapat Mochtar Kusumaatmadja, Eddy Pratomo berpendapat bahwa prinsip yang terkandung dalam pendapat Mochtar menganut prinsip yang mengarah kepada teori inkorporasi (terhadap perjanjian internasional bahwa negara sebagai subjek hukum internasional terikat secara eksternal) dan teori transformasi (terhadap perjanjian internasional, setiap warga negara terikat secara internal). ${ }^{20}$

Berkaitan dengan pendapat di atas, Eddy Pratomo menyatakan bahwa pendapat Mieke Komar Kantaatmadja juga memiliki pandangan yang hampir sama yakni perlunya mentransformasi Konvensi ke dalam perundang-undangan, sebagai berikut:

"Apabila materi konvensi yang akan diberlakukan berbeda dengan ketentuan perundang-undangan yang ada (dan belum berubah), karena berdasarkan atas konvensi internasional yang lama sedangkan RI telah terikat oleh konvensi baru..."21

Sejalan dengan pandangan di atas, Hikmahanto Juwana, Guru

Besar Hukum Internasional Universitas Indonesia berpendapat:

“... Setiap perjanjian internasional yang telah diikuti oleh Indonesia yang memuat kewajiban untuk dilaksanakan di tingkat nasional (baik yang diratifikasi atau tidak) perlu untuk diterjemahkan atau ditransformasikan ke dalam hukum nasional. Sehingga perjanjian internasional yang telah diikuti tidak berhenti sampai disitu.

\footnotetext{
19 lbid. h. 94.

${ }^{20}$ Eddy Pratomo, op. cit., h. 418.

21 lbid. h. 418.
} 
Pemerintah Indonesia mempunyai kewajiban untuk menyisir berbagai peraturan perundang-undangan Indonesia dan menentukan mana yang bertentangan dan mana yang belum diatur dan perlu dibuat aturannya"22

Eddy Pratomo mencontohkan keikutsertaan Indonesia dalam

United Nations Convention Against Corruption (UNCAC), sebagai berikut:

"Sebagai contoh, keikutsertaan Indonesia dalam UNCAC yang saat ini sedang dilakukan penerjemahan ke dalam hukum nasional. UU No. 31 Tahun 1999 tentang Pemberantasan Tindak Pidana Korupsi (UU PTPK) yang berlaku akan diamandemen dan disesuaikan dengan UNCAC. Bila ada kasus yang menggunakan langsung UNCAC tentu itu tidak bisa dilakukan karena tidak mungkin terdakwa dijerat dengan perjanjian internasional. Bila ada ketentuan yang bertentangan antara UNCAC dengan UU PTPK, UU PTPK yang berlaku karena UNCAC belum merupakan hukum positif $^{23}$

Jika memperhatikan pandangan beberapa ahli hukum internasional tersebut di atas, maka dapat ditarik kesimpulan sementara bahwa teori kombinasi yakni teori inkorporasi dan teori transformasi tentang kedudukan atau status perjanian internasional dalam hukum nasional Indonesia merupakan praktik yang saat ini sedang berlangsung dalam sistem ketatanegaraan Indonesia. ${ }^{24}$

Walau demikian, Eddy Pratomo menambahkan negara-negara yang tidak secara jelas menganut salah satu paham (monisme maupun dualisme) dalam praktik ketatanegarannya, seperti Indonesia. Konsekuensinya, status dan implementasi hukum internasional (termasuk penerapan ketentuan dari perjanjian-perjanjian internasional) menjadi tidak jelas. ${ }^{25}$ Sefriani menekankan walaupun praktik Indonesia tidaklah

${ }^{22}$ Ibid h. 419.

${ }^{23}$ Ibid. hh. 419-420.

${ }^{24}$ Ibid. h. 420.

${ }^{25}$ Ibid. hh. 137-138. 
jelas menganut doktrin yang mana, dan beragamnya pendapat pakar hukum mengenai hal ini. Sebagian pakar menyatakan tanpa aturan pelaksana dalam $\mathrm{HN}$ maka $\mathrm{HI}$ belum bisa diberlakukan. ${ }^{26}$

Praktik Indonesia terkait kedudukan hukum internasional (perjanjian/konvensi internasional) dalam hukum nasional, jika mengacu pada Undang-Undang No. 24 Tahun 2000 tentang Perjanjian Internasional memang tidak secara tegas menjelaskan kedudukan perjanjian internasional dalam sistem perundang-undangan, namun hanya menyatakan bahwa perjanjian internasional disahkan dengan UndangUndang/Peraturan Presiden tanpa lebih lanjut menjelaskan apa arti dan konsekuensinya bagi perundang-undangan Indonesia. Apakah dengan pengesahan melalui Undang-Undang maka perjanjian internasional menjadi setara dengan Undang-Undang merupakan pertanyaan yang masih belum terjawab sampai saat ini. ${ }^{27}$

Jika dikaji lebih lanjut dalam UU No. 10 Tahun 2004 yang telah mengalami perubahan dalam UU No. 12 Tahun 2011 tentang Pembentukan Peraturan Perundang-Undangan, perjanjian internasional masih belum dimasukkan dalam susunan jenis peraturan perundangundangan. Hal ini dapat dilihat pada Pasal 7 tentang hierarki perundangundangan sebagai berikut:

\footnotetext{
${ }^{26}$ Sefriani, loc. cit.

27 Damos Dumoli Agusman, op. cit., h. 96.
} 
Tabel 4.3 Perbandingan Hierarki Perundang-Undangan

\begin{tabular}{|l|l|}
\hline \multicolumn{1}{|c|}{ UU No. 10 Tahun 2004 } & \multicolumn{1}{c|}{ UU No. 12 Tahun 2011 } \\
\hline $\begin{array}{l}\text { a. Undang-Undang Dasar Negara } \\
\text { Republik Indonesia Tahun 1945; }\end{array}$ & $\begin{array}{l}\text { a. Undang-Undang Dasar Negara } \\
\text { Republik Indonesia Tahun 1945; }\end{array}$ \\
\hline \multicolumn{1}{|c|}{ - } & $\begin{array}{l}\text { b. Ketetapan Majelis Permusyawaratan } \\
\text { Rakyat; }\end{array}$ \\
\hline $\begin{array}{l}\text { b. Undang-Undang/Peraturan } \\
\text { Pemerintah Pengganti Undang- } \\
\text { Undang; }\end{array}$ & $\begin{array}{l}\text { c. Undang-Undang/Peraturan } \\
\text { Pemerintah Pengganti Undang- } \\
\text { Undang; }\end{array}$ \\
\hline c. Peraturan Pemerintah; & d. Peraturan Pemerintah; \\
\hline d. Peraturan Presiden; & e. Peraturan Presiden; \\
\hline e. Peraturan Daerah. & f. Peraturan Daerah Provinsi; dan \\
\cline { 2 - 2 } & g. Peraturan Daerah Kabupaten/Kota. \\
\hline
\end{tabular}

Berdasarkan Tabel 4.3 terlihat bahwa hierarki perundang-undangan dalam UU No. 10 Tahun 2004 yang kemudian di revisi pada UU No. 12 Tahun 2011 hanya memperlihatkan dikembalikannya Ketetapan Majelis Permusyawaratan Rakyat (Tap MPR) ke dalam hierarki dan pembagian lebih rinci peraturan daerah yakni peraturan daerah Provinsi dan peraturan daerah Kabupaten/Kota. Kenyataan ini semakin membuktikan bahwa masih tidak jelasnya doktrin tentang kedudukan hukum dari perjanjian internasional dalam hukum Indonesia.

Dalam tataran praktis di kalangan pemerintah dan opini publik Indonesia berkembang berbagai alur pikiran yang dapat dipetakan sebagai berikut: (1) alur pikiran yang menempatkan perjanjian internasional yang telah disahkan (diratifikasi) sebagai bagian dari hukum nasional; dan (2) alur pikiran yang mengharuskan adanya legislasi nasional tersendiri untuk mengimplementasikan suatu perjanjian internasional yang telah disahkan. ${ }^{28}$

${ }^{28}$ Ibid. h. 96. 
Penjelasan-penjelasan di atas jika direfleksikan terhadap penelitian ini, maka memberikan gambaran bahwa proses harmonisasi konvensi internasional perlindungan hak pekerja migran ke dalam perundangundangan, dalam hal ini UU No. 39 Tahun 2004 tentang penempatan dan perlindungan Tenaga Kerja Indonesia di luar negeri (PPTKILN) mutlak diperlukan.

Adapun mekanisme yang ditempuh perlu mempertimbangkan kedudukan konvensi internasional dalam hukum nasional Indonesia. Jika merujuk pada teori-teori yang telah dikemukakan yakni monisme dan dualisme oleh Damos Dumoli Agusman, Sefriani, Mochtar Kusumaatmadja dan Etty R. Agoes. Sedangkan, Eddy Pratomo menambahkan specific adoption theory, teori transformasi, delegation theory dan teori inkorporasi. Maka, Indonesia masih mengkombinasikan aliran dan teori tersebut. Dalam konteks penelitian ini, maka teori transformasi merupakan penjelasan dari proses harmonisasi konvensi internasional perlindungan hak pekerja migran dengan UU No. 39 Tahun 2004.

Bapak Yuli dari Direktorat Penempatan dan Perlindungan Tenaga Kerja Luar Negeri, Dirjen Binapenta dan PKK, Kementerian Ketenagakerjaan Republik Indonesia dalam wawancaranya dengan peneliti mengenai harmonisasi konvensi internasional perlindungan hak pekerja migran dengan UU No. 39 Tahun 2004 menyatakan bahwa:

"Undang-Undang yang diharmonisasi menyesuaikan dengan isi konvensi. Dimana konvensi sebagai dasar regulasi nasonal. 
Adapun konvensi tersebut harus merupakan UU hasil pengesahan yang diharmonisasi dengan UU No. 39 Tahun 2004". ${ }^{29}$

Pendapat di atas menjelaskan bahwa konvensi internasional, dalam penelitian ini yakni konvensi internasional perlindungan hak pekerja migran baru dapat dijadikan acuan setelah konvensi tersebut diratifikasi melalui pengesahan Undang-Undang sebagaimana dipersyaratkan oleh UU No. 24 Tahun 2000 tentang Perjanjian Internasional. Konvensi dan UU pengesahan konvensi tersebut tidak terdapat perbedaan, hanya menerjemahkan konvensi ke dalam bahasa Indonesia dan memberikan penjelasan apabila ada poin-poin yang tidak disepakati dari proses pengesahannya. Setelah itu, konvensi itu baru dapat diharmonisasi dengan UU terkait dalam hukum nasional Indonesia, dalam penelitian ini yakni UU No. 39 Tahun 2004 tentang Penempatan dan Perlindungan TKI di Luar Negeri

Achmad Zulfikar, pegiat Pekerja Migran Indonesia dalam risetnya mengenai Alasan Pemerintah Indonesia Meratifikasi Konvensi Internasional Perlindungan Hak Pekerja Migran Tahun 2012 memberikan penguatan terhadap konsekuensi atas ratifikasi konvensi perlindungan hak pekerja migran, sebagai berikut:

"Pemerintah Indonesia dalam hal ini telah mengikatkan diri pada perjanjian internasional (Konvensi Internasional Perlindungan Hak Pekerja Migran). Maka dari itu pemerintah kedepannya harus siap menerima konsekuensi atas keputusan yang telah diambil berdasarkan asas hukum lex loci delicti. Asas ini menerangkan bahwa hukum yang dikenakan terhadap orang asing yang berada di luar batas yurisdiksi negaranya akan mengacu pada aturan yang

\footnotetext{
${ }^{29}$ Hasil Wawancara dengan Bapak Yuli, Direktorat PPTKLN, Dirjen Binapenta dan PKK, Kementerian Ketenagakerjaan RI, 30 Januari 2017 di Kantor Kementerian Ketenagakerjaan RI, Jakarta.
} 
berlaku di negara tempat terjadinya peristiwa (the law of the place in which a delict is committed)".

Pendapat di atas jika dikaitkan dengan pendapat dari pakar di bidang perjanjian internasional, maka dapat dimaknai bahwa Konvensi Internasional Perlindungan Hak Pekerja Migran secara tujuan memiliki konsekuensi langsung terhadap Tenaga Kerja Asing (TKA) di wilayah Indonesia, namun demikian pemerintah Indonesia memandang bahwa manfaat bagi Tenaga Kerja Indonesia (TKI) di luar negeri juga dapat dioptimalkan.

Beberapa penelitian mengenai harmonisasi hukum maupun konvensi internasional perlindungan hak pekerja migran dilakukan oleh peneliti berikut. Pertama, Akbar Kurnia Putra meneliti tentang Harmonisasi konvensi cyber crime dalam hukum nasional. Penelitian ini menyimpulkan bahwa pengaturan cyber crime dalam Undang-Undang Informasi dan Transaksi Elektronik (UU ITE) memperlihatkan bahwa semua perbuatan yang direkomendasikan dalam European Convention on Cyber Crime (ECCC) telah diatur dalam UU ITE. Perbedaannya hanya pada tata letak atau urutan pengaturan berbagai perbuatan tersebut. Jika Konvensi ECCC memulai dengan perbuatan yang dikategorikan sebagai cyber crime dalam arti sempit (murni), maka pengaturan dalam UU ITE tidak mengikuti pola tersebut. ${ }^{30}$ Kajian dalam jurnal ini belum secara jelas menggambarkan apakah Konvensi ECCC sudah diratifikasi oleh pemerintah Indonesia atau belum, namun demikian dari pembahasannya

\footnotetext{
30 Akbar Kurnia Putra, (2014), Harmonisasi Konvensi Cyber Crime dalam Hukum Nasional, Jurnal Ilmu Hukum Vol. 5 No. 2 Tahun 2014. hh. 95-109. (http://onlinejournal.unja.ac.id/index.php/jih/article/view/1953)
} 
terlihat bahwa semua perbuatan yang direkomendasikan dalam Konvensi ECCC telah diatur dalam UU ITE.

Kedua, penelitian oleh Mosgan Situmorang mengenai harmonisasi hukum nasional di bidang korupsi dengan United Nations Convention Against Corruption. Penelitian ini menyimpulkan bahwa walaupun sudah 8 tahun (2006-2014) Indonesia meratifikasi konvensi PBB anti korupsi tahun 2003 (United Nations Convention Against Corruption/UNCAC) akan tetapi masih banyak ketentuan-ketentuan hukum nasional di bidang korupsi yang belum diselaraskan dengan konvensi tersebut. Oleh karena itu perlu membuat aturan-aturan untuk menselaraskan Konvensi UNCAC dengan peraturan pemberantasan korupsi dalam hukum nasional Indonesia dalam UU No. 39 Tahun 1999 jo UU No. 20 Tahun 2001 maupun dalam Kitab Undang-Undang Hukum Pidana (KUHP). ${ }^{31}$ Kajian dalam jurnal ini menunjukkan bidang kajian yang sama dengan penelitian ini yakni melakukan harmonisasi antara konvensi yang telah diratifikasi oleh pemerintah Indonesia dengan hukum nasional Indonesia.

Ketiga, Ratification of UN Convention on Migrant Workers (1990): The Case of Indonesia and The Philippines merupakan penelitian yang dipublikasikan dalam jurnal oleh Natasha K. Ardiani. Penelitian ini menyimpulkan bahwa konvensi hak pekerja migrant sangat penting sebagai basis hukum untuk setiap negara dalam memberikan perlindungan terhadap pekerjanya di luar negeri. Namun permasalahan

\footnotetext{
${ }_{31}$ Mosgan Situmorang, (2014), Harmonisasi Hukum Nasional di Bidang Korupsi dengan United Nations Convention Against Corruption, Jurnal RechtsVinding: Media Pembinaan Hukum Nasional Vol. 3 No. 3 Desember 2014, hh. 329-346. (http://rechtsvinding.bphn.go.id/view/?id=179\&isi=artikel)
} 
yang dihadapi yakni hanya sedikit negara yang memiliki itikad untuk meratifikasi Konvensi ini. Apalagi negara pengirim tenaga kerja seperti Indonesia belum meratifikasi Konvensi ini ketika masih banyak kesalahan perlakuan dan perlakuan tidak manusiawi masih terjadi. Sementara negara tetangga seperti Filipina telah memiliki struktur hukum yang komprehensif dalam memberikan perlindungan terhadap pekerja migrannya. Indonesia butuh meratifikasi Konvensi ini jika melihat kontribusi remitansi yang diberikan secara domestik. Pemerintah harus sadar bahwa keselamatan pekerja migran merupakan yang utama dan pemerintah dapat mengirim lebih banyak lagi pekerja migran secara aman dengan perlindungan hukum yang memadai. ${ }^{32}$ Kajian ini dilakukan sebelum pemerintah Indonesia meratifikasi konvensi internasional perlindungan hak pekerja migran. Kajian ini merupakan rujukan untuk melihat dinamika yang terjadi sebelum konvensi ini diratifikasi oleh Indonesia dan dapat dibandingkan dengan dinamika setelah konvensi ini diratifikasi.

Keempat, penelitian mengenai hukum nasional Indonesia pasca ratifikasi Konvensi Internasional Pekerja Migran dikaji Achmad Zulfikar dalam artikel jurnal berjudul "Indonesian Workers Protection Abroad: Indonesian Law Post-Ratification of International Convention on Migrant Workers". Hasil penelitian ini menyimpulkan bahwa terdapat hubungan positif antara ratifikasi Konvensi Internasional Perlindungan Hak Pekerja

\footnotetext{
32 Natasha K. Ardiani, (2009), Ratification of UN Convention on Migrant Workers (1990): The Case of Indonesia and The Philippines, Indonesian Journal of Social Sciences Vol. 1 No. 3 2009. (http://journal.unair.ac.id/ratification-of-un-convention-on-migrant-workers(1990)-the-case-of-indonesia-and-the-philippines-article-3100-media-35-category-8.html).
} 
Migran terhadap hukum nasional Indonesia hal ini dibuktikan dengan direncanakannya revisi UU No. 39 Tahun 2004 tidak lama setelah ratifikasi Konvensi dilakukan sehingga menghasilkan Rancangan UndangUndangan Perlindungan Pekerja Indonesia di Luar Negeri (RUU PPILN). Beberapa bagian dari UU No. 39 Tahun 2004 dan RUU PPILN yang merupakan hasil ratifikasi diselaraskan dengan Konvensi. Namun demikian, tidak semua standar perlindungan hak pekerja migrant dalam konvensi yang diakomodasi dalam RUU PPILN. ${ }^{33}$ Kajian dalam jurnal ini merupakan kajian pendahuluan yang dilakukan oleh peneliti. Dalam kajian ini peneliti masih terbatas dalam mengkaji implikasi atas ratifikasi konvensi internasional perlindungan hak pekerja migran dalam hukum nasional Indonesia, namun belum melakukan kajian spesifik terkait harmonisasi konvensi internasional perlindungan hak pekerja migran dengan UU No. 39 Tahun 2004.

Kelima, Rasionalitas Ekonomi Politik dalam Ratifikasi Konvensi Internasional Perlindungan Hak Pekerja Migran Tahun 2012 merupakan penelitian yang dipublikasikan dalam jurnal oleh Achmad Zulfikar. Hasil penelitian ini menyimpulkan bahwa pemerintah Indonesia meratifikasi konvensi internasional perlindungan hak pekerja migran dengan menggunakan rasionalitas ekonomi politik. Rasionalitas ekonomi dimaknai bahwa pemerintah Indonesia mendapatkan keuntungan ekonomi atas diratifikasinya konvensi internasional perlindungan hak pekerja migran

\footnotetext{
${ }^{33}$ Achmad Zulfikar, (2014), Indonesian Migrant Workers Protection Abroad: Indonesian Law Post-Ratification of International Convention on Migrant Workers, Juris Gentium Law Review Vol. 2 No. 1 September 2014, hh. 30-41. (http://cimc.ugm.ac.id/journal/index.php/juris-gentium/article/viewFile/51/45)
} 
yakni pemerintah memberikan kepastian hukum bagi pekerja migran asing di Indonesia sebagai bentuk menjaga investasi asing di Indonesia melalui perlindungan tenaga kerja asing (TKA) yang merupakan penggerak investasi dalam rangka menjaga pertumbuhan ekonomi Indonesia. Rasionalitas politik dalam hal ini ikut menyertai alasan utama (ekonomi) yang bersifat implisit (tidak langsung/tersirat). Alasan politik lebih bersifat eksplisit (langsung) yang disampaikan dalam pernyataan-pernyataan politis pemerintah pada pembahasan ratifikasi konvensi ini. Rasionalitas ini dimaknai bahwa pemerintah Indonesia mendapatkan keuntungan politik atas diratifikasinya konvensi perlindungan hak pekerja migran yakni meningkatkan posisi tawar (bargaining position) Indonesia terhadap negara-negara tujuan tenaga kerja Indonesia (TKI) dalam rangka perlindungan TKI di luar negeri. ${ }^{34}$ Kelima penelitian ini merupakan rujukan untuk mendalami fokus penelitian secara komprehensif.

Berdasarkan penjelasan di atas maka dapat dipahami bahwa konvensi internasional perlindungan hak pekerja migran yang telah diratifikasi melalui UU No. 6 Tahun 2012 memerlukan proses transformasi, walaupun diantara pakar dan ahli hukum internasional masih terdapat perdebatan. Proses transformasi ini dibutuhkan untuk mengadopsi substansi konvensi ke dalam UU PPTKILN, dikarenakan konvensi ini sesungguhnya memiliki konsekuensi langsung kepada TKA bukan terhadap PMI/TKI.

${ }^{34}$ Achmad Zulfikar, (2015), Rasionalitas Ekonomi Politik dalam Ratifikasi Konvensi Internasional Perlindungan Hak Pekerja Migran Tahun 2012, The Politics: Jurnal Magister IImu Politik Universitas Hasanuddin Vol. 1 No. 1 Januari 2015, hh. 37-49. (http://journal.unhas.ac.id/index.php/politics/article/view/128) 


\section{Evaluasi Undang-Undang Nomor 39 Tahun 2004 dan Kajian terhadap Peraturan Perundang-Undangan Terkait}

Undang-Undang Nomor 39 Tahun 2004 tentang Penempatan dan Perlindungan Tenaga Kerja Indonesia di Luar Negeri (PPTKILN) merupakan Undang-Undang yang ingin diharmonisasi dengan Konvensi Internasional Perlindungan Hak Pekerja Migran (UU No. 6 Tahun 2012), sebelum dilakukan harmonisasi terlebih dahulu Undang-Undang ini perlu di evaluasi pelaksanaannya. Secara garis besar masalah yang diidentifikasi dari hasil Rapat Dengar Pendapat antara Pakar dengan Komisi IX DPR RI dikutip dari Naskah Akademik RUU PPILN, sebagai berikut:

a. Sesuai dengan penamaan undang-undangnya, maka UU No. 39 Tahun 2004 lebih banyak mengatur penempatan daripada mengatur tentang perlindungan. Adapun jumlah pasal yang mengatur perlindungan hanya 8 pasal (7\%) dari 109 pasal, sedangkan pasal yang mengatur penempatan ada 66 pasal (38\%) dari 109 pasal, jadi konsentrasi dari UU No. 39 Tahun 2004 adalah pengaturan penempatan bukan perlindungan. Penataan pasal-pasal yang kurang dalam hal perlindungan dan berlebihan yang mengatur dalam masalah penempatan menyebabkan banyak kalangan yang berpendapat bahwa paradigma peraturan tersebut adalah 'komoditisasi TKl'.

b. UU No. 39 Tahun 2004 dibuat hampir bersamaan dengan perubahan UU No. 22 Tahun 1999 tentang Pemerintahan Daerah menjadi UU No. 32 Tahun 2004, tetapi tidak ada harmonisasi antara keduanya, 
terutama pada pasal-pasal yang mengatur tentang kewenangan daerah.

c. Di dalam UU No. 39 Tahun 2004 juga tidak ada konsistensi pasalpasalnya terutama tentang (a) kewajiban pemerintah untuk menjamin terpenuhinya hak-hak TKI yang berangkat melalui PPTKIS maupun TKI mandiri, tetapi di bagian perlindungan sebagian besar kewajibannya dilimpahkan kepada PPTKIS yakni melindungi TKI sesuai dengan perjanjian penempatannya; (b) pada Bab IV tentang Pelaksanaan Penempatan TKI di Luar Negeri, pemerintah juga merupakan pelaksana penempatan, tidak ada diatur lebih lanjut kemudian kewajiban untuk melindunginya; (c) tidak diatur juga tentang bagaimana bila pemerintah tidak melaksanakan perlindungan, tetapi yang diwajibkan (sanksi) bila pemerintah yang merupakan pihak yang menempatkan.

d. Terdapat dua lembaga yang punya kewenangan untuk melaksanakan perlindungan dan penempatan, yakni Departemen Tenaga Kerja dan Transmigrasi RI (sekarang Kementerian Ketenagakerjaan RI) dan Badan Nasional Penempatan dan Perlindungan TKI, dan sudah menjadi rahasia umum bahwa keduanya tidak melaksanakan koordinasi melainkan berseteru yang menjadikan salah satu sebab tidak produktifnya pelaksanaan perlindungan. Hal ini penyebab utamanya adalah pengaturan antara keduanya tidak jelas saling tumpang tindih dan saling meniadakan. 
e. Banyaknya amanat pasal untuk diatur lebih lanjut, tetapi tidak satupun yang mengamanatkan pengaturan lebih lanjut kepada peraturan daerah; pada hal pemerintah daerah juga dilimpahi untuk menanggulangi perlindungan. ${ }^{35}$

Dalam hal materi muatan dan ketentuan yang termuat dalam UU Nomor 39 Tahun 2004, pasal-pasal dan/atau ayat-ayat terkait 'perlindungan' hanya memberikan penjelasan secara umum sehingga pada tingkat praktiknya para pelaksana mendapati pasal-pasal dan ayatayat ini sangat sulit dilaksanakan. UU ini hanya menyatakan bahwa perlindungan dilaksanakan mulai dari pra-penempatan, masa penempatan sampai dengan purna-penempatan' (pasal 77 ayat 2). Bagaimana perlindungan itu dijalankan lebih lanjut tidak dijabarkan. Dari kedua sisi kedudukan dan isinya, bab ini sesungguhnya 'terisolasi' di dalam UU ini sendiri. Karenanya, menengarai makna isolasi dari bab VI tentang perlindungan ini, sulit dibantah bahwa bab ini tak lain berupa suatu preforma dari kewajiban menerapkan prinsip perlindungan, namun konsep perlindungan itu sendiri tidak atau belum diuraikan secara menyeluruh dalam seluruh kaitannya dengan bab-bab lain yang membentuk undangundang ini. ${ }^{36}$

Penjelasan di atas mengidentifikasi masalah pekerja migran Indonesia (TKI) antara lain: pasal yang diatur dalam UU No. 39 Tahun

${ }^{35}$ Umu Hilmy, Urgensi Perubahan UU Nomor: 39 Tahun 2004 tentang Penempatan dan Perlindungan Tenaga Kerja Indonesia di Luar Negeri, RDP antara Pakar dengan Panja Pekerja Indonesia Komisi IX tanggal 16 Desember 2010. dalam Naskah Akademik Rancangan Undang-Undang Perlindungan Pekerja Indonesia di Luar Negeri (RUU PPILN), $27 \quad$ Mei 2015.2 Diunduh dari http://wikidpr.org/uploads/ruu/56a7b0390d00db504b000027/naskah-akademik-ruuperlindungan-tenaga-kerja-di-luar-negeri-27-mei-2015.pdf, tanggal 3 Juni 2017. ${ }^{36} \mathrm{lbid}$. 
2004 masih berorientasi pada pengaturan penempatan dibandingkan perlindungan dan konsep perlindungan TKI yang belum diuraikan secara jelas dan lugas, selanjutnya peran pemerintah daerah yang belum optimal dan tidak diamanatkannya peraturan turunan untuk memberikan perlindungan TKI oleh pemerintah daerah, kemudian kewajiban perlindungan PMI/TKI lebih dibebankan kepada PPTKIS (perusahaan penempatan/swasta), lalu pengaturan kelembagaan antara Kementerian yang membidangi Ketenagakerjaan dan Badan yang dibentuk khusus untuk mengurus penempatan dan perlindungan TKI masih belum sinergis.

Evaluasi dilanjutkan dengan mengidentifikasi muatan pasal dan ayat dalam UU Nomor 39 Tahun 2004 dari The Institute for Ecosoc Rights bekerjasama dengan Tifa Foundation sebagaimana dikutip dalam Naskah Akademik RUU PPILN sebagai berikut:

1. Ketentuan atau muatan yang tidak melindungi atau merugikan para TKI

Pasal 61 UU Nomor 39 Tahun 2004 yang menugaskan pada PPTKIS untuk mengurus perubahan perjanjian kerja TKI dengan membuat perjanjian kerja baru dan melaporkan kepada Perwakilan RI. Namun, dalam kenyataannya, banyak TKI yang justru mendapatkan kesulitan dengan menyerahkan urusan perjanjian kerja baru dan atau perpanjangan paspor, karena para TKI yang bekerja sebagai PRT sesungguhnya lebih membutuhkan suatu representasi hukum kepembelaan negara daripada sekedar diuruskan oleh pihak PPTKIS yang lebih memiliki kepentingan mendapatkan fee dari proses tersebut. Pasal semacam ini kurang atau 
tidak melindungi para TKI di luar negeri. Pasal ini juga kurang memberikan kejelasan apa yang semestinya dilakukan oleh Perwakilan RI lebih daripada sekedar menerima laporan begitu saja, tanpa peranan perlindungan. Pasal ini selayaknya dikaitkan dengan tugas perlindungan Perwakilan RI secara progresif. ${ }^{37}$

2. Ketentuan atau muatan yang tidak jelas, kabur arti dan implikasinya

Pasal-Pasal yang tidak jelas ini, terbagi dalam beberapa kriteria antara lain yaitu: ${ }^{38}$

a. Pasal-pasal yang mengamanatkan suatu penetapan lebih lanjut. Karena mengandung ketidakjelasan atau kekaburan, maka pasal-pasal ini pada umumnya mengandung pernyataan atau keterangan yang menjelaskan bahwa masalah yang terungkap dalam pasal tersebut akan diatur atau ditetapkan lebih lanjut dengan peraturan yang lain atau keputusan pejabat tinggi tertentu seperti direktur jenderal atau menteri. Contohnya: pasal 6 ayat 3 , pasal 15 ayat 5 , pasal 24 ayat 5 , pasal 25 ayat 4 , pasal 26 ayat 3 , pasal 42 ayat 6 , paal 49 ayat 4 , pasal 62 ayat 3 , pasal 63.

b. Instansi 'terkait'. Karena masih belum jelas siapakah sesungguhnya pihak-pihak lain baik di antara kantor-kantor pemerintah, bisnis maupun masyarakat yang hendak

37 Tim Peneliti The Institute for Ecosoc Rights, Atase Tenaga Kerja dan Perlindungan TKI, antara Indonesia, Singapura dan Malaysia, The Institute for Ecosoc Rights bekerjasama dengan Tifa Foundation, 2010, h. 386. dalam Naskah Akademik Rancangan Undang-Undang Perlindungan Pekerja Indonesia di Luar Negeri (RUU PPILN), $27 \quad$ Mei 2015.2 Diunduh dari http://wikidpr.org/uploads/ruu/56a7b0390d00db504b000027/naskah-akademik-ruuperlindungan-tenaga-kerja-di-luar-negeri-27-mei-2015.pdf, tanggal 3 Juni 2017. ${ }^{38}$ Ibid, hh. 387-388 
bertanggung jawab, berurusan, bekerjasama, dan lain-lain. Dalam penanganan atau pengelolaan masalah-masalah yang dijelaskan dalam pasal tertentu, pasal-pasal tak jelas ini kemudian menambahkan keterangan 'lembaga atau instansi terkait'. Namun, pertanyaannya siapa sesungguhnya pihak lembaga atau instansi tersebut. Jika sama sekali tak jelas, apalagi menyangkut persoalan-persoalan penting seperti masalah 'pembinaan, penyuluhan TKI', maka ketakjelasan ini akan sangat merugikan keperluan perlindungan bagi para TKI.

c. Intransparansi pemerintah. Pasal 15 ayat 1 UU Nomor 39 tahun 2004 menawarkan suatu harapan pada TKI karena dikatakan bahwa seandainya seorang TKI mengalami masalah dan PJTKI tidak mau menanggung masalah TKI tersebut, maka pemerintah akan menanggungnya dengan mengambil uang deposit PJTKI. Namun, karena transparansi kinerja manajemen pemerintah masih belum dapat dipercaya, dan kenyataannya banyak sekali TKI bermasalah yang tak tersantuni oleh pemerintah, maka pasal ini menjadi tidak jelas makna dan manfaatnya bagi perlindungan TKI.

3. Ketentuan atau muatan yang tidak lengkap

Terdapat komponen dari substansi masalah yang diatur dalam UU Nomor 39 tahun 2004 yang secara umum tidak utuh dan tidak jelas sehingga dapat menimbulkan interpretasi yang beragam dan mudah diselewengkan oleh pihak-pihak yang berkepentingan. Ketidakjelasan ini 
menimbulkan ketidakpastian hukum. Hal ini dapat dilihat dalam Pasal 32 ayat 1 s.d. ayat 7. Dari segi bahasanya, substansinya, pasal baik dan jelas maksud dan ungkapan bahasanya, serta langsung terkait dengan kepentingan TKI karena terkait dengan perjanjian kerja yang mengikat nasib TKI selama bekerja di luar negeri. Tetapi pada kenyataannya sangat banyak masalah dilaporkan yang terkait dengan penyelenggaraan perjanjian kerja luar negeri, tentunya terutama dari para TKI itu sendiri. Unsur-unsur penting dalam perjanjian kerja itu terkait dengan substansi seperti gaji, jam kerja. Pasal ini dan ayat-ayatnya justru tidak menyertakan keterlibatan pihak lain di luar PPTKIS dan pemerintah, sehingga pengawasannya pun tentu tak jelas, yang diancangkan mampu mendukung atau merepresentasi kedudukan lemah para TKI dalam proses mencapai perjanjian kerja yang adil. ${ }^{39}$

Contoh lain adalah pasal 35 ayat 1 karena tidak menyebutkan secara lengkap komponen-komponen penting dari kegiatan penyuluhan untuk pendataan para calon TKI. Contoh berikutnya pasal 37 ayat 1 -yang mengatur tentang pendataan para calon TKI-karena tak mempersyaratkan dokumen-dokumen penting yang lain, seperti misalnya dokumen kartu keluarga, yang sesungguhnya dapat menunjang pencegahan perekrutan tidak sah, seperti pemalsuan dokumen. Pasal ini bercelah karena tak memiliki dimensi pencegahan yang sangat diperlukan bagi penanganan perekrutan tidak sah yang terus-menerus terjadi di desa-desa. ${ }^{40}$

\footnotetext{
39 lbid, h. 389

${ }^{40}$ Ibid, h. 390
} 
4. Ketentuan atau muatan saling bertentangan dan inkonsisten

Terdapat beberapa pasal yang menunjukkan adanya inkonistensi dan pasal-pasal yang bertentangan dalam dirinya sendiri, antara lain Pasal 82 yang memberikan wewenang agar PPTKIS 'bertanggung jawab untuk memberikan perlindungan kepada calon TKI/TKI sesuai dengan perjanjian kerja.' Sementara dalam pasal 6 dan pasal 7 menegaskan kewajiban pemerintah untuk memberikan dan meningkatkan upaya perlindungan TKI selama masa sebelum pemberangkatan, masa penempatan, dan masa purna penempatan. Penyerahan kewajiban pemerintah dalam hal perlindungan TKI pada pihak lain yang jelas orientasinya adalah bisnis dan bukan perlindungan, merupakan suatu inkonsistensi. Inkonsistensi ini akan mempengaruhi bentuk sistem pengawasan dan penegakan hukum dalam pelaksanaannya di lapangan.

Dalam UU Nomor 39 tahun 2004, seolah-olah Pemerintah bertanggung jawab dalam keseluruhan proses penempatan dan perlindungan TKI. Namun bila dicermati, banyak tanggung jawab pemerintah yang diserahkan pada PPTKIS. Di satu sisi, beban pemerintah tidaklah ringan, namun tugas perlindungan bukanlah kepentingan dari kalangan bisnis ekspor tenaga kerja. Kepentingan mereka terutama adalah keuntungan sebesar-besarnya. Karenanya tetap beresiko untuk menyerahkan begitu saja tugas-tugas penting konstitusional dalam penempatan kerja luar negeri kepada kalangan bisnis. Terlebih bila pengawasan dan penegakan hukum masih sangat lemah, seperti yang selama ini terjadi. 
Pada bab VI tentang perlindungan, terutama Pasal 82, pasal ini memindahkan terlampau banyak pembebanan tanggung jawab perlindungan yang sesungguhnya menjadi tanggung jawab eksklusif negara (dalam hal ini pemerintah) kepada pihak lain yaitu PPTKIS. Kalangan PPTKIS sendiri berkeluh kesah tentang pembebanan ini terutama sehubungan dengan inkoordinasi kerja di antara lembagalembaga pemerintah sendiri. Sementara itu, Undang-Undang menetapkan bahwa tugas utama pemerintah adalah 'mengatur, membina, melaksanakan dan mengawasi' penyelenggaraan penempatan dan perlindungan, seperti tersurat dalam pasal 5.

Dalam pasal 5 tersebut tak dieksplisitkan tanggung jawab pemerintah sendiri, terutama dalam pengertian secara langsung dan komprehensif, dalam hal penempatan dan perlindungan TKI. Yang terjadi, meskipun secara prinsip pemerintah mengemban seluruh tugas dan kewajiban dalam mengatur, membina, melaksanakan dan mengawasi penyelenggaraan penempatan dan perlindungan TKI di luar negeri, namun dalam pasal-pasal berikutnya pemerintah justru menyerahkan persoalan-persoalan krusial terkait perlindungan TKI - seperti pemberian informasi dan pendidikan bagi TKI pada PPTKIS. Bahkan tanggung jawab untuk mencari sebab kematian TKI - apabila TKI meninggal, juga diserahkan pada PPTKIS.

Mengembalikan tanggung jawab perlindungan TKI pada pemerintah merupakan hal mendesak, terutama mengingat kerentanan TKI ketika bekerja di luar negeri. Sudah selayaknya bahwa tanggung 
jawab utama berada di tangan pemerintah. Apa jadinya dalam kenyataan jika tanggung jawab itu diserahkan kepada pihak pelaku bisnis penempatan tenaga kerja yang kepentingan utamanya bukanlah keamanan dan kesejahteraan para TKI tetapi keuntungan sebesarnya dari bisnis penempatan TKI.

Inkonsistensi lain tampak jelas dalam Pasal 5, Bab II tentang tugas, tanggungjawab dan kewajiban pemerintah, yang menyebutkan bahwa pemerintah bertugas mengatur, membina, melaksanakan dan mengawasi penyelengaraan penempatan dan perlindungan TKI di luar negeri. Pasal ini menyebutkan dua jenis peran atau kerja, yaitu implementasi (mengatur, membina, melaksanakan) dan pengawasan. Pada galibnya kedua tugas ini tak mungkin dilakukan oleh satu pihak saja, yang dalam hal ini adalah pihak pemerintah sendiri. Kedua jenis pekerjaan itu pada umumnya -dalam suatu penyelenggaraan kegiatan publik yang dapat dipertanggungjawabkan, baik dari sisi kepemerintahan maupun dari sisi kodrat kegiatan publik kemasyarakatan secara umum,-- dilakukan oleh setidaknya dua pihak yang mampu mengemban amanat masing-masing. ${ }^{41}$

Sangat sulit bagi seorang pelaksana, yang selain melaksanakan tugasnya, dia sekaligus juga berperan mengawasi kegiatan pelaksanaannya sendiri secara objektif. Jika kedua jenis amanat ini diemban oleh satu pihak saja, maka yang terjadi adalah kontradiksi di dalam dirinya sendiri. Kegiatan melaksanakan justru tidak mungkin dijalankan karena diawasi (dengan pretensi bersikap objektif) oleh dirinya

${ }^{41}$ Ibid, h. 406 
sendiri. Pelaksanaan tak mungkin dicampuradukkan dengan pengawasan. Mutu dari pelaksanaan menjadi tidak absah dan justru menghambat. Dalam ruang lingkup internal suatu bentuk evaluasi masih mungkin dilakukan oleh pelaksana tersebut, tetapi dalam ruang lingkup publik, kedua tugas itu semestinya diemban oleh dua pihak yang berbeda satu dari yang lain. ${ }^{42}$

Pasal mengenai "kewajiban pemerintah" seharusnya memerinci tugas dan tanggung jawab supaya terhindar dari tumpang tindih yaitu: (1) Menteri (Membuat kebijakan, pembinaan dan pengawasan); dan (2) BNP2TKI (Pelaksana kebijakan operasional).

5. Ketentuan atau muatan yang menimbulkan konflik kelembagaan

Pelaksanaan undang-undang merupakan faktor sangat penting, sehingga dalam melakukan tugas untuk kepentingan publik diperlukan dan karenanya diwajibkan adanya suatu koordinasi terpadu di antara para pihak yang terlibat dalam pengelolaan migrasi kerja. Namun, UU Nomor 39 Tahun 2004 justru mengandung suatu ketidakterpaduan di antara lembaga-lembaga yang diamanatkan menjalankan tugas pengelolaan migrasi kerja.

Di satu sisi, yaitu dari sisi (percepatan) pelaksanaan, seperti Pasal 94 dan seterusnya. UU ini mengamanatkan pembentukan suatu badan pelaksana yang disebut dengan Badan Nasional Penempatan dan Perlindungan TKI (BNP2TKI). Sementara itu, di sisi lain, seluruh undangundang ini adalah produk kebijakan pemerintah yang merupakan inisiatif

42 Ibid, h.407 
dari dan berada di bawah wewenang dari seorang Menteri yang mengepalai Departemen Tenaga Kerja dan Transmigrasi (Depnakertrans), dan diangkat untuk membantu tugas Presiden $\mathrm{RI}$ sebagai kepala pemerintah(an) dalam menyelenggarakan pengelolaan migrasi kerja.

Undang-undang ini sendiri tak menjelaskan secara khusus hubungan antara BNP2TKI dan Depnakertrans, apakah masing-masing berdiri sendiri secara terpisah ataukah keduanya wajib melakukan kerja sama. Sebagai suatu bentuk penekanan tugas, suatu pembagian wewenang selayaknya perlu ditegaskan dan ditetapkan, misalnya bahwa Depnakertrans berwewenang dalam menyelenggarakan kebijakan, sementara BNP2TKI bertugas melaksanakannya. Tetapi, keduanya tentunya diandaikan wajib bekerjasama dalam menjalankan amanat undang-undang ini. Pasal-pasal yang mengamanatkan pembentukan BNP2TKI ternyata tak menetapkan secara jelas jenis hubungan kerjasama yang terpadu di antara pemerintah (dalam hal ini Depnakertrans) dan BNP2TKI itu sendiri.

Dampaknya adalah seluruh penetapan pengelolaan migrasi kerja yang telah dijelaskan dalam pasal-pasal sebelumnya menjadi bertumpang tindih tanpa keterpaduan dengan pasal-pasal pembentukan dan fungsi/peran BNP2TKI, juga tanpa spesifikasi pola relasi kerjasama yang wajib ditetapkan dan dijalankan dalam praktik pelaksanaannya. Akibatnya tampak jelas dalam praktik selama ini bahwa koordinasi kerja antara kedua kantor penting dalam melindungi para TKI ini tak mampu 
diwujudkan dan karenanya memacetkan pengelolaan migrasi kerja serta sangat merugikan para TKI.

Pada dasarnya, UU Nomor 39 Tahun 2004 memiliki dua semangat yang tidak sepenuhnya dapat disinergiskan. Pertama, UU ini menghendaki adanya pemenuhan hak setiap orang untuk bisa bekerja dan mendapatkan perlindungan yang pasti dari negara. Kedua, pada banyak pasal, UU ini justru mengedepankan tata niaga (bisnis), dibandingkan pasal-pasal mengenai pelayanan dan perlindungan, termasuk penanganan spesifik terhadap pekerja perempuan. Dalam implementasinya, UU ini memunculkan konflik kepentingan antara pengusaha dengan CTKI/TKI, dan antara instansi Pemerintah, sebagaimana yang dihadapi BNP2TKI dengan Kemenakertrans RI. Dualisme tugas dan wewenang antar instansi mempengaruhi proses penempatan TKI di luar negeri.

Secara keseluruhan UU yang seharusnya bisa dijadikan pedoman hukum, terutama dalam memberikan perlindungan kepada CTKI/TKI, pada akhirnya menjadi bias kepentingan. Oleh karena itu, guna menegaskan posisi keberpihakan pemerintah kepada para calon pekerja/pekerja Indonesia di luar negeri, maka harus segera dilakukan perubahan yang mendasar (penggantian) terhadap UU Nomor 39 Tahun 2004.

Penjelasan di atas mengidentifikasi lima kluster analisis muatan pasal dan ayat antara lain: (1) ketentuan atau muatan yang tidak melindungi atau merugikan $\mathrm{TKI}$, (2) ketenuan atau muatan yang tidak 
jelas, kabur arti dan implikasinya, (3) ketentuan atau muatan yang tidak lengkap, (4) ketentuan atau muatan saling bertentangan dan inkonsisten, dan (5) ketentuan atau muatan yang menimbulkan konflik kelembagaan. Kluster pertama menyorot praktek perubahan maupun pembuatan perjanjian kerja yang diserahkan kepada PPTKIS yang dikhawatirkan memiliki kepentingan mendapatkan keuntungan dari proses tersebut, padahal peran negara melalui perwakilan RI dibutuhkan oleh TKI. Kluster kedua membagi pasal-pasal yang tidak jelas kedalam tiga kriteria yakni pasal-pasal yang mengamanatkan suatu penetapan lebih lanjut seperti pasal-pasal yang menjelaskan bahwa masalah yang terungkap dalam pasal tertentu akan diatur atau ditetapkan lebih lanjut dengan peraturan yang lain atau keputusan pejabat tinggi tertentu, pemaknaan instansi terkait yang kabur dan intransparansi pemerintah seperti dalam manajemen pemerintah untuk memediasi antara TKI bermasalah dan ketidakmampuan PPTKIS untuk memberikan kompensasi.

Kluster ketiga menitikberatkan pada pasal yang tidak utuh dan tidak jelas sehingga dapat menimbulkan interpretasi yang beragam dan mudah diselewengkan, dicontohkan pada pasal terkait perjanjian kerja yang banyak mengalami permasalahan serta keterlibatan para pihak yang terbatas hanya melibatkan PPTKIS dan pemerintah, contoh lain mengenai pendataan calon TKI yang kurang dilengkapi dokumen penting seperti Kartu Keluarga untuk mencegah perekrutan yang tidak sah.

Kluster keempat menyorot pasal-pasal yang menunjukkan adanya inkonsistensi dan bertentangan dengan pasal itu sendiri, seperti pasal 
yang memberikan wewenang kepada PPTKIS untuk memberikan perlindungan, sedangkan pada pasal lain disebutkan bahwa pemerintah bertanggungjawab untuk seluruh proses penempatan dari berangkat hingga kembali lagi ke tanah air. Pelimpahan tanggungjawab dari pemerintah kepada pihak swasta memunculkan permasalahan terabaikannya perlindungan terhadap TKI dikarenakan kepentingan dari PPTKIS adalah mendapatkan keuntungan sebesar-besarnya dari bisnis yang dijalankan. Sehingga tanggungjawab perlindungan TKI harus dikembalikan kepada pemerintah agar dijalankan secara efektif dan terkoordinasi. Pasal inkonsisten lainnya terkait dengan tugas, tanggungjawab dan kewajiban pemerintah yang menyebutkan pemerintah bertugas mengatur, membina, melaksanakan dan mengawasi. Tugastugas ini tentu tidak dapat dilakukan oleh satu pihak saja, sehingga perlu dirinci tugas dan tanggungjawab tersebut untuk menghindari tumpang tindih yaitu: menteri sebagai pembuat kebijakan, pembina dan pengawas dan BNP2TKI sebagai pelaksana kebijakan operasional.

Kluster kelima menekankan pada pasal-pasal yang menimbulkan konflik kelembagaan, seperti pasal yang mengamanatkan pembentukan BNP2TKI, namun di sisi lain UU ini merupakan produk kebijakan pemerintah yang berada di bawah wewenang dari Menteri yang membidangi Ketenagakerjaan. UU ini tidak menjelaskan secara khusus hubungan antara BNP2TKI dan Kementerian Ketenagakerjaan, apakah masing-masing berdiri secara terpisah atau keduanya wajib melakukan kerjasama. Akibatnya pelaksanaan UU ini masih belum menunjukkan 
sinergitas dan koordinasi kerja antara kedua institusi yang menjadi tempat bernaung para TKI.

Dalam melakukan harmonisasi peraturan perundang-undangan ada beberapa hal yang perlu diperhatikan. Hal ini disampaikan Bapak Yuli dari Kementerian Ketenagakerjaan RI dalam wawancaranya dengan peneliti, berikut pernyataannya:

"Saat ini rancangan perubahan UU No. 39 Tahun 2004 sudah masuk dalam prolegnas (program legislasi nasional). Adapun proses harmonisasi antara konvensi internasional yang sudah diratifikasi perlu disesuaikan dengan kondisi nasional. Walaupun isinya baik. Diskusi-diskusi internal perlu diintensifkan dalam mengoptimalkan upaya memberikan perlindungan yang lebih bagi TKI, serta mengakomodir semua pekerja Indonesia di luar negeri. Dimana perlindungan yang diberikan berlaku di semua tahapan penempatan TKI (universal)" 43

Pendapat di atas menunjukkan bahwa UU No. 39 Tahun 2004 telah kembali menjalani proses menuju perubahan yang telah dimasukkan dalam program legislasi nasional (prolegnas). Adapun konvensi internasional yang telah disahkan melalui proses ratifikasi, walaupun kontennya telah dianggap baik (dalam mengarusutamakan perlindungan pekerja migran) tetapi masih perlu disesuaikan dengan kondisi dan kebutuhan Indonesia. Sehingga tujuan untuk memberikan perlindungan bagi seluruh pekerja Indonesia di luar negeri dapat dirasakan manfaatnya secara menyeluruh (komprehensif) di setiap tahapan penempatan (universal).

Kepala Biro Hukum dan Hubungan Masyarakat Badan Nasional Penempatan dan Perlindungan TKI (BNP2TKI), Ramiany Sinaga

${ }^{43}$ Wawancara dengan Bapak Yuli, Direktorat PPTKLN, Dirjen Binapenta dan PKK, Kementerian Ketenagakerjaan RI, 30 Januari 2017 di Kantor Kementerian Ketenagakerjaan RI, Jakarta. 
menjelaskan bahwa masih ada hambatan-hambatan dalam pelaksanaan UU No. 39 Tahun 2004 antara lain:

"Tidak bisa diterapkannya UU No. 39 Tahun 2004 kepada TKI profesional, pengaturan UU masih terbatas pada PRT yang pada saat perumusannya proporsi jumlah TKI informal masih lebih besar daripada TKI formal, namun demikian kondisi penempatan TKI saat ini telah berubah. Tidak jelas siapa melakukan apa, serta adanya blank mandat dalam UU". ${ }^{44}$

Pernyataan di atas memberikan gambaran bahwa dalam perspektif pelaksana penempatan dan perlindungan TKI yang diberi amanat oleh Undang-Undang, masih menemukan hambatan-hambatan dalam pelaksanaan UU No. 39 Tahun 2004. Pertama mengenai penerapan UU kepada TKI profesional, hal ini perlu diperhatikan mengingat pada akhir 2015 lalu Indonesia telah resmi masuk dalam era Masyarakat ASEAN, sehingga pengaturan TKI juga harus diarahkan pada penempatan TKI profesional di kawasan Asia Tenggara maupun negara yang membutuhkan. Kedua, proporsi penempatan TKI yang masih didominasi oleh Penata Laksana Rumah Tangga (PLRT) atau Pembantu Rumah Tangga (PRT) pada saat penyusunan UU No. 39 Tahun 2004 sampai sekarang perlu diperhitungkan kembali, karena trend penempatan TKI telah bergeser dari TKI informal dengan proporsi terbesar, menjadi seimbang dengan permintaan terhadap TKI di sektor formal. Ketiga, koordinasi antar-lembaga perlu ditingkatkan untuk menghindari ketidakjelasan/tumpang tindih terkait tugas, wewenang dan tanggung jawab masing-masing. Keempat, terkait dengan blank mandat pada UU perlu diperhatikan agar dikurangi pada UU yang akan dirubah.

\footnotetext{
${ }^{44}$ Wawancara dengan Ramiany Sinaga, Kepala Biro Hukum dan Humas BNP2TKI, 30 Januari 2017 di Kantor BNP2TKI JI. MT Haryono, Jakarta.
} 
Setelah mengevaluasi pelaksanaan UU No. 39 Tahun 2004, dilanjutkan dengan mengkaji peraturan perundang-undangan terkait penempatan dan perlindungan TKI di luar negeri. Pengkajian ini didasarkan pada tipe penelitian ini yakni taraf sinkronisasi vertikal dan horizontal yakni mengkaji perundang-undangan yang sederajat maupun derajatnya berbeda-beda namun masih mengatur bidang yang sama. Sehingga, harmonisasi ini mengacu pada bidang yang terkait serta menjadi sistem pendukung dalam penempatan dan perlindungan TKI di luar negeri. Kajian peraturan terkait dibagi ke dalam dua kategori yakni hukum nasional dan hukum hasil ratifikasi, sebagai berikut:

\section{Hukum Nasional}

1. Undang-Undang Dasar Negara Republik Indonesia Tahun 1945 Republik Indonesia

Pembukaan Undang-Undang Dasar Negara Republik Indonesia Tahun 1945 Paragraf Keempat menjelaskan bahwa Negara berkewajiban untuk melindungi segenap bangsa Indonesia termasuk warga Negara Indonesia untuk memajukan kesejahterahan umum. Mencari dan mendapatkan pekerjaan yang layak merupakan salah satu upaya manusia untuk memperoleh kesejahterahan. Sedangkan lapangan pekerjaan yang tersedia didalam negeri belum dapat memenuhi kebutuhan akan lapangan pekerjaan bagi warga Negara Indonesia, Oleh karena itu masyarakatyang terdesak oleh kebutuhan ekonomi berupaya memperoleh pekerjaan di Luar Negeri. Hal ini didukung oleh Pasal 27 ayat 2 Undang-Undang Dasar Negara Republik Indonesia menjelaskan bahwa setiap warga Negara Indonesia berhak mendapatkan pekerjaan dan penghidupan yang layak 
bagi kemanusiaan. Penghidupan yang layak akan sulit terwujud apabila melihat sulitnya menemukan lapangan pekerjaan dan mendapatkan upah yang dapat meningkatkan kesejahterahan. Keadaan tersebut mendukung Warga Negara Indonesia untuk mencari lapangan pekerjaan tidak hanya didalam negeri, tetapi mencari lapangan pekerjaan yang sesuai di Luar negeri. Pembukaan Undang-Undang Dasar Negara Republik Indonesia Tahun 1945 beserta Pasal 27 ayat 2 akan sulit dilaksanakan untuk mewujudkan —cita-cita bangsa Indonesia untuk menuju kehidupan yang sejahtera.

Bab XA tentang Hak Asasi Manusia dijelaskan pada Pasal 28D ayat 2 secara tegas disebutkan bahwa setiap orang berhak untuk bekerja serta mendapatkan imbalan dan perlakuan yang adil dan layak dalam hubungan kerja. Perlindungan yang wajib dilakukan pemerintah terbukti tidak hanya sampai pada kewajiban pemerintah untuk menyediakan lapangan pekerjaan saja, melainkan hingga perlindungan terhadap warga negaranya dalam mewujudkan hubungan kerja yang tidak merugikan warga negarannya. Peran pemerintah untuk mewujudkan nilai-nilai yang diatur dalam Undang-Undang Dasar Negara Republik Indonesia kemudian diwujudkan dalam sejumlah produk kebijakan yang dibentuk untuk menjawab kebutuhan warga negaranya.

Oleh karena itu dituntut adanya produk kebijakan yang dapat melindungi hak Warga Negara Indonesia sesuai dengan konstitusi Negara Indonesia yang tercantum pada pembukaan hingga batang tubuh sebagai cita bangsa Indonesia. Kehadiran UU Nomor 39 Tahun 2004 tentang 
Penempatan dan Perlindungan Tenaga Kerja di Luar Negeri selain Undang-Undang Ketenagakerjaan merupakan suatu bukti dari kehadiran Negara dalam menangani masalah perlindungan warga Negara Indonesia yang mencari pekerjaan di Luar Negeri untuk memenuhi kesejahteraannya.

2. Kitab Undang-Undang Hukum Pidana

Dalam Pengelolaan Pekerja Indonesia pada masa pra penempatan, masa penempatan dan pascapenempatan banyak terdapat pelanggaran maupun tindak kejahatan yang terjadi dan merugikan Pekerja Indonesia itu sendiri. Oleh karena itu, terdapat beberapa jenis tindak kejahatan yang terdapat dalam Kitab Undang-Undang Hukum Pidana sebagai berikut:

1) Tipu daya/muslihat (deception), tercantum dalam Pasal 378 KUHP yang berisi "Barang siapa dengan maksud untuk menguntungkan diri sendiri atau orang lain secara melawan hukum, dengan memakai nama palsu atau martabat palsu, dengan tipu muslihat, ataupun rangkaian kebohongan, menggerakkan orang lain untuk menyerahkan barang sesuatu kepadanya, atau supaya memberi hutang rnaupun menghapuskan piutang diancam karena penipuan dengan pidana penjara paling lama empat tahun".

2) Ancaman atau penggunaan kekerasan fisik atau seksual, tercantum dalam Pasal 285-301, 335-336, 351-355, 368, 506 KUHP.

Pasal 285

Barang siapa dengan kekerasan atau ancaman kekerasan memaksa seorang wanita bersetubuh dengan dia di luar perkawinan, diancam karena melakukan perkosaan dengan pidana penjara paling lama dua belas tahun.

Pasal 286 
Barang siapa bersetubuh dengan seorang wanita di luar perkawinan, padahal diketahui bahwa wanita itu dalam keadaan pingsan atau tidak berdaya, diancam dengan pidana penjara paling lama sembilan tahun.

Pasal 287

(1) Barang siapa bersetubuh dengan seorang wanita di luar perkawinan, padahal diketahuinya atau sepatutnya harus diduganya bahwa umumya belum lima belas tahun, atau kalau umurnya tidak jelas, bawa belum waktunya untuk dikawin, diancam dengan pidana penjara paling lama sembilan tahun.

(2) Penuntutan hanya dilakukan atas pengaduan, kecuali jika umur wanita belum sampai dua belas tahun atau jika ada salah satu hal berdasarkan pasal 291 dan pasal 294.

Pasal 288

(1) Barang siapa dalam perkawinan bersetubuh dengan seorang wanita yang diketahuinya atau sepatutnya harus diduganya bahwa yang bersangkutan belum waktunya untuk dikawin, apabila perbuatan mengakibatkan luka-luka diancam dengan pidana penjara paling lama empat tahun.

(2) Jika perbuatan mengakibatkan luka-luka berat, dijatuhkan pidana penjara paling lama delapan tahun.

(3) Jika mengakibatkan mati, dijatuhkan pidana penjara paling lama dua belas tahun.

Pasal 289

Barang siapa dengan kekerasan atau ancaman kekerasan memaksa seorang untuk melakukan atau membiarkan dilakukan perbuatan cabul, diancam karena melakukan perbuatan yang menyerang kehormatan kesusilaan, dengan pidana penjara paling lama sembilan tahun.

Pasal 290

Diancam dengan pidana penjara paling lama tujuh tahun: 
1. barang siapa melakukan perbuatan cabul dengan seorang, padahal diketahuinya bahwa orang itu pingsan atau tidak berdaya;

2. barang siapa melakukan perbuatan cabul dengan seorang padahal diketahuinya atau sepatutnya harus diduganya, bahwa umumya belum lima belas tahun atau kalau umumya tidak jelas, yang bersangkutan belum waktunya untuk dikawin:

3. barang siapa membujuk seseorang yang diketahuinya atau sepatutnya harus diduganya bahwa umurnya belum lima belas tahun atau kalau umumya tidak jelas yang bersangkutan atau kutan belum waktunya untuk dikawin, untuk melakukan atau membiarkan dilakukan perbuatan cabul, atau bersetubuh di luar perkawinan dengan orang lain.

Pasal 291

(1) Jika salah satu kejahatan berdasarkan pasal 286, 2 87, 289, dan 290 mengakibatkan luka-luka berat, dijatuhkan pidana penjara paling lama dua belas tahun;

(2) Jika salah satu kejahatan berdasarkan pasal 285, 2 86, 287, 289 dan 290 mengakibatkan kematisn dijatuhkan pidana penjara paling lama lima belas tahun.

Pasal 292

Orang dewasa yang melakukan perbuatan cabul dengan orang lain sesama kelamin, yang diketahuinya atau sepatutnya harus diduganya belum dewasa, diancam dengan pidana penjara paling lama lima tahun.

Pasal 293

(1) Barang siapa dengan memberi atau menjanjikan uang atau barang, menyalahgunakan pembawa yang timbul dari hubungan 
keadaan, atau dengan penyesatan sengaja menggerakkan seorang belum dewasa dan baik tingkahlakunya untuk melakukan atau membiarkan dilakukan perbuatan cabul dengan dia, padahal tentang belum kedewasaannya, diketahui atau selayaknya harus diduganya, diancam dengan pidana penjara paling lama lima tahun.

(2) Penuntutan hanya dilakukan atas pengaduan orang yang terhadap dirinya dilakukan kejahatan itu.

(3) Tenggang waktu tersebut dalam pasal 74 bagi pengaduan ini adalah masing-masing sembilan bulan dan dua belas bulan.

Pasal 294

(1) Barang siapa melakukan perbuatan cabul dengan anaknya, tirinya, anak angkatnya, anak di bawah pengawannya yang belum dewasa, atau dengan orang yang belum dewasa yang pemeliharaanya, pendidikan atau penjagaannya diannya yang belum dewasa, diancam dengan pidana penjara paling lama tujuh tahun.

(2) Diancam dengan pidana yang sama:

1. pejabat yang melakukan perbuatan cabul dengan orang yang karena jabatan adalah bawahannya, atau dengan orang yang penjagaannya dipercayakan atau diserahkan kepadanya,

2. pengurus, dokter, guru, pegawai, pengawas atau pesuruh dalam penjara, tempat pekerjaan negara, tempat pendidikan, rumah piatu, rumah sakit, rumah sakit jiwa atau lembaga sosial, yang melakukan perbuatan cabul dengan orang yang dimasukkan ke dalamnya.

Pasal 295

(1) Diancam:

1. dengan pidana penjara paling lama lima tahun barang siapa dengan sengaja menyebabkan atau memudahkan dilakukannya perbuatan cabul oleh anaknya, anak tirinya, 
anak angkatnya, atau anak di bawah pengawasannya yang belum dewasa, atau oleh orang yang belum dewasa yang pemeliharaannya, pendidikan atau penjagaannya diserahkan kepadanya, ataupun oleh bujangnya atau bawahannya yang belum cukup umur, dengan orang lain;

2. dengan pidana penjara paling lama empat tahun barang siapa dengan sengaja menghubungkan atau memudahkan perbuatan cabul, kecuali yang tersebut dalam butir 1 di atas., yang dilakukan oleh orang yang diketahuinya belum dewasa atau yang sepatutnya harus diduganya demikian, dengan orang lain.

(2) Jika yang bersalah melakukan kejahatan itu sebagai pencarian atau kebiasaan, maka pidana dapat ditambah sepertiga.

Pasal 296

Barang siapa dengan sengaja menyebabkan atau memudahkan perbuatan cabul oleh orang lain dengan orang lain, dan menjadikannya sebagai pencarian atau kebiasaan, diancam dengan pidana penjara paling lama satu tahun empat bulan atau pidana denda paling banyak lima belas ribu rupiah.

Pasal 297

Perdagangan wanita dan perdagangan anak laki-laki yang belum dewasa, diancam dengan pidana penjara paling lama enam tahun. Pasal 298

(1) Dalam hal pemidanaan berdasarkan salah satu kejahatan dalam pasal 281, 284 - 290 dan 292 - 297, pencabutan hak-hak berdasarkan pasal 35 No. 1 - 5 dapat dinyatakan.

(2) Jika yang bersalah melakukan salah satu kejahatan berdasarkan pasal 292 - 297 dalam melakukan pencariannya, maka hak untuk melakukan pencarian itu dapat dicabut.

Pasal 299 
(1) Barang siapa dengan sengaja mengobati seorang wanita atau menyuruh supaya diobati, dengan diberitahukan atau ditimbulkan harapan bahwa karena pengobatan itu hamilnya dapat digugurkan, diancam dengan pidana penjara paling lama empat tahun atau pidana denda paling banyak empat puluh lima ribu rupiah.

(2) Jika yang bersalah berbuat demikian untuk mencari keuntungan, atau menjadikan perbuatan tersebut sebagai pencarian atau kebiasaan, atau jika dia seorang tabib, bidan atau juru-obat, pidananya dapat ditambah sepertiga

(3) Jika yang bersalah melakukan kejahatan tersebut dalam menjalankan pencariannya, dapat dicabut haknya untuk menjalakukan pencarian itu.

Pasal 300

(1) Diancam dengan pidana penjara paling lama satu tahun atau denda paling banyak empat ribu lima ratus rupiah:

1. barang siapa dengan sengaja menjual atau memberikan minuman yang memabukkan kepada seseorang yang telah kelihatan mabuk; Perdagangan wanita dan perdagangan anak laki-laki yang belum dewasa, diancam dengan pidana penjara paling lama enam tahun.

2. barang siapa dengan sengaja membikin mabuk seorang anak yang umurnya belum cukup enam belas tahun;

3. barang siapa dengan kekerasan atau ancaman kekerasan memaksa orang untuk minum minuman yang memabukan.

(2) Jika perbuatan mengakibatkan luka-luka berat, yang bersalah diancam dengan pidana penjara paling lama tujuh tahun.

(3) Jika perbuatan mengakibatkan kematian, yang bersalah diancam dengan pidana penjara paling lama sembilan tahun.

(4) Jika yang bersalah melakukan kejahatan tersebut dalam menjalankan pencariannya, dapat dicabut haknya untuk menjalankan pencarian itu. 
Pasal 301

Barang siapa memberi atau menyerahkan kepada orang lain seorang anak yang ada di bawah kekuasaannya yang sah dan yang umumya kurang dari dua belas tahun, padahal diketahui bahwa anak itu akan dipakai untuk atau di waktu melakukan pengemisan atau untuk pekerjaan yang berbahaya, atau yang dapat merusak kesehatannya, diancam dengan pidana penjara paling lama empat tahun.

Pasal 335

(1) Diancam dengan pidana penjara paling lama satu tahun atau denda paling banyak empat ribu lima ratus rupiah:

1. barang siapa secara melawan hukum memaksa orang lain supaya melakukan, tidak melakukan atau membiarkan sesuatu, dengan memakai kekerasan, sesuatu perbuatan lain maupun perlakuan yang tak menyenangkan, atau dengan memakai ancaman kekerasan, sesuatu perbuatan lain maupun perlakuan yang tak menyenangkan, baik terhadap orang itu sendiri maupun orang lain;

2 barang siapa memaksa orang lain supaya melakukan, tidak melakukan atau membiarkan sesuatu dengan ancaman pencemaran atau pencemaran tertulis.

(2) Dalam hal sebagaimana dirumuskan dalam butir 2, kejahatan hanya dituntut atas pengaduan orang yang terkena.

Pasal 336

(1) Diancam dengan pidana penjara paling lama dua tahun delapan bulan, barang siapa mengancam dengan kekerasan terhadap orang atau barang secara terang-terangan dengan tenaga bersama, dengan suatu kejahatan yang menimbulkan bahaya umum bagi keamanan orang atau barang, dengan perkosaan atau perbuatan yang melanggar kehormatan kesusilaan, dengan sesuatu kejahatan terhadap nyawa, dengan penganiayaan berat atau dengan pembakaran. 
(2) Bilamana ancaman dilakukan secara tertulis dan dengan syarat tertentu, maka dikenakan pidana penjara paling lama lima tahun.

\section{Pasal 351}

(1) Penganiayaan diancam dengan pidana penjara paling lama dua tahun delapan bulan atau pidana denda paling banyak empat ribu lima ratus rupiah,

(2) Jika perbuatan mengakibatkan luka-luka berat, yang bersalah diancam dengan pidana penjara paling lama lima tahun.

(3) Jika mengakibatkan mati, diancam dengan pidana penjara paling lama tujuh tahun.

(4) Dengan penganiayaan disamakan sengaja merusak kesehatan.

(5) Percobaan untuk melakukan kejahatan ini tidak dipidana.

\section{Pasal 352}

(1) Kecuali yang tersebut dalam Pasal 353 dan 356, maka penganiayaan yang tidak menimbulkan penyakit atau halangan untuk menjalankan pekerjaan jabatan atau pencarian, diancam, sebagai penganiayaan ringan, dengan pidana penjara paling lama tiga bulan atau pidana denda paling banyak empat ribu lima ratus rupiah. Pidana dapat ditambah sepertiga bagi orang yang melakukan kejahatan itu terhadap orang yang bekerja padanya, atau menjadi bawahannya.

(2) Percobaan untuk melakukan kejahatan ini tidak dipidana.

Pasal 353

(1) Penganiayaan dengan rencana lebih dahulu, diancam dengan pidana penjara paling lama empat tahun.

(2) Jika perbuatan itu mengakibatka luka-luka berat, yang bersalah dikenakan pidana penjara paling lama tujuh tahun.

(3) Jika perbuatan itu mengkibatkan kematian yang bersalah diancam dengan pidana penjara paling lama sembilan tahun 
Pasal 354

(1) Barang siapa sengaja melukai berat orang lain, diancam karena melakukan penganiayaan berat dengan pidana penjara paling lama delapan tahun.

(2) Jika perbuatan itu mengakibatkan kematian, yang bersalah diancam dengan pidana penjara paling lama sepuluh tahun.

Pasal 355

(1) Penganiayaan berat yang dilakukan dengan rencana terlebih dahulu, diancam dengan pidana penjara paling lama dua belas tahun.

(2) Jika perbuatan itu mengakibatkan kematian, yang bersalah diancam dengan pidana penjara paling lama lima belas tahun.

Pasal 368

(1) Barang siapa dengan maksud untuk menguntungkan diri sendiri atau orang lain secara melawan hukum, memaksa seorang dengan kekerasan atau ancaman kekerasan untuk memberikan barang sesuatu, yang seluruhnya atau sebagian adalah kepunyaan orang itu atau orang lain, atau supaya membuat hutang maupun menghapuskan piutang, diancam karena pemerasan dengan pidana penjara paling lama sembilan bulan.

(2) Ketentuan pasal 365 ayat kedua, ketiga, dan keempat berlaku bagi kejahatan ini.

Pasal 506

Barang siapa menarik keuntungan dari perbuatan cabul seorang wanita dan menjadikannya sebagai pencarian, diancam dengan pidana kurungan paling lama satu tahun.

3) Ancaman melaporkan pekerja kepada pihak berwajib tercantum dalam Pasal 328, 369 KUHP.

Pasal 328

Barang siapa membawa pergi seorang dari tempat kediamannya atau tempat tinggalnya sementara dengan maksud untuk menempatkan orang itu secara melawan hukum di bawah 
kekuasaannya atau kekuasaan orang lain, atau untuk menempatkan dia dalam keadaan sengsara, diancam karena penculikan dengan pidana penjara paling lama dua belas tahun.

Pasal 369

(1) Barang siapa dengan maksud untuk menguntungkan diri sendiri atau orang lain secara melawan hukum. dengan ancaman pencemaran baik dengan lisan maupun tulisan, atau dengan ancaman akan membuka rahasia, memaksa seorang supaya memberikan barang sesuatu yang seluruhnya atau sebagian kepunyaan orang itu atau orang lain. atau supaya membuat hutang atau menghapuskan piutang, diancam dengan pidana penjara paling lama empat tahun.

(2) Kejahatan ini tidak dituntut kecuali atas pengaduan orang yang terkena kejahatan.

4) Pekerja menemukan dirinya berada dalam situasi serupa perbudakan dan/atau pekerja dijual kepada/dibeli oleh majikan tercantum dalam Pasal 289, 295 (anak-anak), 296, 297, 324, 328, 335-336, 351-355, 368-369, 506 KUHP.

Pasal 296

Barang siapa dengan sengaja menyebabkan atau memudahkan perbuatan cabul oleh orang lain dengan orang lain, dan menjadikannya sebagai pencarian atau kebiasaan, diancam dengan pidana penjara paling lama satu tahun empat bulan atau pidana denda paling banyak lima belas ribu rupiah.

\section{Pasal 297}

Perdagangan wanita dan perdagangan anak laki-laki yang belum dewasa, diancam dengan pidana penjara paling lama enam tahun.

5) Penyalahgunaan kekuasaan atau otoritas tercantum dalam Pasal 263, 328, 362, 365 KUHP.

Pasal 263 
(1) Barang siapa membuat surat palsu atau memalsukan surat yang dapat menimbulkan sesuatu hak, perikatan atau pembebasan hutang, atau yang diperuntukkan sebagai bukti daripada sesuatu hal dengan maksud untuk memakai atau menyuruh orang lain memakai surat tersebut seolah-olah isinya benar dan tidak dipalsu, diancam jika pemakaian tersebut dapat menimbulkan kerugian, karena pemalsuan surat, dengan pidana penjara paling lama enam tahun.

(2) Diancam dengan pidana yang sama, barang siapa dengan sengaja memakai surat palsu atau yang dipalsukan seolah-olah sejati, jika pemakaian surat itu dapat menimbulkan kerugian.

6) Intimidasi dan/atau penggunaan ancaman melakukan tindakan balasan: (Pasal 328, 335-336, 369 KUHP).

7) Ancaman untuk menyebarkan informasi kepada keluarga atau masyarakat: (Pasal 369, 328 KUHP).

8) Penggunaan surat-surat identitas palsu: (Pasal 263, 277, 328, 369 KUHP).

\section{Pasal 277}

(1) Barang siapa dengan salah satu perbuatan sengaja menggelapkan asal-usul orang, diancam karena penggelapan asal-usul, dengan pidana penjara paling lama enam tahun.

(2) Pencabutan hak berdasarkan Pasal 35 No.1-4 dapat dinyatakan.

9) Penculikan tercantum dalam Pasal 332-334 KUHP. Pasal 332

(1) Bersalah melarikan wanita diancam dengan pidana penjara;

1. paling lama tujuh tahun, barang siapa membawa pergi seorang wanita yang belum dewasa, tanpa dikehendaki orang tuanya atau walinya tetapi dengan persetujuannya. dengan maksud untuk memastikan penguasaan terhadap wanita itu, baik di dalam maupun di luar perkawinan; 
2. paling lama sembilan tahun, barang siapa membawa pergi seorang wanita dengan tipu muslihat, kekerasan atau ancaman kekerasan, dengan maksud untuk memastikan penguasaannya terhadap wanita itu, baik di dalam maupun di luar perkawinan.

(2) Penuntutan hanya dilakukan atas pengaduan.

(3) Pengaduan dilakukan:

a. jika wanita ketika dibawa pergi belum dewasa, oleh dia sendiri atau orang lain yang harus memberi izin bila dia kawin;

b. jika wanita ketika dibawa pergi sudah dewasa, oleh dia sendiri atau oleh suaminya.

(4) Jika yang membawa pergi lalu kawin dengan wanita yang dibawa pergi dan terhadap perkawinan itu berlaku aturan aturan Burgerlijk Wetboek, maka tak dapat dijatuhkan pidana sebelum perkawinan itu dinyatakan batal.

Pasal 333

(1) Barang siapa dengan sengaja dan melawan hukum merampas kemerdekaan seseorang, atau meneruskan perarnpasan kemerdekaan yang demikian, diancam dengan pidana penjara paling lama delapan tahun.

(2) Jika perbuatan itu mengakibatkan luka-luka berat maka yang bersalah diancam dengan pidana penjara paling lama sembilan tahun.

(3) Jika mengakibatkan mati diancam dengan pidana penjara paling lama dua belas tahun.

(4) Pidana yang ditentukan dalam pasal ini diterapkan juga bagi orang yang dengan sengaja dan melawan hukum memberi tempat untuk perampasan kemerdekaan.

Pasal 334

(1) Barang siapa karena kealpaannya menyebabkan seorang dirampas kemerdekaannya secara melawan hukum, atau 
diteruskannya perampasan kemerdekaan yang demikian, diancam dengan pidana kurungan paling lama tiga bulan atau pidana denda paling banyak tiga ratus rupiah.

(2) Jika perbuatan itu mengakibatkan luka-luka berat, maka yang bersalah diancam dengan pidana kurungan paling lama sembilan bulan.

(3) Jika mengakibatkan mati, diancam dengan pidana kurungan paling lama satu tahun.

10)Perampasan atau pembatasan kebebasan bergerak: (Pasal 333$334 \mathrm{KUHP})$.

11)Penahanan upah atau penolakan untuk membayar upah pekerja: (Pasal 362, 368, 328, 378 KUHP).

\section{Pasal 378}

Barang siapa dengan maksud untuk menguntungkan diri sendiri atau orang lain secara melawan hukum, dengan memakai nama palsu atau martabat palsu, dengan tipu muslihat, ataupun rangkaian kebohongan, menggerakkan orang lain untuk menyerahkan barang sesuatu kepadanya, atau supaya memberi hutang rnaupun menghapuskan piutang diancam karena penipuan dengan pidana penjara paling lama empat tahun.

12)Penahanan paspor dan/atau surat-surat identitas lainnya: (Pasal 362 KUHP (tergantung pada intensi (maksud) dari orang yang mengambil/menahan paspor), atau perbuatan tersebut dapat dipandang sebagai bagian dari pelanggaran lain, (Pasal 328, 333, 378 KUHP).

13)Pengambilan, penyitaan atau perampasan barang-barang milik pribadi, (Pasal 362 KUHP (tergantung pada maksud dari pelaku yang mengambil barang-barang milik pribadi pekerja tersebut), atau perbuatan tersebut dapat dipandang sebagai bagian dari pelanggaran lain, (Pasal 328, 333 atau $378 \mathrm{KUHP}$ ).

14)Debt bondage (Penjeratan Utang) atau pemerasan: (Pasal 328, 368, 369, 378 KUHP). 
3. Kitab Undang-Undang Hukum Perdata

Perjanjian kerja adalah suatu perjanjian antara pekerja dan pengusaha secara lisan dan/atau tertulis, baik untuk waktu tertentu maupun untuk waktu tidak tertentu yang memuat syarat-syarat kerja, hak dan kewajiban. Perjanjian kerja menurut pasal 1601a KUH Perdata adalah suatu perjanjian di mana pihak yang satu, buruh, mengikatkan diri untuk bekerja pada pihak yang lain, majikan, selama suatu waktu tertentu dengan menerima upah. Dari bunyi pasal tersebut dapat dikatakan bahwa yang dinamakan Perjanjian Kerja harus memenuhi persyaratanpersyaratan sebagai berikut:

a. Ada orang di bawah pimpinan orang lain. Berarti ada unsur wenang perintah. Dalam Perjanjian Kerja ini unsur wenang perintah ini memegang peranan pokok sebab tanpa adanya unsur wenang perintah, berarti bukan Perjanjian Kerja. Adanya unsur wenang perintah berarti antara kedua belah pihak ada kedudukan yang tidak sama. Kedudukan yang tidak sama ini diatur ada sub-ordinasi artinya ada pihak yang kedudukannya di atas (Yang memerintah) dan ada pihak yang kedudukannya di bawah (yang diperintah).

b. Penunaian Kerja. Maksudnya melakukan pekerjaan.

c. Dalam Waktu Tertentu. Maksudnya dalam Penunaian Kerja, pribadi manusia sangat tersangkut kepada kerja. Tersangkutnya pribadi manusia akan berakhir dengan adanya waktu tertentu. 
d. Adanya Upah. Upah adalah suatu penerimaan sebagai imbalan dari pengusaha kepada buruh untuk sesuatu pekerjaan atau jasa yang telah atau akan dilakukan, dinyatakan atau dinilai dalam bentuk uang yang ditetapkan menurut suatu persetujuan atau peraturan perundang-undangan, dan dibayarkan atas dasar suatu perjanjian kerja antara pengusaha dengan buruh, termasuk tunjangan baik untuk buruh sendiri maupun keluarganya (Pasal 1 huruf a Peraturan Pemerintah Nomor 8 Tahun 1981 tentang Perlindungan Upah). Yang dimaksud dengan imbalan, termasuk juga sebutan honorarium yang diberikan oleh pengusaha kepada buruh secara teratur dan terus-menerus.

Syarat sahnya kontrak (perjanjian)

Menurut Pasal 1338 ayat (1) bahwa perjanjian yang mengikat hanyalah perjanjian yang sah. Supaya sah pembuatan perjanjian harus mempedomani Pasal 1320 KUH Perdata. Pasal 1320 KUHPerdata menentukan empat syarat sahnya perjanjian yaitu harus ada:

1. Kesepakatan. Yang dimaksud dengan kesepakatan di sini adalah adanya rasa ikhlas atau saling memberi dan menerima atau sukarela di antara pihak-pihak yang membuat perjanjian tersebut. Kesepakatan tidak ada apabila kontrak dibuat atas dasar paksaan, penipuan, atau kekhilafan.

2. Kecakapan. Berarti para pihak yang membuat kontrak haruslah orang-orang yang oleh hukum dinyatakan sebagai subyek 
hukum. Pada dasarnya semua orang menurut hukum cakap untuk membuat kontrak. Yang tidak cakap adalah orang-orang yang ditentukan oleh hukum, yaitu anak-anak, orang dewasa yang ditempatkan di bawah pengawasan (curatele), dan orang sakit jiwa. Anak-anak adalah mereka yang belum dewasa yang menurut Undang-Undang Nomor 1 Tahun 1974 tentang Perkawinan belum berumur 18 (delapan belas) tahun. Meskipun belum berumur 18 (delapan belas) tahun, apabila seseorang telah atau pernah kawin dianggap sudah dewasa, berarti cakap untuk membuat perjanjian.

3. Hal tertentu. Maksudnya objek yang diatur kontrak harus jelas, setidak-tidaknya dapat ditentukan. Jadi, tidak boleh samarsamar. Hal ini penting untuk memberikan jaminan atau kepastian kepada pihak-pihak dan mencegah timbulnya kontrak fiktif.

2. Sebab yang dibolehkan. Maksudnya isi kontrak tidak boleh bertentangan dengan perundang-undangan yang bersifat memaksa, ketertiban umum, dan atau kesusilaan.

4. Undang-Undang Nomor 37 Tahun 1999 tentang Hubungan Luar Negeri

Dalam Pasal 8 UU Nomor 37 Tahun 1999 tentang Hubungan Luar Negeri, disebutkan bahwa "Menteri, atas usul pimpinan departemen atau lembaga pemerintah non-departemen, dapat mengangkat pejabat dari departemen atau lembaga yang bersangkutan untuk ditempatkan pada Perwakilan Republik Indonesia guna melaksanakan tugas-tugas yang 
menjadi bidang wewenang departemen atau lembaga tersebut. Pejabat dimaksud secara operasional dan administratif merupakan bagian yang tidak terpisahkan dari Perwakilan Republik Indonesia serta tunduk pada peraturan-peraturan tentang tata kerja Perwakilan Republik Indonesia di luar negeri. Ketentuan ini berkaitan dengan peran Perwakilan Republik Indonesia dalam proses penempatan dan perlindungan Pekerja Indonesia di negara tujuan penempatan.

Adapun mengenai perlindungan Pekerja Indonesia di luar negeri, Pasal 18 mengatur bahwa Pemerintah Republik Indonesia melindungi kepentingan warga negara atau badan hukum Indonesia yang menghadapi permasalahan hukum dengan perwakilan negara asing di Indonesia. Pemberian perlindungan tersebut dilakukan sesuai dengan ketentuan hukum dan kebiasaan internasional.

Sebagai bentuk kewajiban terhadap warga negaranya di luar negeri, Pasal 19 menyebutkan bahwa perwakilan Republik Indonesia berkewajiban memupuk persatuan dan kerukunan antara sesama warga negara Indonesia di luar negeri dan memberikan pengayoman, perlindungan, dan bantuan hukum bagi warga negara dan badan hukum Indonesia di luar negeri, sesuai dengan peraturan perundang-undangan nasional serta hukum dan kebiasaan internasional. Dalam hal terjadi sengketa antara sesama warga negara atau badan hukum Indonesia di luar negeri, Perwakilan Republik Indonesia berkewajiban membantu menyelesaikannya berdasarkan asas musyawarah atau sesuai dengan hukum yang berlaku (Pasal 20). 
5. Undang-Undang Nomor 39 Tahun 1999 tentang Hak Asasi Manusia

Pasal 1 angka 1 UU Nomor 39 Tahun 1999 tentang Hak Asasi Manusia menyatakan bahwa Hak Asasi Manusia adalah seperangkat hak yang melekat pada hakikat dan keberadaan manusia sebagai mahluk Tuhan Yang Maha Esa dan merupakan anugrah-Nya yang wajib dihormati, dijunjung tinggi dan dilindungi oleh Negara, hukum, pemerintahan, dan setiap orang demi kehormatan serta perlindungan harkat dan martabat manusia.

Terkait dengan hak perlindungan Pasal 3 ayat (2) yang menyatakan bahwa setiap orang berhak atas pengakuan, jaminan, perlindungan dan perlakuan hukum yang adil, serta mendapat kepastian hukum dalam semangat di depan hukum. Kemudian Pasal 3 ayat (3) dinyatakan bahwa setiap orang berhak atas perlindungan hak asasi manusia dan kebebasan manusia, tanpa diskriminasi.

Selanjutnya dalam Pasal 5 diatur bahwa "setiap orang diakui sebagai manusia pribadi yang berhak menuntut dan memperoleh perlakuan serta perlindungan yang sama sesuai dengan martabat kemanusiaanya di depan hukum dan setiap orang berhak mendapat bantuan dan perlindungan yang adil dari pengadilan yang objektif dan tidak berpihak (ayat (1) dan (2)).

Sedangkan pada ayat (3) disebutkan bahwa "setiap orang yang termasuk kelompok masyarakat yang rentan berhak memperoleh perlakuan dan perlindungan lebih berkenaan dengan kekhususannya." Dalam Pasal 8 dijelaskan bahwa perlindungan, pemajuan, penegakan, 
dan pemenuhan hak asasi manusia terutama menjadi tanggung jawab Pemerintah. Selanjutnya dalam penjelasannya dinyatakan bahwa yang dimaksud dengan "perlindungan" adalah termasuk pembelaan hak asasi manusia.

Pasal 12 menerangkan bahwa "setiap orang berhak atas perlindungan bagi pengembangan pribadinya, untuk memperoleh pendidikan, mencerdaskan dirinya, dan meningkatkan kualitas hidupnya agar menjadi manusia yang beriman, bertaqwa, bertanggung jawab, berakhlak mulia, bahagia, dan sejahtera sesuai dengan hak asasi manusia." Adapun hak berkomunikasi dan memperoleh informasi diatur dalam Pasal 14 ayat (1) yang menyatakan bahwa "setiap orang berhak untuk berkomunikasi dan memperoleh informasi yang diperlukan untuk mengembangkan pribadi dan lingkungan sosialnya."

Pemenuhan hak-hak dasar lainnya juga diatur dalam Pasal 28, Pasal 30 dan 38. Dalam Pasal 28 ayat (1) menyatakan bahwa setiap orang berhak mencari suaka untuk memperoleh perlindungan politik dari negara lain. Pasal 29 ayat 1 menyatakan bahwa "setiap orang berhak atas perlindungan diri pribadi, keluarga, kehormatan, martabat, dan hak miliknya". Pasal 30 menyatakan bahwa "setiap orang berhak atas rasa aman dan tenteram serta perlindungan terhadap ancaman ketakutan untuk berbuat atau tidak berbuat sesuatu". Kebebasan memilih suatu pekerjaan diatur dalam Pasal 38 ayat (2) yang menyebutkan bahwa "setiap orang bebas memilih pekerjaan yang disukainya dan berhak pula atas syarat-syarat ketenagakerjaan". 
Terkait dengan perlindungan bagi Pekerja Indonesia wanita, Pasal 49 dalam ayat 2 dan 3 menjelaskan bahwa wanita berhak untuk mendapatkan perlindungan khusus dalam pelaksanaan pekerjaan atau profesinya terhadap hal-hal yang dapat mengancam keselamatan dan atau kesehatannya berkenaan dengan fungsi reproduksi wanita. Hak khusus yang melekat pada diri wanita dikarenakan fungsi reproduksinya, dijamin, dan dilindungi oleh hukum. Selanjutnya dalam penjelasan Pasal 49 Ayat (2) dijelaskan bahwa yang dimaksud dengan "perlindungan khusus terhadap fungsi reproduksi" adalah pelayanan kesehatan yang berkaitan dengan haid, hamil, melahirkan, dan pemberian kesempatan untuk menyusui anak.

6. Undang-Undang Nomor 21 Tahun 2000 tentang Serikat Pekerja

Pasal 1 angka 1 menyebutkan serikat pekerja/serikat buruh adalah organisasi yang dibentuk dari, oleh, dan untuk pekerja/buruh baik di perusahaan maupun di luar perusahaan, yang bersifat bebas, terbuka, mandiri, demokratis, dan bertanggung jawab guna memperjuangkan, membela serta melindungi hak dan kepentingan pekerja/buruh serta meningkatkan kesejahteraan pekerja/buruh dan keluarganya. Serikat pekerja/serikat buruh di perusahaan adalah serikat pekerja/serikat buruh yang didirikan oleh para pekerja/buruh di satu perusahaan atau di beberapa perusahaan (Pasal 1 angka 2). Adapun serikat pekerja/serikat buruh di luar perusahaan adalah serikat pekerja/serikat buruh yang didirikan oleh para pekerja/serikat yang tidak bekerja di perusahaan.

Dalam Pasal 5, disebutkan setiap pekerja/buruh berhak 
membentuk dan menjadi anggota serikat pekerja/serikat buruh. Serikat pekerja/serikat buruh dibentuk oleh sekurang-kurangnya 10 (sepuluh) orang pekerja/buruh. Sedangkan dalam Pasal 6, serikat pekerja/serikat buruh berhak membentuk dan menjadi anggota federasi serikat pekerja/serikat buruh. Federasi serikat pekerja/serikat buruh dibentuk oleh sekurang-kurangnya 5 (lima) serikat pekerja/serikat buruh.

Adapun dalam perlindungan hak berorganisasi (Pasal 28), Siapapun dilarang menghalang-halangi atau memaksa pekerja/buruh untuk membentuk atau tidak membentuk, menjadi pengurus atau tidak menjadi pengurus, menjadi anggota atau tidak menjadi anggota dan/atau menjalankn atau tidak menjalankan kegiatan serikat pekerja/serikat buruh dengan cara :

a. melakukan pemutusan hubungan kerja, memberhentikan sementara, menurunkan jabatan, atau melakukan mutasi;

b. tidak membayar atau mengurangi upah pekerja/buruh;

c. melakukan intimidasi dalam bentuk apapun;

d. melakukan kampanye anti pembentukan serikat pekerja/serikat buruh.

7. Undang-Undang Nomor 13 Tahun 2003 tentang Ketenagakerjaan

Pekerja adalah setiap orang yang melakukan pekerjaan, baik dalam hubungan kerja maupun diluar hubungan kerja.41 Pekerja merupakan subyek hokum yang perlu dilindungi dalam suatu aturan tertulis. Sebelum lahirnya UU Nomor 13 Tahun 2003, secara yuridis peraturan perundang-undangan yang menjadi dasar acuan penempatan 
dan perlindungan pekerja Indonesia di luar negeri adalah Ordonansi tentang Pengerahan Orang Indonesia Untuk Melakukan Pekerjaan di Luar Indonesia (Staatsblad Tahun 1887 Nomor 8) dan Keputusan Menteri serta peraturan pelaksanaannya.

Diundangkannya UU Nomor 13 Tahun 2003 tentang Ketenagakerjaan, Ordonansi tentang Pengerahan Orang Indonesia Untuk Melakukan Pekerjaan Di Luar Negeri dinyatakan tidak berlaku lagi dan diamanatkan penempatan tenaga kerja ke luar negeri diatur dalam undang-undang tersendiri. Pengaturan melalui undang-undang tersendiri, diharapkan mampu merumuskan norma-norma hukum yang melindungi pekerja Indonesia di luar negeri dari berbagai upaya dan perlakuan eksploitatif dari siapapun.

Undang-undang Nomor 13 Tahun 2003 tentang Ketenagakerjaan yang merupakan induk dari UU Nomor 39 Tahun 2004 tentang penempatan dan perlindungan tenaga kerja Indonesia di Luar negeri memberikan pengertian pada Pasal 1 angka 3 bahwa pekerja adalah setiap orang yang bekerja dengan menerima upah atau imbalan dalam bentuk lain. UU Nomor 13 Tahun 2003 tentang Ketenagakerjaan juga mengatur tentang pihak-pihak yang terlibat dalam UU Nomor 39 Tahun 2004 tentang Penempatan dan Perlindungan Tenaga Kerja di Luar Negeri seperti hubungan kerja, majikan, pelatihan kerja, hingga kompetensi kerja, yang masuk kedalam bab tentang ketentuan umum.

Pasal 5 UU Nomor 13 Tahun 2003 tentang Ketenagakerjaan meyebutkan bahwa setiap tenaga kerja memiliki kesempatan yang sama 
tanpa diskriminasi untuk memperoleh pekerjaan. Oleh karena itu pekerja Indoneis yang mencari pekerjaan di Luar negeri tidak dapat dicegah bahwa seharusnya pemerintah mendukung hal tersebut. Setiap pekerja Indonesia yang akan ke luar negeri berhak untuk mengikuti pelatihan kerja seperti ayng tertuang dalam Bab V tentang Pelatihan Kerja UU Nomor 13 Tahun 2003 tentang Ketenagakerjaan. Perbedaannya adalah ketika UU Nomor 13 Tahun 2003 tentang Ketenagakerjaan mengatur tentang pelatihan kerja dengan cara magang, sedangkan UU no 39 tahun 2004 mengaturnya dengan cara pelatihan di Balai Latihan Kerja.

Pasal 31 menyebutkan bahwa llsetiap tenaga kerja mempunyai hak dan kesempatan yang sama untuk memilih, mendapatkan, atau pindah pekerjaan dan memperoleh penghasilan yang layak di dalam atau di luar negeri.ll Penempatan tenaga kerja harus dilaksanakan berdasarkan asas terbuka, bebas, obyektif, serta adil, dan setara tanpa diskriminasi (Pasal 32 ayat (1)). Seharusnya asas-asas ini pulalah yang menjadi dasar dalam pengaturan penempatan Pekerja Indonesia di luar negeri. Penempatan pekerja diarahkan untuk menempatkan pekerja pada jabatan yang tepat sesuai dengan keahlian, keterampilan, bakat, minat, dan kemampuan dengan memperhatikan harkat, martabat, hak asasi, dan perlindungan hukum (Pasal 32 ayat (2)). Tepatnya dalam Pasal 34, ketentuan mengenai pendelegasian pembentukan undang-undang yang mengatur penempatan Pekerja Indonesia di luar negeri. Pasal 34 menyebutkan: "Ketentuan mengenai penempatan tenaga kerja di luar negeri sebagaimana dimaksud dalam Pasal 33 huruf $b$ diatur dengan undang-undang". 
UU Ketenagakerjaan telah diatur bahwa Pelaksana Penempatan kerja wajib memberikan perlindungan sejak rekrutmen sampai penempatan tenaga kerja (Pasal 35 ayat (2)). Sedangkan bagi pemberi kerja dalam mempekerjakan tenaga kerja wajib memberikan perlindungan yang mencakup kesejahteraan, keselamatan, dan kesehatan baik fisik maupun mental tenaga kerja (Pasal 35 ayat (3)).

Pengaturan penempatan tenaga kerja diharapkan memberikan pelayanan yang bersifat terpadu dalam satu sistem penempatan tenaga kerja yang meliputi unsur-unsur (Pasal 36):

a. pencari kerja;

b. lowongan pekerjaan;

c. informasi pasar kerja;

d. mekanisme antar kerja; dan

e. kelembagaan penempatan tenaga kerja.

Adapun terkait kelembagaan, dalam Pasal 37 disebutkan bahwa pelaksana penempatan tenaga kerja terdiri dari: (a) instansi pemerintah yang bertanggung jawab di bidang ketenagakerjaan; dan (b) lembaga swasta berbadan hukum.

8. Undang-Undang Nomor 23 Tahun 2004 tentang Penghapusan Kekerasan dalam Rumah Tangga

Jumlah pekerja Indonesia di luar negeri khususnya yang bekerja pada sektor domestik, banyak mengalami kekerasan dalam rumah tangga. Dalam UU Nomor 23 Tahun 2004 ini dalam Pasal 1 angka 1 dinyatakan bahwa Kekerasan dalam Rumah Tangga adalah setiap perbuatan terhadap seseorang terutama perempuan, yang berakibat 
timbulnya kesengsaraan atau penderitaan secara fisik, seksual, psikologis, dan/atau penelantaran rumah tangga termasuk ancaman untuk melakukan perbuatan, pemaksaan, atau perampasan kemerdekaan secara melawan hukum dalam lingkup rumah tangga. Selanjutnya dalam Pasal 2 disebutkan bahwa, lingkup rumah tangga dalam UU Nomor 23 Tahun 2004 ini meliputi: (a) suami, isteri, dan anak; (b) orang-orang yang mempunyai hubungan keluarga dengan orang sebagaimana dimaksud pada huruf a karena hubungan darah, perkawinan, persusuan, pengasuhan, dan perwalian, yang menetap dalam rumah tangga; dan/atau dan (c) orang yang bekerja membantu rumah tangga dan menetap dalam rumah tangga tersebut.

Pada Pasal 5 disebutkan bahwa setiap orang dilarang melakukan kekerasan dalam rumah tangga terhadap orang dalam lingkup rumah tangganya, dengan cara:

1) kekerasan fisik yaitu perbuatan yang mengakibatkan rasa sakit, jatuh sakit, atau luka berat;

2) kekerasan psikis yaitu perbuatan yang mengakibatkan ketakutan, hilangnya rasa percaya diri, hilangnya kemampuan untuk bertindak, rasa tidak berdaya, dan/atau penderitaan psikis berat pada seseorang;

3) kekerasan seksual meliputi pemaksaan hubungan seksual yang dilakukan terhadap orang yang menetap dalam lingkup rumah tangga tersebut dan pemaksaan hubungan seksual terhadap 
salah seorang dalam lingkup rumah tangganya dengan orang lain untuk tujuan komersial dan/atau tujuan tertentu, atau

4) penelantaran rumah tangga.

Pasal 10 menyebutkan bahwa korban kekerasan dalam rumah tangga berhak mendapatkan:

a. perlindungan dari pihak keluarga, kepolisian, kejaksaan, pengadilan, advokat, lembaga sosial, atau pihak lainnya baik sementara maupun berdasarkan penetapan perintah perlindungan dari pengadilan;

b. pelayanan kesehatan sesuai dengan kebutuhan medis;

c. penanganan secara khusus berkaitan dengan kerahasiaan korban;

d. pendampingan oleh pekerja sosial dan bantuan hukum pada setiap tingkat proses pemeriksaan sesuai dengan ketentuan peraturan perundang-undangan; dan

e. pelayanan bimbingan rohani.

Selain itu, dalam Pasal 39 disebutkan juga bahwa untuk kepentingan pemulihan, korban dapat memperoleh pelayanan dari tenaga kesehatan, pekerja sosial, relawan pendamping, dan/atau pembimbing rohani.

9. Undang-Undang Nomor 40 Tahun 2004 tentang Sistem Jaminan Sosial Nasional

Dalam Undang-Undang ini pengertian jaminan sosial adalah salah satu bentuk perlindungan sosial untuk menjamin seluruh rakyat agar dapat 
memenuhi kebutuhan dasar hidupnya yang layak (Pasal 1 angka 1). Adapun Sistem Jaminan Sosial Nasional adalah suatu tata cara penyelenggaraan program jaminan sosial oleh beberapa badan penyelenggara jaminan sosial (Pasal 1 angka 2). Adapun Asuransi sosial adalah suatu mekanisme pengumpulan dana yang bersifat wajib yang berasal dari iuran guna memberikan perlindungan atas risiko sosial ekonomi yang menimpa peserta dan/atau anggota keluarganya (Pasal 1 angka 3). Badan Penyelenggara Jaminan Sosial adalah badan hukum yang dibentuk untuk menyelenggarakan program jaminan sosial (Pasal 1 angka 7).

Dana Jaminan Sosial sebagai dana amanat milik seluruh peserta yang merupakan himpunan iuran beserta hasil pengembangannya yang dikelola oleh Badan Penyelenggara Jaminan Sosial untuk pembayaran manfaat kepada peserta dan pembiayaan operasional penyelenggaraan program jaminan sosial. Berdasarkan Pasal 5, Badan Penyelenggara Jaminan Sosial harus dibentuk dengan Undang-Undang. Adapun sejak berlakunya Undang-Undang ini, badan penyelenggara jaminan sosial yang ada dinyatakan sebagai Badan Penyelenggara Jaminan Sosial menurut Undang-Undang ini. Badan Penyelenggara Jaminan Sosial dimaksud adalah:

a. Perusahaan Perseroan (Persero) Jaminan Sosial Tenaga Kerja (JAMSOSTEK);

b. Perusahaan Perseroan (Persero) Dana Tabungan dan Asuransi Pegawai Negeri (TASPEN); 
c. Perusahaan Perseroan (Persero) Asuransi Sosial Angkatan Bersenjata Republik Indonesia (ASABRI); dan

d. Perusahaan Perseroan (Persero) Asuransi Kesehatan Indonesia (ASKES).

Dalam hal diperlukan Badan Penyelenggara Jaminan Sosial selain keempat perusahaan tersebut dapat dibentuk yang baru dengan UndangUndang.

Untuk penyelenggaraan Sistem Jaminan Sosial Nasional dengan Undang-Undang ini dibentuk Dewan Jaminan Sosial Nasional (Pasal 6). Dewan Jaminan Sosial Nasional bertanggung jawab kepada Presiden, dan berfungsi merumuskan kebijakan umum dan sinkronisasi penyelenggaraan Sistem Jaminan Sosial Nasional.

Pengaturan kepesertaan dalam system jaminan sosial sebagai berikut:

a. Pemberi kerja secara bertahap wajib mendaftarkan dirinya dan pekerjanya sebagai peserta kepada Badan Penyelenggara Jaminan Sosial, sesuai dengan program jaminan sosial yang diikuti (Pasal 13).

b. Pemerintah secara bertahap mendaftarkan penerima bantuan iuran sebagai peserta kepada Badan Penyelenggara Jaminan Sosial. Penerima bantuan iuran dimaksud adalah fakir miskin dan orang tidak mampu (Pasal 14).

Adapun jenis Program Jaminan Sosial meliputi (Pasal 18):

a. jaminan kesehatan; 
Jaminan kesehatan diselenggarakan secara nasional berdasarkan prinsip asuransi sosial dan prinsip ekuitas yang diselenggarakan dengan tujuan menjamin agar peserta memperoleh manfaat pemeliharaan kesehatan dan perlindungan dalam memenuhi kebutuhan dasar kesehatan (Pasal 19). Peserta jaminan kesehatan adalah setiap orang yang telah membayar iuran atau iurannya dibayar oleh Pemerintah. Anggota keluarga peserta berhak menerima manfaat jaminan kesehatan. Setiap peserta dapat mengikutsertakan anggota keluarga yang lain yang menjadi tanggungannya dengan penambahan iuran (Pasal 20).

b. jaminan kecelakaan kerja;

Jaminan kecelakaan kerja diselenggarakan secara nasional berdasarkan prinsip asuransi sosial dan diselenggarakan dengan tujuan menjamin agar peserta memperoleh manfaat pelayanan kesehatan dan santunan uang tunai apabila seorang pekerja mengalami kecelakaan kerja atau menderita penyakit akibat kerja (Pasal 29). Peserta jaminan kecelakaan kerja adalah seseorang yang telah membayar iuran (Pasal 30).

c. jaminan hari tua;

Jaminan hari tua diselenggarakan secara nasional berdasarkan prinsip asuransi sosial atau tabungan wajib dan diselenggarakan dengan tujuan untuk menjamin agar peserta menerima uang tunai apabila memasuki masa pensiun, 
mengalami cacat total tetap, atau meninggal dunia (Pasal 35). Peserta jaminan hari tua adalah peserta yang telah membayar iuran (Pasal 36).

d. jaminan pensiun;

Jaminan pensiun diselenggarakan secara nasional berdasarkan prinsip asuransi sosial atau tabungan wajib untuk mempertahankan derajat kehidupan yang layak pada saat peserta kehilangan atau berkurang penghasilannya karena memasuki usia pensiun atau mengalami cacat total tetap. Jaminan pensiun diselenggarakan berdasarkan manfaat pasti.

Usia pensiun ditetapkan menurut ketentuan peraturan perundang-undangan (Pasal 39).

e. jaminan kematian.

Jaminan kematian diselenggarakan secara nasional berdasarkan prinsip asuransi sosial dengan tujuan untuk memberikan santunan kematian yang dibayarkan kepada ahli waris peserta yang meninggal dunia.

Pengaturan mengenai pengelolaan dana jaminan sosial wajib dikelola dan dikembangkan oleh Badan Penyelenggara Jaminan Sosial secara optimal dengan mempertimbangkan aspek likuiditas, solvabilitas, kehati-hatian, keamanan dana, dan hasil yang memadai. Pemerintah dapat melakukan tindakan-tindakan khusus guna menjamin terpeliharanya tingkat kesehatan keuangan Badan Penyelenggara Jaminan Sosial (Pasal 40). 
10. Undang-Undang Nomor 21 Tahun 2007 tentang Pemberantasan Tindak Pidana Perdagangan Orang

Para Pekerja Indonesia di Luar Negeri terutama mereka yang tidak berdokumen sangat rentan menjadi korban tindak pidana perdagangan orang. Dalam hal ditemukan indikasi tindak pidana perdagangan orang dalam proses pemberangkatan dan penempatan tenaga kerja, maka petugas yang berwenang dapat melakukan tindakan pencegahan agar tidak sampai terjadi perdagangan orang tersebut.

Menurut UU Nomor 21 Tahun 2007, Pasal 1 angka 1 perdagangan orang adalah tindakan perekrutan, pengangkutan, penampungan, pengiriman, pemindahan, atau penerimaan seseorang dengan ancaman kekerasan, penggunaan kekerasan, penculikan, penyekapan, pemalsuan, penipuan dan penyalahgunaan kekuasaan atau posisi rentan, penjeratan uang atau memberikan bayaran atau manfaat, sehingga memperoleh persetujuan dari orang yang memegang kendali atas orang lain tersebut, baik yang dilakukan di dalam negara maupun antar negara, untuk tujuan ekspolitasi atau mengakibatkan orang tereksploitasi.

Yang dimaksud dengan eksploitasi adalah tindakan dengan atau tanpa persetujuan korban yang meliputi semua tindakan eksploitasi yang tidak terbatas pada pelacuran, kerja atau pelayanan paksa, perbudakan atau praktik serupa perbudakan, penindasan, pemerasan, pemanfaatan fisik, seksual, organ reproduksi, atau melawan hukum memindahkan atau mentransplantasi organ dan/atau jaringan tubuh atau memanfaatkan tenaga atau kemampuan seseorang oleh pihak lain untuk mendapatkan keuntungan baik materiil maupun immateriil (Pasal 1 angka 7). 
Modus operandi yang digunakanpun terkesan mirip dengan pencarian tenaga kerja untuk ditempatkan diluar negeri. Tindakan perekrutan yang dilakukan dalam rangka perdagangan orang tersebut meliputi mengajak, mengumpulkan, membawa, atau memisahkan seseorang dari keluarga atau komunitasnya (Pasal 1 angka 9). Ciri khas tindak pidana ini antara lain mengandung unsur kekerasan yang tidak hanya bersifat fisik, tetapi juga psikis dan adanya ancaman kekerasan. Pasal 1 angka 11 dijelaskan bahwa kekerasan adalah setiap perbuatan secara melawan hukum, dengan atau tanpa menggunakan sarana terhadap fisik dan psikis yang menimbulkan bahaya bagi nyawa, badan, atau menimbulkan terampasnya kemerdekaan seseorang. Pasal 1 angka 12 dinyatakan bahwa ancaman kekerasan adalah setiap perbuatan secara melawan hukum berupa ucapan, tulisan, gambar, simbol, atau gerakan tubuh, baik dengan atau tanpa menggunakan sarana yang menimbulkan rasa takut atau mengekang kebebasan hakiki seseorang.

UU ini telah mengatur besarnya pidana bagi orang yang melakukan tindak pidana perdagangan orang. Dalam Pasal 2 ayat (1) diatur bahwa setiap orang yang melakukan perekrutan, pengangkutan, penampungan, pengiriman, pemindahan, atau penerimaan seseorang dengan ancaman kekerasan, penggunaan kekerasan, penculikan, penyekapan, pemalsuan, penipuan, penyalahgunaan kekuasaan atau posisi rentan, penjeratan utang, atau memberi bayaran atau manfaat walaupun memperoleh persetuujuan dari orang yang memegang kendali atas orang lain, untuk tujuan mengeksploitasi orang tersebut di wilayah negara Republik 
Indonesia, dipidana dengan pidana penjara paling singkat 3 (tiga) tahun dan paling lama 15 (lima belas) tahun dan pidana denda paling sedikit Rp. 120.000.000,-(Seratus dua puluh juta rupiah) dan paling banyak Rp. 600.000.000,-(Enam ratus juta rupiah).

Sedangkan dalam Pasal 4 dinyatakan bahwa setiap orang yang membawa warga negara Indonesia ke luar wilayah negara Republik Indonesia dengan maksud untuk dieksploitasi di luar wilayah negara Republik Indonesia dipidana dengan pidana penjara paling singkat 3 (tiga) tahun dan paling lama 15 (lima belas) tahun dan pidana denda paling sedikit Rp. 120.000.000,- (Seratus dua puluh juta rupiah) dan paling banyak Rp. 600.000.000,- (Enam ratus juta rupiah).

Dalam Pasal 16 diberlakukan pemberatan hukuman dalam hal tindak pidana perdagangan orang dilakukan oleh kelompok yang terorganisasi. Setiap pelaku tindak pidana perdagangan orang dalam kelompok yang terorganisasi tersebut dipidana dengan pidana yang sama sebagaimana dimaksud dalam Pasal 2 ditambah 1/3 (sepertiga). Demikian pula jika perdagangan orang tersebut dilakukan terhadap anak, maka ancaman pidananya ditambah 1/3 (sepertiga) (Pasal 17).

UU ini juga mengatur beberapa tindak pidana lain yang berkaitan dengan tindak pidana perdagangan orang dengan masing-masing hukumannya. Tindakan pidana yang berkaitan antara lain seperti orang yang memberikan atau memasukkan keterangan palsu pada dokumen negara atau dokumen lain, atau memalsukan dokumen negara atau 
dokumen lain, untuk mempermudah terjadinya tindak pidana perdagangan orang (Pasal 19).

Begitu juga dengan orang yang memberikan kesaksian palsu, menyampaikan alat bukti palsu atau barang bukti palsu, atau mempengaruhi saksi secara melawan hukum di sidang pengadilan tindak pidana perdagangan orang (Pasal 20), orang yang melakukan penyerangan fisik terhadap saksi atau petugas di persidangan dalam perkara tindak pidana perdagangan orang (Pasal 21), orang yang dengan sengaja mencegah, merintangi, atau menggagalkan secara langsung atau tidak langsung penyidikan, penuntutan, dan pemeriksaan di sidang pengadilan terhadap tersangka, terdakwa, atau saksi dalam perkara perdagangan orang (Pasal 22), dan orang yang membantu pelarian pelaku tindak pidana perdagangan orang dari proses peradilan pidana (Pasal 23), serta orang yang memberitahukan identitas saksi atau korban padahal kepadanya telah diberitahukan, bahwa identitas saksi atau korban tersebut harus dirahasiakan (Pasal 24).

11. Undang-Undang Nomor 11 Tahun 2009 tentang Kesejahteraan Sosial Beberapa ketentuan dalam Undang-Undang Nomor 11 Tahun 2009 berkaitan dengan perlindungan dan penempatan pekerja Indonesia di luar negeri antara lain mengenai perlindungan sosial. Pasal 1 angka 9 dinyatakan bahwa perlindungan sosial adalah semua upaya yang diarahkan untuk mencegah dan menangani risiko dari guncangan dan kerentanan sosial. Dalam Pasal 14 diatur bahwa perlindungan sosial dimaksudkan untuk mencegah dan menangani risiko dari guncangan dan 
kerentanan sosial seseorang, keluarga, kelompok, dan/atau masyarakat agar kelangsungan hidupnya dapat dipenuhi sesuai dengan kebutuhan dasar minimal. Perlindungan sosial tersebut dilaksanakan melalui: (a) bantuan sosial; (b) advokasi sosial; dan/atau (c) bantuan hukum.

Adapun perlindungan sosial dalam bentuk bantuan sosial dimaksudkan agar seseorang, keluarga, kelompok, dan/atau masyarakat yang mengalami guncangan dan kerentanan sosial dapat tetap hidup secara wajar. Bantuan sosial ini bersifat sementara dan/atau berkelanjutan dalam bentuk: a. bantuan langsung; b. penyediaan aksesibilitas; dan/atau c. penguatan kelembagaan (Pasal 15).

Sementara advokasi sosial dimaksudkan untuk melindungi dan membela seseorang, keluarga, kelompok, dan/atau masyarakat yang dilanggar haknya. Advokasi sosial diberikan dalam bentuk penyadaran hak dan kewajiban, pembelaan, dan pemenuhan hak (Pasal 16). Sedangkan bantuan hukum diselenggarakan untuk mewakili kepentingan warga negara yang menghadapi masalah hukum dalam pembelaan atas hak, baik di dalam maupun di luar pengadilan. Bantuan hukum diberikan dalam bentuk pembelaan dan konsultasi hukum (Pasal 17).

Dalam hal ini TKI di Luar Negeri yang mengalami masalah dan membutuhkan perlindungan (sosial) berhak mendapatkan perlindungan tersebut dengan bentuk perlindungan yang disesuaikan pada kasus dan kebutuhan Pekerja Indonesia di Luar Negeri yang bersangkutan.

12. Undang-Undang Nomor 6 Tahun 2011 tentang Keimigrasian 
Persyaratan dokumen yang harus dimilki oleh calon pekerja Indonesia untuk dapat ditempatkan ke luar negeri yaitu paspor. Paspor diterbitkan setelah mendapat rekomendasi dari dinas yang bertanggung jawab di bidang ketenagakerjaan di kabupaten/kota setempat. Pasal 1 angka 15 menyebutkan Dokumen Perjalanan Republik Indonesia adalah Paspor Republik Indonesia dan Surat Perjalanan Laksana Paspor Republik Indonesia. Paspor didefinisikan dalam Pasal 1 angka 16 adalah dokumen yang dikeluarkan oleh Pemerintah Republik Indonesia kepada warga negara Indonesia untuk melakukan perjalanan antarnegara yang berlaku selama jangka waktu tertentu.

Dalam keadaan khusus apabila tidak dapat diberikan, sebagai penggantinya dikeluarkan dokumen perjalanan Republik Indonesia lainnya yaitu Surat Perjalanan Laksana Paspor Republik Indonesia yang selanjutnya disebut Surat Perjalanan Laksana Paspor adalah dokumen pengganti paspor yang diberikan dalam keadaan tertentu yang berlaku selama jangka waktu tertentu (Pasal 1 angka 17).

Setiap Pekerja Indonesia yang masuk atau keluar Wilayah Indonesia wajib memiliki Dokumen Perjalanan yang sah dan masih berlaku (Pasal 8 ayat 1). Selain itu Pekerja Indonesia dapat masuk atau keluar Wilayah Indonesia dan wajib melalui pemeriksaan yang dilakukan oleh Pejabat Imigrasi di Tempat Pemeriksaan Imigrasi (Pasal 9 ayat (1)).

Pekerja Indonesia wajib memiliki paspor biasa, mengingat jenis surat perjalanan yang dipergunakan adalah paspor biasa diperuntukkan bagi Warga Negara Indonesia (Pasal 26 ayat (1)). 
13. Undang-Undang Nomor 24 Tahun 2011 tentang Badan Penyelenggara Jaminan Sosial

Perlindungan bagi Pekerja Indonesia dalam bentuk jaminan santunan dulunya diatur dalam UU Nomor 3 Tahun 1992 tentang Jaminan Sosial Tenaga Kerja. Sebagai Lembaga Negara yang bergerak dalam bidang asuransi sosial dahulu bernama PT. Jamsostek (Persero) diganti dengan BPJS Ketenagakerjaan yang merupakan pelaksana undangundang jaminan sosial tenaga kerja.

Badan Penyelenggara Jaminan Sosial Ketenagakerjaan (BPJS Ketenagakerjaan) merupakan program publik yang memberikan perlindungan bagi tenaga kerja untuk mengatasi risiko sosial ekonomi tertentu dan penyelenggaraannya menggunakan mekanisme asuransi sosial.

Pasal 1 UU Nomor 24 Tahun 2011 mendefinisikan Badan Penyelenggara Jaminan Sosial yang selanjutnya disingkat BPJS adalah badan hukum yang dibentuk untuk menyelenggarakan program jaminan sosial.

Berdasarkan Pasal 5, bentuk BPJS ada dua yaitu BPJS Kesehatan dan BPJS Ketenagakerjaan. Pasal 6 ayat (1) menjelaskan bahwa BPJS Kesehatan ruang lingkupnya program jaminan kesehatan, sedangkan BPJS Ketenagakerjaan ruang lingkupnya meliputi : a. jaminan kecelakaan; b. jaminan hari tua; c. jaminan pensiun; dan d. jaminan kematian.

Setiap orang baik Pekerja Indonesia maupun orang asing yang bekerja paling singkat 6 (enam) bulan di Indonesia, wajib menjadi Peserta program Jaminan Sosial. Ketentuan pendaftaran kepesertaan tersebut 
dapat dilihat dalam Pasal 14. Pemberi Kerja secara bertahap wajib mendaftarkan dirinya dan Pekerjanya sebagai Peserta kepada BPJS sesuai dengan program Jaminan Sosial yang diikuti (Pasal 15 ayat (1)).

14. Undang Undang Nomor 31 Tahun 2014 tentang Perlindungan Saksi dan Korban

Perlakuan tidak menyenangkan yang dialami dan diterima oleh sejumlah Pekerja Indonesia di Luar negeri menjadikan Pekerja Indonesia tersebut memiliki status saksi dan korban dari berbagai kasus kekerasan, penyiksaan, dan perdagangan orang. Menjadi Saksi atau korban dalam sebuah kasus yang diproses melalui proses peradilan kemudian membahayakan jiwa dan raga dari ancaman hingga kekerasan yang diterima. Oleh karena itu, Pekerja Indonesia di luar negeri yang mengalami permasalahan sampai di tingkat peradilan harus dilindungi. Pasal 2 Undang-Undang Republik Indonesia Nomor 31 Tahun 2014 tentang Saksi dan Korban disebutkan bahwa Undang- Undang ini memberikan perlindungan pada Saksi dan Korban dalam semua tahap proses peradilan pidana dalam lingkungan peradilan. Perlindungan Saksi dan Korban bertujuan memberikan rasa aman kepada Saksi dan/atau Korban dalam memberikan keterangan pada setiap proses peradilan pidana.

Sesuai dengan Pasal 1 angka 1 dan angka 3, Pekerja Indonesia yang mengalami kerugian fisik, mental, dan atau kerugian ekonomi yang diakibatkan oleh kejadian pidana seperti penipuan majikan yang tidak membayarkan gaji hingga calo yang membawa kabur uang pekerja Indonesia memenuhi rumusan bahwa pekerja Indonesia dapat dikatakasn 
sebagai korban. Pekerja Indonesia yang dapat memberikan keterangan untuk kepentingan penyelidikan atas kasus penipuan atau perdagangan orang pengadilan atas kejadian yang dialami, diketahui, dan dilihat perlu dilindungi dari rasa bahaya dan ancaman yang mengganggu saksi tersebut. Sebagai subyek yang masuk dalam kategori saksi dan korban, pekerja Indonesia juga memiliki hak dan kewajibannya yang diatur dalam Undang-Undang Republik Indonesia Nomor 31 Tahun 2014 tentang Saksi dan Korban. Selanjutnya dalam Pasal 5 ayat (1) disebutkan bahwa seorang Saksi dan Korban berhak:

a) memperoleh perlindungan atas keamanan pribadi, Keluarga, dan harta bendanya, serta bebas dari Ancaman yang berkenaan dengan kesaksian yang akan, sedang, atau telah diberikannya;

b) ikut serta dalam proses memilih dan menentukan bentuk perlindungan dan dukungan keamanan;

c) memberikan keterangan tanpa tekanan;

d) mendapat penerjemah;

e) bebas dari pertanyaan yang menjerat;

f) mendapat informasi mengenai perkembangan kasus;

g) mendapat informasi mengenai putusan pengadilan;

h) mendapat informasi dalam hal terpidana dibebaskan;

i) dirahasiakan identitasnya;

j) mendapat identitas baru;

k) mendapat tempat kediaman sementara; 
I) mendapat tempat kediaman baru;

m) memperoleh penggantian biaya transportasi sesuai dengan kebutuhan;

n) mendapat nasihat hukum;

o) memperoleh bantuan biaya hidup sementara sampai batas waktu Perlindungan berakhir; dan/atau

p) mendapat pendampingan.

Selanjutnya Pasal 6 menjelaskan hak lain yang diberikan umtuk korban pelanggaran hak asasi manusia yang berat, Korban tindak pidana terorisme,Korban tindak pidana perdagangan orang, Korban tindak pidana penyiksaan, Korban tindak pidana kekerasan seksual, dan Korban penganiayaan berat, selain berhak sebagaimana dimaksud dalam Pasal 5, juga berhak mendapatkan: (a) bantuan medis; dan (b) bantuan rehabilitasi psikososial dan psikologis.

Perlindungan dan hak-hak lain kepada Saksi dan/atau Korban dibentuk suatu lembaga yang mandiri yang bertanggung jawab kepada Presiden yaitu Lembaga Perlindungan Saksi dan Korban, yang selanjutnya disingkat LPSK. Pasal 7 menyatakan bahwa Korban melalui LPSK berhak mengajukan ke pengadilan berupa: (a) hak atas kompensasi dalam kasus pelanggaran hak asasi manusia yang berat yang diajukan oleh korban, keluarga, atau kuasanya ke pengailan melalui LPSK; dan (b) hak atas restitusi atau ganti kerugian yang menjadi tanggung jawab pelaku tindak pidana yang dapat diajukan baik sesudah atau sebelum 
putusan pengadilan yang telah memperoleh kekuatan hukum tetap melalui LPSK.

15. Undang-Undang Nomor 40 Tahun 2014 tentang Perasuransian

Materi dalam UU Nomor 40 Tahun 2014 tentang Perasuransian yang ada kaitannya dengan pembentukan RUU PPILN ialah dalam hal asurasi. Dalam Pasal 1 angka 1 UU Nomor 40 Tahun 2014 mendefinisikan asuransi adalah perjanjian antara dua pihak, yaitu perusahaan asuransi dan pemegang polis, yang menjadi dasar bagi penerimaan premi oleh perusahaan asuransi sebagai imbalan untuk:

a) memberikan penggantian kepada tertanggung atau pemegang polis karena kerugian, kerusakan, biaya yang timbul, kehilangan keuntungan, atau tanggung jawab hukum kepada pihak ketiga yang mungkin diderita tertanggung atau pemegang polis karena terjadinya suatu peristiwa yang tidak pasti; atau

b) memberikan pembayaran yang didasarkan pada meninggalnya tertanggung atau pembayaran yang didasarkan pada hidupnya tertanggung dengan manfaat yang besarnya telah ditetapkan dan/atau didasarkan pada hasil pengelolaan dana (Pasal 1 Angka 1).

Adapun obyek Asuransi dalam UU Nomor 40 Tahun 2014 adalah jiwa dan raga, kesehatan manusia, tanggung jawab hukum, benda dan jasa, serta semua kepentingan lainnya yang dapat hilang, rusak, rugi, dan/ atau berkurang nilainya (Pasal 1 angka 25). 
Di dalam UU ini kaitannya dengan perlindungan Pekerja Indonesia di Luar Negeri ialah adanya kewajiban untuk mengikuti program asuransi yang dalam hal ini disebut dengan Program Asuransi Wajib yang mana merupakan program yang diwajibkan peraturan perundang-undangan bagi seluruh atau kelompok tertentu dalam masyarakat guna mendapatkan perlindungan dan risiko tertentu, tidak termasuk program yang diwajibkan undang-undang untuk memberikan perlindungan dasar bagi masyarakat dengan mekanisme subsidi silang dalam penetapan manfaat dan Premi atau Kontribusinya (Pasal 1 Angka 32). Selain itu, Program Asuransi Wajib tersebut harus diselenggarakan secara kompetitif (Pasal 39).

Dalam Program Asuransi Wajib, Pasal 39 ayat (2) UU ini mengatur bahwa paling sedikit harus memuat kriteria sebagai berikut:

a. Cakupan kepesertaan;

b. Hak dan kewajiban Tertanggung atau Peserta;

c. Premi atau Kontribusi;

d. Manfaat atau santunan;

e. Tata cara klaim dan pembayaran manfaat atau santunan;

f. Kriteria penyelenggara;

g. Hak dan kewajiban penyelenggara; dan

h. Keterbukaan informasi.

Selain itu, pihak yang dapat menyelenggarakan Program Asuransi Wajib tersebut harus memenuhi persyaratan yang ditetapkan oleh Otoritas Jasa Keuangan (Pasal 39 Ayat (3)), kemudian Penyelenggara Program Asuransi Wajib dapat menawarkan manfaat tambahan dengan tambahan 
Premi atau Kontribusi, namun dilarang memaksa Pemegang Polis untuk menerima tawaran manfaat tambahan tersebut (Pasal 39 ayat (4) dan (5)). 16. Undang-Undang Nomor 23 Tahun 2014 tentang Pemerintahan Daerah UU Nomor 23 Tahun 2014 merupakan undang-undang yang menggantikan UU Nomor 12 tahun 2008 tentang Pemerintah Daerah. Beberapa pasal dari UU Nomor 23 Tahun 2014 terkait dengan UU Nomor 39 Tahun 2004. Pada Undang-Undang Nomor 23 tahun 2014 tentang Pemerintah Daerah mengembalikan kewenangan daerah yang sebelumnya menjadi wewenang pemerintah pusat. Undang-Undang Nomor 39 Tahun 2004 tentang Penempatan dan Perlindungan Tenaga Kerja Indonesia di Luar Negeri awalnya tidak memiliki konsistensi dengan UU Nomor 12 Tahun 2008 tentang Pemerintahan Daerah.

Pasal 10 UU nomor 12 tahun 2008 tentang Pemerintahan Daerah ini sebenarnya jelas bahwa urusan yang dilaksanakan oleh Pemerintah (pusat) hanya 6 point (Pasal 10 ayat (3) huruf a sampai dengan f). Tidak satupun dalam huruf tersebut yang secara eksplisit mengemukakan bahwa urusan ketenagakerjaan merupakan urusan Pemerintah (pusat) yang dengan kata lain seharusnya pengaturan, perlindungan tentang ketenagakerjaan merupakan urusan yang diwajibkan kepada Pemerintah Daerah. Jadi kalau ada undang-undang, maka banyak pasal yang mendelegasikan pengaturan lebih lanjut seharusnya didelegasikan kepada Pemerintah Daerah. Sehingga tepat dan sangat ideal kalau UU Nomor 39 Tahun 2004 banyak mendelegasikan pasal-pasalnya untuk 
diatur dalam Perda, walaupun mungkin ada Peraturan Pemerintah yang memberikan batasan-batasan minimal yang harus ada di Perda.

Namun pada UU Nomor 23 tahun 2014 tentang Pemerintahan Daerah dalam Bab IV, Bagian Kesatu dengan Sub Judul Klasifikasi Urusan Pemerintahan Pasal 9 ayat 1 menyebutkan bahwa: "Urusan Pemerintahan terdiri atas urusan pemerintahan absolut, urusan pemerintahan konkuren, dan urusan pemerintahan umum".

Pasal 9 ayat 3 kemudian menjelaskan yang menjadi urusan pemerintahan konkuren: "Urusan pemerintahan konkuren sebagaimana dimaksud pada ayat (1) adalah Urusan Pemerintahan yang dibagi antara Pemerintah Pusat dan Daerah provinsi dan Daerah kabupaten/kota".

Kemudian Pasal 11 dan Pasal 12 menjelaskan bahwa urusan pemerintahan konkuren wajib termasuk didalamnya mengenai tenaga kerja. Hal ini berkaitan dengan bagaimana pemerintah melindungi rakyatnya dan pemerintah daerah untuk melindungi masyarakatnya yang berada di daerah tertentu. Disebutkan pada bagian ketiga sub judul urusan Pemerintahan Konkuren, bahwa: "Urusan pemerintahan konkuren sebagaimana di maksud dalam Pasal 9 ayat (3) yang menjadi kewenangan Daerah terdiri atas Urusan Pemerintahan Wajib dan Urusan Pemerintahan Pilihan" (Pasal 11). Sedangkan, "Urusan Pemerintahan Wajib yang tidak berkaitan dengan Pelayanan Dasar sebagaimana dimaksud dalam Pasal 11 ayat (2) meliputi: a. tenaga kerja; b. ..dst" (Pasal 12). 
Sesungguhnya Otonomi Daerah memberikan kewenangan untuk mengurus sendiri urusan pemerintahan yang diberikan oleh pemerintahan daeran tidak dapat bertentangan dengan peraturan perundang-undangan yang lebih tinggi hierarkinya dan bertentangan dengan kepentingan umum.

Pada lampiran UU Nomor 23 Tahun 2014 tentang Pemerintahan Daerah dalam pembagian urusan pemerintahan konkuren antara pemerintah pusat dan daerah Kabupaten/Kota dapat dijelaskan melaui tabel berikut:

Tabel 4.4 Pembagian Urusan Pemerintahan Konkuren antara Pemerintah Pusat dan Daerah Kabupaten/Kota

\begin{tabular}{|c|c|c|c|c|}
\hline No & Sub-Bidang & $\begin{array}{l}\text { Pemerintah } \\
\text { Pusat }\end{array}$ & $\begin{array}{l}\text { Pemerintah } \\
\text { Provinsi }\end{array}$ & $\begin{array}{c}\text { Daerah } \\
\text { Kabupaten/Kota }\end{array}$ \\
\hline 1 & 2 & 3 & 4 & 5 \\
\hline 1 & $\begin{array}{l}\text { Pelatihan } \\
\text { Kerja dan } \\
\text { Produktivitas } \\
\text { Tenaga Kerja }\end{array}$ & $\begin{array}{l}\text { a. } \\
\text { Pengembangan } \\
\text { sistem dan } \\
\text { metode pelatihan } \\
\text { b. Penetapan } \\
\text { standar } \\
\text { kompetensi. } \\
\text { c. Pengembangan } \\
\text { program pelatihan } \\
\text { ketenagakerjaan, } \\
\text { ketransmigrasian, } \\
\text { produktivitas, dan } \\
\text { kewirausahaan. } \\
\text { d. Pelaksanaan } \\
\text { pelatihan untuk } \\
\text { kejuruan yang } \\
\text { bersifat strategis. } \\
\text { e. Penetapan } \\
\text { kualifikasi } \\
\text { instruktur, } \\
\text { penggerak } \\
\text { swadaya } \\
\text { masyarakat (PSM) } \\
\text { dan tenaga } \\
\text { pelatihan. } \\
\text { f. Pengembangan }\end{array}$ & $\begin{array}{l}\text { a. Pelaksanaan } \\
\text { pelatihan } \\
\text { berdasarkan } \\
\text { klaster } \\
\text { kompetensi. } \\
\text { b. Pelaksanaan } \\
\text { akreditasi } \\
\text { c. lembaga } \\
\text { pelatihan kerja. } \\
\text { d. Konsultansi } \\
\text { produktivitas } \\
\text { pada perusahaan } \\
\text { menengah. } \\
\text { e. Pengukuran } \\
\text { produktivitas } \\
\text { tingkat Daerah } \\
\text { provinsi. }\end{array}$ & $\begin{array}{l}\text { a. Pelaksanaan } \\
\text { pelatihan } \\
\text { berdasarkan unit } \\
\text { kompetensi. } \\
\text { b. Pembinaaan } \\
\text { lembaga } \\
\text { pelatihan kerja } \\
\text { swasta. } \\
\text { c. Perizinan dan } \\
\text { pendaftaran } \\
\text { lembaga } \\
\text { pelatihan kerja. } \\
\text { d. Konsultansi } \\
\text { produktivitas } \\
\text { pada perusahaan } \\
\text { kecil. } \\
\text { e. Pengukuran } \\
\text { produktivitas } \\
\text { tingkat Daerah } \\
\text { kabupaten/kota. }\end{array}$ \\
\hline
\end{tabular}




\begin{tabular}{|c|c|c|c|c|}
\hline & & $\begin{array}{l}\text { dan peningkatan } \\
\text { kompetensi } \\
\text { instruktur dan } \\
\text { PSM. } \\
\text { g. Penetapan } \\
\text { standar akreditasi } \\
\text { lembaga pelatihan } \\
\text { kerja. } \\
\text { h. Penerbitan izin } \\
\text { pemagangan luar } \\
\text { negeri. } \\
\text { i. Pemberian } \\
\text { lisensi lembaga } \\
\text { sertifikasi profesi. } \\
\text { j. Pelaksanaan } \\
\text { sertifikasi } \\
\text { kompetensi profesi } \\
\text { k. Pengembangan } \\
\text { sistem, metode, } \\
\text { alat dan teknik } \\
\text { peningkatan } \\
\text { produktivitas. } \\
\text { I. Penyadaran } \\
\text { produktivitas. } \\
\text { m. Konsultansi } \\
\text { produktivitas pada } \\
\text { perusahaan besar. } \\
\text { n. Pengukuran } \\
\text { produktivitas } \\
\text { tingkat nasional. }\end{array}$ & & \\
\hline 2 & $\begin{array}{l}\text { Penempatan } \\
\text { Tenaga Kerja }\end{array}$ & $\begin{array}{l}\text { a. Pelayanan antar } \\
\text { kerja } \\
\text { nasional. } \\
\text { b. Pengantar } \\
\text { kerja. } \\
\text { c. Penerbitan izin } \\
\text { lembaga } \\
\text { penempatan } \\
\text { tenaga kerja } \\
\text { swasta (LPTKS) } \\
\text { lebih dari } \\
\text { d. } 1 \text { (satu) Daerah } \\
\text { provinsi. } \\
\text { e. Penerbitan izin } \\
\text { pelaksana } \\
\text { penempatan } \\
\text { tenaga kerja } \\
\text { indonesia swasta } \\
\text { (PPTKIS). } \\
\text { f. Pengembangan } \\
\text { bursa } \\
\text { kerja dan } \\
\text { informasi pasar }\end{array}$ & $\begin{array}{l}\text { a. Pelayanan } \\
\text { antar kerja lintas } \\
\text { Daerah } \\
\text { kabupaten/kota } \\
\text { dalam } 1 \text { (satu) } \\
\text { Daerah provinsi. } \\
\text { b. Penerbitan izin } \\
\text { LPTKS lebih dari } \\
1 \text { (satu) Daerah } \\
\text { kabupaten/kota } \\
\text { dalam 1(satu) } \\
\text { Daerah provinsi. } \\
\text { c. Pengelolaan } \\
\text { informasi pasar } \\
\text { kerja dalam } 1 \\
\text { (satu) } \\
\text { d. Daerah } \\
\text { provinsi. } \\
\text { e. Perlindungan } \\
\text { TKI di luar negeri } \\
\text { (pra dan purna } \\
\text { penempatan) di } \\
\text { Daerah provinsi. }\end{array}$ & $\begin{array}{l}\text { a. Pelayanan } \\
\text { antar kerja di } \\
\text { Daerah } \\
\text { kabupaten/kota } \\
\text { b. Penerbitan izin } \\
\text { LPTKS } \\
\text { dalam } 1 \text { (satu) } \\
\text { Daerah } \\
\text { kabupaten/kota. } \\
\text { c. Pengelolaan } \\
\text { informasi } \\
\text { pasar kerja } \\
\text { dalam Daerah } \\
\text { kabupaten/kota } \\
\text { d. Perlindungan } \\
\text { TKI di luar } \\
\text { negeri (pra dan } \\
\text { purna } \\
\text { penempatan) di } \\
\text { Daerah } \\
\text { kabupaten/kota } \\
\text { e. Penerbitan } \\
\text { perpanjangan }\end{array}$ \\
\hline
\end{tabular}




\begin{tabular}{|c|c|c|c|c|}
\hline & & $\begin{array}{l}\text { kerja nasional dan } \\
\text { di luar negeri. } \\
\text { g. Perlindungan } \\
\text { tenaga kerja } \\
\text { Indonesia (TKI) di } \\
\text { luar negeri. } \\
\text { h. Pengesahan } \\
\text { rencana } \\
\text { penggunaan } \\
\text { tenaga kerja } \\
\text { asing (RPTKA) } \\
\text { baru, } \\
\text { pengesahan } \\
\text { RPTKA } \\
\text { perubahan seperti } \\
\text { jabatan, lokasi, } \\
\text { jumlah } \\
\text { tenaga kerja } \\
\text { asing, dan } \\
\text { kewarganegaraan } \\
\text { serta RPTKA } \\
\text { perpanjangan } \\
\text { lebih dari } 1 \text { (satu) } \\
\text { Daerah provinsi. } \\
\text { i. Penerbitan izin } \\
\text { mempekerjakan } \\
\text { tenaga } \\
\text { kerja asing (IMTA) } \\
\text { baru } \\
\text { dan perpanjangan } \\
\text { IMTA } \\
\text { yang lokasi kerja } \\
\text { lebih } \\
\text { dari } 1 \text { (satu) } \\
\text { Daerah } \\
\text { provinsi. }\end{array}$ & $\begin{array}{l}\text { f. Pengesahan } \\
\text { RPTKA } \\
\text { perpanjangan } \\
\text { yang tidak } \\
\text { mengandung } \\
\text { perubahan } \\
\text { jabatan, jumlah } \\
\text { TKA, dan lokasi } \\
\text { kerja dalam } 1 \\
\text { (satu) } \\
\text { g. Daerah } \\
\text { provinsi. } \\
\text { h. Penerbitan } \\
\text { perpanjangan } \\
\text { i. IMTA yang } \\
\text { lokasi kerja lebih } \\
\text { dari } 1 \text { (satu) } \\
\text { Daerah } \\
\text { kabupaten/kota } \\
\text { dalam } 1 \text { (satu) } \\
\text { Daerah provinsi. }\end{array}$ & $\begin{array}{l}\text { IMTA yang lokasi } \\
\text { kerja } \\
\text { dalam } 1 \text { (satu) } \\
\text { Daerah } \\
\text { kabupaten/kota. }\end{array}$ \\
\hline 3 & $\begin{array}{l}\text { Hubungan } \\
\text { Industrial }\end{array}$ & $\begin{array}{l}\text { a. Pengesahan } \\
\text { peraturan } \\
\text { perusahaan dan } \\
\text { pendaftaran } \\
\text { perjanjian } \\
\text { kerja bersama } \\
\text { untuk perusahaan } \\
\text { yang mempunyai } \\
\text { wilayah kerja lebih } \\
\text { dari 1 (satu) } \\
\text { Daerah provinsi. } \\
\text { b. Pencegahan } \\
\text { dan penyelesaian } \\
\text { perselisihan } \\
\text { hubungan } \\
\text { industrial,mogok } \\
\text { kerja dan }\end{array}$ & $\begin{array}{l}\text { a. Pengesahan } \\
\text { peraturan } \\
\text { perusahaan dan } \\
\text { pendaftaran } \\
\text { perjanjian kerja } \\
\text { bersama untuk } \\
\text { yang mempunyai } \\
\text { wilayah kerja } \\
\text { lebih dari } 1 \text { (satu) } \\
\text { kabupaten/kota } \\
\text { dalam } 1 \text { (satu) } \\
\text { daerah provinsi. } \\
\text { b. Pencegahan } \\
\text { dan penyelesaian } \\
\text { perselisihan } \\
\text { hubungan } \\
\text { industrial, }\end{array}$ & $\begin{array}{l}\text { a. Pengesahan } \\
\text { peraturan } \\
\text { perusahaan dan } \\
\text { pendaftaran } \\
\text { perjanjian kerja } \\
\text { bersama untuk } \\
\text { perusahaan yang } \\
\text { hanya beroperasi } \\
\text { dalam } 1 \text { (satu) } \\
\text { daerah } \\
\text { kabupaten/kota. } \\
\text { b. Pencegahan } \\
\text { dan } \\
\text { penyelesaian } \\
\text { perselisihan } \\
\text { hubungan } \\
\text { industrial, }\end{array}$ \\
\hline
\end{tabular}




\begin{tabular}{|c|c|c|c|c|}
\hline & & $\begin{array}{l}\text { penutupan yang } \\
\text { berakibat/ } \\
\text { berdampak pada } \\
\text { kepentingan } \\
\text { nasional/ } \\
\text { internasional. }\end{array}$ & $\begin{array}{l}\text { mogok kerja } \\
\text { dan penutupan } \\
\text { perusahaan yang } \\
\text { berakibat/ } \\
\text { berdampak pada } \\
\text { kepentingan } \\
\text { di } 1 \text { (satu) daerah } \\
\text { provinsi. } \\
\text { c. Penempatan } \\
\text { upah minimum } \\
\text { provinsi (UMP), } \\
\text { upah minimum } \\
\text { sektoral } \\
\text { provinsi (UMSP), } \\
\text { upah minimum } \\
\text { kabupaten/ } \\
\text { kota } \\
\text { (UMK) dan upah } \\
\text { minimum sektoral } \\
\text { kabupaten/ } \\
\text { kota } \\
\text { (UMSK). }\end{array}$ & $\begin{array}{l}\text { mogok kerja dan } \\
\text { penutupan } \\
\text { perusahaan di } \\
\text { daerah } \\
\text { kabupaten/kota }\end{array}$ \\
\hline 4 & $\begin{array}{l}\text { Pengawasan } \\
\text { Ketenaga- } \\
\text { kerjaan }\end{array}$ & $\begin{array}{l}\text { a. Penetapan } \\
\text { sistem pengawas } \\
\text { ketenagakerjaan. } \\
\text { b. Pengelolaan } \\
\text { tenaga } \\
\text { pengawas } \\
\text { ketenagakerjaan. }\end{array}$ & $\begin{array}{l}\text { Penyelenggaraan } \\
\text { pengawasan } \\
\text { ketenagakerjaan. }\end{array}$ & \\
\hline
\end{tabular}

Berdasarkan lampiran tersebut diketahui secara jelas mengenai pembagian tugas yang dilakukan oleh pemerintah daerah dan pemerintah pusat.

17. Peraturan Menteri Ketenagakerjaan Nomor 22 Tahun 2014 tentang Pelaksanaan Penempatan dan Perlindungan Tenaga Kerja Indonesia di Luar Negeri

Terbitnya Permenaker Nomor 22 Tahun 2014 menimbulkan polemik, terutama terkait dengan isu penghapusan Kartu Tenaga Kerja Luar Negeri (KTKLN) yang digaungkan oleh Presiden Jokowi beberapa waktu lalu. Ketentuan mengenai KTKLN sebagaimana Pasal 63 ayat (2) UU Nomor 39 Tahun 2004 tentang Penempatan dan Perlindungan Tenaga Kerja Indonesia di Luar Negeri, yaitu bahwa: "Ketentuan 
mengenai bentuk, persyaratan dan tata cara memperoleh KTKLN diatur lebih lanjut dengan Peraturan Menteri”. Disamping itu KTKLN merupakan dokumen yang harus dimiliki oleh calon TKI untuk dapat ditempatkan di luar negeri (Pasal 51 huruf j UU Nomor 39 Tahun 2004). Namun dalam Permenaker ketentuan tersebut tidak ada, hal ini dijadikan pembahasan bahwa KTKLN sudah dibatalkan, sedangkan belum ada pembaharuan atau penggantian terhadap UU Nomor 39 Tahun 2004 tentang Penempatan dan Perlindungan Tenaga Kerja Indonesia di Luar Negeri. Selain daripada hal tersebut, ada ketentuan lain yang belum diatur di dalam UU namun tertuang di dalam Permenaker. Antara lain ketentuan sebagaimana Pasal 1 angka 3 mengenai TKI Perseorangan, bahwa yang dimaksud dengan TKI Perseorangan adalah TKI yang bekerja pada pengguna berbadan hukum.

Lex superior derogate lex inferior, merupakan suatu asas ilmu hukum, dimana peraturan perundang-undangan yang jenjangnya lebih rendah tidak boleh bertentangan dengan peraturan perundang-undangan yang berada di jenjang yang lebih tinggi. Selain itu menurut Pasal 8 ayat (2) UU No. 12 Tahun 2011 tentang Pembentukan Peraturan Perundangundangan disebutkan bahwa, "Peraturan Perundang-undangan sebagaimana dimaksud pada ayat (1) diakui keberadaannya dan mempunyai kekuatan hukum mengikat sepanjang diperintahkan oleh Peraturan Perundang-undangan yang lebih tinggi atau dibntuk berdasarkan kewenangan". 
Penerbitan Permenaker Nomor 22 Tahun 2014 seharusnya menjadi penjelasan bagi UU Nomor 39 Tahun 2004. Ketentuan mengenai KTKLN masih diatur di dalam UU, lalu bagaimana dasar pertimbangan meniadakan aturan mengenai KTKLN di dalam peraturan menteri yang seharusnya menjalankan amanat dari UU yang berada di atasnya?

18. Peraturan Menteri Ketenagakerjaan Nomor 23 Tahun 2014 tentang Tata Cara Kepulangan Tenaga Kerja Indonesia dari Negara Penempatan ke Daerah Asal Secara Mandiri

Perihal kepulangan TKI ke daerah asal dapat dilakukan secara mandiri. Pasal 2 Permenaker Nomor 23 Tahun 2014 menyebutkan bahwa, kepulangan TKI ke daerah asal dapat dilakukan secara mandiri, apabila TKI telah memiliki kemampuan mengurus dirinya sendiri, meliputi: (a) Pengurusan dokumen kepulangan; (b) Secara fisik dan mental dapat pulang tanpa bantuan pihak lain; dan (c) Mampu menjaga keamanan dan keselamatan diri serta barang bawaannya; dan (d) Mampu memilih dan menentukan moda transportasi ke daerah asal.

Bahkan TKI yang pulang secara mandiri dapat pulang langsung ke daerah asal tanpa bantuan petugas (Pasal 7 ayat (1)). Setiap TKI yang akan pulang ke daerah asal secara mandiri wajib melapor kepada Atase Ketenagakerjaan atau Kepala Bidang Ketenagakerjaan atau pejabat lain yang ditunjuk oleh kepala Perwakilan Republik Indonesia di negara penempatan atau KDEI apabila tidak memiliki Atase Ketenagakerjaan (Pasal 4 ayat (1)). Dan bagi TKI yang pulang langsung ke daerah asal tanpa bantuan petugas, melaporkan kepulangannya kepada dinas yang 
bertanggung jawab di bidang ketenagakerjaan kabupaten/kota daerah asal (Pasal 7 ayat (2)).

19. Peraturan Menteri Ketenagakerjaan Nomor 24 Tahun 2014 tentang Tata Cara Pemberian, Perpanjangan dan Pencabutan Surat Izin Pelaksana Penempatan Tenaga Kerja Indonesia

Berkaitan dengan pencabutan Surat Izin Pelaksana Penempatan Tenaga Kerja Indonesia (SIPPTKI), ketentuan dalam Pasal 16A menyebutkan bahwa PPTKIS yang telah dijatuhi sanksi administrative berupa pencabutan SIPPTKI,maka penanggungjawab PPTKIS tersebut dilarang menjadi penanggungjawab pada PPTKIS lain untuk jangka waktu 5 (lima) tahun.

Peraturan yang berasal dari hukum nasional terkait penempatan dan perlindungan TKI secara singkat dipaparkan pada tabel berikut: 
Tabel 4.5 Kajian Peraturan Perundang-Undangan terkait Penempatan dan Perlindungan TKI di Luar Negeri dari Hukum Nasional

\begin{tabular}{|c|c|c|}
\hline No. & Peraturan & Tentang \\
\hline 1. & $\begin{array}{l}\text { Undang-Undang Dasar } \\
\text { Negara Republik } \\
\text { Indonesia Tahun } 1945\end{array}$ & - \\
\hline 2. & Undang-Undang & Kitab Undang-Undang Hukum Pidana \\
\hline 3. & Undang-Undang & Kitab Undang-Undang Hukum Perdata \\
\hline 4. & UU No. 37 Tahun 1999 & Hubungan Luar Negeri \\
\hline 5. & UU No. 39 Tahun 1999 & Hak Asasi Manusia \\
\hline 6. & UU No. 21 Tahun 2000 & Serikat Pekerja \\
\hline 7. & UU No. 13 Tahun 2003 & Ketenagakerjaan \\
\hline 8. & UU No. 23 Tahun 2004 & $\begin{array}{l}\text { Penghapusan Kekerasan dalam Rumah } \\
\text { Tangga }\end{array}$ \\
\hline 9. & UU No. 40 Tahun 2004 & Sistem Jaminan Sosial Nasional \\
\hline 10. & UU No. 21 Tahun 2007 & $\begin{array}{l}\text { Pemberantasan Tindak } \\
\text { Perdagangan Orang }\end{array}$ \\
\hline 11. & UU No. 11 Tahun 2009 & Kesejahteraan Sosial \\
\hline 12. & UU No. 6 Tahun 2011 & Keimigrasian \\
\hline 13. & UU No. 24 Tahun 2011 & Badan Penyelenggara Jaminan Sosial \\
\hline 14. & UU No. 31 Tahun 2014 & Perlindungan Saksi dan Korban \\
\hline 15. & UU No. 40 Tahun 2014 & Perasuransian \\
\hline 16. & UU No. 23 Tahun 2014 & Pemerintahan Daerah \\
\hline 17. & $\begin{array}{lll}\text { Permenaker } & \text { No. } & 22 \\
\text { Tahun } 2014 & & \end{array}$ & $\begin{array}{l}\text { Pelaksanaan Penempatan Dan } \\
\text { Perlindungan Tenaga Kerja Indonesia di } \\
\text { Luar Negeri }\end{array}$ \\
\hline 18. & $\begin{array}{lll}\text { Permenaker } & \text { No. } & 23 \\
\text { Tahun } 2014 & & \end{array}$ & $\begin{array}{l}\text { Tata Cara Kepulangan Tenaga Kerja } \\
\text { Indonesia Dari Negara Penempatan Ke } \\
\text { Daerah Asal Secara Mandiri }\end{array}$ \\
\hline 19. & $\begin{array}{l}\text { Permenaker } \\
\text { Tahun } 2014\end{array}$ & $\begin{array}{l}\text { Tata Cara Pemberian, Perpanjangan } \\
\text { Dan Pencabutan Surat Izin Pelaksana } \\
\text { Penempatan Tenaga Kerja Indonesia }\end{array}$ \\
\hline
\end{tabular}

Peraturan terkait ini merupakan hasil kompilasi dari Naskah Akademik Rancangan Undang-Undang Perlindungan Pekerja Indonesia di Luar Negeri (NA RUU PPILN) versi 7 Juni 2012 yang kemudian diperbaharui kembali dalam NA RUU PPILN versi 27 Mei 2015 dengan pemisahan antara hukum nasional dan hukum hasil ratifikasi. Berdasarkan hasil sinkronisasi ini pada tabel 4.5 di atas menunjukkan 19 peraturan 
terkait yang terdiri atas 16 jenis Undang-Undang dan 3 jenis Peraturan Menteri Ketenagakerjaan RI.

Undang-Undang yang disinkronisasi pada tabel 4.5 di atas merupakan Undang-Undang yang memiliki keterkaitan dengan upaya penempatan dan perlindungan TKI. Secara umum Undang-Undang tersebut melindungi TKI pada tiga tahapan yakni masa pra-penempatan, masa penempatan dan purna-penempatan. Misalnya: KUH Pidana dan KUH Perdata melindungi WNI/TKI dari perbuatan yang melanggar hukum di bidang Pidana dan Perdata di masa pra-penempatan dan purnapenempatan. Kemudian, UU No. 23 Tahun 2014 tentang Pemerintahan Daerah mengatur tentang kewenangan pemerintah pusat, provinsi maupun kabupaten/kota dalam memberikan perlindungan terhadap TKI di masa pra dan purna, sedangkan urusan di masa penempatan lebih dititikberatkan oleh UU yang mengikat perwakilan Indonesia di luar negeri seperti UU No. 37 Tahun 1999 tentang Hubungan Luar Negeri dan UU No. 39 Tahun 1999 tentang Hak Asasi Manusia.

\section{Hukum Hasil Ratifikasi}

1. Undang-Undang Nomor 1 Tahun 1982 tentang Pengesahan Konvensi Wina mengenai Hubungan Diplomatik Beserta Protokol Opsionalnya Mengenai Hal Memperoleh Kewarganegaraan (Vienna Convention on Diplomatic Relations and Optional Protocol to the Vienna Convention on Diplomatic Relations Concerning Acquisition of Nationality, 1961) dan Pengesahan Konvensi Wina mengenai Hubungan Konsuler Beserta Protokol Opsionalnya Mengenai Hal Memperoleh Kewarganegaraan (Vienna Convention on Consular Relations and Optional Protocol to the Vienna Convention on Consular Relation Concerning Acquisition of Nationality, 1963)

Konvensi ini yang terdiri dari 79 Pasal yang keseluruhannya mengenai hubungan konsuler, hak-hak istimewa dan kekebalan- 
kekebalannya akan meningkatkan hubungan persahabatan antara bangsa-bangsa tanpa membedakan ideologi, sistim politik atau sistim sosialnya. Hak istimewa dan kekebalan tersebut diberikan hanyalah guna mnjamin pelaksanaan fungsi perwakilan konsuler secara efisien Konvensi mengatur antara lain hubungan konsuler pada umumnya, fasilitas, hakhak istimewa dan kekebalan Kantor Perwakilan Konsuler, pejabat konsuler dan anggota perwakilan konsuler lainnya serta tentang pejabatpejabat konsul kehormatan dan konsulat-konsulat kehormatan.

Baik Konvensi Wina mengenai Hubungan Diplomatik maupun Konvensi Wina mengenai hubungan Konsuler masing-masing dilengkapi dengan Protokol Opsional mengenai hal memperoleh Kewarganegaraan dan Protokol Opsional mengenai Penyelesaian Sengketa Secara Wajib. Indonesia dapat menerima seluruh isi Konvensi Wina mengenai Hubungan Diplomatik Beserta Protokol Opsionalnya mengenai hal memperoleh Kewarganegaraan dan Konvensi Wina mengenai Hubungan Konsuler Beserta Protokol Opsionalnya mengenai hal memperoleh Kewarganegaraan, kecuali Protokol Opsional mengenai Penyelesaian Sengketa Secara Wajib. Pengecualian ini karena Pemerintah Indonesia lebih mengutamakan penyelesaian sengketa melalui perundingan dan konsultasi atau musyawarah antara negara-negara yang bersengketa.

Protokol Opsional mengenai hal memperoleh Kewarganegaraan mengatur bahwa anggota-anggota perwakilan diplomatik dan perwakilan konsuler yang bukan warganegara penerima dan perwakilan konsuler yang bukan warganegara penerima dan keluarganya tidak akan 
memperoleh kewarganegaraan negara penerima tersebut semata-mata karena berlakunya hukum negara penerima tersebut.

2. Undang-Undang Nomor 17 Tahun 1984 tentang Pengesahan Konvensi mengenai Penghapusan Segala Bentuk Diskriminasi terhadap Wanita (Convention on the Ellimination of All Forms of Discrimination Against Women)

Indonesia telah meratifikasi Konvensi Penghapusan Segala Bentuk Diskriminasi terhadap Perempuan (Convention on The Elimination of All Forms of Discrimination Against Women - CEDAW)) dengan Undangundang Nomor 7 Tahun 1984. Konvensi ini secara tegas menuntut adanya kesetaraan sosial, pemberantasan perdagangan anak dan eksploitasi seksual, kesetaraan dalam pendidikan, perawatan kesehatan, dan kesetaraan dalam kehidupan ekonomi dan sosial.

Dalam Pasal 11 ayat (1) diatur mengenai kewajiban Pihak yang meratifikasi konvensi untuk melakukan semua upaya penghapusan diskriminasi terhadap perempuan dalam bidang pekerjaan. Selengkapnya Pasal 11 ayat (1) menyatakan: "Negara-negara Pihak wajib untuk melakukan semua upaya yang tepat untuk menghapuskan diskriminasi terhadap perempuan dalam bidang pekerjaan dalam rangka untuk memastikan persamaan hak antara perempuan dan laki-laki terutama":

a. Hak untuk bekerja sebagai suatu hak yang melekat pada semua umat manusia;

b. Hak atas kesempatan kerja yang sama, termasuk penerapan kriteria seleksi yang sama terhadap suatu pekerjaan;

c. Hak atas kebebasan memilih profesi dan pekerjaan, hak atas pengangkatan, keamanan bekerja dan seluruh tunjangan dan 
kondisi pelayanan, dan hak untuk mendapat pelatihan kejuruan dan pelatihan ulang, termasuk magang, pelatihan kejuruan lanjutan serta pelatihan kembali.

d. Hak atas persamaan pendapatan termasuk tunjangan. dan persamaan perlakuan sehubungan dengan pekerjaan yang sama nilainya, seperti juga persamaan perlakuan dalam melakukan evaluasi terhadap kualitas kerja;

e. Hak atas jaminan sosial, terutama dalam hal pensiun, pengangguran, sakit, cacat dan lanjut usia, serta semua bentuk ketidakmampuan untuk bekerja, seperti juga hak atas masa cuti yang dibayar;

f. Hak atas perlindungan kesehatan dan keselamatan dalam kondisi kerja, termasuk atas perlindungan untuk reproduksi.

3. Undang-Undang Nomor 5 Tahun 1998 tentang Pengesahan Konvensi menentang Penyiksaan dan Perlakuan atau Penghukuman Lain yang Kejam, Tidak Manusiawi atau Merendahkan Martabat Manusia (Convention against Torture and Other Cruel, Inhuman or Degrading Treatment or Punishment)

Konvensi Menentang Penyiksaan atau yang dalam bahasa resminya adalah Konvensi Menentang Penyiksaan dan Perlakuan atau Hukuman Lain yang Kejam, Tidak Manusiawi, dan Merendahkan Martabat Manusia atau yang dalam bahasa Inggris lebih dikenal dengan The United Nations Convention Against Torture and Other Cruel, Inhuman or Degrading Treatment or Punishment adalah sebuah instrumen hukum internasional yang bertujuan untuk mencegah penyiksaan terjadi di seluruh dunia. 
Konvensi ini mewajibkan negara-negara pihak untuk mengambil langkah-langkah efektif untuk mencegah penyiksaan terjadi di wilayahnya dan Konvensi melarang pemulangan paksa atau ekstradisi terhadap seseorang ke Negara lain di mana ia berhadapan dengan risiko penyiksaan

Indonesia sendiri meratifikasi konvensi ini melalui UU Nomor 5 Tahun 1998 pada 28 September 1998. Melalui UU ini Indonesia juga melakukan deklarasi terhadap ketentuan Pasal 20 ayat (1), ayat (2), dan ayat (3) serta melakukan reservasi terhadap ketentuan Pasal 30 ayat (1) dari konvensi ini.

Pasal 1 Konvensi Menentang Penyiksaan mengedepankan sebuah definisi mengenai tindakan-tindakan yang merupakan "penyiksaan" yang disepakati secara internasional. Pasal ini menetapkan bahwa, "penyiksaan" berarti setiap perbuatan yang dilakukan dengan sengaja, sehingga menimbulkan rasa sakit atau penderitaan yang luar biasa, baik jasmani maupun rohani, pada seseorang untuk memperoleh pengakuan atau keterangan dari orang itu atau orang ketiga, dengan menghukumnya atas suatu perbuatan yang telah dilakukan atau diduga telah dilakukan oleh orang itu atau orang ketiga, atau mengancam atau memaksa orang itu atau orang ketiga, atau untuk suatu alasan apa pun yang didasarkan pada setiap bentuk diskriminasi, apabila rasa sakit atas penderitaan tersebut ditimbulkan oleh, atas hasutan dari, dengan persetujuan atau sepengetahuan seorang pejabat publik atau orang lain yang bertindak di dalam kapasitas publik. Hal itu tidak meliputi rasa sakit atau penderitaan 
yang semata-mata timbul dari, melekat pada atau diakibatkan oleh suatu sanksi hukum yang berlaku.

Unsur-unsur pokok dari apa yang mendasari penyiksaan terkandung dalam Pasal 1 Konvensi Menentang Penyiksaan mencakup: (a) timbulnya rasa sakit atau penderitaan mental atau fisik yang luar biasa; (b) oleh atau dengan persetujuan atau sepengetahuan pejabat-pejabat Negara yang berwenang; dan (c) Untuk suatu tujuan tertentu, seperti mendapatkan informasi, penghukuman atau intimidasi.

Perlakuan kejam, dan perlakuan atau penghukuman yang tidak manusiawi atau merendahkan martabat manusia juga merupakan istilahistilah hukum. Istilah-istilah ini merujuk pada perlakuan sewenang-wenang yang tidak harus ditimbulkan untuk suatu tujuan tertentu, tetapi harus terdapat suatu niat untuk menyingkapkan individu-individu pada kondisikondisi yang sama dengan atau berakibat pada perlakuan sewenangwenang. Menyingkapkan seseorang pada kondisikondisi yang layak dipercaya merupakan perlakuan sewenang-wenang akan menimbulkan tanggung jawab atas penderitaan yang ditimbulkan. Perlakuan yangmerendahkan martabat manusia dapat mencakup rasa sakit atau penderitaan yang tidak sehebat penyiksaan atau perlakuan kejam atau tidak manusiawi dan padaumumnya akan mencakup penghinaan dan penurunan harga diri si korban.

4. Undang-Undang Nomor 19 Tahun 1999 tentang Pengesahan Konvensi ILO mengenai Penghapusan Kerja Paksa (ILO Convention No. 105 Concerning the Abolition of Forced Labour) 
Pokok-Pokok Konvensi ini adalah sebagai berikut:

1) Negara anggota ILO yang mengesahkan Konvensi ini harus melarang dan tidak boleh menggunakan setiap bentuk kerja paksa sebagai alat penekanan politik, alat pengerahan untuk tujuan pembangunan, alat mendisiplinkan pekerja, sebagai hukuman atas keterlibatan dalam pemogokan dan sebagai tindakan diskriminasi.

2) Negara anggota ILO yang mengesahkan Konvensi ini harus mengambil tindakan yang menjamin penghapusan kerja paksa dengan segera dan menyeluruh.

3) Negara anggota ILO yang mengesahkan Konvensi ini harus melaporkan pelaksanaannya.

5. Undang-Undang Nomor 20 Tahun 1999 tentang Pengesahan Konvensi ILO mengenai Usia Minimum untuk Diperbolehkan Bekerja (ILO Convention No. 138 Concerning Minimum Age for Admission to Employment)

Negara Republik Indonesia yang berdasarkan Pencasila dan Undang-Undang Dasar 1945 adalah negara hukum yang menjunjung tinggi harkat dan martabat manusia sehingga anak sebagai generasi penerus bangsa wajib memperoleh jaminan perlindungan agar dapat tumbuh dan berkembang secara sehat dan wajar, baik jasmani dan rohani, maupun sosial dan intelektual. Indonesia sebagai bagian masyarakat internasional menghormati, menghargai, dan menjunjung tinggi prinsip dan tujuan Piagam Perserikatan Bangsa-Bangsa, serta Deklarasi Universal Hak-hak Asasi Manusia Tahun 1948, Deklarasi Philadelphia Tahun 1944, Konstitusi Organisasi Ketenagakerjaan Internasional (ILO), dan Konvensi Hak-hak Anak Tahun 1989. Konferensi 
Ketenagakerjan Internasional yang kelima puluh delapan tanggal 26 Juni 1973, telah menyetujui ILO Convention No. 138 Concerning Minimum Age for Admission to Employment (Konvensi ILO mengenai Usia Minimum untuk Diperbolehkan Bekerja).

Konvensi tersebut selaras dengan keinginan bangsa Indonesia untuk secara terus menerus menegakkan dan meningkatkan pelaksanaan hak-hak dasar anak dalam kehidupan bermasyarakat, berbangsa, dan bernegara. Berdasarkan pertimbangan tersebut Pemerintah Indonesia menetapkan Undang-Undang Republik Indonesia Nomor 20 Tahun 1999 Tentang Pengesahan Konvensi ILO Nomor 138 Mengenai Usia Minimum Untuk Diperbolehkan Bekerja.

Pokok-pokok konvensi ini adalah sebagai berikut:

a. Negara anggota ILO yang mengesahkan Konvensi ini wajib menetapkan kebijakan nasional untuk menghapus praktek mempekerjakan anak dan meningkatkan usia minimum untuk diperbolehkan bekerja.

b. Mengenai pengaturan umur pada Pasal 2 ayat 3 disebutkan bahwa batas usia yang ada dalam aturan tersebut adalah usia tamat sekolah atau 15 tahun. Kemudian muncul mengenai pengecualian pada ayat 4 yang menngecualikan daerah yang belum cukup berkembang dikecualikan batas minimum usia menjadi 14 tahun. Untuk pekerjaan-pekerjaan yang membahayakan kesehatan, keselamatan, atau moral anak harus diupayakan tidak boleh kurang dari 18 (delapan belas) 
tahun (Pasal 3), kecuali untuk pekerjaan ringan tidak boleh kurang dari 16 (enam belas) tahun (Pasal 3 ayat (2)).

c. Negara anggota ILO yang mengesahkan Konvensi ini wajib menetapkan usia minimum untuk diperbolehkan bekerja, aturan mengenai jam kerja, dan menetapkan hukuman atau sanksi guna menjamin pelaksanaannya.

d. Negara anggota ILO yang mengesahkan Konvensi ini wajib melaporkan pelaksanaannya (Pasal 4 ayat (2)).

6. Undang-Undang Nomor 21 Tahun 1999 tentang Pengesahan Konvensi ILO mengenai Diskriminasi dalam Pekerjaan dan Jabatan (ILO Convention No. 111 Concerning Discrimination in Respect of Employment and Occupation)

Adapun yang menjadi pokok-pokok konvensi ini adalah:

e. Negara anggota ILO yang mengesahkan Konvensi ini wajib melarang setiap bentuk diskriminasi dalam pekerjaan dan jabatan termasuk dalam memperoleh pelatihan dan keterampilan yang didasarkan atas kulit, jenis kelamin, agama, pandangan politik, kebangan atau asal usul keturunan.

b. Negara anggota ILO yang mengesahkan Konvensi ini wajib mengambil langkah-langkah kerja sama dalam peningkatan pentaatan pelaksanaannya, peraturan perundang-undangan, administrasi, penyesuaian kebijaksanaan, pengawasan, pendidikan dan pelatihan.

c. Negara anggota ILO yang mengesahkan Konvensi ini wajib melaporkan pelaksanaannya. 
7. Undang-Undang Nomor 11 Tahun 2005 tentang Pengesahan Konvenan Internasional tentang Hak-Hak Ekonomi, Sosial dan Budaya (International Convenant on Economic, Social and Cultural Rights)

Konvenan Internasional tentang Hak-hak Ekonomi, Sosial dan Budaya mulai berlaku pada tanggal 3 Januari 1976, kemudian Indonesia meratifikasi dengan Undang-Undang Nomor 11 tahun 2005. Kovenan ini mengukuhkan dan menjabarkan pokok-pokok HAM di bidang ekonomi, sosial dan budaya dari DUHAM dalam ketentuan-ketentuan yang mengikat secara hukum. Kovenan terdiri dari pembukaan dan pasal-pasal yang mencakup 31 (tiga puluh satu) pasal. yang diatur dalam Kovenan ini dalam kaitannya dengan individu lain dan masyarakatnya, dan mengakui bahwa, sesuai dengan DUHAM, cita-cita umat manusia untuk menikmati kebebasan sipil dan politik serta kebebasan dari rasa takut dan kekurangan hanya dapat tercapai apabila telah tercipta kondisi bagi setiap orang untuk dapat menikmati hak-hak ekonomi, sosial dan budaya serta hak-hak sipil dan politiknya.

Pasal 6 sampai dengan Pasal 15 mengakui hak asasi setiap orang di bidang ekonomi, sosial, dan budaya, yakni hak atas pekerjaan (Pasal 6), hak untuk menikmati kondisi kerja yang adil dan menyenangkan (Pasal 7), hak untuk membentuk dan ikut serikat buruh (Pasal 8), hak atas jaminan sosial, termasuk asuransi sosial (Pasal 9), hak atas perlindungan dan bantuan yang seluas mungkin bagi keluarga, ibu, anak, dan orang muda (Pasal 10), hak atas standar kehidupan yang memadai (Pasal 11), hak untuk menikmati standar kesehatan fisik dan mental yang tertinggi yang dapat dicapai (Pasal 12), hak atas pendidikan (Pasal 13 dan 14). 
Setiap orang berhak untuk mendpatkan pekerjaan yang layak seperti yang termuat dalam Pasal 6. Pekerja Indonesia baik diluar ataupun didalam negeri berhak untuk mendapatkan pekerjaan yang layak dengan upah yang layak. Dalam menjalankan pekerjaannya pekerja dilindungi dari rasa aman, perasaan yang menyenangkan dalam melaksanakan pekerjaan akan mempengaruhi kinerja para pekerja itu sendiri. Kemudian agar dapat berinteraksi dengan dunia luar dan todak merasa terkekang, maka pekerja diberikan hak untuk berserikat atau mengikuti organisasi yang dapat menunjang kehidupannya.

Pekerjaan yang dilakukan oleh pekerj baik di luar atau didalam negeri juga memiliki resiko pekerjaan. Resiko dari kecelakaan hingga resiko dari bahaya kesehatan seperti sakit, oleh karena itu pekerja membutuhkan adanya suatu jaminan social dan jaminan kesehatan agar tidak perlu menghawatirkan apabila terjadi suatu resiko tertentu.

Pekerja Indonesia yang berada didalam atau diluar negri merupakan subyek yang disebut sebagai manusia. Manusia membutuhkan standard kehidupan yang memadai. Hal ini sebagai perwujudan dari adanya keinginan alami manusia untuk mewujudkan kehidupan yang sejahtera, nyaman dan aman.

8. Undang-Undang Nomor 12 Tahun 2005 tentang Pengesahan Konvenan Internasional tentang Hak-Hak Sipil dan Politik (International Convenant on Civil and Political Rights)

Konvenan tentang Hak-Hak Sipil dan politik bersama-sama dengan Protokol Opsional pada Konvenan tentang Hak Ekonomi, Sosial, dan Budaya. Konvenan Internasional tentang HAk Sipil dan Politik serta 
Protokol Opsional pada Konvenan Internasioanl tentang Hak Sipil dan Politik mulai berlaku pada tanggal 23 Maret 1976. Kemudian dengan masuknya Indonesia kedalam organisasi dunia, dan sebagai Negara yang mengaku sebagai Negara hokum yang sejak kelahirannya pada tahun 1945 menjunjung tinggi HAM. Maka, Indonesia meratifikasi Kovenan Internasional Tentang Hak-Hak Sipil Dan Politik dalam Undang-Undang Nomor 12 Tahun 2005.

Pokok-pokok Isi Kovenan Internasional tentang Hak-hak Sipil dan Politik yang ratifikasinya disahkan melalui UU Nomor 12 Tahun 2005 antara lain mengukuhkan pokok-pokok HAM di bidang sipil dan politik yang tercantum dalam DUHAM sehingga menjadi ketentuan-ketentuan yang mengikat secara hukum dan penjabarannya mencakup pokok-pokok lain yang terkait. Kovenan tersebut terdiri dari pembukaan dan PasalPasal yang mencakup 6 bab dan 53 pasal. Kedua Kovenan tersebut mengingatkan negara-negara akan kewajibannya, menurut Piagam PBB, untuk memajukan dan melindungi HAM, mengingatkan individu akan tanggung jawabnya untuk bekerja keras bagi pemajuan dan penaatan HAM yang diatur dalam Kovenan ini dalam kaitannya dengan individu lain dan masyarakatnya, dan mengakui bahwa, sesuai dengan DUHAM, citacita umat manusia untuk menikmati kebebasan sipil dan politik serta kebebasan dari rasa takut dan kemiskinan hanya dapat tercapai apabila telah tercipta kondisi bagi setiap orang untuk dapat menikmati hak-hak sipil dan politiknya maupun hak-hak ekonomi, sosial dan budayanya. 
Pasal 1 menyatakan bahwa semua rakyat mempunyai hak untuk menentukan nasibnya sendiri dan meyerukan kepada semua Negara. Pada pasal tersebut jika dikaitkan dengan Pekerja Indoneisia memberikan hak kepada masyarakat Indonesia untuk menentukan nasibnya sendiri menjadi pekerja Indonesia, Negara dilarang untuk menghalangi hal tersebut. Termasuk diantaranya adlaah pekerja Indoneisa yang berada dan akan pergi keluar Negeri.

Kemudian Pasal 6 sampai dengan Pasal 27 menetapkan bahwa setiap manusia mempunyai hak hidup, bahwa hak ini dilindungi oleh hukum, dan bahwa tidak seorangpun dapat dirampas hak hidupnya secara sewenang-wenang (Pasal 6); bahwa tidak seorang pun boleh dikenai siksaan, perlakuan atau penghukuman yang kejam, tidak manusiawi, atau merendahkan martabat (Pasal 7); bahwa tidak seorang pun boleh diperbudak, bahwa perbudakan dan perdagangan budak dilarang, dan bahwa tidak seorang pun boleh diperhamba, atau diharuskan melakukan kerja paksa atau kerja wajib (Pasal 8); dan bahwa tidak seorang pun boleh dipenjarakan hanya atas dasar ketidakmampuannya memenuhi kewajiban kontraktualnya (Pasal 11). Pasal-pasal tersebut yang maktub dalam konvenan tersebut menyatakan bahwa pekerja Indonesia yang merupakan subyek dari Konvenan tersebut wajib dilindungi dari perlakuan kejam dan sebagainya sesuai dengan pasal tersebut yang kemudian wajib diimplikasikan oleh Indonesia sebagai bukti bahwa Indonesia ikut kedalam organisasi dunia. 
Selanjutnya Kovenan menetapkan kebebasan setiap orang yang berada secara sah di wilayah suatu negara untuk berpindah tempat dan memilih tempat tinggalnya di wilayah itu, untuk meninggalkan negara manapun termasuk negara sendiri, dan bahwa tidak seorang pun dapat secara sewenang-wenang dirampas haknya untuk memasuki negaranya sendiri (Pasal 12). Hal ini menjelaskan Pekerja Indonesia berhak untuk berpindah tempat sebagai upaya mencari uang.

9. Undang-Undang Nomor 14 Tahun 2009 tentang Pengesahan Protokol untuk Mencegah, Menindak, dan Menghukum Perdagangan Orang, Terutama Perempuan dan Anak-Anak, Melengkapi Konvensi Perserikatan Bangsa-Bangsa Menentang Tindak Pidana Transnasional Yang Terorganisasi (Protocol To Prevent, Suppress And Punish Trafficking In Persons, Especially Women And Children, Supplementing The United Nations Convention Against Transnational Organized Crime)

Undang-Undang Nomor 14 Tahun 2009 tentang Protokol Untuk Mencegah, Menindak, Dan Menghukum Perdagangan Orang, Terutama Perempuan Dan Anak-Anak, Melengkapi Konvensi Perserikatan BangsaBangsa Menentang Tindak Pidana Transnasional Yang Terorganisasi, merupakan salah satu bentuk dukungan Indonesia dalam pemberantasan tindak pidana perdagangan orang. Hal ini juga menjadi cerminan dari komitmen Indonesia sebagai negara anggota Perserikatan BangsaBangsa dalam menjaga ketertiban dunia.

Menurut Pasal 2 huruf a tujuan dari Protokol ini adalah untuk mencegah dan memberantas perdagangan orang, dengan memberikan perhatian khusus kepada perempuan dan anak-anak. Maksud dari istilah "anak" adalah berarti setiap orang yang berusia di bawah delapan belas tahun (Pasal 3 huruf d). 
Pasal 3 huruf a menyatakan: "Perdagangan orang berarti perekrutan, pengangkutan, pengiriman, penampungan, atau penerimaan orang-orang, dengan ancaman atau penggunaan kekerasan atau bentuk lain dari paksaan, penculikan, penipuan, penyesatan, penyalahgunaan kekuasaan atau keadaan rentan atau pemberian atau penerimaan pembayaran atau keuntungan untuk mendapatkan persetujuan dari seseorang yang memiliki kekuasaan atas orang lain, untuk tujuan eksploitasi. Eksploitasi meliputi, sekurang-kurangnya, eksploitasi dalam pelacuran seseorang atau bentuk eksploitasi seksual lainnya, kerja atau pelayanan paksa, perbudakan atau praktek-praktek serupa dengan perbudakan, penghambaan atau pengambilan organ-organ.

10. Undang-Undang Nomor 15 Tahun 2009 tentang Pengesahan Protokol untuk Menentang Penyelundupan Migran Melalui Darat, Laut, Dan Udara, Melengkapi Konvensi Perserikatan Bangsa-Bangsa Menentang Tindak Pidana Transnasional Yang Terorganisasi (Protocol Against The Smuggling of Migrants by Land, Sea and Air, Supplementing the United Nations Convention Against Transnational Organized Crime)

Indonesia sebagai negara kepulauan rentan dengan kasus penyelundupan migran baik melalui darat, laut maupun udara. Sejak tahun 2009 Indonesia telah meratifikasi Protokol Menentang Penyelundupan Migran Melalui Darat, Laut, dan Udara, Melengkapi Konvensi Perserikatan Bangsa-Bangsa Menentang Tindak Pidana Transnasional Yang terorganisasi. Tujuan utama dari protokol ini adalah untuk mencegah dan memberantas penyelundupan para migran serta melindungi hak-hak para migran yang diselundupkan. 
Pasal 3 huruf a menyatakan: "Penyelundupan para migran berarti pengadaan, untuk memperoleh, secara langsung atau tidak lagsung, suatu keuntungan keuangan atau keuntungan material lainnya, masuknya seseorang secara ilegal dalam suatu Negara Pihak, yang orang tersebut bukan warga negara atau penduduk tetap". Ketentuan lainnya mengenai "masuk secara ilegal" berarti melintasi batas-batas dengan tidak mematuhi persyaratan-persyaratan yang diperlukan untuk masuk secara sah ke dalam Negara penerima.

Menurut Pasal 3 huruf $\mathrm{c}$, dokumen perjalan atau identitas palsu berarti setiap dokumen perjalanan atau dokumen identitas: (i) Yang telah secara palsu dibuat atau diubah secara material oleh setiap orang selain seseorang atau agen yang secara sah diberikan kewenangan untuk membuat atau menerbitkan dokumen perjalanan atau dokumen identitas atas nama suatu Negara; (ii) Yang telah diterbitkan secara tidak patut atau diperoleh melalui bujukan, korupsi, di bawah paksaan, atau cara lain yang melawan hukum; atau (iii) Yang telah digunakan oleh seseorang selain pemegang yang berhak.

11. Undang-Undang Nomor 6 Tahun 2012 tentang Pengesahan Konvensi Internasional mengenai Perlindungan Hak-hak Seluruh Pekerja Migran dan Anggota Keluarganya (International Convention on the Protection of the Rights of All Migrant Workers and Members of Their Families)

Pasal 1 Konvensi ILO 1990 yang telah diratifikasi melalui UU Nomor 6 Tahun 2012 berlaku bagi seluruh pekerja migran dan anggota keluarga tanpa membedakan jenis kelamin, ras, warna kulit, bahasa, agama atau kepercayaan, pendapat politik atau lain-lain kebangsaan, 
asal-usul etnis atau sosial, kewarganegaraan, usia, kedudukan ekonomi, kekayaan, status perkawinan, status kelahiran.

Selain Pekerja migran, Konvensi ini juga mengatur mengenai pekerja lintas batas, pekerja musiman, pelaut, pekerja pada instalasi lepas pantai, pekerja keliling, pekerja proyek, pekerja dengan pekerjaan tertentu baik untuk jangka waktu maupun negara tujuan tertentu, serta pekerja mandiri (Pasal 2 Konvensi ILO 1990).

Tujuan perlindungan yang diberikan melalui Konvensi ini tidak saja hanya terbatas kepada pekerja migran, nemun juga kepada anggota keluarga pekerja migran seperti tercantum dalam Pasal 4 Konvensi ILO 1990. Anggota keluarga pekerja dalam konvensi ini mengacu pada orangorang yang kawin dengan pekerja migran atau mempunyai hubungan dengan pekerja migran menurut hukum yang berlaku berakibat sama dengan perkawinan, dan juga anak-anak pekerja migran yang menjadi tanggungan dan orang-orang lain yang menjadi tanggungan mereka yang diakui sebagai anggota keluarga menurut hukum yang berlaku.

Hak pekerja migran sebagai manusia, tidak dapat dibatasi dan sangat dijunjung tinggi dalam konvensi ILO 1990 dimana hak-hak pekerja migran sangat jelas dan lengkap dinyatakan dalam pasal-pasal konvensi seperti hak memasuki dan tinggal dinegara asal, juga bebas untuk meninggalkan negara manapun, termasuk negara asal pekerja migran (Pasal 8 Konvensi ILO 1990), tidak diperbolehkan untuk dijadikan sasaran penyiksaan atau perlakuan atau penghukuman yang kejam, tidak manusiawi dan merendahkan martabat (Pasal 10 Konvensi ILO 1990), 
tidak boleh diperbudak atau diperhambakan, tidak diwajibkan untuk melakukan kerja paksa (Pasal 11 Konvensi ILO 1990), memiliki kebebasan untuk menjalankan agama dan kepercayaan (Pasal 12 Konvensi ILO 1990), tidak dapat diganggu dalam hal urusan pribadi, keluarga, rumah tangga, korespondensi atau komunikasi lain atau secara tidak sah diserang kehormatan dan nama baiknya, memiliki hak atas perlindungan hukum terhadap gangguan atau serangan (Pasal 14 Konvensi ILO 1990).

Pekerja Migran dan anggota keluarga juga tidak boleh dipenjara semata-mata atas dasar kegagalan memenuhi perjanjian, tidak boleh dirampas ak atas izin tinggal atau izin kerja, atau diusir semata-mata atas dasar kegagalan memenuhi suatu kewajiban yang muncul dari perjanjian kerja (Pasal 20 Konvensi ILO 1990).

Dalam konvensi ini juga mengatur larangan kepada setiap orang untuk menyita, menghancurkan atau mencoba menghancurkan dokumen identitas, dokumen yang memberi izin masuk atau tinggal, bertempat tinggal atau dokumen penting lain seperti paspor atau dokumen setara milik pekerja migran atau anggota keluarga yang diperlukan di wilayah nasional atau izin kerja. Tindakan tersebut dikategorikan sebagai tindakan yang melawan hukum (Pasal 21 Konvensi ILO 1990).

Perlakuan yang sama diberikan dalam konvensi ini kepada pekerja migran yang berkaitan dengan akses pada lembaga dan pelayanan pendidikan, bimbingan kejuruan dan pelayanan penempatan, pelatihan kejuruan, akses perumahan dan perlindungan terhadap eksploitasi dalam 
hal penyewaan, pelayanan sosial dan kesehatan, akses pada perusahaan-perusahaan koperasi (Pasal 43 Konvensi ILO 1990). Hak-hak yang dinyatakan dalam konvensi ILO ini menjadi bagian dari perlindungan yang diberikan bagi pekerja migran dan anggota keluarganya.

Peraturan yang berasal dari hukum hasil ratifikasi terkait penempatan dan perlindungan TKI secara singkat dipaparkan pada tabel berikut:

Tabel 4.6 Kajian Peraturan Perundang-Undangan terkait Penempatan dan Perlindungan TKI di Luar Negeri dari Hukum Hasil Ratifikasi

\begin{tabular}{|c|c|c|}
\hline No. & Peraturan & Tentang \\
\hline 1. & UU No. 1 Tahun 1982 & $\begin{array}{l}\text { Pengesahan Konvensi Wina mengenai } \\
\text { Hubungan Diplomatik Beserta Protokol } \\
\text { Opsionalnya Mengenai Hal Memperoleh } \\
\text { Kewarganegaraan (Vienna Convention on } \\
\text { Diplomatic Relations and Optional Protocol } \\
\text { to the Vienna Convention on Diplomatic } \\
\text { Relations Concerning Acquisition of } \\
\text { Nationality, } 1961 \text { ) dan Pengesahan } \\
\text { Konvensi Wina mengenai Hubungan } \\
\text { Konsuler Beserta Protokol Opsionalnya } \\
\text { Mengenai Hal Memperoleh } \\
\text { Kewarganegaraan (Vienna Convention on } \\
\text { Consular Relations and Optional Protocol to } \\
\text { the Vienna Convention on Consular Relation } \\
\text { Concerning Acquisition of Nationality, 1963) }\end{array}$ \\
\hline 2. & UU No. 17 Tahun 1984 & $\begin{array}{l}\text { Pengesahan Konvensi mengenai } \\
\text { Penghapusan Segala Bentuk Diskriminasi } \\
\text { terhadap Wanita (Convention on the } \\
\text { Ellimination of All Forms of Discrimination } \\
\text { Against Women) }\end{array}$ \\
\hline 3. & UU No. 5 Tahun 1998 & $\begin{array}{l}\text { Pengesahan Konvensi menentang } \\
\text { Penyiksaan dan Perlakuan an atau } \\
\text { Penghukuman Lain yang Kejam, Tidak } \\
\text { Manusiawi atau Merendahkan Martabat } \\
\text { Manusia (Convention against Torture and } \\
\text { Other Cruel, Inhuman or Degrading } \\
\text { Treatment or Punishment) }\end{array}$ \\
\hline 4. & UU No.19 Tahun 1999 & $\begin{array}{l}\text { Pengesahan Konvensi ILO mengenai } \\
\text { Penghapusan Kerja Paksa (ILO Convention } \\
\text { No. } 105 \text { Concerning the Abolition of Forced } \\
\text { Labour) }\end{array}$ \\
\hline
\end{tabular}




\begin{tabular}{|c|c|c|}
\hline 5. & UU No. 20 Tahun 1999 & $\begin{array}{l}\text { Pengesahan Konvensi ILO mengenai Usia } \\
\text { Minimum untuk Diperbolehkan Bekerja (ILO } \\
\text { Convention No. } 138 \text { Concerning Minimum } \\
\text { Age for Admission to Employment) }\end{array}$ \\
\hline 6. & UU No. 21 Tahun 1999 & $\begin{array}{l}\text { Pengesahan Konvensi ILO mengenai } \\
\text { Diskriminasi dalam Pekerjaan dan Jabatan } \\
\text { (ILO Convention No. } 111 \text { Concerning } \\
\text { Discrimination in Respect of Employment } \\
\text { and Occupation) }\end{array}$ \\
\hline 7. & UU No. 11 Tahun 2005 & $\begin{array}{l}\text { Pengesahan Konvenan Internasional } \\
\text { tentang Hak-Hak Ekonomi, Sosial dan } \\
\text { Budaya (International Convenant on } \\
\text { Economic, Social and Cultural Rights) }\end{array}$ \\
\hline 8. & UU No. 12 Tahun 2005 & $\begin{array}{l}\text { Pengesahan Konvenan } \text { Internasional } \\
\text { tentang Hak-Hak Sipil dan Politik } \\
\text { (International Convenant on Civil and } \\
\text { Political Rights) }\end{array}$ \\
\hline 9. & UU No. 14 Tahun 2009 & $\begin{array}{l}\text { Pengesahan Protokol untuk Mencegah, } \\
\text { Menindak, dan Menghukum Perdagangan } \\
\text { Orang, Terutama Perempuan dan Anak- } \\
\text { Anak, Melengkapi Konvensi Perserikatan } \\
\text { Bangsa-Bangsa Menentang Tindak Pidana } \\
\text { Transnasional Yang Terorganisasi (Protocol } \\
\text { To Prevent, Suppress And Punish Trafficking } \\
\text { In Persons, Especially Women And Children, } \\
\text { Supplementing The United Nations } \\
\text { Convention Against Transnational Organized } \\
\text { Crime) }\end{array}$ \\
\hline 10. & UU No. 15 Tahun 2009 & $\begin{array}{l}\text { Pengesahan Protokol untuk Menentang } \\
\text { Penyelundupan Migran Melalui Darat, Laut, } \\
\text { Dan Udara, Melengkapi Konvensi } \\
\text { Perserikatan Bangsa-Bangsa Menentang } \\
\text { Tindak Pidana Transnasional Yang } \\
\text { Terorganisasi (Protocol Against The } \\
\text { Smuggling of Migrants by Land, Sea and Air, } \\
\text { Supplementing the United Nations } \\
\text { Convention Against Transnational Organized } \\
\text { Crime) }\end{array}$ \\
\hline 11. & UU No. 6 Tahun 2012 & $\begin{array}{l}\text { Pengesahan Konvensi Internasional } \\
\text { mengenai Perlindungan Hak-hak Seluruh } \\
\text { Pekerja Migran dan Anggota Keluarganya } \\
\text { (International Convention on the Protection } \\
\text { of the Rights of All Migrant Workers and } \\
\text { Members of Their Families) }\end{array}$ \\
\hline
\end{tabular}

Peraturan terkait pada tabel 4.6 diatas juga merupakan hasil kompilasi dari Naskah Akademik Rancangan Undang-Undang Perlindungan Pekerja Indonesia di Luar Negeri (NA RUU PPILN) versi 7 Juni 2012 yang kemudian diperbaharui kembali dalam NA RUU PPILN 
versi 27 Mei 2015 yang dipisahkan dari hukum nasional ke dalam kategori hukum hasil ratifikasi. Berdasarkan hasil sinkronisasi ini pada tabel $4.6 \mathrm{di}$ atas menunjukkan 11 peraturan terkait yang terdiri atas 8 konvensi PBB dan 3 konvensi ILO. Salah satu diantara peraturan terkait tersebut adalah Konvensi Internasional Perlindungan Hak Pekerja Migran.

Walaupun konvensi ILO yang disebutkan sebagai peraturan terkait pada tabel 4.6 di atas hanya 3 jenis, namun menurut Ramiany Sinaga, Kepala Biro Hukum dan Humas BNP2TKI dalam wawancaranya dengan peneliti menyatakan bahwa Indonesia telah terikat pada 8 konvensi ILO terkait HAM yakni:

"Konvensi terkait penghapusan pekerja anak yakni Konvensi ILO No. 138 dan 182, kemudian kebebasan untuk berserikat pada Konvensi ILO No. 87 dan 98, selanjutnya terkait penghapusan diskriminasi dalam pekerjaan pada Konvensi ILO No. 100 dan 111, terakhir konvensi terkait kerja paksa pada konvensi ILO No. 29 dan $105 " .45$

Pendapat di atas sejalan dengan kompilasi konvensi ILO tentang prinsip fundamental dan hak di tempat kerja yang merupakan bagian dari naskah akademik RUU PPILN versi 7 Juni 2012 sebagai berikut:

Tabel 4.7 Konvensi ILO tentang Prinsip Fundamental dan Hak di Tempat Kerja

\begin{tabular}{|l|l|c|}
\hline No & $\begin{array}{c}\text { Prinsip Fundamental dan } \\
\text { Hak di Tempat Kerja }\end{array}$ & \multicolumn{1}{|c|}{ Konvensi yang Relevan } \\
\hline 1 & $\begin{array}{l}\text { Kebebasan untuk berserikat } \\
\text { dan bernegosiasi secara } \\
\text { kolektif }\end{array}$ & $\begin{array}{l}\text { Konvensi ILO No. 87 Tahun 1948 } \\
\text { tentang Kebebasan Berserikat } \\
\text { dan Hak untuk Berorganisasi } \\
\text { Konvensi ILO No. 98 Tahun 1949 } \\
\text { tentang Hak untuk Berorganisasi } \\
\text { dan Bernegosiasi Secara Kolektif }\end{array}$ \\
\hline 2 & $\begin{array}{l}\text { Penghapusan segala bentuk } \\
\text { kerja paksa atau kerja yang }\end{array}$ & $\begin{array}{l}\text { Konvensi ILO No. 29 Tahun 1930 } \\
\text { tentang Kerja Paksa }\end{array}$ \\
\hline
\end{tabular}

${ }^{45}$ Ibid. 


\begin{tabular}{|l|l|l|}
\hline & diwajibkan & $\begin{array}{l}\text { Konvensi ILO No. 105 Tahun } \\
1957 \text { tentang Penghapusan Kerja } \\
\text { Paksa }\end{array}$ \\
\hline 3 & Penghapusan pekerja anak & $\begin{array}{l}\text { Konvensi ILO No. 138 Tahun } \\
1973 \text { tentang Usia Minimum } \\
\text { Konvensi ILO No. 182 Tahun } \\
1999 \text { tentang Bentuk-Bentuk } \\
\text { Pekerjaan Terburuk Anak }\end{array}$ \\
\hline \multirow{4}{*}{$\begin{array}{l}\text { Kenvensi ILO No. 100 Tahun } \\
1951 \text { tentang Upah yang Sama }\end{array}$} \\
& Penghapusan diskriminasi & $\begin{array}{l}\text { Konvensi ILO No. 111 Tahun } \\
1958 \text { tentang Diskriminasi dalam } \\
\text { Pekerjaan dan Jabatan }\end{array}$ \\
\hline
\end{tabular}

Empat (4) area prinsip fundamental dan hak pekerja di tempat kerja yang tertuang dalam Deklarasi ILO tentang Prinsip Fundamental dan Hak di Tempat Kerja, berlaku untuk semua pekerja tanpa memandang kebangsaan dan status sebagai pekerja migran. Berikut adalah hak-hak pekerja migran sesuai dengan prinsip fundamental.

Tabel 4.8 Hak Pekerja Migran Sesuai Prinsip Fundamental

\begin{tabular}{|c|c|c|}
\hline No. & Prinsip Fundamental & Hak Pekerja Migran \\
\hline 1. & $\begin{array}{l}\text { Kebebasan untuk } \\
\text { berserikat dan } \\
\text { bernegosiasi secara } \\
\text { kolektif }\end{array}$ & $\begin{array}{l}\text { Membentuk dan bergabung dalam } \\
\text { serikat pekerja migran } \\
\text { Terlibat dalam negosiasi kolektif } \\
\text { terkait dengan hal-hal yang } \\
\text { mempengaruhi kondisi kerja } \\
\text { pekerjaan } \\
\text { Memilih perwakilan } \\
\text { Menggunakan sarana/media untuk } \\
\text { arbitrasi dan perdamaian dalam } \\
\text { penyelesaian perselisihan } \\
\text { Mogok } \\
\text { Hak atas kebebasan dan keamanan } \\
\text { pribadi } \\
\text { Bebas dari penangkapan dan } \\
\text { penahanan semena-mena } \\
\text { Kebebasan untuk berpendapat dan } \\
\text { berekspersi dan secara khusus bebas } \\
\text { untuk mempertahankan pendapat } \\
\text { tanpa campur tangan } \\
\text { Hak untuk mencari, menerima dan }\end{array}$ \\
\hline
\end{tabular}




\begin{tabular}{|c|c|c|}
\hline & & $\begin{array}{l}\text { memberi informasi, serta gagasan } \\
\text { melalui media manapun tanpa } \\
\text { pembatasan hak untuk berkumpul } \\
\text { * Hak untuk diadili secara adil oleh } \\
\text { pengadilan yang independen dan } \\
\text { tidak memihak } \\
\text { * Hak atas perlindungan hak milik } \\
\text { serikat pekerja }\end{array}$ \\
\hline 2. & $\begin{array}{l}\text { Penghapusan segala } \\
\text { bentuk kerja paksa } \\
\text { atau kerja yang } \\
\text { diwajibkan }\end{array}$ & $\begin{array}{l}\text { Bekerja harus didasarkan atas pilihan dan } \\
\text { insentif, bukan didasarkan atas paksaan } \\
\text { atau ancaman. Implikasinya, di antaranya: } \\
\text { Pekerja migran tidak boleh dipaksa } \\
\text { bekerja di bawah ancaman hukuman } \\
\text { * Pekerja migran secara fisik tidak boleh } \\
\text { dikurung } \\
\text { Pekerja migran dapat mengakhiri atau } \\
\text { diakhiri pekerjaannya sesuai dengan } \\
\text { ketentuan hukum nasional } \\
\text { - Pendisiplinan terhadap pekerja migran } \\
\text { yang melanggar aturan di tempat kerja } \\
\text { tidak boleh dilakukan dalam bentuk } \\
\text { kerja paksa } \\
\text { * Pekerja migran yang terlibat dalam } \\
\text { kegiatan mogok yang sah menurut } \\
\text { undang-undang tidak boleh diminta } \\
\text { bekerja secara paksa }\end{array}$ \\
\hline 3. & $\begin{array}{l}\text { Penghapusan pekerja } \\
\text { anak }\end{array}$ & $\begin{array}{l}\text { * Anak dibawah usia } 15 \text { tahun tidak } \\
\text { diperbolehkan bekerja. Bila terpaksa } \\
\text { bekerja, jam kerja tidak boleh lebih } \\
\text { dari jam usai sekolah } \\
\text { * Pekerjaan berbahaya tidak boleh } \\
\text { dilakukan oleh anak-anak di bawah } \\
\text { usia } 18 \text { tahun } \\
\text { * Untuk memonitor usia anak, negara } \\
\text { dituntut untuk membuat sistem } \\
\text { registrasi kelahiran } \\
\text { * Hak anak-anak pekerja migran untuk } \\
\text { mendapatkan akte kelahiran } \\
\text { * Hak bagi anak pekerja migran atau } \\
\text { pekerja migran anak untuk bebas dari } \\
\text { bentuk-bentuk pekerjaan terburuk } \\
\text { anak }\end{array}$ \\
\hline 4. & $\begin{array}{l}\text { Penghapusan } \\
\text { diskriminasi dalam } \\
\text { pekerjaan dan jabatan }\end{array}$ & $\begin{array}{l}\text { Larangan diskriminasi berdasarkan seks, } \\
\text { ras, agama, etnis, status perkawinan, dll }\end{array}$ \\
\hline
\end{tabular}

Sumber: Naskah Akademik RUU PPILN versi 7 Juni 2012 
Tabel di atas telah menjabarkan 4 prinsip fundamental antara lain: (1) kebebasan untuk berserikat dan bernegosiasi secara kolektif; (2) penghapusan segala bentuk kerja paksa atau kerja yang diwajibkan; (3) penghapusan pekerja anak dan (4) penghapusan diskriminasi dalam pekerjaan dan jabatan. Keempat prinsip fundamental ini memiliki 8 konvensi ILO terakit yang secara ringkas memiliki hak-hak sebagaimana telah dipaparkan pada tabel sebelah kanan.

Berdasarkan penjelasan di atas maka dapat disimpulkan bahwa hasil evaluasi UU No. 39 Tahun 2004 telah mengidentifikasi permasalahan terkait pasal-pasal dalam UU yang beriorientasi pada pengaturan penempatan dibandingkan perlindungan, peran dan koordinasi antar lembaga pemerintah di pusat maupun daerah, serta kewajiban perlindungan yang masih dibebankan kepada pihak swasta (PPTKIS) daripada pemerintah. Selanjutnya hasil identifikasi terhadap muatan pasal dan ayat dalam UU No. 39 Tahun 2004 terdiri atas lima kluster, antara lain: (1) ketentuan atau muatan yang tidak melindungi atau merugikan TKI, (2) ketenuan atau muatan yang tidak jelas, kabur arti dan implikasinya, (3) ketentuan atau muatan yang tidak lengkap, (4) ketentuan atau muatan saling bertentangan dan inkonsisten, dan (5) ketentuan atau muatan yang menimbulkan konflik kelembagaan.

Dalam evaluasi ini juga perwakilan Kementerian Ketenagakerjaan RI menekankan perlunya pendalaman substansi konvensi untuk menyesuaikan dengan kebutuhan Indonesia agar tujuan untuk memberikan perlindungan bagi seluruh pekerja Indonesia di luar negeri 
dapa tercapai. Kepala Biro Hukum dan Humas BNP2TKI juga menyatakan bahwa masih adanya hambatan-hambatan dalam pelaksanaan UU No. 39 Tahun 2004, utamanya keterbatasan jangkauan dari UU ini kepada sektor formal/profesional, sedangkan sektor informal masih lebih dominan diakomodir dalam UU.

Kajian peraturan perundang-undangan terkait dengan penempatan dan perlindungan TKI di luar negeri dengan menggunakan taraf sinkronisasi vertikal dan horizontal. Kajian ini terbagi ke dalam dua kategori yakni hukum nasional dan hukum hasil ratifikasi. Peraturan terkait dari hukum nasional terdiri atas 16 jenis Undang-Undang dan 3 jenis Permenaker RI. Sedangkan peraturan terkait hukum hasil ratifikasi terdiri atas 8 konvensi PBB dan 3 konvensi ILO. Salah satu diantaranya merupakan Konvensi Internasional Perlindungan Hak Pekerja Migran. Selain 3 konvensi ILO yang masuk dalam peraturan terkait, masih ada 5 konvensi ILO lainnya yang menurut Kepala Biro Hukum dan Humas BNP2TKI termasuk dalam prinsip fundamental yang terbagi ke dalam 4 kategori yakni kebebasan berserikat, penghapusan kerja paksa, penghapusan kerja anak dan penghapusan diskriminasi dalam pekerjaan.

\section{B. Adopsi Substansi Konvensi Internasional Perlindungan Hak} Pekerja Migran ke dalam Undang-Undang No. 39 Tahun 2004

Konvensi Internasional Perlindungan Hak Pekerja Migran merupakan salah satu peraturan perundang-undangan terkait penempatan dan perlindungan TKI yang berasal dari hukum hasil ratifikasi. Konvensi tersebut telah diratifikasi melalui Undang-Undang 
Nomor 6 Tahun 2012. Penjelasan teknis mengenai harmonisasi Konvensi Internasional tersebut dengan Undang-Undang telah dijelaskan pada bagian sebelumnya. Pada bagian ini, penulis akan memfokuskan pada substansi konvensi yang diadopsi ke dalam Undang-Undang Nomor 39 Tahun 2004 melalui RUU Perubahan UU No. 39 Tahun 2004.

Perjalanan proses adopsi substansi konvensi internasional telah tercatat pada penelusuran awal peneliti yang mengutip informasi dari LSM Migrant Care yang menyatakan bahwa revisi UU No. 39 Tahun 2004 telah masuk sebagai agenda program legislasi nasional (prolegnas) DPR RI pada November 2010, kemudian 12 April 2012 Konvensi Internasional Perlindungan Hak Pekerja Migran disahkan dalam rapat paripurna oleh DPR RI, dilanjutkan pada 23 Mei 2012 dilakukan pengharmonisasian, pembulatan dan pemantapan konsepsi Rancangan Undang-Undang Perlindungan Pekerja Indonesia di Luar Negeri (PPILN), akhirnya 5 Juli 2012 DPR RI mengadakan sidang paripurna DPR RI mengesahkan RUU revisi UU PPILN menjadi RUU inisiatif DPR RI. Proses terus berlanjut hingga 8 April 2013, rapat antara panitia kerja (panja) RUU PPILN dengan pemerintah membahas judul RUU tetapi tidak ada kesepakatan. Revisi undang-undang ini belum disepakati hingga berakhirnya masa bakti DPR RI 2009-2014. Setelah pemilihan legislatif tahun 2014 dan terpilihnya anggota DPR RI masa bakti 2014-2019 belum ada lagi pembahasan RUU antara pemerintah dan dewan.

Dalam proses pembahasan RUU Perubahan UU No. 39 Tahun 2004 pada masa bakti DPR RI 2009-2014, RUU Perubahan masih 
dianggap belum mengadopsi konvensi internasional perlindungan hak pekerja migran yang telah diratifikasi. Hal ini disampaikan Koordinator Jaringan Advokasi Revisi UU PPTKLN, Nurus S. Mufidah dikutip dari hukumonline.com yang menyebutkan secara umum isi RUU PPTKLN rumusan pemerintah tak jauh beda dengan versi DPR. Kedua RUU itu dinilai tak peka terhadap aspek perlindungan untuk TKI.

"RUU Penempatan dan Perlindungan Tenaga Kerja Indonesia di Luar Negeri (PPTKLN) yang dirumuskan pemerintah dan sudah diserahkan ke DPR dinilai masih kurang memperhatikan aspek perlindungan TKI. Padahal, sejumlah peraturan, salah satunya Konvensi Perlindungan Pekerja Migran dan Keluarganya -yang sudah diratifikasi oleh pemerintah- menekankan pentingnya perlindungan bagi TKI dan keluarganya" ${ }^{\text {46 }}$

Dari segi judul RUU, Fida menyatakan bahwa antara RUU PPTKLN dengan UU PPTKILN masih sama. Padahal, dalam berbagai kesempatan, Fida menyebut koalisi selalu mengingatkan pemerintah bahwa UU PPTKLN kurang menekankan pada aspek perlindungan untuk TKI. Alihalih. Mengutamakan perlindungan, UU PPTKLN dirasa menjadikan TKI sebagai komoditas. Ujungnya, TKI berpotensi besar terus-terusan menjadi korban. ${ }^{47}$

Fida juga mengingatkan bahwa Indonesia telah menjadi negara pihak dalam konvensi internasional perlindungan hak pekerja migran. Sehingga menjadi kewajiban bagi pemerintah (eksekutif dan legislatif) untuk memasukkan konvensi yang sudah diratifikasi dalam pertimbangan pada RUU perubahan.

\footnotetext{
46 Hukum Online, (2013), RUU PPTKLN Masih Abaikan Perlindungan TKI http://www.hukumonline.com/berita/baca/lt512c88d35a24e/ruupptklnmasihabaikanperlind ungantki, diakses pada 3 Juni 2017. ${ }^{47}$ lbid.
} 
"Indonesia telah meratifikasi Konvensi PBB tentang Perlindungan Pekerja Migran dan Anggota Keluarganya. Sayangnya dalam RUU versi pemerintah hal itu tak dimasukan dalam konsideran, baik dalam konsideran menimbang maupun mengingat. Pemerintah mestinya menjadikan konvensi ini sebagai dasar dalam merevisi UU PPTKLN. Karena salah satu kewajiban pemerintah paska meratifikasi sebuah instrumen HAM internasional adalah melakukan harmonisasi hukum nasional dengan konvensi tersebut". ${ }^{48}$

Di kesempatan yang sama, perwakilan dari Dirjen Binapenta Kemenakertrans RI, Reyna Usman menyatakan tidak setuju atas pernyataan yang menyebut konvensi Perlindungan Pekerja Migran tak menjadi pertimbangan dalam RUU PPTKLN versi pemerintah. Menurutnya, dalam DIM yang disampaikan pemerintah kepada DPR awal bulan ini, sudah mengakomodir kepentingan berbagai pihak. ${ }^{49}$

Memasuki masa bakti DPR RI periode 2014-2019, RUU Perubahan UU No. 39 Tahun 2004 kembali masuk ke dalam program legislasi nasional (prolegnas). WikiDPR mendokumentasikan bahwa pada 23 April 2015, Komisi IX DPR RI mengadakan rapat dengar pendapat (RDP) dengan Deputi Perundang-Undangan (DUU) DPR RI terkait pembahasan RUU Perlindungan Tenaga Kerja Indonesia di Luar Negeri (RUU Perlindungan $\mathrm{TKI}) .{ }^{50}$ Dari rangkuman yang dihimpun oleh WikiDPR belum terlihat adanya perhatian yang diberikan pada adopsi substansi konvensi dengan RUU Perubahan UU No. 39 Tahun 2004.

\footnotetext{
${ }^{48}$ Ibid.

49 lbid.

${ }^{50}$ WikiDPR, 2015, RUU Perlindungan TKI di Luar Negeri - Rapat Komisi 9 dengan Deputi Perundang-Undangan DPR-RI - http://wikidpr.org/rangkuman/ruu-perlindungan-tki-diluar-negeri---rapat-komisi-9-dengan-deputi-perundang-undangan-dpr-ri, diakses pada 5 Juni 2017.
} 
Selanjutnya, WikiDPR mendokumentasikan juga rapat pada 26 Agustus 2015, Komisi IX melaksanakan Rapat Panja Tenaga Kerja Indonesia (TKI) dengan agenda penyerahan hasil Panja TKI berupa RUU Perlindungan Pekerja Indonesia di Luar Negeri (PPILN) ${ }^{51}$ Dari rangkuman yang dihimpun oleh WikiDPR rapat ini juga belum menyinggung tentang harmonisasi konvensi internasional perlindungan hak pekerja migran. Beberapa pernyataan yang menyebutkan kata 'harmonisasi', namun tidak spesifik maksudnya antara lain disampaikan Rieke Diah Pitaloka dari Fraksi Partai Demokrasi Indonesia Perjuangan (PDIP) dan Okky Asokawati dari Fraksi Partai Persatuan Pembangunan (PPP).

Rieke Diah Pitaloka menyampaikan bahwa PDIP setuju dengan draf UU TKI di Luar negeri, sekaligus menerima hasil kerja Panja RUU PPILN. Rieke berharap RUU ini segera dilakukan harmonisasi, sehingga minggu depan bias dibawa ke Paripurna. Sedangkan, Okky Asokawati menyatakan telah menyetujui draf RUU PPILN dan meminta segera diberikan ke Baleg lalu Pansus. Okky meminta agar anggota Komisi 9 di Baleg dapat berusaha mempercepat harmonisasinya. Okky mengapresiasi kinerja Panja RUU PPILN dan meminta agar diinfokan ketika sudah masuk ke Baleg. Sehingga kesimpulan rapat panja RUU PPILN menyatakan bahwa anggota Fraksi yang hadir meminta agar mendalami draf RUU PPILN ini untuk secepatnya diharmonisasi dan langsung melakukan kunjungan kerja. ${ }^{52}$

\footnotetext{
${ }^{51}$ WikiDPR, 2015, Penyerahan Hasil Panja RUU PPILN - Komisi 9 Mengadakan Rapat Panja RUU PPILN - http://wikidpr.org/rangkuman/penyerahan-hasil-panja-ruu-ppilnkomisi-9-mengadakan-rapat-panja-ruu-ppiln, diakses pada 5 Juni 2017.

52 lbid.
} 
Di akhir tahun 2015, pada rangkaian peringatan hari Buruh Migran Internasional pada 18 Desember 2015, Jaringan Buruh Migran (JBM), yang beranggotakan 28 serikat buruh migran di dalam dan luar negeri, organisasi perempuan dan organisasi yang peduli terhadap isu buruh migran merilis pernyataan berjudul Menagih Komitmen Harmonisasi Konvensi Migran: 3,5 Tahun Pengesahan Konvensi Migran 1990, sebagai berikut:

"Langkah ratifikasi, seharusnya langsung diikuti dengan harmonisasi kebijakan baik di tingkat nasional maupun lokal. Hal ini juga jelas tercantum di dalam visi misi Jokowi-Jusuf Kalla ketika kampanye yang menyatakan bahwa kami (Jokowi-JK) berkomitmen menginisiasi pembuatan peraturan perundang-undangan dan langkah-langkah perlindungan bagi semua pekerja rumah tangga, yang bekerja di dalam dan luar negeri, memberikan perlindungan bagi pekerja/buruh migran melalui ..., harmonisasi konvensi internasional 1990 tentang perlindungan hak-hak buruh migran dan anggota keluarganya ke dalam seluruh kebijakan terkait migrasi tenaga kerja. Namun hingga tiga tahun Konvensi ini diratifikasi, belum terlihat langkah-langkah signifikan dari pemerintah terkait harmonisasi kebijakan maupun langkah implementasi lainnya. Proses revisi UU No. 39 Tahun 2004 belum menghasilkan sebuah perubahan yang signifikan dan mencakup perlindungan komprehensif bagi Buruh Migran". ${ }^{53}$

Pernyataan di atas menunjukkan bahwa tuntutan dari organisasi masyarakat sipil terhadap harmonisasi konvensi internasional perlindungan hak pekerja migran juga dilakukan. Tentu tuntutan ini perlu direspon oleh para pemangku kepentingan (stakeholder) baik dari pihak eksekutif maupun legislatif.

Di awal 2016, Komisi IX DPR RI terpantau melalui WikiDPR masih melakukan rapat mengenai RUU Perubahan UU No. 39 Tahun 2004 yakni

\footnotetext{
${ }^{53}$ Serikat Buruh Migran Indonesia, 2015, Rilis JBM: Menagih Komitmen Harmonisasi Konvensi Migran - http://sbmi.or.id/2015/12/rilis-jbm-menagih-komitmen-harmonisasikonvensi-migran/, diakses 5 Juni 2017.
} 
pada 19 Januari 2016, Komisi IX DPR RI melakukan Rapat Kerja (Raker) dengan Kemenakertrans, Kemendag, KemenPAN-RB, KemenPP-PA, Kemenlu, dan Kemenkumham membahas Rancangan Undang-Undang Perlindungan Pekerja di Luar Negeri (RUU PPILN). ${ }^{54}$ Dari rangkuman yang dihimpun oleh WikiDPR, rapat ini telah mulai memberikan perhatian terhadap harmonisasi konvensi, hal ini terlihat dari pemaparan Menteri Ketenagakerjaan, Hanif Dhakiri mengenai RUU PPILN yang sempat menyeburkan, "pengesahan konfensi dg uu nom 6 th 2012" (pengesahan konvensi dengan UU Nomor 6 Tahun 2012). ${ }^{55}$ Walaupun, pernyataan yang dimaksud oleh Menaker masih belum cukup jelas, tetapi penyebutannya menunjukkan perhatian pemerintah.

Dalam salah satu diskusi yang digelar LSM Migrant Care di Jakarta pada 7 Maret 2016, pemerintah yang diwakili oleh Direktur Perlindungan WNI dan Badan Hukum Indonesia (BHI) Kementerian Luar Negeri RI, Lalu Muhammad lqbal menyatakan bahwa prinsip-prinsip dasar Konvensi PBB Tahun 1990 tentang Perlindungan Hak-Hak Pekerja Migran dan Anggota Keluarganya akan dimasukkan ke dalam RUU Perlindungan Pekerja Indonesia di Luar Negeri (PIPLN). Adopsi ketentuan Konvensi PBB sudah lama diusulkan oleh lembaga advokasi pekerja migran. "Pemerintah juga setuju gagasan itu. Perlu diingat bahwa Konvensi PBB itu telah diratifikasi

\footnotetext{
${ }^{54}$ WikiDPR, 2016, Penyerahan DIM RUU PPILN Kepada DPR: Rapat Kerja Komisi 9 dengan Pemerintah - http://wikidpr.org/rangkuman/penyerahan-dim-ruu-ppiln-kepadadpr---rapat-kerja-komisi-9-dengan-pemerintah, diakses pada 5 Juni 2017. ${ }^{5} \mathrm{lbid}$.
} 
lewat UU No. 6 Tahun 2012. Setelah diratifikasi, konvensi itu mewajibkan negara pihak untuk membentuk UU implementasinya" ${ }^{56}$.

lqbal menyatakan bahwa mengacu amanat konvensi itu sekaligus mengganti UU No. 39 Tahun 2004 pemerintah dan DPR sepakat untuk menindaklanjutinya dalam RUU PPILN. Dengan begitu pemerintah dan DPR tidak perlu membentuk dua UU. Jadi nanti kita hanya membentuk satu undang-undang saja yakni RUU PPILN yang isinya tertuang normanorma utama konvensi PBB 1990 sekaligus merevisi UU PPTKILN. ${ }^{57}$

Dengan mengadopsi konvensi itu lqbal yakin RUU PPILN akan jauh berbeda dengan UU No. 39 Tahun 2004 tentang Penempatan dan Perlindungan Tenaga Kerja Indonesia ke Luar Negeri (PPTKILN). Banyak pihak yang mengkritik UU PPTKILN dan menilai tidak berbasis HAM. la berharap di pasal-pasal awal RUU PPILN menjelaskan secara rinci hakhak buruh migran. Pasal berikutnya menguraikan secara jelas apa saja kewajiban negara. Jika paradigma HAM itu sudah tertuang di awal diharapkan pasal-pasal selanjutnya bisa merefleksikan paradigma tersebut. $^{58}$

Direktur Eksekutif Migrant Care, Anis Hidayah dalam kesempatan yang sama berpendapat sampai saat ini pemerintah belum mengimplementasikan Konvensi PBB Tahun 1990 dalam setiap kebijakan. Diharapkan dalam membahas RUU PPILN pemerintah dan DPR menggunakan konvensi itu sebagai pedoman. Hampir tidak ada kebijakan

\footnotetext{
56 Hukum Online, 2016, RUU PPILN Adopsi Konvensi PBB 1990 http://www.hukumonline.com/berita/baca/lt56dd4946500d5/ruu-ppiln-adopsi-konvensipbb-1990, diakses pada 5 Juni 2017.

${ }^{57}$ lbid.

${ }^{58}$ Ibid.
} 
pemerintah (terkait buruh migran,-red) yang berpegangan pada nilai-nilai HAM. $^{59}$

Analis Kebijakan Migrant Care, Wahyu Susilo, menilai pasca Konvensi PBB Tahun 1990 diratifikasi, tidak ada kebijakan pemerintah yang berdampak signifikan terhadap tata kelola buruh migran. Masih ada perbedaan pandangan antar instansi pemerintah dalam melihat persoalan seputar buruh migran. Misalnya, dalam forum-forum internasional Kementerian Luar Negeri mengedepankan perlindungan WNI termasuk TKI. Sementara Kementerian Ketenagakerjaan merasa konvensi itu sebagai beban. ${ }^{60}$

Berdasarkan penjelasan di atas maka dapat disimpulkan bahwa proses politik dalam adopsi substansi konvensi internasional telah berlangsung sejak masa bakti DPR RI periode 2009-2014 yang juga telah memasukkan RUU Perubahan UU No. 39 Tahun 2004 ke dalam Program Legislasi Nasional (Prolegnas). Setelah Konvensi Internasional Perlindungan Hak Pekerja Migran diratifikasi melalui Rapat Paripurna pada 12 April 2012, namun hingga berakhirnya masa bakti DPR RI periode 2009-2014, RUU Perubahan UU No. 39 Tahun 2004 masih belum tuntas. Dalam proses pembahasan RUU Perubahan tersebut juga dinyatakan oleh salah satu pegiat Jaringan Advokasi Revisi UU PPTKLN menyatakan bahwa pemerintah berkewajiban untuk memasukkan konvensi yang sudah diratifikasi dalam pertimbangan pada RUU perubahan.

\footnotetext{
${ }^{59} \mathrm{lbid}$.

$60 \mathrm{lbid}$.
} 
Memasuki masa bakti DPR RI periode 2014-2019, terpantau melalui WikiDPR, Komisi IX DPR RI melakukan tiga kali rapat yakni pada 23 April 2015, 26 Agustus 2015 dan 19 Januari 2016. Namun baru pada rapat terakhir, pemerintah dalam hal ini Menaker, Hanif Dhakiri menyebutkan mengenai UU No. 6 Tahun 2012 yang merupakan UU pengesahan konvensi internasional perlindungan hak pekerja migran. Di samping itu pada 18 Desember 2015, Jaringan Buruh Migran yang beranggotakan 28 serikat buruh migran di dalam dan luar negeri mengajukan tuntutan menagih komitmen harmonisasi konvensi migran: 3,5 tahun pengesahan konvensi migran 1990 yang dianggap sebagai salah satu dari janji kampanye Joko Widodo dan Jusuf Kalla saat Pemilihan Presiden 2014. Forum diskusi yang digelar LSM Migrant Care di Jakarta pada 7 Maret 2016 yang menghadirkan perwakilan pemerintah dari Kementerian Luar Negeri RI menyatakan bahwa pemerintah setuju dengan gagasan untuk memasukkan Konvensi Internasional Perlindungan Hak Pekerja Migran yang telah diratifikasi lewat UU No. 6 Tahun 2012 ke dalam RUU Perubahan UU No. 39 Tahun 2004 (RUU PPILN). Namun demikian, Direktur Migrant Care, Anis Hidayah berharap dengan pembahasan RUU PPILN pemerintah dan DPR menggunakan konvensi tersebut sebagai pedoman.

Setelah pemaparan singkat mengenai proses politik dalam adopsi substansi Konvensi Internasional Perlindungan Hak Pekerja Migran. Pembahasan dilanjutkan dengan pengkajian dengan proses hukum terhadap Konvensi Internasional tersebut dengan UU No. 39 Tahun 2004. 
Konvensi Internasional Perlindungan Hak Pekerja Migran sebagaimana telah dipaparkan pada bagian sebelumnya telah diratifikasi melalui UU No. 6 Tahun 2012, walaupun secara teknis proses harmonisasi telah dipaparkan, namun inti dari proses tersebut adalah mengadopsi substansi agar dapat memberikan manfaat bagi perlindungan pekerja migran Indonesia (TKI) di luar negeri.

Pranoto Iskandar, pegiat pekerja migran Indonesia dan juga pendiri Institute of Migrant Rights menyatakan pada umumnya, kebanyakan beranggapan bahwa persoalan yang paling rumit adalah terkait dengan harmonisasi aturan di tingkat nasional terhadap standar internasional. Padahal tidak demikian halnya. Hal ini dikarenakan Indonesia bisa dikatakan sebagai terbanyak dalam keterlibatannya sebagai peserta terhadap instrumen HAM internasional. Selain itu, Convention of Migrant Workers (CMW) sebagai standar internasional dalam praktek migrasi tidaklah menuntut adanya perubahan-perubahan yang mendasar atau dramatis akan tumpang tindih dengan peraturan yang ada karena ia hanya berlaku sebagai penegas komitmen Indonesia terhadap perlindungan hak-hak migran. ${ }^{61}$

Pranoto menyatakan bahwa Convention of Migrant Workers (CMW) merupakan rujukan yang paling komprehensif bagi praktek migrasi di tingkat lokal dan internasional. Nilai penting CMW tidak bisa dilepaskan dari 7 fitur yang dikandungnya: (1) langkah awal bagi perlindungan HAM dasar; (2) menawarkan pendekatan HAM dalam isu pekerja migran; (3)

${ }^{61}$ Pranoto Iskandar (ed.), (2011), Standar Internasional Migrasi Ketenagakerjaan Berbasis HAM, Cianjur: IMR Press, h. 64. 
mengangkat situasi buruk yang dihadapi oleh sebagian pekerja migran; (4) bersifat komprehensif mulai dari pembahasan sampai pemulangan; (5) pengakuan secara tegas akan HAM para migran tanpa mempertimbangkan status migrasinya; (6) memuat pengertian-pengertian yang telah diakui secara internasional; dan (7) memiliki komite khusus yang ditujukan untuk menangani isu pekerja migran. ${ }^{62}$

Ketentuan konvensi ini berlaku selama seluruh proses pekerja migran dan anggota keluarganya, yang terdiri dari persiapan untuk migrasi, pemberangkatan, transit dan seluruh masa tinggal dan pekerjaan yang dibayar di dalam negara tempat bekerja dan juga kembalinya ke negara asal atau negara tempatnya bertempat tinggal. Dan negara asal, negara tempat bekerja atau negara transit berkewajiban memberitahukan hak-hak yang muncul dari konvensi ini kepada pekerja migran dan anggota keluarganya, baik kondisi pemeriksaan mereka, hak dan kewajiban pekerja migran menurut hukum dan praktek negara yang bersangkutan. Dalam ketentuan konvensi ini telah diatur tentang jenis, macam dan bentuk-bentuk hak pekerja migran antara lain:

1) Hak anti diskriminasi, hak ini berkaitan dengan hak pekerja migran guna memperoleh hak yang diatur dalam konvensi ini tanpa diskriminasi, baik jenis kelamin, ras, warna kulit, bahasa, agama, kepercayaan, etnis dan lain-lain;

2) Hak hidup;

${ }^{62}$ Ibid, h. 43. 
3) Hak bebas dari kekerasan, penyiksaan dan perlakuan tidak manusiawi lainnya;

4) Kebebasan untuk berpikir, keyakinan dan beragama;

5) Hak berpendapat;

6) Hak untuk bebas bekerja;

7) Hak keamanan pribadi dan privasi serta berkomunikasi dengan orang lain;

8) Perlindungan yang baik dalam proses kerja;

9) Hak atas perawatan kesehatan;

10)Hak atas pendidikan berdasarkan persamaan perlakuan dengan warga negara dari negara yang bersangkutan;

11) Hak untuk berlibur;

12)dan lain sebagainya. ${ }^{63}$

Hak-hak yang tercantum dalam ketentuan Konvensi Internasional tentang Perlindungan atas Hak Pekerja Migran dan Anggota Keluarganya ini terdapat dalam 3 klasifikasi yaitu:

1. Hak pekerja migran sebagai pekerja, yaitu:

a. Hak untuk bekerja;

b. Hak untuk diakui secara hukum sebagai pekerja;

c. Hak atas kondisi kerja yang layak;

d. Hak atas rasa aman dan kondisi kerja yang aman;

e. Hak untuk memiliki dan memelihara kehidupan pribadi;

f. Hak untuk berorganisasi dan berserikat;

${ }^{63}$ Ismantoro Dwi Yuwono, op.cit., hh. 118-119. 
g. Hak untuk bebas dari kerja paksa dan perbudakan.

2. Hak pekerja migran sebagai warga, yaitu bahwa pekerja migran adalah sekaligus warga komunitas asalnya, warga negara dan warga dunia, sehingga mereka berhak diakui potensinya untuk berkontribusi terhadap kehidupan bermasyarakat di negara asing tempatnya bekerja.

3. Hak pekerja migran sebagai perempuan. Hak ini didasarkan pada kondisi perempuan yang rentan terhadap kekerasan termasuk jati dirinya. Konteks Indonesia hak ini juga sangat penting karena mayoritas pekerja migran adalah perempuan, antara lain: hak atas integritas jiwa dan raga, khususnya untuk bebas dari segala bentuk kekerasan fisik, psikis dan seksual, hak untuk bebas dari diskriminasi berbasis gender, hak atas senksualitas dan kesehatan reproduksi, termasuk pengetahuan tentang hal ini dan akses termasuk pengetahuan tentang hal ini dan akses pada layanan kesehatan yang bermutu, hak untuk mendapatkan pemberdayaan dan pendampingan sebagai perempuan. $^{64}$

Dalam konvensi internasional ini diatur secara tegas mengenai aspek dari kewajiban negara, baik negara asal maupun negara tempat pekerja migran bekerja. Kewajiban-kewajiban tersebut adalah sebagai berikut:

${ }^{64}$ Ibid. hh. 119-120. 
1. Kewajiban untuk memberikan perlindungan efektif terhadap kekerasan fisik, kerugian fisik, ancaman dan intimidasi, baik yang dilakukan oleh pejabat publik maupun perorangan, kelompok maupun lembaga termasuk verifikasi oleh petugas penegak hukum harus dilakukan sesuai dengan prosedur hukum yang berlaku;

2. Negara wajib memberitahukan setiap penangkapan terhadap pekerja migran dan anggota keluarganya, termasuk alasannya, serta tuduhan yang diajukan dengan menggunakan bahasa yang dimengerti oleh mereka;

3. Kewajiban memberitahukan setiap penangkapan, penahanan, selama menunggu untuk diadili dan penahanan dalam bentuk lainnya, kepada konsuler atau pejabat diplomatik negara asalnya apabila yang bersangkutan memintanya;

4. Kewajiban memberitahukan hak-hak dan kesempatan kepada pekerja yang ditahan untuk berkomunikasi dengan pejabatpejabat tertentu;

5. Negara harus memberitahukan hak-haknya berdasarkan perjanjian internasional lain yang berlaku antara negara-negara yang bersangkutan untuk berkorespondensi dan bertemu dengan pejabat tersebut di atas, dan mengatur advokat dengan mereka;

6. Kewajiban untuk melaksanakan peradilan guna menentukan keabsahan penahanan dan memerintahkan pembebasan 
apabila penahanan tersebut ternyata tidak sah menurut hukum. Negara wajib memberikan ganti kerugian terhadap penahanan yang dilakukan secara melawan hukum;

7. Kewajiban untuk menyediakan bantuan hukum, penerjemah, jika perlu tanpa membayar;

8. Kewajiban untuk melakukan tindakan yang manusiawi, menghormati martabat yang melekat pada diri manusia dan identitas budaya terhadap pekerja migran dan anggota keluarganya yang ditahan;

9. Kewajiban negara untuk memisahkan dari orang yang dipidana terhadap pekerja migran dan anggota keluarganya yang dikenakan tuduhan. Terdakwa di bawah umur harus dipisahkan dari orang dewasa, dan segera mungkin dihadapkan ke siding pengadilan;

10. Kewajiban negara untuk memisahkan dari orang yang dipidana atau tengah menunggu persidangan terhadap pekerja migran dan anggota keluarganya yang ditahan karena melanggar ketentuan migrasi;

11. Negara harus menjamin bahwa perbuatan seseorang yang menghancurkan atau mencoba menghancurkan dokumen identitas, dokumen yang memberikan ijin masuk atau keluar, tempat kediaman, atau tempat tinggal dalam wilayah nasional, atau ijin kerja merupakan perubahan melawan hukum; 
12. Negara tempat bekerja yang melakukan pengusiran tidak boleh mengurangi hak apapun yang telah diperoleh pekerja migran dan anggota keluarganya sesuai dengan hukum negara tersebut, termasuk hak untuk menerima upah/gaji dan hal lain yang menjadi haknya;

13. Negara harus melindungi hak-hak pekerja migran dan memastikan hak-hak tersebut dijalankan oleh majikan dengan perjanjian kerja. $^{65}$

Konvensi ini juga membagi kategori hak-hak pekerja migran/TKI menjadi dua yakni hak asasi untuk pekerja migran dan keluarganya secara umum dan hak pekerja. Berikut daftar hak pekerja migran dalam Konvensi yang dikutip dari kertas kerja Human Rights Working Group (2010) berjudul "Ratifikasi Konvensi Perlindungan Hak Semua Pekerja Migran dan Anggota Keluarganya! Belajar dari Meksiko”. Hak yang dijamin bagi semua pekerja migran dan keluarganya, di antara hak-hak tersebut adalah:

1. Bebas keluar masuk dari negara asal. Hak ini tidak boleh dibatasi kecuali pada kasus-kasus yang:

a. Ditentukan oleh Undang-Undang;

b. Dipandang perlu untuk melindungi keselamatan bangsa, keteraturan masyarakat, kesehatan masyarakat dan moral atau hak dan kebebasan orang lain;

65 lbid. hh. 121-123. 
c. Konsisten dengan hak-hak lain yang diakui dalam bagian Konvensi yang masih berlaku (Pasal 8).

2. Hak atas kehidupan yang dilindungi oleh hukum (Pasal 9);

3. Hak untuk tidak menjadi korban penyiksaan atau bentuk-bentuk tindakan atau hukuman yang kejam, tidak manusiawi dan merendahkan (Pasal 10);

4. Bebas dari perbudakan atau memberikan pelayanan kerja paksa, termasuk kerja dalam tahanan (Pasal 11);

5. Hak untuk bebas berpikir, memiliki keyakinan dan berpendapat (Pasal 12);

6. Hak untuk memiliki pendapat yang bebas dari intervensi bebas berekspresi termasuk bebas untuk mencari, menerima dan berbagai informasi (Pasal 13);

7. Bebas dari bentuk intervensi sewenang-wenang maupun di luar hukum terhadap privasi yang bersangkutan (Pasal 14);

8. Hak untuk memiliki properti/barang-barang dan bebas dari perampasan harta yang sewenang-wenang (Pasal 15);

9. Hak kebebasan atau keselamatan individu (Pasal 16);

10. Hak atas proses hukum yang sesuai dengan Undang-Undang dalam kasus-kasus terjadinya tindakan kejahatan (Pasal 17 dan 18);

11. Tidak ada penyitaan atau penghancuran terhadap dokumen identitas, atau dokumen izin masuk atau izin tinggal atau izin kerja (Pasal 19); 
12. Tidak ada pemecatan/dipulangkan secara kolektif. Setiap kasus pemecatan akan dikaji dan diputuskan secara individual, kecual diputuskan oleh pejabat yang kompeten, sesuai dengan Undang-Undang (Pasal 21) dan pembiayaan pemulangan (Pasal 22);

13. Hak untuk meminta perlindungan dan bantuan dari konsuler atau perwakilan diplomatik Negara yang bersangkutan (Pasal 23);

14. Hak untuk memperoleh pengakuan sebagai individu di depan hukum (Pasal 24);

15. Hak untuk memperoleh perlakuan yang adil sesuai kewarganegaraan terkait dengan penghasilan (Pasal 25);

16. Bebas berasosasi atau memiliki hak untuk bergabung dengan serikat pekerja (Pasal 26);

17. Hak untuk memperoleh jaminan sosial; sesuai dengan kewarganegaraannya jika memenuhi persyaratan (Pasal 27);

18. Hak untuk memperoleh pelayanan kesehatan (Pasal 28);

19. Penghormatan atas identitas budaya pekerja migran dan anggota keluarga mereka (Pasal 29);

20. Hak untuk memindahkan pendapatan atau simpanan mereka, barang-barang milik pribadi, saat berakhirnya izin tinggal, sesuai dengan Undang-Undang yang berada dalam Negara terkait (Pasal 30-32); 
21. Hak untuk diberitahukan mengenai hak-hak mereka berdasarkan Perjanjian, persyaratan izin masuk, serta hak-hak dan kewajiban mereka berdasarkan Undang-Undang dari Negara penerima (Pasal 33).

Hasil kajian naskah akademik RUU Perubahan UU No. 39 Tahun 2004 (RUU PPILN versi 7 Juni 2012) mengacu pada standar internasional yang ada dalam Konvensi ILO dan Konvensi Perlindungan Hak Pekerja Migran dan Anggota Keluarganya, dalam seluruh proses migrasi pekerja migran terdapat hak-hak pekerja migran yang semestinya dipenuhi. Berikut adalah hak-hak pekerja migran selama proses migrasi:

Tabel 4.9 Hak Pekerja Migran Selama Proses Migrasi

\begin{tabular}{|c|c|c|}
\hline No. & Proses Migrasi & Hak Pekerja Migran \\
\hline \multirow[t]{3}{*}{1.} & $\begin{array}{l}\text { Pra } \\
\text { pemberangkatan } \\
\text { dan perjalanan } \\
\text { ke negara tujuan }\end{array}$ & \\
\hline & $\begin{array}{l}\text { 1.1. Pemberian } \\
\text { informasi }\end{array}$ & $\begin{array}{l}\text { Mendapatkan informasi tentang kondisi kerja } \\
\text { dan kehidupan di negara tujuan. } \\
\text { Informasi disediakan dengan cara yang bisa } \\
\text { diakses calon pekerja migran dan diberikan } \\
\text { dalam bahasa yang bisa dipahami para } \\
\text { pekerja migran. } \\
\text { Informasi diberikan secara cuma-cuma } \\
\text { Ada tindakan tegas terhadap mereka yang } \\
\text { memberikan informasi tidak benar terkait } \\
\text { dengan migrasi pekerja migrant }\end{array}$ \\
\hline & 1.2. Perekrutan & $\begin{array}{l}\text { Perekrutan pekerja migran dilakukan oleh: } \\
\text { badan pemerintah, majikan yang prospektif, } \\
\text { dan agen tenaga kerja yang } \\
\text { resmi/terakreditasi } \\
\text { Majikan dan agensi perekrut tenaga kerja } \\
\text { harus mendapat ijin dari lembaga } \\
\text { pemerintah } \\
\text { Monitoring dan pengawasan ketat terhadap } \\
\text { majikan dan agen perekrut untuk mencegah } \\
\text { terjadinya hal-hal berikut: } \\
\text { 1. tingginya biaya perekrutan yang }\end{array}$ \\
\hline
\end{tabular}




\begin{tabular}{|c|c|}
\hline & $\begin{array}{l}\text { dibebankan kepada pekerja migran } \\
\text { 2. kecurangan dalam pembuatan dan } \\
\text { pelaksanaan kontrak } \\
\text { 3. pemberian informasi yang tidak benar } \\
\text { 4. pelanggaran atas ketentuan imigrasi atau } \\
\text { penempatan pekerja migran tanpa } \\
\text { dokumen } \\
\text { * Pemberian ijin pada agen diberikan hanya } \\
\text { untuk sektor kerja tertentu } \\
\text { Pekerja migran tidak dikenakan biaya } \\
\text { perekrutan. Kalaupun ada biaya yang } \\
\text { dibebankan pada pekerja migran, jumlahnya } \\
\text { harus sangat terbatas } \\
\text { Majikan dan agen dilarang melakukan } \\
\text { pemotongan gaji pekerja migran. }\end{array}$ \\
\hline $\begin{array}{l}\text { 1.3. Penandata- } \\
\text { nganan kontrak }\end{array}$ & $\begin{array}{l}\text { Sebelum berangkat ke negara tujuan, } \\
\text { pekerja migran berhak untuk mendapatkan } \\
\text { perjanjian kerja tertulis yang berisi tentang } \\
\text { pekerjaan, ruang lingkup pekerjaan, kondisi } \\
\text { kerja, besarnya upah/gaji dan jangka waktu } \\
\text { berlangsungnya kontrak. } \\
\text { *erjanjian kerja dan dokumen lainnya ditulis } \\
\text { dalam bahasa yang dimengerti pekerja } \\
\text { migran. Bila yang bersangkutan } \\
\text { berpendidikan rendah, maka isi kontrak } \\
\text { harus dijelaskan pada yang bersangkutan } \\
\text { Perjanjian kerja dan ijin kerja tidak boleh } \\
\text { melanggar hak pekerja migran yang dijamin } \\
\text { dalam konvensi. Misalnya, tidak boleh ada } \\
\text { ketentuan yang melarang pekerja migran } \\
\text { untuk masuk dalam serikat pekerja, untuk } \\
\text { tidak menikah, untuk hamil atau mewajibkan } \\
\text { pekerja migran untuk tes kehamilan secara } \\
\text { berkala }\end{array}$ \\
\hline $\begin{array}{l}\text { 1.4. Tes dan } \\
\text { pelayanan } \\
\text { kesehatan }\end{array}$ & $\begin{array}{l}\text { Pekerja migran berhak atas tes dan } \\
\text { pelayanan kesehatan sebelum berangkat, } \\
\text { selama dalam perjalanan dan ketika sampai } \\
\text { di negara tujuan } \\
\text { *ekerja migran tidak dipaksa/diwajibkan } \\
\text { untuk menjalani tes kesehatan yang tidak } \\
\text { terjaga kerahasiaannya, seperti test } \\
\text { kehamilan, tes HIV/AID, dll. } \\
\text { *ekerja migran tidak dihilangkan haknya } \\
\text { untuk bekerja ketika positif hamil atau } \\
\text { mengidap HIV/AID }\end{array}$ \\
\hline $\begin{array}{l}1.5 . \\
\text { Pemberangkatan }\end{array}$ & $\begin{array}{l}\text { Pekerja migran - khususnya yang baru } \\
\text { pertama kali ke luar negeri - berhak untuk } \\
\text { mendapatkan pelayanan/bantuan dalam }\end{array}$ \\
\hline
\end{tabular}




\begin{tabular}{|c|c|c|}
\hline & & $\begin{array}{l}\text { menghadapi proses terkait dengan proses } \\
\text { perjalanan dan imigrasi. } \\
\text { * Pelayanan diberikan secara cuma-cuma } \\
\text { * Pekerja migran tidak membiayai sendiri } \\
\text { pengeluaran yang dibutuhkan untuk } \\
\text { perjalanan ke negara tujuan. Perekrut dan } \\
\text { majikan wajib menanggung pengeluaran ini } \\
\text { * Bila pekerja migran tidak memiliki kontrak } \\
\text { dengan majikan atau berangkat dengan } \\
\text { inisiatif sendiri, biaya perjalanan dibuat } \\
\text { seminimum mungkin }\end{array}$ \\
\hline 2. & $\begin{array}{l}\text { Tiba di negara } \\
\text { tujuan }\end{array}$ & $\begin{array}{l}\text { * Hak untuk mendapatkan program orientasi } \\
\text { yang diperlukan untuk menyesuaikan } \\
\text { dengan kondisi di negara tujuan } \\
\text { * Hak untuk terbebas dari kewajiban adat } \\
\text { setempat } \\
\text { * Hak untuk mendapatkan pelayanan secara } \\
\text { cuma-cuma dalam menemukan pekerjaan } \\
\text { yang sesuai } \\
\text { * Hak untuk mendapatkan informasi dan } \\
\text { pelayanan yang dibutuhkan untuk } \\
\text { menyesuaikan dengan lingkungan baru } \\
\text { * Hak untuk bebas dari diskriminasi dalam } \\
\text { mendapatkan akomodasi }\end{array}$ \\
\hline 3. & Selama bekerja & $\begin{array}{l}\text { Hak untuk mendapatkan perlakuan yang } \\
\text { sama dengan pekerja lokal terkait dengan } \\
\text { kondisi kerja, termasuk gaji, keanggotaan } \\
\text { dalam serikat buruh, akomodasi, jaminan } \\
\text { sosial (dalam batas tertentu), pajak dan } \\
\text { perlakuan di tempat kerja } \\
\text { * Upah: 1) upah yang sama untuk pekerjaan } \\
\text { yang sama. Besaran upah ditentukan secara } \\
\text { obyektif berdasarkan karakter pekerjaan } \\
\text { (terkait dengan dengan keterampilan, } \\
\text { pengetahuan, kondisi kerja dan tanggung } \\
\text { jawab) dan tidak didasarkan pada jenis } \\
\text { kelamin dan kebangsaan, 2) upah tidak di } \\
\text { bawah standar, 3) upah dibayar langsung, 4) } \\
\text { upah dikelola oleh pekerja } \\
\text { * Perlakuan yang sama dengan pekerja dalam } \\
\text { hal kondisi kerja, seperti: jam kerja, waktu } \\
\text { istirahat, waktu lembur, hari libur, } \\
\text { kesempatan belajar/ training, perlindungan } \\
\text { dari bahan berbahaya, alat berbahaya, } \\
\text { polusi getaran dan suara, perlindungan dari } \\
\text { kekerasan fisik dan seksual, jaminan sosial, } \\
\text { dan pelayanan lainnya } \\
\text { * Hak atas kesehatan dan keselamatan kerja }\end{array}$ \\
\hline
\end{tabular}




\begin{tabular}{|c|c|c|}
\hline & & $\begin{array}{l}\text { Hak atas peluang kerja dan untuk bertukar } \\
\text { pekerjaan } \\
\text { Hak untuk bebas bergerap } \\
\text { Hak untuk mengakses keadilan }\end{array}$ \\
\hline 4. & $\begin{array}{l}\text { Pemulangan dan } \\
\text { reintegrasi }\end{array}$ & $\begin{array}{l}\text { Hak untuk tidak dideportasi dan di-PHK } \\
\text { tanpa alasan sah } \\
\text { Hak untuk mendapatkan bantuan hukum bila } \\
\text { di-PHK sewenang-wenang } \\
\text { Pekerja migran yang gagal bukan atas } \\
\text { kesalahannya mereka tidak harus membayar } \\
\text { sendiri biaya pemulangan ke negara asal } \\
\text { Hak untuk mendapatkan pembayaran upah, } \\
\text { pengembalian upah yang dipotong, } \\
\text { kompensasi hari libur yang tidak diambil, } \\
\text { pembayaran kembali atas kontribusi untuk } \\
\text { jaminan sosial } \\
\text { Akses atas keadilan dan bantuan hukum bila } \\
\text { ada hak yang dilanggar } \\
\text { Hak untuk mendapatkan keamanan dan } \\
\text { bebas dari pemerasan } \\
\text { Hak untuk mendapatkan perlindungan terkait } \\
\text { dengan hasil kerja dan kehidupan sosial }\end{array}$ \\
\hline
\end{tabular}

Sumber: Naskah Akademik RUU PPILN versi 7 Juni 2012

Selain itu, proses adopsi substansi konvensi ke dalam RUU Perubahan UU No. 39 Tahun 2004 perlu memperhatikan tuntutan dari organisasi masyarakat sipil/lembaga swadaya masyarakat, salah satunya tuntutan dari Perhimpunan Indonesia untuk Buruh Migran Berdaulat (LSM Migrant Care) sebagai berikut:

Tabel 4.10 Tuntutan Revisi Berbasis Prinsip-Prinsip Konvensi ILO dan Konvensi Buruh Migran

\begin{tabular}{|l|l|l|l|l|}
\hline No. & $\begin{array}{c}\text { Poin-poin } \\
\text { Perubahan }\end{array}$ & $\begin{array}{c}\text { UU No. } \\
\mathbf{3 9 / 2 0 0 4}\end{array}$ & RUU PPILN & $\begin{array}{l}\text { Usulan } \\
\text { Perubahan } \\
\text { Standar } \\
\text { Internasional }\end{array}$ \\
\hline 1. & $\begin{array}{l}\text { Paradigma } \\
\text { Perlindungan }\end{array}$ & $\begin{array}{l}\text { Bisnis } \\
\text { penempatan }\end{array}$ & $\begin{array}{l}\text { Bisnis } \\
\text { penempatan. } \\
\text { Hanya } \\
\text { mengubah } \\
\text { nama: PPTKIS \& } \\
\text { PPILN }\end{array}$ & $\begin{array}{l}\text { Penegakan HAM } \\
\text { buruh migran } \\
\text { sesuai konstitusi } \\
\text { dan standar } \\
\text { konvensi buruh } \\
\text { migran }\end{array}$ \\
\hline 2. & Keadilan gender & $\begin{array}{l}\text { Tidak } \\
\text { mencerminkan }\end{array}$ & $\begin{array}{l}\text { Belum } \\
\text { mencerminkan }\end{array}$ & $\begin{array}{l}\text { PRT migran } \\
\text { harus diatur }\end{array}$ \\
\hline
\end{tabular}




\begin{tabular}{|c|c|c|c|c|}
\hline & & $\begin{array}{l}\text { prinsip keadilan } \\
\text { gender, hanya } \\
\text { ada satu pasal } \\
\text { tentang } \\
\text { perempuan } \\
\text { "perempuan } \\
\text { hamil dilarang } \\
\text { bekerja di luar } \\
\text { negeri" }\end{array}$ & $\begin{array}{l}\text { prinsip keadilan } \\
\text { gender. PRT } \\
\text { migran sebagai } \\
\text { sektor yang } \\
\text { paling besar } \\
\text { (penempatan } \\
\text { dan masalah) } \\
\text { belum dijawab }\end{array}$ & $\begin{array}{l}\text { dalam bab } \\
\text { khusus karena } \\
\text { memiliki } \\
\text { kerentanan yang } \\
\text { berbeda. Bab } \\
\text { tentang ini dapat } \\
\text { mengadopsi } \\
\text { Konvensi ILO } \\
189 \text { dan GR } 26 \\
\text { komite CEDAW }\end{array}$ \\
\hline 3. & $\begin{array}{l}\text { Ruang lingkup } \\
\text { buruh migran }\end{array}$ & $\begin{array}{l}\text { TKI yang } \\
\text { bekerja di luar } \\
\text { negeri, tidak } \\
\text { termasuk ABK, } \\
\text { anggota } \\
\text { keluarga dan } \\
\text { undocumented } \\
\text { migrant workers }\end{array}$ & $\begin{array}{l}\text { PILN (Pekerja } \\
\text { Ind di luar } \\
\text { negeri) termasuk } \\
\text { ABK, anggota } \\
\text { keluarga, tetapi } \\
\text { belum } \\
\text { memasukkan } \\
\text { undocumented } \\
\text { migrant workers }\end{array}$ & $\begin{array}{l}\text { Buruh migran } \\
\text { dan anggota } \\
\text { keluarga, } \\
\text { termasuk } \\
\text { undocumented } \\
\text { migrant workers, } \\
\text { buruh migran } \\
\text { mandiri dan ABK } \\
\text { yang akan, } \\
\text { tengah dan telah } \\
\text { bekerja di luar } \\
\text { negeri }\end{array}$ \\
\hline 4. & $\begin{array}{l}\text { Jaminan hak-hak } \\
\text { buruh migran }\end{array}$ & $\begin{array}{l}\text { Tidak mengatur } \\
\text { dan menjamin } \\
\text { hak-hak buruh } \\
\text { migran secara } \\
\text { komprehensif }\end{array}$ & $\begin{array}{l}\text { Belum secara } \\
\text { komprehensif } \\
\text { mengatur dan } \\
\text { menjamin hak- } \\
\text { hak buruh } \\
\text { migran sesuai } \\
\text { konvensi, namun } \\
\text { sudah } \\
\text { memasukkan } \\
\text { anggota } \\
\text { keluarga buruh } \\
\text { migrant }\end{array}$ & \\
\hline 5. & $\begin{array}{l}\text { Peranan } \\
\text { PPTKIS/PJTKI }\end{array}$ & $\begin{array}{l}\text { Rekrutmen } \\
\text { training, } \\
\text { penampungan, } \\
\text { perlindungan di } \\
\text { luar negeri, } \\
\text { pemulangan } \\
\text { adalah } \\
\text { tanggungjawab } \\
\text { PPTKIS }\end{array}$ & $\begin{array}{l}\text { Rekrutmen, } \\
\text { training, } \\
\text { pendampingan, } \\
\text { perlindungan di } \\
\text { luar negeri, } \\
\text { pemulangan } \\
\text { adalah } \\
\text { tanggungjawab } \\
\text { PPPILN }\end{array}$ & $\begin{array}{l}\text { Seluruh peranan } \\
\text { PPTKIS } \\
\text { diberikan kepada } \\
\text { Pemda sebagai } \\
\text { pelayanan } \\
\text { publik. Peran } \\
\text { PPTKIS hanya } \\
\text { terbatas travel } \\
\text { (tiket perjalanan } \\
\text { TKI) }\end{array}$ \\
\hline 6. & $\begin{array}{l}\text { Training Pra } \\
\text { Pemberangkatan }\end{array}$ & $\begin{array}{l}\text { Diselenggarakan } \\
\text { oleh PPTKIS } \\
\text { dan PAP oleh } \\
\text { pemerintah. } \\
\text { Materi training } \\
\text { tidak } \\
\text { komprehensif }\end{array}$ & $\begin{array}{l}\text { Diselenggarakan } \\
\text { oleh PPPILN } \\
\text { dan PAP dengan } \\
\text { kurikulum yang } \\
\text { sama }\end{array}$ & $\begin{array}{l}\text { Diselenggarakan } \\
\text { oleh Pemda di } \\
\text { BLK daerah, } \\
\text { kurikulum } \\
\text { disusun oleh } \\
\text { Komisi } \\
\text { Perlindungan } \\
\text { dengan }\end{array}$ \\
\hline
\end{tabular}




\begin{tabular}{|c|c|c|c|c|}
\hline & & & & $\begin{array}{l}\text { menekankan } \\
\text { pada materi } \\
\text { HAM dan hukum } \\
\text { neaara setempat }\end{array}$ \\
\hline 7. & $\begin{array}{l}\text { Biaya } \\
\text { penempatan }\end{array}$ & $\begin{array}{l}\text { Beban TKI: } \\
\text { pengurusan } \\
\text { dokumen, } \\
\text { asuransi, biaya } \\
\text { perlindungan } \\
\text { dan training } \\
\text { Majikan: tiket, } \\
\text { visa, asuransi } \\
\text { dan biaya agen }\end{array}$ & $\begin{array}{l}\text { Beban TKI: } \\
\text { pengurusan } \\
\text { dokumen dan } \\
\text { training } \\
\text { Majikan: tiket, } \\
\text { visa, asuransi } \\
\text { dan biaya agen }\end{array}$ & $\begin{array}{l}\text { Pelayanan publik } \\
\text { akan } \\
\text { menciptakan } \\
\text { migrasi tidak } \\
\text { berbiaya tinggi. } \\
\text { Pemerintah } \\
\text { harus } \\
\text { mengalokasikan } \\
\text { anggaran untuk } \\
\text { training. Buruh } \\
\text { migrant hanya } \\
\text { dibebani untuk } \\
\text { pengurusan } \\
\text { dokumen }\end{array}$ \\
\hline 8. & Pengawasan & $\begin{array}{l}\text { Pengawasan } \\
\text { dilakukan oleh } \\
\text { pemerintah, } \\
\text { pengawas } \\
\text { ketenagakerjaan }\end{array}$ & $\begin{array}{l}\text { Pengawasan } \\
\text { dilakukan oleh } \\
\text { pemerintah, } \\
\text { pengawas } \\
\text { ketenagakerjaan }\end{array}$ & $\begin{array}{l}\text { Harus ada } \\
\text { pengawas } \\
\text { ketenagakerjaan } \\
\text { untuk buruh } \\
\text { migran. } \\
\text { Ombudsman } \\
\text { juga harus } \\
\text { masuk dalam } \\
\text { mekanisme } \\
\text { pengawasan }\end{array}$ \\
\hline 9. & $\begin{array}{l}\text { Perlindungan } \\
\text { dan bantuan } \\
\text { hukum }\end{array}$ & $\begin{array}{l}\text { Perlindungan } \\
\text { dan bantuan } \\
\text { hukum lebih } \\
\text { banyak } \\
\text { dibebankan } \\
\text { kepada PPTKIS } \\
\text { dan asuransi } \\
\text { TKI, namun } \\
\text { tidak efektif }\end{array}$ & $\begin{array}{l}\text { Perlindungan } \\
\text { dan bantuan } \\
\text { hukum diberikan } \\
\text { oleh pemerintah } \\
\text { di dalam dan } \\
\text { luar negeri }\end{array}$ & $\begin{array}{l}\text { Perlindungan } \\
\text { dan bantuan } \\
\text { hukum diberikan } \\
\text { secara integratif } \\
\text { di dalam dan } \\
\text { luar negeri oleh } \\
\text { pemerintah. } \\
\text { Untuk bantuan } \\
\text { hukum merujuk } \\
\text { pada UU tentang } \\
\text { bantuan hukum } \\
\text { tahun } 2011\end{array}$ \\
\hline 10. & Asuransi & $\begin{array}{l}\text { Asuransi } \\
\text { diselenggarakan } \\
\text { oleh pemerintah }\end{array}$ & $\begin{array}{l}\text { Asuransi TKI } \\
\text { diselenggarakan } \\
\text { oleh pemerintah } \\
\text { secara gratis }\end{array}$ & $\begin{array}{l}\text { Asuransi } \\
\text { integratif dalam } \\
\text { SJSN. Model } \\
\text { asuransi bagi } \\
\text { buruh migran } \\
\text { adalah trust } \\
\text { fund, seperti } \\
\text { tabungan. } \\
\text { Bermasalah atau } \\
\text { tidak asuransi } \\
\text { bisa di klaim. }\end{array}$ \\
\hline
\end{tabular}




\begin{tabular}{|c|c|c|c|c|}
\hline 11. & Kartu Identitas & $\begin{array}{l}\text { Setiap TKI harus } \\
\text { diasuransikan } \\
\text { KTKLN wajib }\end{array}$ & $\begin{array}{l}\text { KTKLN tetap } \\
\text { wajib, namun } \\
\text { istilahnya diganti } \\
\text { dengan KPILN } \\
\text { wajib }\end{array}$ & $\begin{array}{l}\text { KTKLN } \\
\text { dihapuskan } \\
\text { karena menjadi } \\
\text { beban baru bagi } \\
\text { pemerasan } \\
\text { buruh migran }\end{array}$ \\
\hline 12. & $\begin{array}{l}\text { Kepulangan TKI } \\
\text { dan Purna TKI }\end{array}$ & $\begin{array}{l}\text { Kepulangan TKI } \\
\text { di bawah } \\
\text { tanggungjawab } \\
\text { majikan dan } \\
\text { agen. Dan } \\
\text { pemerintah bagi } \\
\text { yang tidak } \\
\text { memiliki agen. } \\
\text { Tidak ada } \\
\text { program bagi } \\
\text { purna TKI }\end{array}$ & $\begin{array}{l}\text { Kepulangan TKI } \\
\text { di bawah } \\
\text { tanggung jawab } \\
\text { majikan dan } \\
\text { agen. Dan } \\
\text { pemerintah bagi } \\
\text { yang tidak } \\
\text { memiliki agen. } \\
\text { Tidak ada } \\
\text { program bagi } \\
\text { purna TKI }\end{array}$ & $\begin{array}{l}\text { Kepulangan } \\
\text { buruh migran } \\
\text { menjadi } \\
\text { tanggung jawab } \\
\text { pemerintah dan } \\
\text { beban biaya juga } \\
\text { pada majikan. } \\
\text { Kepulangan } \\
\text { buruh migran } \\
\text { tidak boleh } \\
\text { sentralisir di } \\
\text { Jakarta, terminal } \\
\text { TKI harus } \\
\text { dihapuskan. } \\
\text { Untuk TKI purna } \\
\text { harus ada } \\
\text { program } \\
\text { pemberdayaan }\end{array}$ \\
\hline 13. & $\begin{array}{l}\text { Mekanisme } \\
\text { penyelesaian } \\
\text { masalah }\end{array}$ & $\begin{array}{l}\text { PJTKI } \\
\text { bertanggung } \\
\text { jawab untuk } \\
\text { menyelesaikan } \\
\text { masalah TKI }\end{array}$ & $\begin{array}{l}\text { PJTKI secara } \\
\text { bersama-sama } \\
\text { dengan } \\
\text { pemerintah } \\
\text { menyelesaikan } \\
\text { masalah TKI }\end{array}$ & $\begin{array}{l}\text { Pemerintah } \\
\text { bertanggung } \\
\text { jawab } \\
\text { menyelesaikan } \\
\text { masalah buruh } \\
\text { migrant. Untuk } \\
\text { persoalan } \\
\text { hukum } \\
\text { diperlukan } \\
\text { pengadilan ad } \\
\text { hoc buruh } \\
\text { migrant }\end{array}$ \\
\hline 14. & $\begin{array}{l}\text { Peran } \\
\text { masyarakat sipil }\end{array}$ & Tidak diatur & Tidak diatur & $\begin{array}{l}\text { Dalam konsep } \\
\text { demokrasi dan } \\
\text { tata } \\
\text { pemerintahan } \\
\text { yang baik, } \\
\text { masyarakat sipil } \\
\text { merupakan } \\
\text { salah satu pihak } \\
\text { yang dapat } \\
\text { berpartisipasi. } \\
\text { Dan dalam } \\
\text { upaya } \\
\text { perlindungan } \\
\text { dan } \\
\text { pemberdayaan } \\
\text { buruh migran di }\end{array}$ \\
\hline
\end{tabular}




\begin{tabular}{|c|c|c|c|c|}
\hline & & & & $\begin{array}{l}\text { dalam dan di } \\
\text { luar negeri, } \\
\text { masyarakat sipil } \\
\text { selama secara } \\
\text { nyata melakukan } \\
\text { advokasi dan } \\
\text { pendampingan } \\
\text { bagi buruh } \\
\text { migran. } \\
\text { Sehingga dalam } \\
\text { UU harus diatur } \\
\text { perannya }\end{array}$ \\
\hline 15. & $\begin{array}{l}\text { Penegakan } \\
\text { hukum }\end{array}$ & $\begin{array}{l}\text { Lebih banyak } \\
\text { sanksi } \\
\text { administratif }\end{array}$ & $\begin{array}{l}\text { Sanksi pidana } \\
\text { bagi pelanggar } \\
\text { penempatan TKI } \\
\text { termasuk aparat } \\
\text { pemerintah }\end{array}$ & $\begin{array}{l}\text { Sanksi pidana } \\
\text { harus memiliki } \\
\text { efek jera. } \\
\text { Merujuk pada } \\
\text { UU Nomor } 21 \\
\text { tahun } 2007 \\
\text { tentang } \\
\text { trafficking }\end{array}$ \\
\hline 16. & Kelembagaan & $\begin{array}{l}\text { Membentuk } \\
\text { BNP2TKI. } \\
\text { Menimbulkan } \\
\text { konflik } \\
\text { kelembagaan } \\
\text { antara BNP2TKI } \\
\text { dengan } \\
\text { Kemenakertrans } \\
\text { (Pasal 11, 95, } \\
98 \text { ) }\end{array}$ & $\begin{array}{l}\text { Hanya } \\
\text { mengubah istilah } \\
\text { BNP2TKI } \\
\text { menjadi } \\
\text { BPPPILN }\end{array}$ & $\begin{array}{l}\text { Mengusulkan } \\
\text { dibentuknya } \\
\text { Komisis } \\
\text { Perlindungan } \\
\text { Buruh Migran } \\
\text { Indonesia. Serta } \\
\text { badan-badan } \\
\text { khusus, seperti } \\
\text { urusan } \\
\text { kesejahteraan, } \\
\text { pemenuhan hak } \\
\text { politik. Dan } \\
\text { penguatan atase } \\
\text { tenaga kerja. } \\
\text { BNP2TKI } \\
\text { dihapuskan. }\end{array}$ \\
\hline
\end{tabular}

Sumber: Lembar Wujudkan Payung Hukum bagi Perlindungan dan Pemenuhan Hak-Hak Buruh Migran Indonesia dan Anggota Keluarganya dari Perhimpunan Indonesia untuk Buruh Migran Berdaulat (Migrant Care)

Tabel di atas menitikberatkan pada 16 poin perubahan yang diajukan antara lain: (1) paradigma perlindungan; (2) keadilan gender; (3) ruang lingkup buruh migran; (4) jaminan hak-hak buruh migran; (5) peranan PPTKIS/PJTKI; (6) training pra-pemberangkatan; (7) biaya penempatan; (8) pengawasan; (9) perlindungan dan bantuan hukum; (10) asuransi; (11) kartu identitas; (12) kepulangan TKI dan purna TKI; (13) 
mekanisme penyelesaian masalah; (14) peran masyarakat sipil; (15) penegakan hukum dan (16) kelembagaan.

Proses adaptasi substansi konvensi juga perlu mengkaji pokokpokok pikiran RUU Perubahan UU Nomor 39 Tahun 2004 dari perspektif pemerintah, sebagai berikut:

Tabel 4.11 Pokok-Pokok Pikiran RUU Perubahan UU Nomor 39 Tahun 2004

\begin{tabular}{|c|c|c|}
\hline No. & Permasalahan & Usulan Materi Perubahan UU \\
\hline $\mathrm{I}$ & Umum & \\
\hline 1. & $\begin{array}{l}\text { - UU No. } 39 / 2004 \text { belum } \\
\text { dapat menyelesaikan } \\
\text { seluruh permasalahan } \\
\text { TKI yang terjadi selama } \\
\text { ini } \\
\text { - Banyaknya kelemahan } \\
\text { dalam UU No. 39/2004 } \\
\text { antara lain ketentuan } \\
\text { tentang proses } \\
\text { penempatan hanya dapat } \\
\text { diterapkan terhadap } \\
\text { PLRT, tidak dapat } \\
\text { diterapkan ke semua jenis } \\
\text { pekerjaan TKLN lainnya, } \\
\text { misalnya pelaut }\end{array}$ & $\begin{array}{l}\text { UU yang diharapkan adalah UU yang } \\
\text { dapat menjawab segala permasalahan } \\
\text { TKI selama ini dan dapat memperbaiki } \\
\text { kelemahan/kekurangan yang ada dalam } \\
\text { UU No. 39/2004 }\end{array}$ \\
\hline 2. & $\begin{array}{l}\text { UU No. 39/2004 tidak } \\
\text { menjelaskan secara } \\
\text { eksplisit peran dan } \\
\text { kewenangan } \\
\text { Kementerian/Lembaga }\end{array}$ & $\begin{array}{l}\text { UU yang diharapkan kedepan adalah } \\
\text { UU yang implementatif, komprehensif, } \\
\text { tidak multi tafsir, tidak tumpang tindih } \\
\text { kewenangan dan lebih memberikan } \\
\text { perlindungan kepada TKI }\end{array}$ \\
\hline 3. & $\begin{array}{l}\text { UU No. 39/2004 terlalu } \\
\text { banyak memuat blank } \\
\text { mandat dalam bentuk } \\
\text { Peraturan Menteri } \\
\text { sehingga sulit untuk } \\
\text { ditaati oleh instansi K/L }\end{array}$ & $\begin{array}{l}\text { - Peraturan pelaksanaan lebih baik } \\
\text { diatur dalam bentuk Peraturan } \\
\text { Pemerintah atau Peraturan Presiden } \\
\text { - Pengaturan yang sangat teknis diatur } \\
\text { dalam Permenaker atau Peraturan } \\
\text { Kepala BNP2TKI }\end{array}$ \\
\hline 4. & $\begin{array}{l}\text { Isu TKI banyak } \\
\text { menyangkut isu HAM }\end{array}$ & $\begin{array}{l}\text { - RUU harus lebih berperspektif HAM } \\
\text { dan mengakomodir ketentuan-ketentuan } \\
\text { Konvensi PBB dan konvensi ILO yang } \\
\text { meyangkut HAM } \\
\text { - Indonesia telah meratifikasi seluruh (8) }\end{array}$ \\
\hline
\end{tabular}




\begin{tabular}{|l|l|l|}
\hline & & konvensi ILO dan beberapa Konvensi \\
PBB tentang HAM
\end{tabular}




\begin{tabular}{|c|c|c|}
\hline 8. & & $\begin{array}{l}\text { Rekomendasi: } \\
\text { RUU juga mengakomodir rekomendasi } \\
\text { dari berbagai pihak (KPK, BPK, Komnas } \\
\text { HAM, Komisi Perlindungan Anak, } \\
\text { Ombudsman, LSM dan Serikat Buruh) } \\
\text { yang bertujuan untuk perbaikan Tata } \\
\text { Kelola TKI }\end{array}$ \\
\hline II & Isi/Substansi RUU & \\
\hline 1. & $\begin{array}{l}\text { Istilah TKI dikonotasikan } \\
\text { sebagai PLRT dan } \\
\text { persepsi masyarakat } \\
\text { yang negatif terhadap } \\
\text { istilah TKI }\end{array}$ & $\begin{array}{l}\text { Alternatif 1: } \\
\text { Istilah TKI diganti menjadi Tenaga Kerja } \\
\text { Luar Negeri (TKLN) sehingga judul RUU } \\
\text { menjadi UU tentang TKLN dan } \\
\text { BNP2TKI menjadi BNTKLN } \\
\text { Alternatif 2: } \\
\text { Istilah TKI diganti menjadi Pekerja } \\
\text { Migran dan BNP2TKI menjadi Badan } \\
\text { Koordinasi Pekerja Migran }\end{array}$ \\
\hline 2. & $\begin{array}{l}\text { UU No. 39/2004 hanya } \\
\text { mengatur contractual } \\
\text { worker (pekerja dengan } \\
\text { waktu tertentu sesuai } \\
\text { kontrak atau perjanjian } \\
\text { kerja) }\end{array}$ & $\begin{array}{l}\text { TKLN meliputi setiap warga negara } \\
\text { Indonesia yang bekerja di luar negeri } \\
\text { untuk waktu tertentu berdasarkan } \\
\text { kontrak kerja }\end{array}$ \\
\hline 3. & $\begin{array}{l}\text { Definisi disesuaikan } \\
\text { dengan perubahan } \\
\text { nomeklatur TKI menjadi } \\
\text { TKLN }\end{array}$ & $\begin{array}{l}\text { - Calon Tenaga Kerja Luar Negeri } \\
\text { (Calon TKLN) adalah setiap pencari } \\
\text { kerja yang akan bekerja ke luar negeri } \\
\text { dan terdaftar di Dinas Kabupaten/Kota } \\
\text { yang bertanggung jawab di bidang } \\
\text { Ketenagakerjaan } \\
\text { - Tenaga Kerja Luar Negeri (TKLN) } \\
\text { adalah calon TKLN yang telah } \\
\text { memenuhi syarat untuk bekerja di luar } \\
\text { negeri dalam hubungan kerja, baik yang } \\
\text { bekerja di darat, laut maupun udara } \\
\text { - TKLN Purna adalah TKLN yang telah } \\
\text { berakhir perjanjian kerjanya dan kembali } \\
\text { ke Indonesia/daerah asal }\end{array}$ \\
\hline 4. & $\begin{array}{l}\text { UU No.39/2004 (Pasal } \\
\text { 10) hanya menyebutkan } \\
\text { ada } 2 \text { pelaksana } \\
\text { penempatan yaitu } \\
\text { pemerintah dan PPTKIS. } \\
\text { Padahal TKI dapat } \\
\text { bekerja ke luar negeri } \\
\text { secara mandiri dan } \\
\text { ditempatkan oleh }\end{array}$ & $\begin{array}{l}\text { Ada } 4 \text { cara TKLN bekerja ke luar negeri: } \\
\text { a. Melalui pemerintah (G to G dan G to } \\
\text { P) } \\
\text { b. Melalui Swasta (PPTKIS) } \\
\text { c. Bekerja Mandiri } \\
\text { d. Ditempatkan oleh perusahaan untuk } \\
\text { kepentingan sendiri } \\
\text { Teknis penempatan TKLN huruf a }\end{array}$ \\
\hline
\end{tabular}




\begin{tabular}{|c|c|c|}
\hline & $\begin{array}{l}\text { perusahaan untuk } \\
\text { kepentingan sendiri }\end{array}$ & $\begin{array}{l}\text { sampai dengan d diatur dengan } \\
\text { Peraturan Pemerintah/Peraturan } \\
\text { Presiden }\end{array}$ \\
\hline 5. & $\begin{array}{l}\text { Selama ini banyak orang } \\
\text { yang bekerja ke luar } \\
\text { negeri melalui perbatasan } \\
\text { secara non prosedural }\end{array}$ & $\begin{array}{l}\text { Perlu pengaturan tersendiri bagi TKLN } \\
\text { yang bekerja melalui daerah perbatasan }\end{array}$ \\
\hline 6. & $\begin{array}{l}\text { UU No. 39/2004 } \\
\text { mengatur penempatan } \\
\text { TKI pada pengguna } \\
\text { perseorangan dilakukan } \\
\text { hanya melalui PPTKIS } \\
\text { dan agensi/mitra usaha di } \\
\text { luar negeri }\end{array}$ & $\begin{array}{l}\text { RUU akan mengatur mengenai TKI } \\
\text { yang bekerja sesuai dengan profesinya } \\
\text { dapat juga dilakukan oleh pemerintah, } \\
\text { selain PPTKIS, dengan persyaratan: } \\
\text { - sistem live out } \\
\text { - Sponsorship untuk izin tinggal oleh } \\
\text { perusahaan outsourcing negara } \\
\text { setempat } \\
\text { - Penempatan melalui perusahaan } \\
\text { outsourcing di luar negeri (perusahaan } \\
\text { harus diverifikasi dan diakreditasi oleh } \\
\text { perwakilan RI) }\end{array}$ \\
\hline 7. & $\begin{array}{l}\text { UU No. 39/2004 terjadi } \\
\text { tumpang tindih } \\
\text { kewenangan K/L dan } \\
\text { Pemerintah Provinsi, } \\
\text { Pemerintah } \\
\text { Kabupaten/Kota }\end{array}$ & $\begin{array}{l}\text { Perlu diatur secara jelas mengenai } \\
\text { peran/kewenangan } \\
\text { Kementerian/Lembaga dan Pemerintah } \\
\text { Provinsi/Kabupaten/Kota terkait dengan } \\
\text { penempatan dan perlindungan TKLN } \\
\text { Peran dan kewenangan K/L adalah } \\
\text { sebagai berikut: } \\
\text { 1. Kementerian Luar Negeri meliputi: } \\
\text { a. Upaya diplomatik } \\
\text { b. Membuat perjanjian } \\
\text { internasional/MoU } \\
\text { c. Melakukan market intelligent } \\
\text { 2. Perwakilan RI meliputi: } \\
\text { a. Melakukan promosi dan market } \\
\text { intelligent/mencari peluang kerja; } \\
\text { b. Melakukan pencatatan kedatangan } \\
\text { TKLN; } \\
\text { c. Welcoming program dan exit } \\
\text { program; } \\
\text { d. Pendaftaran dan akreditasi Mitra } \\
\text { Usaha; } \\
\text { e. Penilaian pengguna perseorangan } \\
\text { dan mitra usaha; } \\
\text { f. Membuat rating mitra usaha/agensi } \\
\text { luar negeri; } \\
\text { g. Membuat daftar mitra usaha dan }\end{array}$ \\
\hline
\end{tabular}




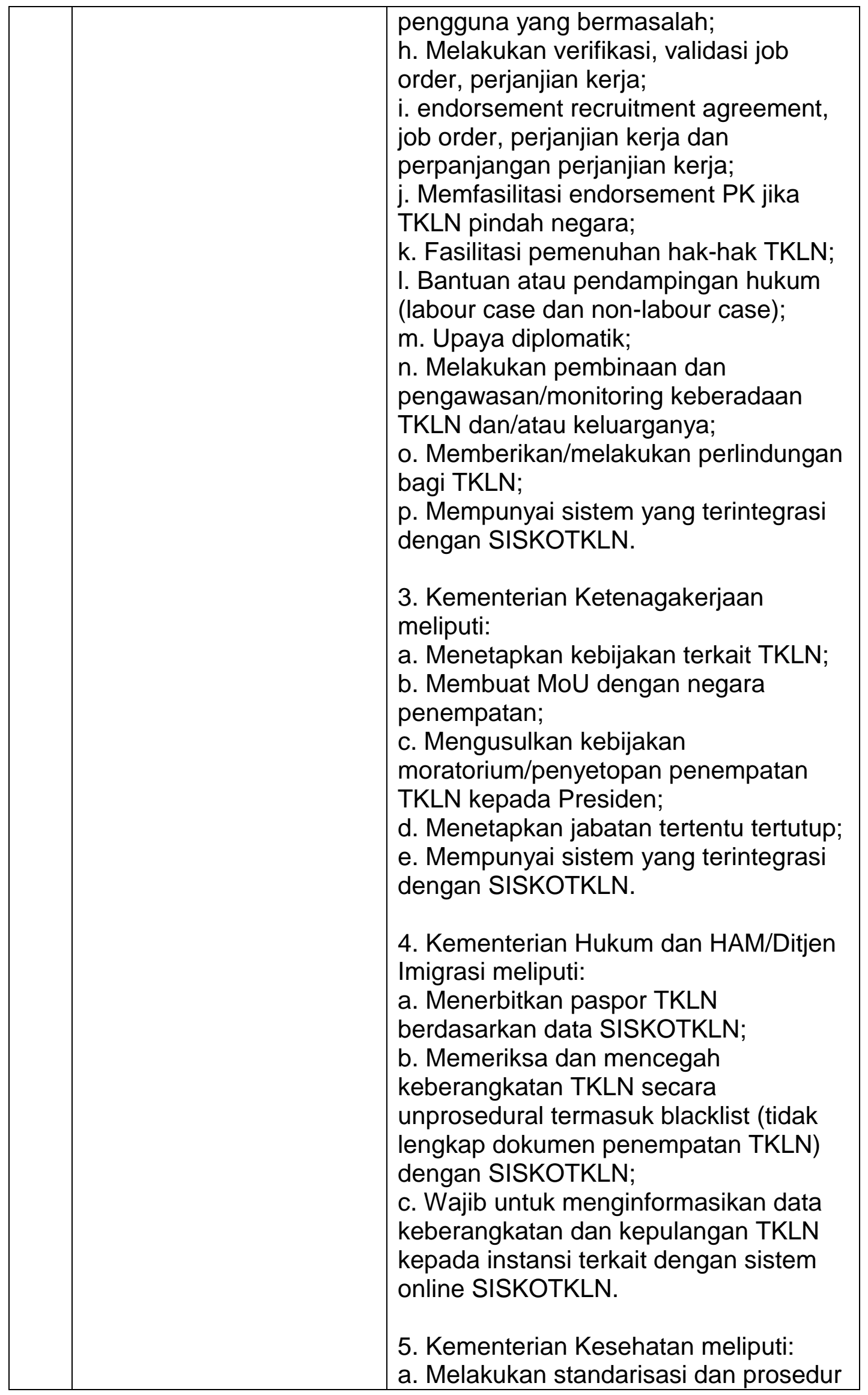




\begin{tabular}{|l|l|}
\hline & pemeriksaan kesehatan secara bilateral \\
maupun multilateral; \\
b. Menyatakan sarana kesehatan \\
(sarkes) yang melakukan pemeriksaan \\
kesehatan calon TKLN; \\
c. Menetapkan jenis-jenis pemeriksaan \\
kesehatan calon TKLN dan besarnya \\
biaya pemeriksa kesehatan; \\
d. Melakukan pembinaan, pengawasan \\
dan penjatuhan sanksi terhadap sarkes- \\
sarkes; \\
e. Mempunyai sistem yang terintegrasi \\
dengan SISKOTKLN. \\
6. Kementerian Dalam Negeri meliputi \\
data kependudukan (NIK). \\
7. Pemerintah Provinsi (Dinasi Tenaga \\
Kerja) meliputi: \\
a. Monitoring dan evaluasi penempatan \\
TKI ke luar negeri yang berasal dari \\
wilayah provinsi; \\
b. Fasilitasi pelaksanaan perjanjian \\
kerjasama bilateral/multilateral di \\
wilayah Kabupaten/Kota; \\
c. Rekomendasi perpanjangan \\
SIPPTKI-PPTKIS; \\
d. Merekomendasi jabatan-jabatan yang \\
ada di wilayahnya; \\
e. Pemetaan supply wilayah provinsi \\
(kompilasi dari kabupaten/kota); \\
f. Menyiapkan kompetensi SDM di \\
wilayah provinsi; \\
g. Pencegahan TKI ilegal; \\
h. Pemberantasan calo; \\
i. Penyebarluasan sistem informasi \\
penempatan; \\
j. Fasilitasi penyelenggaraan PAP; \\
k. Pembinaan dan pengawasan \\
terhadap kelembagaan penempatan di \\
wilayah provinsi; \\
I. Menerbitkan izin lembaga-lembaga \\
pelatihan; \\
m. Fasilitasi kepulangan TKI di \\
pelabuhan debarkasi di wilayah provinsi. \\
8. Pemerintah Kabupaten/Kota (Dinas \\
Tenaga Kerja dan Kependudukan)
\end{tabular}




\begin{tabular}{|c|c|c|}
\hline & & $\begin{array}{l}\text { meliputi: } \\
\text { a. Melakukan penyuluhan; } \\
\text { b. Melakukan pendataan calon TKLN; } \\
\text { c. Penyiapan kualitas SDM di } \\
\text { kabupaten/kota; } \\
\text { d. Melakukan pendaftaran dan verifikasi } \\
\text { calon TKLN; } \\
\text { e. Melakukan seleksi calon TKLN; } \\
\text { f. Penjelasan substansi perjanjian } \\
\text { penempatan; } \\
\text { g. Memberikan persetujuan perjanjian } \\
\text { penempatan; } \\
\text { h. Menerbitkan rekomendasi paspor; } \\
\text { i. Mengurus kepulangan TKLN sampai } \\
\text { ke daerah asal dalam hal terjadi perang, } \\
\text { bencana alam, wabah penyakit dan } \\
\text { deportasi; } \\
\text { j. Fasilitasi penyelesaian masalah } \\
\text { antara PPTKIS dan TKLN; } \\
\text { k. Memfasilitasi pelayanan perawatan } \\
\text { lanjutan bagi TKI B sakit; } \\
\text { I. Pengawasan terhadap } \\
\text { penyelenggaraan penempatan dan } \\
\text { perlindungan TKI; } \\
\text { m. Pencegahan/pemberantasan TKI } \\
\text { ilegal/unprosedural. } \\
\text { 9. Kepolisian meliputi: } \\
\text { a. Mengkoordinasikan dan mengawasi } \\
\text { penyelidikan dan penyidikan yang } \\
\text { dilakukan oleh PPNS BNP2TKI } \\
\text { terhadap tindak pidana terkait dengan } \\
\text { penempatan TKLN; } \\
\text { b. SKCK sesuai permintaan negara } \\
\text { penempatan. }\end{array}$ \\
\hline 8. & $\begin{array}{l}\text { Perlu penguatan fungsi } \\
\text { dan kewenangan } \\
\text { BNP2TKI }\end{array}$ & $\begin{array}{l}\text { Kewenangan BNP2TKI/BNTKLN } \\
\text { meliputi: } \\
\text { a. Membuat regulasi (peraturan } \\
\text { pelaksanaan dari UU dan Perpres) } \\
\text { b. Turut serta dalam pembahasan MoU } \\
\text { dengan negara penempatan } \\
\text { c. Melakukan promosi (bersama-sama } \\
\text { dengan perwakilan RI) } \\
\text { d. Penerbitan ljin Usaha (SIUP). Tata } \\
\text { cara penerbitan SIUP diatur dengan } \\
\text { Perpres (termasuk persyaratan } \\
\text { penerbitan SIUP); }\end{array}$ \\
\hline
\end{tabular}




\begin{tabular}{|l|l|}
\hline & e. Menetapkan LPP; \\
f. Penjatuhan sanksi administratif & (teguran, skorsing dan pencabutan \\
& SIUP). Tata cara penjatuhan sanksi \\
administratif diatur dengan peraturan & Kepala BNTKLN; \\
g. Membangun sistem informasi (sistem & online) yang terintegrasi dengan seluruh \\
K/L terkait dan semua stakeholders \\
(Kemenaker, Perwakilan RI, Perwakilan \\
Negara Penempatan di Indonesia, \\
Imigrasi, Kemenkes, Kependudukan, \\
Dinas Tenaga Kerja \\
Provinsi/Kabupaten/Kota, Kepolisian, \\
PPTKIS, BLKLN, LSP, LUK, LPP, \\
Asuransi, Sarana Kesehatan, Lembaga \\
Keuangan/Perbankan); \\
h. Pengawasan dan penyidikan oleh \\
PPNS; \\
i. Pembinaan terhadap lembaga \\
penempatan (PPTKIS, Sarkes, Asuransi \\
dan lain sebagainya); \\
j. Penempatan G to Gan G to P; \\
k. Meningkatkan kompetensi TKLN \\
(adjustment training); \\
I. Menerbitkan surat ijin perekrutan \\
(SIP); \\
m. Menetapkan cost structure, \\
- biaya penempatan harus dibedakan \\
antara TKLN baru dan TKLN eks; \\
- ketentuan komponen dan besarnya \\
biaya penempatan ditetapkan lebih \\
lanjut dengan peraturan Kepala Badan; \\
n. Menetapkan skema asuransi \\
(coverage), penyelenggara, nilai \\
pertanggungan, dst. \\
o. Membentuk unit pelayanan (UPT) di \\
daerah Provinsi/Kabupaten/Kota yang \\
diatur lebih lanjut dengan Peraturan \\
Kepala Badan; \\
p. Membentuk perwakilan di luar negeri \\
(seperti halnya POLO di Filipina); \\
q. Membuat instrumen perlindungan \\
(recruitment agreement, perjanjian \\
penempatan, PK) \\
r. Melaksanakan fungsi OWWA \\
(Overseas Worker Welfare \\
Administration); \\
\hline
\end{tabular}




\begin{tabular}{|l|l|l|}
\hline & & $\begin{array}{l}\text { S. Menyelesaikan masalah TKLN (pra, } \\
\text { masa dan purna kerja). }\end{array}$ \\
\hline 9. & $\begin{array}{l}\text { UU No.39/2004 hanya } \\
\text { mengatur isu } \\
\text { perlindungan secara } \\
\text { sumir } \\
\text { TKLN secara komprehensif. }\end{array}$ \\
& $\begin{array}{l}\text { 1. Perlindungan TKLN meliputi: } \\
\text { a. Pra-penempatan; } \\
\text { b. Masa penempatan; } \\
\text { c. Purna penempatan. } \\
\text { 2. Perlindungan Pra-Penempatan } \\
\text { meliputi: } \\
\text { a. Sosialisasi/diseminasi; } \\
\text { b. Peningkatan kompetensi (adjustment } \\
\text { training); } \\
\text { c. Pemenuhan kelengkapan dokumen } \\
\text { (paspor dipegang TKLN); } \\
\text { d. Penetapan biaya penempatan; } \\
\text { e. Penetapan kondisi dan syarat-syarat } \\
\text { kerja (gaji) dan cara pembayaran } \\
\text { (cashless), waktu kerja, waktu istirahat, } \\
\text { cuti, fasilitas, jaminan sosial/asuransi; } \\
\text { f. Pendampingan/bantuan hukum. } \\
\text { 3. Perlindungan Masa Penempatan } \\
\text { meliputi: } \\
\text { a. Pemberian bantuan atas pemenuhan } \\
\text { hak-hak TKLN (gaji dan cara } \\
\text { pembayaran (cashless), lembur, cuti); } \\
\text { b. Pembinaan (welcoming program dan } \\
\text { exit program, pertemuan rutin antara } \\
\text { pemerintah, TKLN, pengusaha dan } \\
\text { masyarakat); } \\
\text { c. Bantuan hukum; } \\
\text { d. Perlindungan kekonsuleran; } \\
\text { e. Akses komunikasi/informasi; } \\
\text { f. Upaya-upaya diplomatik; } \\
\text { g. Penyelesaian perselisihan/masalah } \\
\text { baik di dalam dan di luar negeri; }\end{array}$ \\
& $\begin{array}{l}\text { Perlindungan TKLN di luar negeri/masa } \\
\text { penempatan dilakukan oleh unit } \\
\text { pelayanan BNP2TKI/BNTKLN di luar } \\
\text { negeri yang dipimpin oleh Kepala } \\
\text { Perwakilan RI dan beranggotakan unsur } \\
\text { Kemenaker dan BNP2TKI/BNTKLN } \\
\text { 4. Perlindungan Purna Penempatan }\end{array}$ \\
\hline
\end{tabular}




\begin{tabular}{|c|c|c|}
\hline & & $\begin{array}{l}\text { meliputi: } \\
\text { a. Kemudahan dan fasilitasi kepulangan } \\
\text { TKLN sampai daerah asal; } \\
\text { b. Pengurusan klaim asuransi; } \\
\text { c. Rehabilitasi dan reintegrasi; } \\
\text { d. Pemberdayaan TKLN (pembinaan } \\
\text { usaha mandiri); } \\
\text { e. Penanganan TKLN sakit/fasilitasi } \\
\text { perawatan. } \\
\text { 5. Perlindungan terhadap TKLN Non } \\
\text { Prosedural } \\
\text { - Pemberian perlindungan terhadap } \\
\text { TKLN tetap memperhatikan kondisi } \\
\text { negara dan sistem hukum yang berlaku } \\
\text { di negara penempatan } \\
\text { - Pemerintah harus bertanggung jawab } \\
\text { terhadap perlindungan TKLN apapun } \\
\text { status hukumnya (sesuai Konvensi } \\
\text { PBB/UU No. } 6 \text { Tahun 2012) } \\
\text { - Pengaturan lebih lanjut tentang } \\
\text { pemberian perlindungan pra- } \\
\text { penempatan, masa penempatan dan } \\
\text { purna-penempatan diatur dengan } \\
\text { Peraturan Pemerintah/Peraturan } \\
\text { Presiden }\end{array}$ \\
\hline 10. & $\begin{array}{l}\text { Menghapus syarat } \\
\text { pendidikan minimal SMP } \\
\text { bagi calon TKI sesuai } \\
\text { dengan putusan MK }\end{array}$ & $\begin{array}{l}\text { Pendidikan minimal SMP bagi calon } \\
\text { TKLN tetap dipersyaratkan dalam RUU } \\
\text { dengan tujuan agar ada self protection } \\
\text { dan TKLN lebih bermartabat serta } \\
\text { dalam rangka melaksanakan UU wajib } \\
\text { belajar } 9 \text { tahun }\end{array}$ \\
\hline 11. & $\begin{array}{l}\text { Selama ini calon TKI } \\
\text { (PLRT) yang masuk } \\
\text { lembaga pelatihan belum } \\
\text { memiliki } \\
\text { keterampilan/kompetensi } \\
\text { sama sekali }\end{array}$ & $\begin{array}{l}\text { Calon TKLN yang direkrut harus sudah } \\
\text { memiliki kompetensi sesuai kualifikasi } \\
\text { negara tujuan penempatan. Apabila } \\
\text { kompetensi calon TKLN belum sesuai } \\
\text { dengan kualifikasi yang dipersyaratkan } \\
\text { oleh Pengguna, maka calon TKLN } \\
\text { harus mengikuti pelatihan (adjustment } \\
\text { training/upgrading skill) }\end{array}$ \\
\hline 12. & $\begin{array}{l}\text { Kantor cabang PPTKIS } \\
\text { melakukan tindakan } \\
\text { melebihi kewenangan } \\
\text { yang diatur oleh UU No. } \\
39 / 2004 \text { dan tidak }\end{array}$ & $\begin{array}{l}\text { Tidak perlu membentuk kantor cabang } \\
\text { PPTKIS, PPTKIS langsung merekrut } \\
\text { calon TKLN di Dinas Tenaga Kerja } \\
\text { Kabupaten/Kota (melalui SISKOTKLN) }\end{array}$ \\
\hline
\end{tabular}




\begin{tabular}{|l|l|l|}
\hline & $\begin{array}{l}\text { diketahui oleh kantor } \\
\text { pusat sehingga PPTKIS } \\
\text { tidak bertanggung jawab } \\
\text { atas apa yang dilakukan } \\
\text { kantor cabang }\end{array}$ & \\
\hline 13. & $\begin{array}{l}\text { Adanya wacana } \\
\text { penghapusan KTKLN }\end{array}$ & $\begin{array}{l}\text { KTKLN masih tetap diperlukan sebagai } \\
\text { bukti telah memenuhi persyaratan dan } \\
\text { prosedur yang berlaku }\end{array}$ \\
\hline 14. & $\begin{array}{l}\text { Moratorium/penutupan } \\
\text { penempatan ke negara } \\
\text { tertentu tidak } \\
\text { dikoordinasikan antara } \\
\text { instansi terkait }\end{array}$ & $\begin{array}{l}\text { Penetapan moratorium/penutupan ke } \\
\text { negara tertentu dilakukan oleh Presiden } \\
\text { RI }\end{array}$ \\
\hline III & $\begin{array}{l}\text { Lain-Lain } \\
1 .\end{array}$ & $\begin{array}{l}\text { Pembentukan Perwalu } \\
\text { PPTKIS sulit } \\
\text { dilaksanakan }\end{array}$ \\
\hline 2. & $\begin{array}{l}\text { Banyak TKI tidak } \\
\text { melaporkan kedatangan } \\
\text { dan kepulangan kepada } \\
\text { perwakilan RI }\end{array}$ & \\
\hline 3. & $\begin{array}{l}\text { Pencari kerja yang akan } \\
\text { bekerja ke luar negeri } \\
\text { tidak mendaftarkan diri } \\
\text { pada Dinas Tenaga Kerja } \\
\text { di Kabupaten/Kota }\end{array}$ & \\
\hline 4. & $\begin{array}{l}\text { Prinsip indemnity/tidak } \\
\text { boleh klaim ganda pada } \\
\text { asuransi }\end{array}$ & Asuransi perlu ditinjau kembali \\
\hline
\end{tabular}

Sumber: Diolah dari Materi Rapat 18 Mei 2015 di Hotel Harris yang diberikan oleh narasumber di BNP2TKI

Tabel 4.11 di atas memaparkan tiga bagian pokok dari dari RUU Perubahan UU No. 39 Tahun 2004 yakni bagian umum, isi/substansi RUU dan bagian lain-lain. Bagian umum menitikberatkan pada upaya penguatan RUU Perubahan UU No. 39 Tahun 2004 agar dapat menyelesaikan permasalahan TKI yang terjadi selama ini, koordinasi peran dan kewenangan Kementerian/Lembaga, upaya meminimalisasi blank mandat, pengarusutamaan isu HAM, pencegahan perdagangan manusia, upaya menghindari konflik kepentingan diantara para pejabat 
terkait dengan penempatan TKI, menyelesaikan dualisme dalam pengurusan TKI yang merugikan kepentingan TKI, serta merekomendasikan keterlibatan berbagai pihak seperti: KPK, BPK, Komnas HAM, Komisi Perlindungan Anak, Ombudsman, LSM dan Serikat Buruh yang bertujuan untuk perbaikan Tata Kelola TKI.

Bagian isi/substansi RUU mengkaji tentang istilah TKI yang dikonotasikan negatif, namun masih menyesuaikan dengan perubahan nomenklatuf yang disepakati, perluasan skop pelaksana penempatan TKI, pengaturan wewenang kementerian/lembaga (pemerintah pusat) pemerintah provinsi, dan pemerintah kabupaten/kota, penguatan fungsi dan kewenangan BNP2TKI, perlindungan TKI secara komprehensif di masa pra-penempatan, masa penempatan dan masa purna-penempatan, persyaratan minimal pendidikan calon TKI, persyaratan keterampilan/kompetensi TKI, hingga moratorium penempatan yang kurang dikoordinasikan dengan instansi terkait. Bagian lain-lain menyebutkan permasalahan terkait pembentukan perwakilan luar negeri PPTKIS yang sulit dilaksanakan, TKI yang tidak melaporkan kedatangan dan kepluangan di perwakilan RI, pencari kerja yang tidak terdaftar di Dinas Tenaga Kerja di daerah asal, serta klaim ganda yang terjadi pada asuransi TKI.

Kajian yang dilakukan oleh peneliti terhadap proses adopsi substansi konvensi internasional perlindungan hak pekerja migran melalui penelusuran RUU Perubahan UU No. 39 Tahun 2004. Draf RUU yang saat ini dibahas adalah RUU Perlindungan Pekerja Migran Indonesia 
(PPMI) versi Mei 2016 dari Kementerian Ketenagakerjaan RI, versi lainnya adalah RUU Perlindungan Pekerja Indonesia di Luar Negeri yang diperoleh dari WikiDPR tertanggal 27 Mei 2015 dan satu lagi RUU Perlindungan Pekerja Indonesia di Luar Negeri versi 29 Mei 2012. Jika membandingkan diantara ketiga draf RUU Perubahan UU No. 39 Tahun 2004 tersebut, maka draf RUU PPMI versi Mei 2016 yang telah mencantumkan UU No. 6 Tahun 2012 tentang Pengesahan Konvensi Internasional Perlindungan Hak Pekerja Migran dan Anggota Keluarganya dalam konsideran "Mengingat" pada poin 3 , setelah pada poin 1 disebutkan Undang-Undang Dasar Negara Republik Indonesia Tahun 1945 dan poin 2 disebutkan Undang-Undang No. 13 Tahun 2003 tentang Ketenagakerjaan. Sehingga, draf ini digunakan sebagai acuan untuk membandingkan dan menganalisis lebih lanjut apakah substansi konvensi internasional perlindungan hak pekerja migran telah diadopsi ke dalam RUU Perubahan UU No. 39 Tahun 2004. Hasil perbandingan dan analisis ditampilkan pada tabel 4.12 . 
Tabel 4.12 Adopsi Substansi Konvensi Internasional Perlindungan Hak Pekerja Migran dalam RUU Perubahan UU No. 39 Tahun 2004

\begin{tabular}{|c|c|c|c|}
\hline No. & $\begin{array}{l}\text { Muatan RUU Perubahan } \\
\text { UU No. } 39 \text { Tahun } 2004\end{array}$ & $\begin{array}{c}\text { Muatan Konvensi } \\
\text { (UU No.6 Tahun 2012) }\end{array}$ & Analisis \\
\hline 1 & $\begin{array}{l}\text { Pasal } 1 \text { Poin } 2 \text { Pekerja Migran Indonesia } \\
\text { adalah setiap warga negara Indonesia } \\
\text { yang akan, sedang atau telah melakukan } \\
\text { pekerjaan dengan menerima upah di luar } \\
\text { Negara Republik Indonesia }\end{array}$ & $\begin{array}{l}\text { Pasal } 2 \\
\text { Istilah "pekerja migran" mengacu } \\
\text { pada seseorang yang akan, tengah, } \\
\text { atau telah melakukan aktivitas yang } \\
\text { dibayar di suatu } \\
\text { Negara di mana ia bukan } \\
\text { merupakan warga negara; }\end{array}$ & $\begin{array}{l}\text { RUU Perubahan UU No. } 39 \text { Tahun } \\
2004 \text { mengadopsi secara penuh } \\
\text { definisi dari pekerja migran sesuai } \\
\text { dengan Konvensi }\end{array}$ \\
\hline 2. & $\begin{array}{l}\text { Pasal } 5 \\
\text { Ketentuan dalam Undang-Undang ini } \\
\text { tidak berlaku bagi: } \\
\text { a. WNI yang dikirim atau dipekerjakan } \\
\text { oleh badan-badan internasional atau } \\
\text { oleh negara di luar wilayahnya untuk } \\
\text { menjalankan tugas resmi; } \\
\text { b. Pelajar dan peserta pelatihan di luar } \\
\text { negeri; } \\
\text { c. WNI pengungsi atau pencari suaka; } \\
\text { d. Penanam modal atau investor; } \\
\text { e. Aparatur Sipil Negara atau lokal staf } \\
\text { yang bekerja di Perwakilan RI; } \\
\text { f. WNI yang bekerja pada institusi yang } \\
\text { dibiayai APBN; dan } \\
\text { g. WNI yang mempunyai usaha mandiri. }\end{array}$ & $\begin{array}{l}\text { Pasal } 3 \\
\text { Konvensi ini tidak boleh berlaku } \\
\text { bagi: } \\
\text { (a) orang-orang yang dikirim atau } \\
\text { dipekerjakan oleh organisasi } \\
\text { dan badan-badan internasional, atau } \\
\text { oleh suatu Negara di luar } \\
\text { wilayahnya untuk menjalankan } \\
\text { tugas resmi, yang kedatangan dan } \\
\text { statusnya diatur oleh hukum } \\
\text { internasional umum atau oleh } \\
\text { perjanjian internasional atau } \\
\text { konvensi khusus; } \\
\text { (b) orang-orang yang dikirim atau } \\
\text { dipekerjakan oleh suatu Negara } \\
\text { atau atas nama Negara di luar }\end{array}$ & $\begin{array}{l}\text { RUU Perubahan UU No. } 39 \text { Tahun } \\
2004 \text { mengadopsi dan } \\
\text { menyesuaikan dengan Konvensi } \\
\text { mengenai pembatasan ruang } \\
\text { lingkup pemberlakuan Undang- } \\
\text { Undang. }\end{array}$ \\
\hline
\end{tabular}




\begin{tabular}{|c|c|c|c|}
\hline & & $\begin{array}{l}\text { wilayahnya, yang berpartisipasi } \\
\text { dalam program pembangunan dan } \\
\text { program kerja sama lain, yang } \\
\text { kedatangan dan statusnya diatur } \\
\text { oleh perjanjian dengan Negara } \\
\text { tujuan kerja, dan yang sesuai } \\
\text { dengan perjanjian tersebut, tidak } \\
\text { dianggap sebagai pekerja migran; } \\
\text { (c) orang-orang yang bertempat } \\
\text { tinggal di Negara yang berbeda } \\
\text { dengan Negara asalnya sebagai } \\
\text { penanam modal; } \\
\text { (d) pengungsi atau orang tanpa } \\
\text { kewarganegaraan, kecuali } \\
\text { ketentuan tentang hal ini ditetapkan } \\
\text { dalam ketentuan hukum } \\
\text { nasional, atau dalam instrumen } \\
\text { internasional yang berlaku bagi } \\
\text { Negara Pihak tersebut; } \\
\text { (e) pelajar dan peserta pelatihan; } \\
\text { (f) pelaut dan pekerja pada suatu } \\
\text { instalasi lepas pantai yang } \\
\text { belum memperoleh izin tinggal dan } \\
\text { melakukan aktivitas yang } \\
\text { dibayar di Negara tujuan kerja. }\end{array}$ & \\
\hline 3. & $\begin{array}{l}\text { Pasal } 1 \text { Poin } 3 \\
\text { Keluarga adalah setiap orang atau } \\
\text { individu yang memiliki ikatan }\end{array}$ & $\begin{array}{l}\text { Pasal } 4 \\
\text { Untuk tujuan Konvensi ini, istilah } \\
\text { "anggota keluarga" mengacu }\end{array}$ & $\begin{array}{l}\text { Walaupun definisi mengenai } \\
\text { "Keluarga" yang tidak diadopsi } \\
\text { penuh dalam RUU Perubahan, }\end{array}$ \\
\hline
\end{tabular}




\begin{tabular}{|c|c|c|c|}
\hline & $\begin{array}{l}\text { kekerabatan karena daerah atau } \\
\text { kelahiran, pengangkatan atau } \\
\text { pengakuan, maupun karena putusan } \\
\text { pengadilan, menjadi bagian dari keluarga } \\
\text { pekerja migran Indonesia. }\end{array}$ & $\begin{array}{l}\text { pada orang-orang yang kawin } \\
\text { dengan pekerja migran atau } \\
\text { mempunyai hubungan dengannya, } \\
\text { yang menurut hukum yang } \\
\text { berlaku berakibat sama dengan } \\
\text { perkawinan, dan juga anak-anak } \\
\text { mereka yang menjadi tanggungan } \\
\text { dan orang-orang lain yang } \\
\text { menjadi tanggungan mereka yang } \\
\text { diakui sebagai anggota keluarga } \\
\text { berdasarkan ketentuan hukum yang } \\
\text { berlaku, atau menurut } \\
\text { perjanjian bilateral atau multilateral } \\
\text { antara Negara-Negara yang } \\
\text { bersangkutan. }\end{array}$ & $\begin{array}{l}\text { namun telah masuk dalam } \\
\text { ketentuan Konvensi. Hal ini penting } \\
\text { karena perbedaan mendasar antara } \\
\text { UU No. } 39 \text { Tahun } 2004 \text { dan RUU } \\
\text { Perubahannya terletak pada } \\
\text { dimasukkannya komponen keluarga } \\
\text { dalam Undang-Undang sebagai } \\
\text { konsekuensi dari ratifikasi Konvensi. }\end{array}$ \\
\hline 4. & $\begin{array}{l}\text { Pasal } 2 \\
\text { Perlindungan Pekerja Migran } \\
\text { berasaskan: } \\
\text { a. keterpaduan; } \\
\text { b. persamaan hak; } \\
\text { c. pengakuan atas martabat dan hak } \\
\text { asasi manusia; } \\
\text { d. demokrasi; } \\
\text { e. keadilan sosial } \\
\text { f. kesetaraan dan keadilan gender; } \\
\text { g. anti diskriminasi; } \\
\text { h. anti perdagangan manusia; } \\
\text { i. transparansi; }\end{array}$ & $\begin{array}{l}\text { Pasal } 7 \\
\text { Negara-Negara Pihak berupaya, } \\
\text { sesuai dengan instrument-instrumen } \\
\text { international tentang hak asasi } \\
\text { manusia, untuk menghormati dan } \\
\text { memastikan semua pekerja migran } \\
\text { dan anggota keluarganya dalam } \\
\text { wilayahnya atau yang tunduk pada } \\
\text { yuridiksinya memperoleh hak-hak } \\
\text { yang diatur dalam Konvensi ini } \\
\text { tanpa pembedaan apa pun seperti } \\
\text { jenis kelamin, ras, warna kulit, } \\
\text { bahasa, agama atau kepercayaan, }\end{array}$ & $\begin{array}{l}\text { Walaupun seluruh poin tidak } \\
\text { termasuk dalam Konvensi, namun } \\
\text { beberapa saja yang disebutkan } \\
\text { pada Bagian II Non-diskriminasi } \\
\text { dalam kaitan dengan hak yang } \\
\text { merupakan judul pembuka Pasal } 7 . \\
\text { Bagian ini sejalan dengan poin (b) } \\
\text { persamaan hak dan poin (g) anti } \\
\text { diskriminasi. Poin I perlindungan } \\
\text { terhadap privasi dari Pasal } 14 \\
\text { Konvensi Migran. Selain itu, poin } \\
\text { lainnya mengadopsi dari peraturan } \\
\text { terkait seperti: poin c pengakuan }\end{array}$ \\
\hline
\end{tabular}




\begin{tabular}{|c|c|c|c|}
\hline & $\begin{array}{l}\text { j. akuntabilitas; } \\
\text { k. berkelanjutan; } \\
\text { I. perlindungan terhadap privasi; dan } \\
\text { m. kepedulian dan keberpihakan }\end{array}$ & $\begin{array}{l}\text { pendapat politik atau lain-lain, } \\
\text { kebangsaan, asal-usul etnis atau } \\
\text { sosial, kewarganegaraan, usia, } \\
\text { kedudukkan ekonomi, kekayaan, } \\
\text { status perkawinan, status } \\
\text { kelahiran atau lain-lain. } \\
\text { Pasal } 14 \\
\text { Bebas dari bentuk intervensi } \\
\text { sewenang-wenang maupun di luar } \\
\text { hukum terhadap privasi yang } \\
\text { bersangkutan. }\end{array}$ & $\begin{array}{l}\text { atas martabat dan hak asasi } \\
\text { manusia dari UU No. } 39 \text { Tahun } 1999 \\
\text { tentang HAM, poin e keadilan sosial } \\
\text { dari UUD NRI } 1945 \text { dan UU No. } 11 \\
\text { Tahun } 2009 \text { tentang Kesejahteraan } \\
\text { Sosial, poin f kesetaraan dan } \\
\text { keadilan gender dari UU No. } 17 \\
\text { Tahun } 1984 \text { tentang Pengesahan } \\
\text { Konvensi CEDAW, maupun poin h } \\
\text { anti perdagangan manusia dari UU } \\
\text { No. } 21 \text { Tahun } 2007 \text { tentang } \\
\text { Pemberantasan Tindak Pidana } \\
\text { Perdagangan Manusia. }\end{array}$ \\
\hline 5. & $\begin{array}{l}\text { Pasal ... } \\
\text { Berdasarkan pertimbangan keamanan } \\
\text { dan perlindungan, pekerja migran } \\
\text { Indonesia di negara tujuan penempatan, } \\
\text { pemerintah menetapkan negara-negara } \\
\text { tertentu tertutup bagi penempatan PMI } \\
\text { dengan Peraturan Menteri }\end{array}$ & $\begin{array}{l}\text { Pasal } 8 \text { Ayat } 1 \\
\text { Para pekerja migran dan anggota } \\
\text { keluarganya harus bebas } \\
\text { untuk meninggalkan negara mana } \\
\text { pun, termasuk negara asal } \\
\text { mereka. Hak ini tidak boleh dibatasi } \\
\text { kecuali sebagaimana } \\
\text { ditetapkan oleh hukum, diperlukan } \\
\text { untuk melindungi keamanan } \\
\text { nasional, ketertiban umum, } \\
\text { kesehatan dan moral umum, atau } \\
\text { hak-hak dan kebebasan-kebebasan } \\
\text { orang lain, dan yang sesuai dengan } \\
\text { hak-hak lain yang diakui dalam } \\
\text { Konvensi ini. }\end{array}$ & $\begin{array}{l}\text { Negara tujuan penempatan PMI } \\
\text { dapat ditutup melalui Peraturan } \\
\text { Menteri, hal ini sejalan dengan } \\
\text { Konvensi yang menyatakan hak PMI } \\
\text { untuk bebas keluar masuk, kecuali } \\
\text { pada kasus-kasus yang ditentukan } \\
\text { oleh Undang-Undang. }\end{array}$ \\
\hline
\end{tabular}




\begin{tabular}{|c|c|c|c|}
\hline 6. & $\begin{array}{l}\text { Pasal } 11 \\
\text { Perlindungan yang dilakukan oleh } \\
\text { pemerintah adalah untuk menjamin } \\
\text { pemenuhan hak-hak pekerja migran } \\
\text { Indonesia berdasarkan hukum nasional, } \\
\text { hukum negara setempat dan hukum } \\
\text { internasional yang meliputi: } \\
\text { a. hak untuk mendapatkan pekerjaan di } \\
\text { luar negeri dan memilih pekerjaan sesuai } \\
\text { dengan kompetensinya; } \\
\text { b. hak untuk memperoleh akses } \\
\text { peningkatan kapasitas diri melalui } \\
\text { pelatihan; } \\
\text { c. hak untuk memperoleh informasi yang } \\
\text { benar mengenai pasar kerja, tata cara } \\
\text { penempatan dan kondisi kerja di luar } \\
\text { negeri; } \\
\text { d. hak untuk memperoleh pelayanan } \\
\text { yang profesional, transparan dan } \\
\text { manusiawi, perlakuan tanpa diskriminasi, } \\
\text { serta anti perdagangan manusia selama } \\
\text { masa pra-penempatan, masa } \\
\text { penempatan dan purna penempatan; } \\
\text { e. hak untuk menjalankan ibadah sesuai } \\
\text { agama dan keyakinan yang dianut; } \\
\text { f. hak untuk memperoleh perlindungan } \\
\text { dan bantuan hukum atas tindakan yang } \\
\text { dapat merendahkan harkat dan martabat }\end{array}$ & $\begin{array}{l}\text { Pasal } 12 \text { Poin } 1 \\
\text { Para pekerja migran dan anggota } \\
\text { keluarganya harus memiliki } \\
\text { hak atas kebebasan berpikir, } \\
\text { berkeyakinan, dan beragama. } \\
\text { Pasal } 14 \\
\text { Tidak seorang pun pekerja migran } \\
\text { atau anggota keluarganya boleh } \\
\text { secara sewenang-wenang atau } \\
\text { secara tidak sah diganggu dalam hal } \\
\text { urusan pribadi, keluarga, rumah } \\
\text { tangga, korespondensi, atau } \\
\text { komunikasi lain, atau secara tidak } \\
\text { sah diserang kehormatan dan } \\
\text { nama baiknya. } \\
\text { Pasal } 15 \\
\text { Tidak seorang pun pekerja migran } \\
\text { atau anggota keluarganya boleh } \\
\text { secara sewenang-wenang dirampas } \\
\text { harta bendanya, baik yang } \\
\text { dimiliki sendiri maupun bersama- } \\
\text { sama dengan orang lain. Apabila } \\
\text { menurut ketentuan hukum yang } \\
\text { berlaku di Negara tujuan kerja, } \\
\text { aset pekerja migran atau anggota } \\
\text { keluarganya disita baik sebagian }\end{array}$ & $\begin{array}{l}\text { Pasal } 11 \text { RUU Perubahan yang } \\
\text { merupakan bagian dari Bab IV } \\
\text { Perlindungan Hak Pekerja Migran } \\
\text { Indonesia dan Keluarganya, } \\
\text { walaupun tidak mengadopsi } \\
\text { keseluruhan dari Konvensi, namun } \\
\text { ada keterkaitan antara beberapa } \\
\text { pasal yang teridentifikasi merujuk } \\
\text { pada substansi konvensi sebagai } \\
\text { berikut: } \\
\text { Pasal } 11 \text { Poin e tentang hak } \\
\text { menjalankan ibadah sesuai } \\
\text { keyakinan merujuk pada Pasal } 12 \\
\text { Poin } 1 \text { Konvensi tentang hak pekerja } \\
\text { migran atas kebebasan berpikir, } \\
\text { berkeyanin dan beragama. } \\
\text { Pasal } 11 \text { poin h tentang hak untuk } \\
\text { memperoleh akses berkomunikasi } \\
\text { merujuk pada Pasal } 14 \text { Konvensi } \\
\text { tentang larangan untuk menganggu } \\
\text { urusan pribadi atau komunikasi lain. } \\
\text { Pasal } 11 \text { poin k tentang hak untuk } \\
\text { menerima seluruh harta benda } \\
\text { pekerja migran Indonesia yang } \\
\text { meninggal di luar negeri mengacu }\end{array}$ \\
\hline
\end{tabular}




\begin{tabular}{|c|c|c|}
\hline $\begin{array}{l}\text { sesuai dengan peraturan perundang- } \\
\text { undangan di Indonesia dan di negara } \\
\text { tujuan penempatan; } \\
\text { g. hak untuk mengetahui hak dan } \\
\text { kewajiban sebagaimana tertuang dalam } \\
\text { perjanjian kerja; } \\
\text { h. hak untuk memperoleh akses } \\
\text { berkomunikasi; } \\
\text { i. hak untuk memperoleh informasi } \\
\text { mengenai kondisi, masalah dan } \\
\text { kepulangan pekerja migran Indonesia; } \\
\text { j. hak untuk memperoleh salinan } \\
\text { dokumen dan perjanjian kerja calon } \\
\text { pekerja migran Indonesia/pekerja migran } \\
\text { Indonesia; dan } \\
\text { k. hak untuk menerima seluruh harta } \\
\text { benda pekerja migran Indonesia yang } \\
\text { meninggal di luar negeri. }\end{array}$ & $\begin{array}{l}\text { maupun seluruhnya, orang yang } \\
\text { bersangkutan harus memiliki hak } \\
\text { untuk memperoleh kompensasi } \\
\text { yang adil dan memadai. } \\
\text { Pasal } 33 \\
\text { 1. Para pekerja migran dan anggota } \\
\text { keluarganya harus memiliki } \\
\text { hak untuk diberi tahu oleh Negara } \\
\text { asal, Negara tujuan kerja, atau } \\
\text { Negara transit mengenai : } \\
\text { (a) hak-hak mereka yang } \\
\text { ditimbulkan oleh Konvensi ini; } \\
\text { (b) ketentuan mengenai } \\
\text { penerimaan, hak-hak dan kewajiban } \\
\text { mereka menurut hukum dan praktik } \\
\text { di Negara yang } \\
\text { bersangkutan serta hal lain yang } \\
\text { serupa yang memungkinkan } \\
\text { mereka untuk menaati ketentuan } \\
\text { administratif dan ketentuan } \\
\text { lain di Negara tersebut. } \\
\text { 2. Negara-Negara Pihak wajib } \\
\text { mengambil seluruh kebijakan yang } \\
\text { mereka anggap tepat untuk } \\
\text { menyebarluaskan informasi tersebut } \\
\text { di atas, atau untuk memastikan } \\
\text { bahwa informasi itu telah }\end{array}$ & $\begin{array}{l}\text { pada Pasal } 15 \text { tentang larangan } \\
\text { untuk merampas harta benda } \\
\text { pekerja migran dan anggota } \\
\text { keluarganya. } \\
\text { Pasal } 11 \text { poin g tentang hak untuk } \\
\text { mengetahui hak dan kewajiban } \\
\text { sebagaimana tertuang dalam } \\
\text { perjanjian kerja mengacu pada } \\
\text { Pasal } 33 \text { tentang hak pekerja migran } \\
\text { untuk diberitahu oleh negara asal, } \\
\text { negara tujuan kerja atau negara } \\
\text { transit mengenai hak dan kewajiban } \\
\text { mereka menurut hukum dan praktik } \\
\text { di negara yang bersangkutan, } \\
\text { utamanya yang menyangkut } \\
\text { ketentuan administratif. }\end{array}$ \\
\hline
\end{tabular}




\begin{tabular}{|c|c|c|c|}
\hline & & $\begin{array}{l}\text { diberikan oleh majikan, serikat } \\
\text { pekerja dan badan-badan atau } \\
\text { lembaga-lembaga lain yang sesuai. } \\
\text { Jika perlu, mereka wajib } \\
\text { bekerja sama dengan Negara- } \\
\text { Negara lain yang bersangkutan. } \\
\text { 3. Informasi yang memadai tersebut } \\
\text { wajib diberikan atas } \\
\text { permintaan pekerja migran dan } \\
\text { anggota keluarganya secara cuma- } \\
\text { cuma, dan sejauh dimungkinkan } \\
\text { dalam bahasa yang mereka } \\
\text { pahami. }\end{array}$ & \\
\hline 7. & $\begin{array}{l}\text { Pasal } 12 \\
\text { (1) Perlindungan pekerja migran } \\
\text { Indonesia masa penempatan adalah } \\
\text { segala upaya yang dilakukan oleh } \\
\text { perwakilan RI untuk membantu dan } \\
\text { melindungi kepentingan pekerja migran } \\
\text { Indonesia sejak saat tiba di Negara } \\
\text { penerima sampai kepulangan ke tanah } \\
\text { air; } \\
\text { (2) Perlindungan pekerja migran } \\
\text { Indonesia dilakukan dengan tidak } \\
\text { mengambil alih tanggungjawab pidana } \\
\text { dan.atau perdata sesuai dengan } \\
\text { peraturan perundang-undangan }\end{array}$ & $\begin{array}{l}\text { Pasal } 16 \text { Ayat } 7 \\
\text { Apabila seorang pekerja migran dan } \\
\text { anggota keluarganya } \\
\text { ditangkap atau dipenjara atau } \\
\text { ditahan selama menunggu untuk } \\
\text { diadili atau ditahan dalam bentuk } \\
\text { lain: } \\
\text { (a) pejabat konsuler atau diplomatik } \\
\text { Negara asalnya atau Negara yang } \\
\text { mewakili kepentingan Negara } \\
\text { tersebut wajib diberitahukan dengan } \\
\text { segera penangkapan atau } \\
\text { penahanan tersebut serta alasan- } \\
\text { alasannya, apabila yang }\end{array}$ & $\begin{array}{l}\text { Pasal } 16 \text { Ayat } 7 \text { dan juga pasal- } \\
\text { pasal terkait dengan permasalahan } \\
\text { hukum yang dihadapi oleh pekerja } \\
\text { migran di negara tujuan kerja } \\
\text { diadopsi ke dalam RUU Perubahan } \\
\text { UU No. } 39 \text { Tahun } 2004 \text { dalam } \\
\text { bentuk kewajiban bagi negara } \\
\text { pengirim (Indonesia) untuk } \\
\text { memberikan perlindungan terhadap } \\
\text { pekerja migrannya di negara } \\
\text { penempatan melalui perwakilannya } \\
\text { (Perwakilan RI). Walau demikian } \\
\text { pada Pasal } 12 \text { ayat } 2 \text { ditekankan } \\
\text { bahwa perlindungan hak diberikan }\end{array}$ \\
\hline
\end{tabular}




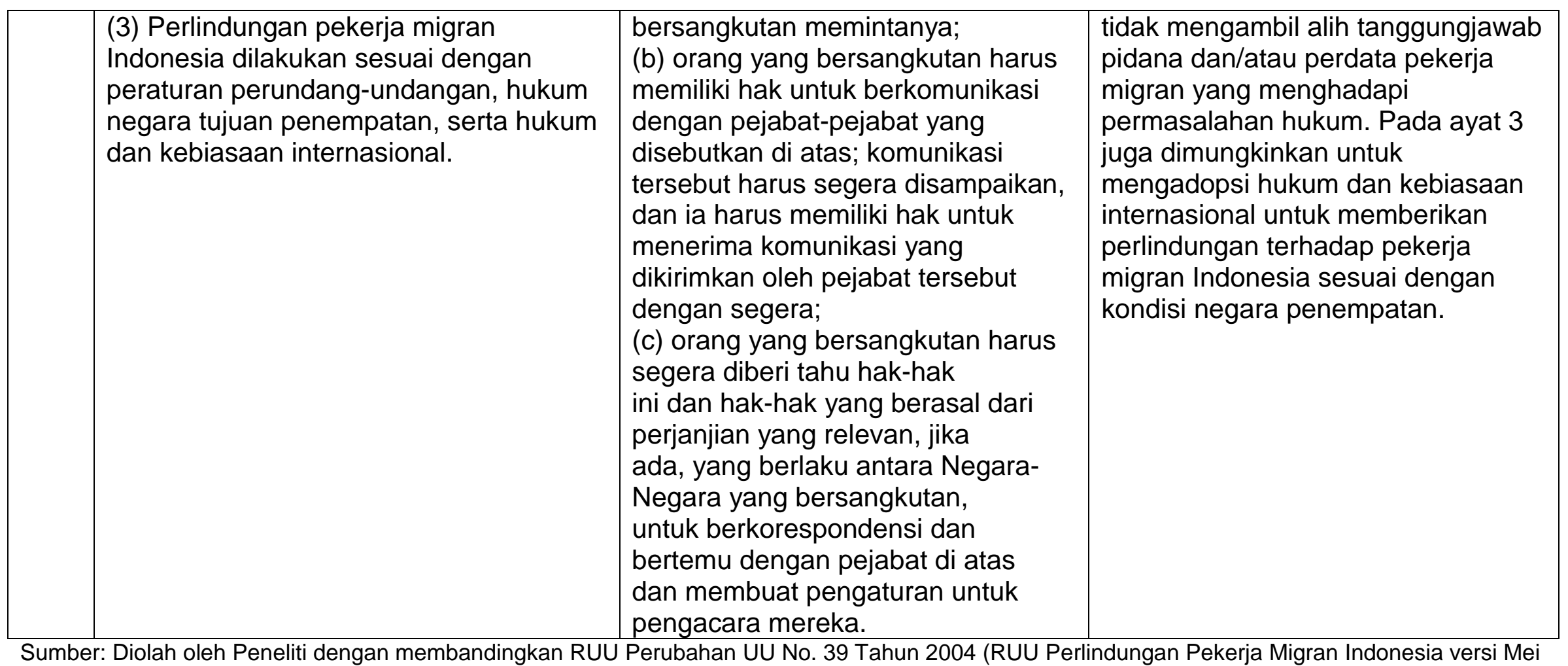

2016 dengan lampiran UU No. 6 Tahun 2012 tentang pengesahan Konvensi Internasional Perlindungan Hak Pekerja Migran dan Anggota Keluarganya 
Tabel 4.12 di atas berupaya mengidentifikasi substansi konvensi dari UU No. 6 Tahun 2012 dengan draf RUU Perubahan UU No. 39 Tahun 2004 yang telah mengacu pada Konvensi. Hasil analisis dari Tabel 4.12 di atas menunjukkan terdapat 7 temuan yang menunjukkan bahwa RUU Perubahan UU No. 39 Tahun 2004 telah mengadopsi substansi konvensi. Temuan pertama mengenai definisi pekerja migran yang mengadopsi secara penuh definisi dari Konvensi ke dalam RUU Perubahan. Temuan kedua mengenai pembatasan ruang lingkun pemberlakuan UndangUndang yang mengadopsi dari batasan ruang lingkup ketentuan Konvensi. Temuan ketiga mengenai definisi "Keluarga", walaupun tidak mengadopsi secara penuh definisi dari Konvensi tetapi substansi definisi telah masuk dalam ketentuan Konvensi. Temuan keempat mengenai asas perlindungan pekerja migran Indonesia mengadopsi nilai-nilai dari Konvensi terutama asas persamaan hak dan asas anti diskriminasi, serta asas perlindungan terhadap privasi. Selebihnya berkaitan dengan peraturan terkait yang berasal dari hukum nasional.

Selanjutnya, temuan kelima mengenai wewenang pemerintah untuk menutup akses ke negara tujuan penempatan dengan pertimbangan keamanan dan perlindungan sesuai dengan pembolehan dalam konvensi untuk membatasi hak PMI untuk bebas keluar masuk sesuai dengan yang ditentukan oleh Undang-Undang/Peratuan dari negara asal. Temuan keenam mengenai perlindungan hak pekerja migran Indonesia dan keluarganya yang terkait antara Konvensi dan RUU Perubahan antara lain: hak menjalankan ibadah, hak untuk memperoleh akses 
berkomunikasi, hak untuk menerima seluruh harta benda pekerja migran Indonesia yang meninggal di luar negeri maupun hak untuk mengetahui hak dan kewajiban pekerja migran. Temuan ketujuh mengenai kewajiban pemerintah Indonesia untuk memberikan perlindungan terhadap pekerja migrannya di negara penempatan melalui perwakilan, namun demikian pekerja migran yang bermasalah tetap mempertanggungjawabkan urusan pidana dan/atau perdata-nya secara pribadi.

Secara umum RUU Perubahan UU No. 39 Tahun 2004 telah mengadopsi substansi Konvensi (UU No. 6 Tahun 2012), baik melalui adopsi tertulis maupun adopsi nilai. Secara tertulis telah dipaparkan pada bagian sebelumnya bahwa ada 7 temuan dengan membandingkan di antara keduanya. Sedangkan adopsi nilai terlihat dari struktur RUU Perubahan yang menekankan konteks Perlindungan dan pelibatan Anggota Keluarga dalam substansi Undang-Undang. Konteks perlindungan dapat dilihat dari 4 Bab yang mengawali dengan kata Perlindungan antara lain: Bab IV Perlindungan Hak Pekerja Migran Indonesia dan Keluarganya, Bab V Perlindungan Pra Penempatan, Bab VI Perlindungan Masa Penempatan dan Bab VII Perlindungan Purna Penempatan. Sedangkan frasa Anggota Keluarga/Keluarga ditemukan di beberapa pasal dan poin dalam Undang-Undang. Hal yang merupakan kemajuan dari proses adopsi substansi ini yakni dimasukkannya hukum kebiasaan internasional sebagai rujukan dalam Undang-Undang, seperti: "Perlindungan Pekerja Migran Indonesia dilakukan sesuai dengan 
peraturan perundang-undangan, hukum negara tujuan penempatan serta hukum dan kebiasaan internasional".

Berdasarkan penjelasan di atas, maka dapat disimpulkan bahwa proses adopsi substansi konvensi internasional perlindungan hak pekerja migran telah melalui dua proses yakni proses politik dan proses hukum. Proses politik telah berlangsung sejak masa bakti DPR RI periode 20092014 dan masuk dalam Program Legislasi Nasional (Prolegnas), namun tidak selesai pada periode tersebut. Proses tersebut dilanjutkan pada masa bakti DPR RI periode 2009-2014 yang juga masuk dalam Prolegnas. Pernyataan yang menyiratkan bahwa akan dilakukannya harmonisasi Konvensi (UU No. 6 Tahun 2012) baru dinyatakan dan terdokumentasi dalam Rapat antara Komisi IX dan Pemerintah pada 19 Januari 2016. Di samping itu, upaya dari organisasi masyarakat sipil juga dilakukan melalui aksi maupun diskusi yang menuntut pemerintah untuk mengadopsi Konvensi ke dalam Undang-Undang.

Proses hukum juga dilakukan untuk mengadopsi substansi konvensi. Peneliti menemukan substansi konvensi mulai muncul dalam naskah akademik RUU Perlindungan Pekerja Indonesia di Luar Negeri versi 7 Juni 2012, namun demikian dalam Rancangan UndangUndangnya belum ditemukan UU pengesahan Konvensi dimasukkan sebagai rujukan. Selain itu, tuntutan untuk adopsi substansi Konvensi juga dilakukan oleh Perhimpunan Indonesia untuk Buruh Migran Berdaulat (LSM Migrant Care) melalui 16 poin perubahan yang berbasis prinsipprinsip Konvensi ILO dan Konvensi Buruh Migran. Pemerintah juga 
menyusun pokok-pokok pikiran RUU Perubahan UU No. 39 Tahun 2004, namun tidak menyebutkan secara spesifik substansi yang diadopsi dari Konvensi, namun lebih menitikberatkan pada penataan Kementerian/Lembaga yang berwenang. Peneliti berupaya untuk mengkaji lebih mendalam melalui perbandingan antara draf RUU Perubahan UU No. 39 Tahun 2004 versi Mei 2016 yang telah merujuk pada Konvensi dengan lampiran UU No. 6 Tahun 2012 tentang pengesahan Konvensi. Peneliti menemukan secara umum perubahan UU No. 39 Tahun 2004 telah mengadopsi substansi Konvensi melalui adopsi tertulis maupun adopsi nilai. Adopsi tertulis teridentifikasi 7 temuan, sedangkan adopsi nilai teridentifikasi melalui konteks perlindungan dan pelibatan anggota keluarga dalam substansi Undang-Undang, serta rujukan terhadap hukum kebiasaan internasional dalam memberikan perlindungan terhadap pekerja migran Indonesia. 


\section{BAB V \\ PENUTUP}

\section{A. Kesimpulan}

Berdasarkan pemaparan dalam bab-bab terdahulu, maka penelitian ini menyimpulkan bahwa:

1. Harmonisasi konvensi internasional perlindungan hak pekerja migran dengan UU No. 39 Tahun 2004 dilakukan melalui proses transformasi yang mengacu pada kedudukan konvensi internasional dalam hukum nasional Indonesia. UU No. 39 Tahun 2004 mengalami disharmonis karena orientasi Undang-Undang masih pada pengaturan penempatan dibadingkan perlindungan. Sehingga, diperlukan pendalaman substansi konvensi untuk memberikan perlindungan bagi seluruh pekerja Indonesia di luar negeri.

2. Substansi konvensi internasional perlindungan hak pekerja migran diadopsi melalui dua proses yakni proses politik melalui pembahasan RUU Perubahan UU No. 39 Tahun 2004 di DPR RI serta keterlibatan organisasi masyarakat sipil dan proses hukum dengan dirujuknya UU No. 6 Tahun 2012 pada RUU Perubahan UU No. 39 Tahun 2004 versi Mei 2016 dan diidentifikasi 7 temuan yang membandingkan RUU Perubahan dan UU pengesahan konvensi. Serta konteks perlindungan dan pelibatan anggota keluarga yang telah diharmonisasi dalam substansi UU. 


\section{B. Saran}

1. Bagi pemerintah agar dapat segera menyelesaikan pembahasan Rancangan Undang-Undang Perubahan Undang-Undang Nomor 39 Tahun 2004 dengan mengacu pada itikad politik hukum pemerintah Indonesia yakni menjalankan komitmen pemerintah terhadap pemajuan nilai-nilai hak asasi manusia, termasuk didalamnya hak pekerja migran dan mencerminkan prioritas pemerintah untuk memberikan perlindungan terhadap hak-hak pekerja migran Indonesia dapat diwujudkan.

2. Bagi pemerintah agar lebih mendalami substansi Konvensi Internasional Perlindungan Hak Pekerja Migran (UU No. 6 Tahun 2012) untuk mengoptimalkan perlindungan pekerja migran Indonesia yang mengacu pada standar-standar HAM internasional yang diatur dalam Konvensi dan bersesuaian dengan norma hukum Indonesia. 


\section{DAFTAR PUSTAKA}

Buku

Agusmidah. 2011. Dilematika Hukum Ketenagakerjaan: Tinjauan Politik Hukum. Medan: PT. Sofmedia.

Ahmad Erani Yustika. 2009. Ekonomi Politik: Kajian Teoretis dan Analisis Empiris. Yogyakarta: Pustaka Pelajar.

Andrew T. Guzman. 2008. How International Law Works: A Rational Choice Theory. New York: Oxford University Press.

Anthonius P. Sitepu. 2011. Studi Hubungan Internasional. Yogyakarta: Graha IImu.

Aziz Syamsuddin. 2013. Proses \& Teknik Penyusunan UndangUndang Edisi Kedua. Jakarta: Sinar Grafika.

Boer Mauna. 2011. Hukum Internasional Pengertian Peranan dan Fungsi dalam Era Dinamika Global. Bandung: PT. Alumni.

Dahlan Thaib. 1996. Kedaulatan Rakyat Negara Hukum dan Hak-hak Asasi Manusia. Jakarta: Media Pratama.

Damos Dumoli Agusman. 2010. Hukum Perjanjian Internasional: Kajian Teori dan Praktik Indonesia. Bandung: Refika Aditama.

Damos Dumoli Agusman. 2014. Treaties Under Indonesian Law: A Comparative Study. Bandung: Remaja Rosdakarya.

David J. Bederman. 2002. The Spirit of International Law. Athens: University of Georgia Press.

Dedi Supriyadi. 2013. Hukum Internasional: Dari Konsepsi sampai Aplikasi. Bandung: Pustaka Setia.

Deliarnov. 2006. Ekonomi Politik. Jakarta: Penerbit Erlangga.

Didik J. Rachbini. 2001. Analisis Kritis Ekonomi Politik Indonesia. Yogyakarta: Pustaka Pelajar.

Didik Sukriono Sirajuddin dan Winardi. 2011. Hukum Pelayanan Publik berbasis Keterbukaan Informasi dan Partisipasi. Malang: Setara Press.

Dwiyanto Indiahono. 2009. Kebijakan Publik Berbasis Dynamic Policy Analysis. Yogyakarta: Penerbit Gava Media. 
Eddy Pratomo. 2016. Hukum Perjanjian Internasional: Dinamika dan Tinjauan Kritis terhadap Politik Hukum Indonesia. Jakarta: PT. Elex Media Komputindo.

Edi Suharto. 2012. Analisis Kebijakan Publik: Panduan Praktis Mengkaji Masalah dan Kebijakan Sosial. Bandung: Penerbit Alfabeta.

Erwan Agus Purwanto dan Dyah Ratih Sulistyastuti. 2012. Implementasi Kebijakan Publik: Konsep dan Aplikasinya di Indonesia. Yogyakarta: Penerbit Gava Media.

Faried Ali dan Andi Syamsu Alam. 2012. Studi Kebijakan Pemerintah. Bandung: Refika Aditama.

Faried Ali, Andi Syamsu Alam, dan Sastro M. Wantu. 2012. Studi Analisa Kebijakan: Konsep, Teori dan Aplikasi Sampel Teknik Analisa Kebijakan Pemerintah. Bandung: Refika Aditama.

Frank Fischer, Gerald J. Miller dan Mara S. Sidney. 2015. Handbook Analisis Kebijakan Publik (terj.). Bandung: Penerbit Nusa Media.

Gatot Supramono. 2012. Hukum Orang Asing di Indonesia. Jakarta: Sinar Grafika.

Hans J. Morgenthau. 1999. Politik Antar Bangsa. Terjemahan Cecep Sudrajat direvisi oleh J.Thomson Buku III. Jakarta: Yayasan Obor Indonesia.

Henry Campbell Black et., al.1991. Black Law Dictionary with Pronounciations. St. Paul, Minn: West Publishing Co.

Ismantoro Dwi Yuwono. 2011. Hak dan Kewajiban Tenaga Kerja Indonesia di Luar Negeri. Yogyakarta: Penerbit Pustaka Yustisia.

I Wayan Parthiana. 2015. Hukum Pidana Internasional. Bandung: Yrama Widya.

Jack L. Goldsmith dan Eric A. Posner. 2005. The Limits of International Law. New York: Oxford University Press.

James A. Caporaso dan David P. Levine. 2008. Teori-Teori Ekonomi Politik. Yogyakarta: Pustaka Pelajar.

Jawahir Thontowi. 2016. Hukum dan Hubungan Internasional. Yogyakarta: UII Press. 
Jimly Asshiddiqie. 2005. Hukum Tata Negara dan Pilar-Pilar Demokrasi: Serpihan Pemikiran Media, Hukum dan HAM. Jakarta: Konstitusi Press.

Jimly Asshiddiqie. 2010. Konstitusi \& Konstitusionalisme Indonesia. Bandung: Sinar Grafika.

Jimly Asshiddiqie. 2006. Pengantar IImu Hukum Tata Negara Jilid I. Jakarta: Sekretariat Jenderal dan Kepaniteraan Mahkamah Konstitusi RI.

Jimly Asshiddiqie. 2006. Perkembangan dan Konsolidasi Lembaga Negara Pasca Reformasi. Jakarta: Sekretariat Jenderal dan Kepaniteraan Mahkamah Konstitusi RI.

Kusnu Goesniadhie. 2006. Harmonisasi Hukum dalam Perspektif Perundang-undangan: Lex Specialis Suatu Masalah. Surabaya; JP Books.

Kusnu Goesniadhie. 2010. Harmonisasi Sistem Hukum: Mewujudkan Tata Pemerintahan yang Baik. Malang: Nasa Media.

La Ode Husen. 2009. Negara Hukum, Demokrasi dan Pemisahan Kekuasaan. Makassar: UMIToha Ukhuwah Grafika.

Lalu Husni. 2012. Pengantar Hukum Ketenagakerjaan Indonesia. Jakarta: Rajawali Pers.

Leo Agustino. 2012. Dasar-Dasar Kebijakan Publik. Bandung: Penerbit Alfabeta Bandung.

M. Gaussyah dkk. 2012. Menagih Janji Ratifikasi: Analisis Terhadap Ratifikasi Empat Konvensi Internasional di Bidang HAM. Jakarta: Kemitraan Partnership.

Mahmud F. Rakasima dkk. 2012. Seratus TKI Sukses. Jakarta: BNP2TKI.

Majda El Muhtaj. 2013. Dimensi-Dimensi HAM: Mengurai Hak Ekonomi, Sosial dan Budaya. Jakarta: Rajawali Pers.

Makarim Wibisono. 2006. Tantangan Diplomasi Multilateral. Jakarta: Pustaka LP3ES Indonesia.

Malcolm N. Shaw. 2008. International Law Sixth Edition. New York: Cambridge University Press.

Malgosia Fitzmaurice Matthew dan Maria Vogiatzi. 2007. Time, History and International Law. Leiden: Martinus Nijhoff Publishers. 
Miriam Budiardjo. 2010. Dasar-Dasar IImu Politik: Edisi Revisi. Jakarta: Gramedia Pustaka Utama.

Mochtar Kusumaatmadja dan Etty R. Agoes. 2015. Pengantar Hukum Internasional. Bandung: Pusat Studi Wawasan Nusantara, Hukum dan Pembangunan dan PT. Alumni.

Mohd. Burhan Tsani. 1990. Hukum dan Hubungan Internasional. Yogyakarta: PAU- Studi Sosial UGM.

Muhammad Abu Zahrah. 1973. Hubungan-Hubungan Internasional dalam Islam. Jakarta: Penerbit Bulan Bintang.

Padmo Wahjono. 1982. Konsep Yuridis Negara Hukum Republik Indonesia. Jakarta: Rajawali.

Philipus M. Hadjon. 1987. Perlindungan Hukum Bagi Rakyat di Indonesia. Surabaya: Bina IImu

Pranoto Iskandar (ed.) .2011. Standar Internasional Migrasi Ketenagakerjaan Berbasis HAM. Cianjur: IMR Press

Pranoto Iskandar. 2013. Hukum HAM Internasional: Suatu Pengantar Kontekstual. Cianjur, IMR Press.

Rachmat Trijono. 2013. Dasar-Dasar IImu Pengetahuan PerundangUndangan. Jakarta: Penerbit Papas Sinar Sinanti.

Riant Nugroho. 2012. Public Policy. Jakarta: PT. Elex Media Komputindo.

Riant Nugroho. 2014. Metode Penelitian Kebijakan. Yogyakarta: Pustaka Pelajar.

Riant Nugroho 2014. Kebijakan Publik di Negara-negara Berkembang. Yogyakarta: Pustaka Pelajar.

Robert Jackson dan Georg Sorensen. 2009. Pengantar Studi Hubungan Internasional. Yogyakarta: Pustaka Pelajar.

Said Sampara dan La Ode Husen. 2016. Metode Penelitian Hukum Edisi Revisi. Makassar: Kretakupa Print.

Samantha Besson dan John Tasioulas (ed.). 2010. The Philosophy of International Law. New York: Oxford University Press. 
Samodra Wibawa. 2011. Politik Perumusan Kebijakan Publik. Yogyakarta: Graha IImu.

Sefriani. 2010. Hukum Internasional: Suatu Pengantar. Jakarta: Rajagrafindo Persada.

Sefriani. 2016. Peran Hukum Internasional dalam Hubungan Internasional Kontemporer. Jakarta: Rajagrafindo Persada.

Sirajuddin dan Winardi. 2015. Dasar-Dasar Hukum Tata Negara Indonesia. Malang: Setara Press.

Solahuddin Kusumanegara. 2010. Model dan Aktor dalam Proses Kebijakan Publik. Yogyakarta, Gava Media.

Syamsuddin Pasamai. 2013. Sejarah dan Sejarah Hukum dalam Perspektif Ilmu Hukum. Makassar: Arus Timur.

Takdir Ali Mukti. 2013. Paradiplomacy: Kerjasama Luar Negeri oleh Pemda di Indonesia. Yogyakarta: The Phinisi Press.

Theodor Meron. 2006. The Humanization of International Law. Leiden: Martinus Nijhoff Publishers.

Ulber Silalahi. 2012. Metode Penelitian Sosial. Bandung: PT. Refika Aditama.

Zaeni Asyhadie. 2007. Hukum Kerja: Hukum Ketenagakerjaan Bidang Hubungan Kerja. Jakarta: PT. RajaGrafindo Persada.

\section{Dokumen/Laporan}

\section{Hukum Nasional}

Undang-Undang Dasar Negara Republik Indonesia Tahun 1945

Kitab Undang-Undang Hukum Pidana

Kitab Undang-Undang Hukum Perdata

UU No. 37 Tahun 1999 tentang Hubungan Luar Negeri

UU No. 39 Tahun 1999 tentang Hak Asasi Manusia

UU No. 21 Tahun 2000 tentang Serikat Pekerja

UU No. 24 Tahun 2000 tentang Perjanjian Internasional

UU No. 13 Tahun 2003 tentang Ketenagakerjaan 
UU No. 23 Tahun 2004 tentang Penghapusan Kekerasan dalam Rumah Tangga

UU No. 39 Tahun 2004 tentang Penempatan dan Perlindungan Tenaga Kerja Indonesia di Luar Negeri

UU No. 40 Tahun 2004 tentang Sistem Jaminan Sosial Nasional

UU No. 21 Tahun 2007 tentang Pemberantasan Tindak Pidana Perdagangan Orang

UU No. 11 Tahun 2009 tentang Kesejahteraan Sosial

UU No. 6 Tahun 2011 tentang Keimigrasian

UU No. 24 Tahun 2011 tentang Badan Penyelenggara Jaminan Sosial

UU No. 31 Tahun 2014 tentang Perlindungan Saksi dan Korban

UU No. 40 Tahun 2014 tentang Perasuransian

UU No. 23 Tahun 2014 tentang Pemerintahan Daerah

Peraturan Pemerintah No. 3 Tahun 2013 tentang Perlindungan Tenaga Kerja Indonesia di Luar Negeri

Permenaker No. 22 Tahun 2014 tentang Pelaksanaan Penempatan Dan Perlindungan Tenaga Kerja Indonesia di Luar Negeri

Permenaker No. 23 Tahun 2014 tentang Tata Cara Kepulangan Tenaga Kerja Indonesia Dari Negara Penempatan Ke Daerah Asal Secara Mandiri

Permenaker No. 24 Tahun 2014 tentang Tata Cara Pemberian, Perpanjangan Dan Pencabutan Surat Izin Pelaksana Penempatan Tenaga Kerja Indonesia

UU No. 1 Tahun 1982 tentang Pengesahan Konvensi Wina mengenai Hubungan Diplomatik Beserta Protokol Opsionalnya Mengenai Hal Memperoleh Kewarganegaraan (Vienna Convention on Diplomatic Relations and Optional Protocol to the Vienna Convention on Diplomatic Relations Concerning Acquisition of Nationality, 1961) dan Pengesahan Konvensi Wina mengenai Hubungan Konsuler Beserta Protokol Opsionalnya Mengenai Hal Memperoleh Kewarganegaraan (Vienna Convention on Consular Relations and Optional Protocol to the Vienna Convention on Consular Relation Concerning Acquisition of Nationality, 1963) 
UU No. 17 Tahun 1984 tentang Pengesahan Konvensi mengenai Penghapusan Segala Bentuk Diskriminasi terhadap Wanita (Convention on the Ellimination of All Forms of Discrimination Against Women)

UU No. 5 Tahun 1998 tentang Pengesahan Konvensi menentang Penyiksaan dan Perlakuan atau Penghukuman Lain yang Kejam, Tidak Manusiawi atau Merendahkan Martabat Manusia (Convention against Torture and Other Cruel, Inhuman or Degrading Treatment or Punishment)

UU No.19 Tahun 1999 tentang Pengesahan Konvensi ILO mengenai Penghapusan Kerja Paksa (ILO Convention No. 105 Concerning the Abolition of Forced Labour)

UU No. 20 Tahun 1999 tentang Pengesahan Konvensi ILO mengenai Usia Minimum untuk Diperbolehkan Bekerja (ILO Convention No. 138 Concerning Minimum Age for Admission to Employment)

UU No. 21 Tahun 1999 tentang Pengesahan Konvensi ILO mengenai Diskriminasi dalam Pekerjaan dan Jabatan (ILO Convention No. 111 Concerning Discrimination in Respect of Employment and Occupation)

UU No. 11 Tahun 2005 tentang Pengesahan Konvenan Internasional tentang Hak-Hak Ekonomi, Sosial dan Budaya (International Convenant on Economic, Social and Cultural Rights)

UU No. 12 Tahun 2005 tentang Pengesahan Konvenan Internasional tentang Hak-Hak Sipil dan Politik (International Convenant on Civil and Political Rights)

UU No. 14 Tahun 2009 tentang Pengesahan Protokol untuk Mencegah, Menindak, dan Menghukum Perdagangan Orang, Terutama Perempuan dan Anak-Anak, Melengkapi Konvensi Perserikatan Bangsa-Bangsa Menentang Tindak Pidana Transnasional Yang Terorganisasi (Protocol To Prevent, Suppress And Punish Trafficking In Persons, Especially Women And Children, Supplementing The United Nations Convention Against Transnational Organized Crime)

UU No. 15 Tahun 2009 tentang Pengesahan Protokol untuk Menentang Penyelundupan Migran Melalui Darat, Laut, Dan Udara, Melengkapi Konvensi Perserikatan Bangsa-Bangsa Menentang Tindak Pidana Transnasional Yang Terorganisasi (Protocol Against The Smuggling of Migrants by Land, Sea and Air, Supplementing the United Nations Convention Against Transnational Organized Crime)

UU No. 6 Tahun 2012 Pengesahan Konvensi Internasional mengenai Perlindungan Hak-hak Seluruh Pekerja Migran dan Anggota Keluarganya (International Convention on the Protection of the Rights of All Migrant Workers and Members of Their Families) 
Dewan Perwakilan Rakyat Republik Indonesia. (2012). Undang-Undang No. 6 Tahun $2012 \quad$ - $\quad$ http://www.dpr.go.id/id/undangundang/2012/6/uu/PENGESAHAN-INTERNATIONAL-CONVENTION-ONTHE-PROTECTION-OF-THE-RIGHTS-OF-ALL-MIGRANT-WORKERSAND-MEMBERS-OF-THEIR-FAMILIES-KONVENSI-INTERNASIONALMENGENAI-PERLINDUNGAN-HAK-HAK-SELURUH-PEKERJAMIGRAN-DAN-ANGGOTA-KELUARGANYA

\title{
Lembaga Pemerintah
}

Bank Indonesia. (2009). Laporan Survei Nasional Pola Remitansi TKI Tahun 2008. Jakarta: Bank Indonesia.

\author{
BNP2TKI, (2016), Data Penempatan dan Perlindungan Tenaga Kerja \\ Indonesia Periode 1 Januari-30 November 2016 \\ http://www.bnp2tki.go.id/uploads/data/data_09-12- \\ 2016_110656_Laporan_Pengolahan_Data_BNP2TKI_S.D_November_20 \\ 16_.pdf.
}

Dewan Perwakilan Rakyat Republik Indonesia, (2012), Risalah Rapat Kerja Komisi IX pada Pembicaraan Tingkat I Pembahasan RUU tentang Pengesahan Konvensi Internasional mengenai Perlindungan Hak-Hak Seluruh Pekerja Migran dan Anggota Keluarganya. WikiDPR, 2016, Penyerahan DIM RUU PPILN Kepada DPR: Rapat Kerja Komisi 9 dengan Pemerintah - http://wikidpr.org/rangkuman/penyerahan-dim-ruuppiln-kepada-dpr---rapat-kerja-komisi-9-dengan-pemerintah, diakses pada 5 Juni 2017.

Naskah Akademik Rancangan Undang-Undang Perlindungan Pekerja Indonesia di Luar Negeri (RUU PPILN), 27 Mei 2015. Diunduh dari http://wikidpr.org/uploads/ruu/56a7b0390d00db504b000027/naskah-akademikruu-perlindungan-tenaga-kerja-di-luar-negeri-27-mei-2015.pdf, tanggal 3 Juni 2017.

WikiDPR. 2015. RUU Perlindungan TKI di Luar Negeri - Rapat Komisi 9 dengan Deputi Perundang-Undangan DPR-RI http://wikidpr.org/rangkuman/ruu-perlindungan-tki-di-luar-negeri---rapatkomisi-9-dengan-deputi-perundang-undangan-dpr-ri, diakses pada 5 Juni 2017.

WikiDPR. 2015. Penyerahan Hasil Panja RUU PPILN - Komisi 9 $\begin{array}{llll}\text { Mengadakan Rapat Panja RU PPILN } & \end{array}$ http://wikidpr.org/rangkuman/penyerahan-hasil-panja-ruu-ppiln-komisi-9mengadakan-rapat-panja-ruu-ppiln, diakses pada 5 Juni 2017.

WikiDPR. 2016. Penyerahan DIM RUU PPILN Kepada DPR: Rapat Kerja Komisi 9 dengan Pemerintah 
http://wikidpr.org/rangkuman/penyerahan-dim-ruu-ppiln-kepada-dpr--rapat-kerja-komisi-9-dengan-pemerintah, diakses pada 5 Juni 2017.

\section{Lembaga Swadaya Masyarakat dan Organisasi Internasional}

Human Right Watch. 2012. DPR Setujui Konvensi Buruh Migran http://www.hrw.org/id/news/2012/04/12/dpr-setujui-konvensi-buruh-migran, diakses pada 20 Desember 2016.

International Labour Organization. 2013. Laporan ILO: 10 Tahun Menangani Migrasi Kerja di Indonesia http://www.ilo.org/wcmsp5/groups/public/---asia/---ro-bangkok/---ilojakarta/documents/publication/wcms_213360.pdf.

International Organization for Migration. 2010. Migrasi Tenaga Kerja dari Indonesia: Gambaran Umum Migrasi Tenaga Kerja Indonesia di Beberapa Negara Tujuan di Asia dan Timur Tengah. Jakarta: IOM.

Serikat Buruh Migran Indonesia. 2015. Rilis JBM: Menagih Komitmen Harmonisasi Konvensi Migran - http://sbmi.or.id/2015/12/rilis-jbm-menagihkomitmen-harmonisasi-konvensi-migran/, diakses 5 Juni 2017.

United Nations. 2016. New York Declarations - UN Summit for

Refugees and Migrants - http://refugeesmigrants.un.org/declaration, diakses pada 19 Desember 2016.

United Nations Educational, Scientific, and Cultural Organization. 2003. United Nations Convention on Migrants' Rights. New York: UNESCO.

United Nations Human Rights. 1990. International Convention on the Protection of the Rights of All Migrant Workers and Members of Their Families -http://www.ohchr.org/EN/Professionallnterest/Pages/CMW.aspx

United Nations Treaty Collection. 2003. International Convention on the Protection of the Rights of All Migrant Workers and Members of their Families- http://treaties.un.org/Pages/ViewDetails.aspx?mtdsg_no=IV13\&chapter $=4 \&$ lang $=$ en

\section{Karya Tulis IImiah}

Achmad Zulfikar, Suleman, dan Aan Febriadi. (2013). Penguatan Kapasitas Tenaga Kerja Internasional Indonesia dalam Aspek Etika dan Hukum di Kalangan Penyalur Jasa TKI di Yogyakarta. Program Kreativitas Mahasiswa-Penelitian Didanai DIKTI Tahun 2013, Universitas Muhammadiyah Yogyakarta. (http://doi.org/10.31227/osf.io/vyb4k) 
Achmad Zulfikar. 2013. Alasan Pemerintah Indonesia Meratifikasi Konvensi Internasional Perlindungan Hak Pekerja Migran Tahun 2012. Skripsi. Universitas Muhammadiyah Yogyakarta. (http://doi.org/10.31237/osf.io/78tdu)

Achmad Zulfikar. 2014. Indonesian Migrant Workers Protection Abroad: Indonesian Law Post-Ratification of International Convention on Migrant Workers. Juris Gentium Law Review Vol. 2 No. 1 September 2014, hh. 30-41. (http://doi.org/10.31227/osf.io/8uf5b)

Achmad Zulfikar. 2015. Rasionalitas Ekonomi Politik dalam Ratifikasi Konvensi Internasional Perlindungan Hak Pekerja Migran Tahun 2012. The Politics: Jurnal Magister IImu Politik Universitas Hasanuddin Vol. 1 No. 1 Januari 2015. Makassar: Magister IImu Politik Universitas Hasanuddin. hh. 37-49.

(http://journal.unhas.ac.id/index.php/politics/article/view/128)

Akbar Kurnia Putra. 2015. Harmonisasi Konvensi Cyber Crime dalam Hukum Nasional. Jurnal Ilmu Hukum Vol. 5 No. 2 Tahun 2014. hh. 95109. (http://online-journal.unja.ac.id/index.php/jih/article/view/1953)

Aspiannor Masrie. 2015. Analisis Kebijakan Susilo Bambang Yudhoyono dalam Menangani Masalah Tenaga Kerja Indonesia di Malaysia dalam Perspektif Ekonomi Politik. Tesis. Universitas Hasanuddin.

Desi Auliani Hasibuan. 2011. Kebijakan Politik Pemerintah Susilo Bambang Yudhoyono Mengenai Hak Asasi Manusia (HAM) Tahun 2004-2009 (Studi Analisis Mengenai TKI yang Bekerja di Malaysia). Skripsi, Universitas Sumatera Utara.

Endang Saefullah Wiradipradja. 2003. Prinsip-Prinsip Hukum Internasional dalam Islam. Mimbar: Jurnal Sosial dan Pembangunan Volume XIX No. 2 April-Juni 2003. hh. 118-134. (http://ejournal.unisba.ac.id/index.php/mimbar/article/view/96).

Indah Susilowati, Mudji Rahardjo dan Waridin. 2001. Analisis Masalah Sosial, Politik dan Ekonomi pada Migrasi Tenaga Kerja Indonesia ke Luar Negeri. Laporan Penelitian DCRG. Universitas Diponegoro.

Faizah Khotimatul Husna. 2013. Kajian Kebijakan Pemerintah dalam Penempatan dan Perlindungan Tenaga Kerja Indonesia. Tesis. Universitas Gadjah Mada.

Kardina. 2015. Pelanggaran Malaysia terhadap Standar HAM Convention on the Elimination of All Forms of Discrimination Against Women dalam Isu Kekerasan Migrant Domestic Worker Indonesia. Tesis. Universitas Gadjah Mada. 
Muhammad Nasir Badu (ed.). 2015. Proceeding of International Seminar Democracy and Election: Solution for Establishing Good Governance. Yogyakarta: LeutikaBooks.

Natasha Karina Ardiani. 2009. Penyebab Indonesia Belum Meratifikasi Konvensi PBB Tahun 1990 tentang Perlindungan Hak Buruh Migran dan Keluarganya. Skripsi, Prodi Hubungan Internasional Universitas Airlangga, Surabaya.

Natasha Karina Ardiani. 2009. Ratification of UN Convention on Migrant Workers (1990): The Case of Indonesia and The Philippines. Indonesian Journal of Social Sciences Vol. 1 No. 32009. (http://journal.unair.ac.id/ratification-of-un-convention-on-migrant-workers(1990)-the-case-of-indonesia-and-the-philippines-article-3100-media-35category-8.html).

Nur Angga Ardiyanto. 2013. Kajian Migrasi dan Penghidupan Tenaga Kerja asal Indonesia di Kampung Pandan dalam Ampang Jaya Malaysia. Skripsi. Universitas Gadjah Mada.

Mosgan Situmorang. 2014. Harmonisasi Hukum Nasional di Bidang Korupsi dengan United Nations Convention Against Corruption. Jurnal RechtsVinding: Media Pembinaan Hukum Nasional Vol. 3 No. 3 Desember $2014 . \quad$ hh. 329-346. (http://rechtsvinding.bphn.go.id/view/?id=179\&isi=artikel)

Suhartono. 2011. Harmonisasi Peraturan Perundang-Undangan dalam Pelaksanaan Anggaran Belanja Negara. Disertasi. Depok: Fakultas Hukum Universitas Indonesia.

Wacipto Setiadi. 2007. Proses Pengharmonisasian sebagai Upaya untuk Memperbaiki Kualitas Peraturan Perundang-Undangan. Jurnal Legislatif Indonesia Vol. 4 No. 2 Juni 2007.

\section{Media Massa}

Antara News. 2013. Kemlu bentuk 11 Kelompok Kerja Kongres Diaspora - http://www.antaranews.com/berita/384634/kemlu-bentuk-11kelompok-kerja-kongres-diaspora, diakses pada 19 Desember 2016.

Hukum Online. 2013. RUU PPTKLN Masih Abaikan Perlindungan TKI http://www.hukumonline.com/berita/baca/t512c88d35a24e/ruupptklnmasih abaikanperlindungantki, diakses 3 Juni 2017.

Hukum Online. 2016. RUU PPILN Adopsi Konvensi PBB 1990 http://www.hukumonline.com/berita/baca/t56dd4946500d5/ruu-ppilnadopsi-konvensi-pbb-1990, diakses pada 5 Juni 2017. 
Kamus Besar Bahasa Indonesia Online, Harmoni http://kbbi.web.id/harmoni, diakses 20 Desember 2016. 